IZABELA GOŁĘBIOWSKA

\title{
Użyteczność geowizualizacji wieloelementowych w kontekście semiotyki kartograficznej
}




\section{Użyteczność geowizualizacji wieloelementowych w kontekście semiotyki kartograficznej}





\section{IZABELA GOŁĘBIOWSKA}

\section{Użyteczność geowizualizacji wieloelementowych w kontekście semiotyki kartograficznej}


Recenzenci

dr hab. Beata Konopska, prof. UMCS

dr hab. Wiesława Żyszkowska, prof. emeryt. UWr

Redaktor prowadzący

Małgorzata Yamazaki

Redakcja

Małgorzata Nowak

Redakcja techniczna

Maryla Broda

Korekta

Elżbieta Szwedo

Indeks

Henryk Nazarewicz

Projekt okładki i stron tytułowych

Anna Zagrajek

Skład i łamanie

Marcin Szcześniak

Badanie finansowane przez Narodowe Centrum Nauki w ramach projektu numer UMO-2018/31/D/HS6/02770, pt. „Optymalizacja redakcji legendy mapy jako elementu narzędzi geowizualizacji w kontekście efektywności i strategii pozyskiwania informacji”, a także przez The Research Council of Norway, projekt numer 227305/F11.

(C) Copyright by Wydawnictwa Uniwersytetu Warszawskiego, Warszawa 2021

Izabela Gołębiowska ORCID 0000-0002-4307-7054

Uniwersytet Warszawski

ISBN 978-83-235-5333-5 (druk) ISBN 978-83-235-5341-0 (pdf online)

ISBN 978-83-235-5349-6 (e-pub) ISBN 978-83-235-5357-1 (mobi)

Wydawnictwa Uniwersytetu Warszawskiego

00-838 Warszawa, ul. Prosta 69

e-mail:wuw@uw.edu.pl

księgarnia internetowa: www.wuw.pl

Wydanie 1, Warszawa 2021

Druk i oprawa: Totem.com.pl 


\section{Spis treści}

Wprowadzenie

1. Kartografia, geowizualizacja, GIScience - dyscypliny i współczesne

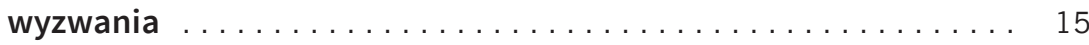

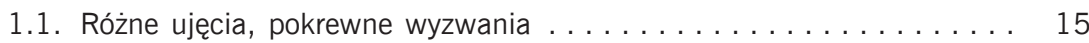

1.2. Oczekiwania wobec współczesnych opracowań kartograficznych . . . 21

1.3. Semiotyka kartograficzna . . . . . . . . . . . . . . . . . 24

1.4. Semiotyka kartograficzna a geowizualizacje wieloelementowe . . . . . 28

2. Geowizualizacje wieloelementowe . . . . . . . . . . . . . . . 29

2.1. Idea geowizualizacji wieloelementowych . . . . . . . . . . . 29

2.2. Geowizualizacje wieloelementowe jako opracowanie wiralowe . . . . . 36

2.3. Potrzeba badań użyteczności geowizualizacji wieloelementowych . . . . 37

2.4. Zagadnienia podejmowane $w$ dotychczasowych badaniach empirycznych geowizualizacji wieloelementowych . . . . . . . . . . . . 40

2.5. Redundancja w kontekście geowizualizacji wieloelementowych . . . . . 44

2.5.1. Definicja i poglądy na redundancję . . . . . . . . . . . 44

2.5.2. Redundancja a nieprzystępne formy prezentacji treści. . . . . . . 51

2.6. Przystępność geowizualizacji wieloelementowej dla niedoświadczonych

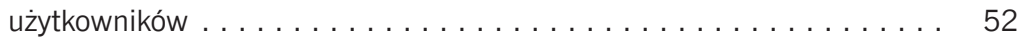

2.6.1. Potrzeba wsparcia nowych użytkowników . . . . . . . . 52

2.6.2. Formy materiałów szkoleniowych dla nowych użytkowników . . . 53

3. Badania użyteczności opracowań kartograficznych z wykorzysta-

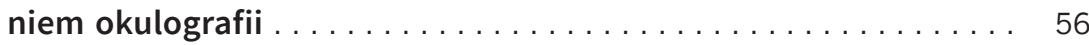

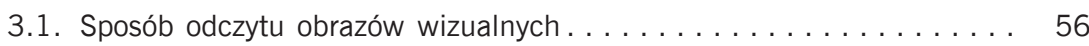

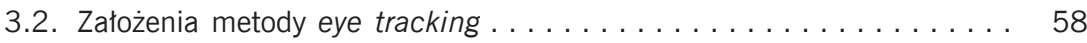

3.3. Zastosowanie metody eye tracking w kartografii i geowizualizacji ... 64

4. Empiryczna weryfikacja rozważań teoretyczno-koncepcyjnych . . 67

4.1. Testowane wieloelementowe narzędzie geowizualizacji . . . . . . . 70

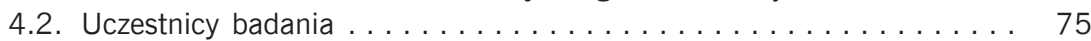

4.3. Zadania ........................... 76

4.4. Przyjęte metody badawcze . . . . . . . . . . . . . . . . . 79

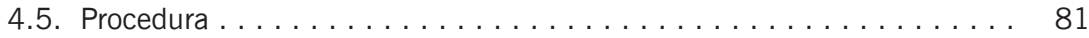

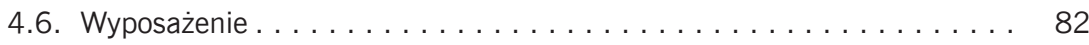

4.7. Analiza danych $\ldots \ldots \ldots \ldots \ldots \ldots \ldots \ldots \ldots \ldots \ldots \ldots$ 


\section{Wyniki}

5.1. Sposób poznawania nieznanego wieloelementowego narzędzia geowizu-

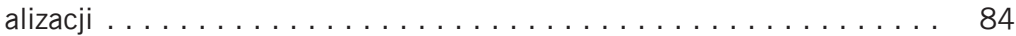

5.1.1. Uwaga wizualna $w$ trakcie dowolnej eksploracji. . . . . . . . . 84

5.1.2. Wykorzystanie funkcji interaktywnych . . . . . . . . . 88

5.1.3. Komentarze uczestników badania . . . . . . . . . . . . . . 90

5.2. Sposób pozyskiwania informacji z narzędzia cechującego się redundancją

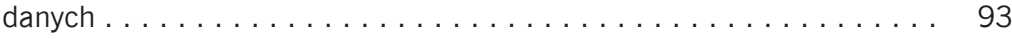

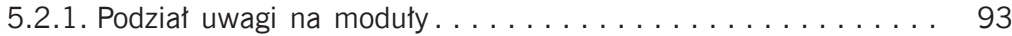

5.2.2. Strategie rozwiązywania zadania . . . . . . . . . . . . . 97

5.2.3. Kluczowe etapy rozwiązywania zadania . . . . . . . . . . . 101

5.2.4. Poprawność odpowiedzi . . . . . . . . . . . . . . . . . 103

6. Dyskusja wyników . . . . . . . . . . . . . . . . . . 106

6.1. Sposób pracy z nieznanym wieloelementowym narzędziem geowizuali-

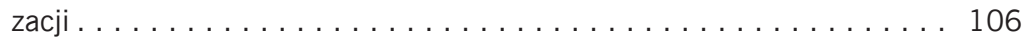

6.1.1. Elementy pomocne $\mathrm{w}$ nauce nieznanego wieloelementowego narzędzia geowizualizacji . . . . . . . . . . . . . . 107

6.1.2. Elementy przyciągające uwagę $w$ trakcie poznawania wieloelementowego narzędzia geowizualizacji . . . . . . . . . 108

6.1.3. Chętnie wykorzystywane funkcje interaktywne . . . . . . . 108

6.1.4. Wskazówki w trakcie projektowania materiałów szkoleniowych. . 109

6.2. Część testowa . . . . . . . . . . . . . . . . . . . . . 111

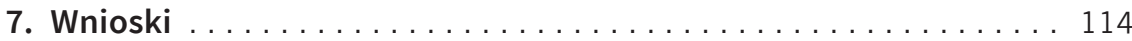

7.1. Semiotyka kartograficzna jako podstawa formułowania wniosków. . . . 114

7.2 Możliwości metody eye tracking w kontekście badań geowizualizacji

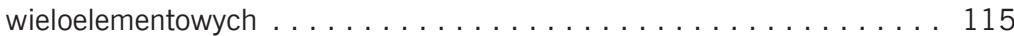

7.3. Złożoność legendy geowizualizacji wieloelementowych . . . . . . . 117

7.3.1. Dwa wymiary geowizualizacji . . . . . . . . . . . . 117

7.3.2. Poznawanie geowizualizacji wieloelementowej . . . . . . . . 119

7.3.3. Legenda geowizualizacji wieloelementowych . . . . . . . . . . 120

7.4. Konsekwencje uwzględnienia złożoności legendy geowizualizacji wieloelementowych . . . . . . . . . . . . . . . . . . . . . 123

8. Podsumowanie . . . . . . . . . . . . . . . . . . . . . 126

Literatura . . . . . . . . . . . . . . . . . . . . . . . . . . . 129

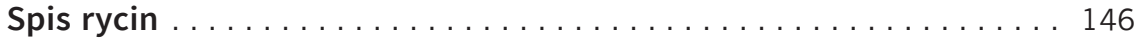

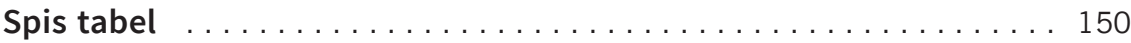

Summary . . . . . . . . . . 151

Indeks nazwisk . . . . . . . . . . . . . . . . . . . . . 154 


\section{Wprowadzenie}

Kartografia, jako dyscyplina naukowa oraz działalność praktyczna, podlega od kilku dekad intensywnym zmianom za sprawą dynamicznego rozwoju technologicznego. Dzięki technologii, a zatem nowym mediom i środkom wyrazu, pojawiają się możliwości, a wraz z nimi - problemy i wyzwania. Przykładem rozwiązania, będącego konsekwencją nowych możliwości technologicznych i nowego sposobu podejścia do pracy z informacją przestrzenną, są geowizualizacje wieloelementowe (ang. coordinated and multiple views, CMV). Składają się one z kilku modułów (okien, paneli), widocznych jednocześnie i połączonych ze sobą interaktywnie, przez co prezentują dane przestrzenne za pomocą różnych form, w tym map (Roberts 2007). Takie opracowania uznawane są przez niektórych autorów za jedne z bardziej obiecujących rozwiązań geowizualizacji (Koua, MacEachren i Kraak 2006), choć pojawiały się również opinie o ich niewielkiej użyteczności (Andrienko i Andrienko 2007). Ich zaletą jest możliwość prezentacji dużych ilości danych, które użytkownik może interaktywnie eksplorować $w$ dogodny dla siebie sposób.

Warto jednak zauważyć, że sama idea łączenia różnych środków wyrazu z mapą - choć z mapą w formie statycznej i papierowej - nie jest rozwiązaniem nowym. Stosuje się je obecnie i stosowano w przeszłości (ryc. 1), de facto od kilku stuleci. Mapa statyczna łączona jest często z innymi formami na różne sposoby i w rozmaitych konfiguracjach. Zakres rozwiązań obejmuje między innymi takie, jak:

- tekst jako uzupełnienie mapy, na przykład jako komentarz do mapy geologicznej,

- mapa jako uzupełnienie tekstu, na przykład w przewodniku turystycznym,

- mapa i wykres, których treści się wzajemnie uzupełniają, na przykład na arkuszu w atlasie (ryc. 1). 


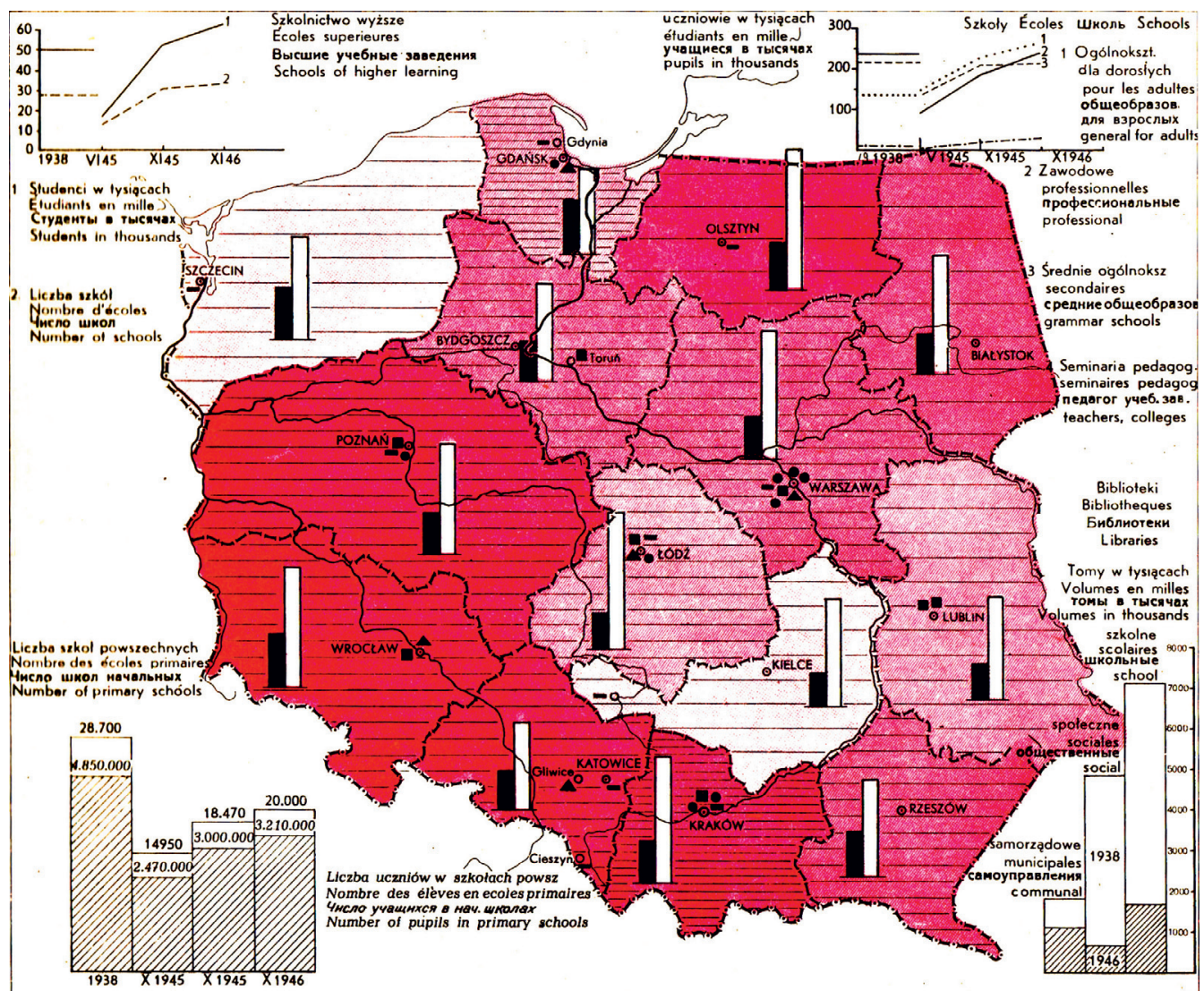

Rycina 1. Przykład zastosowania różnych form prezentacji danych na jednym arkuszu atlasowym z roku 1947 (zmniejszenie do 80\% oryginału)

Źródło: J. Kondracki (1947)

Łączenie form prezentacji jest często spotykane również w atlasach narodowych i tematycznych, w których obok map często umieszcza się diagramy, fotografie i tekst. Jest to jedna z tendencji wyróżnionych przez W. Ostrowskiego i J. Ostrowskiego (2014) na podstawie analizy wybranych atlasów państw europejskich. Jak zauważają autorzy, te dodatkowe elementy, niewątpliwe wzbogacające treść atlasów, są istotnym i poglądowym uzupełnieniem map.

Mapa stanowi bowiem jeden ze sposobów prezentacji danych i w związku z tym na gruncie semiotyki stawiana jest obok innych konstrukcji graficznych (Bertin 1983). Każda z tych konstrukcji pełni inne funkcje i cechuje się innymi walorami. W kontekście prezentacji danych przestrzennych, w takim zestawieniu, mapa - o specyficznych cechach 
i możliwościach niedostępnych dla wielu innych form - pełni ważną, często pierwszoplanową funkcję. Już w latach 70. XX wieku W. Ostrowski (1970), precyzując zadania metakartografii jako gałęzi nauki, porównywał mapę z innymi rodzajami przekazu informacji w celu poszukiwania optymalnych sposobów prezentacji związków i układów przestrzennych. Opracowania kartograficzne nie są bowiem postrzegane jako jednolita forma, na przykład jedynie w postaci klasycznych map. A.M. Berlant (1993a; 1993b; 2000), proponując dziedzinę geoikoniki i koncepcję geoprzedstawień (a później hipergeoprzedstawień), zwrócił uwagę na różnorodność form prezentacji informacji przestrzennej. Ujęcie to było z powodzeniem kontynuowane przez Z. Kozieła (2001; 2003; 2014a), który jako geokompozycję określił kompozycje multimedialne, obejmujące ujęcia graficzne, dźwiękowe czy wideo odnoszące się do powierzchni Ziemi i całej geosfery. Autor wskazał na zalety geokompozycji polimorficznych (obejmujących różne formy). Ponadto zauważył, że jest to prezentacja, która może przyczynić się do ukazania rangi map. Podejście takie widoczne jest również w multisensorycznych opracowaniach, które mają łączyć różne kanały sensoryczne, np. wizualne, słuchowe, dotykowe (Konopska i Kamiński 2020). Przykładem tego jest przedstawiony przez B. Konopską i M. Kamińskiego (2020) mobilny przewodnik w formie aplikacji.

Zróżnicowanie środków wyrazu w postaci multimediów było i jest postrzegane jako rozwiązanie o dużym potencjale dla rozwoju map i kartografii w ogóle. Zwrócili na to uwagę A. Czerny i współautorzy (1999), wskazując, że technologia multimedialna umożliwia łączenie map z innymi środkami przekazu (np. tekstem, tabelą, wykresami, zdjęciami lotniczymi, dźwiękiem), zarówno statycznymi, jak i dynamicznymi. Mapa funkcjonuje w takich opracowaniach jako część składowa systemu multimedialnego. Zainteresowanie potencjałem tego typu opracowań miało odbicie na przykład w tytule XXXVII Ogólnopolskiej Konferencji Kartograficznej „Kartografia w multimediach. Multimedia w kartografii” (Kozieł 2014b) czy w tytule tomu tematycznego "Multimedia Cartography” czasopisma naukowego "ISPRS International Journal of Geo-Information” (2021).

Geowizualizacje wieloelementowe, łączące różne formy prezentacji, w tym mapy, mogą być zatem postrzegane jako ulepszenie i ułatwienie technologiczne wcześniej znanych rozwiązań stosowanych w węższej formie, ale jednocześnie jest to nowy typ opracowań o dużych możliwościach i nowych problemach redakcyjnych. Wprowadzenie interaktywności, czyli funkcji interaktywnych, pozwalające na oddziaływanie użytkownika na mapę, m.in. na jej wygląd oraz zakres treści, w takich zestawieniach form prezentacji daje nowe możliwości, ale również przynosi wyzwania. 
Interaktywność przyczynia się do zmiany sposobu pracy z tego typu opracowaniami, oferując nowe podejście do analizy i poznawania przez użytkownika prezentowanych danych. Geowizualizacje wieloelementowe posiadają duży potencjał dla efektywnej eksploracji dużych i złożonych zestawów danych, jednak jak każde nowe opracowanie potrzebują one stosownej oceny. Wskazywany był między innymi problem ich ograniczonego zastosowania (Andrienko i Andrienko 2007), zatem zrozumienie, w jaki sposób użytkownicy uczą się tego typu opracowań i jak można im w tym pomóc, wydaje się kluczowe dla ich spopularyzowania.

Geowizualizacje wieloelementowe to kolejny przykład rozszerzania formy i funkcji mapy, od map statycznych, przez dynamiczne do interaktywnych. Tak więc obok map statycznych istnieją inne rozwiązania rozszerzające ujęcie mapy, a tym samym kartografii. Wśród nich można wymienić: mapy animowane - jako konsekwencję zastosowania zmiennych dynamicznych, mapy soniczne - wykorzystujące dźwięk, mapy interaktywne. Zestawienie mapy z innymi formami w interaktywnym kontekście, w postaci wieloelementowych geowizualizacji - to kolejny przejaw takiej ewolucji formy i funkcji mapy.

Stale zatem rozszerza się zakres zadań, jakie może spełniać mapa, i zakres kontekstów, w których jest ona stosowana. Powoduje to potrzebę określenia teoretycznych podstaw do poszerzenia katalogu zadań, ale również do uzasadnienia i oceny działań praktycznych w zakresie redakcji różnego typu opracowań kartograficznych, w tym geowizualizacji wieloelementowych. W dużej mierze dotychczasowe działania i wysiłki w odniesieniu do geowizualizacji wieloelementowych koncentrowały się na aspektach technologicznych (np. Robinson i współautorzy 2017a, Pezanowski i współautorzy 2018, Nazemi i Burkhardt 2019). Jak zauważył W. Ostrowski (1974a; 1998), specjalizacja dziedzin wiedzy przynosi jednocześnie tendencję do integracji nauk i przez to do jednorodnego rozpatrywania zagadnień podobnych do siebie. Wyrazem tego jest powstanie dyscyplin, w ramach których rozpatrywane są różne zjawiska pod kątem ich ogólnych aspektów funkcjonowania. Jako przykład takiej dyscypliny przywołuje między innymi semiotykę. Takie procesy można również dostrzec w ramach dyscypliny kartograficznej. Jednocześnie, jak zauważa autor, wykorzystanie w kartografii osiągnięć innych dziedzin wiedzy umożliwia opracowanie w jej ramach bardziej zwartego systemu, a także lepsze określenie stosunku kartografii do innych nauk.

Ogólna motywacja niniejszej pracy to odniesienie badań geowizualizacji wieloelementowych do semiotyki kartograficznej. Potrzebne jest do tego uzasadnienie i wskazanie adekwatności tej koncepcji teoretycznej do analizy i oceny opracowań geowizualizacji wieloelementowych. W świetle 
semiotyki wśród ważnych kwestii redakcyjnych można wskazać: dobór danych podlegających symbolizacji, tłumaczenie znaczenia znaków w legendzie, która szczególnie mieści się w obszarze zainteresowania semantyki, a także sposób poznania prezentacji i jej zrozumienia przez użytkowników, co stanowi przedmiot analiz ważnego działu semiotyki, jakim jest pragmatyka. Celem poznawczym pracy jest ocena przydatności redundancji w trakcie projektowania geowizualizacji wieloelementowej. Cel metodyczny opracowania to rozwinięcie metodyki okulografii (eye tracking) w zakresie analizy danych w badaniach wieloelementowych narzędzi geowizualizacji; zwłaszcza wskazanie nowych obszarów zastosowania metody eye tracking, a tym samym rozszerzenie potencjału metody. Jako cel utylitarny można wskazać określenie sposobu poznania i wykorzystania geowizualizacji wieloelementowych przez niedoświadczonych użytkowników i na tej podstawie - formułowanie wskazówek dla osób projektujących tego typu opracowania, jak i przygotowujących materiały szkoleniowe wprowadzające do pracy z geowizualizacjami wieloelementowymi.

Efektem pracy jest sformułowanie modelu poznawania geowizualizacji wieloelementowej, który stanowi podstawę do zaproponowania rozszerzonego spojrzenia na legendę tego typu opracowań poprzez rozbudowanie jej - obok tradycyjnie ujmowanej symbolizacji - również o wymiar interaktywności. Innym efektem pracy, osiągniętym między innymi w wyniku przeprowadzonych badań empirycznych, jest rozwinięcie metodyki eye tracking poprzez zaproponowanie nowego ujęcia analiz danych uzyskanych za pomocą tej metody. Ponadto, przeprowadzone badania empiryczne pozwalają na ocenę przydatności geowizualizacji wieloelementowych dla niedoświadczonych użytkowników oraz sformułowanie zaleceń dla projektantów tego typu opracowań. Autorzy wieloelementowych geowizualizacji w trakcie prac projektowych mają do wyboru wiele rozwiązań, które pozornie tylko mogą cechować się podobną użytecznością. Jak określiła C. Brewer (1997), „prace empiryczne i eksperymentalne są najbardziej wiarygodnym sposobem na zweryfikowanie potocznych przekonań" (s. 218).

W konsekwencji efekty i osiągnięte cele obejmują nie tylko uporządkowanie dotychczasowej wiedzy, ale też - dzięki osadzeniu jej na gruncie teoretycznym - zaproponowanie nowych ujęć o charakterze syntetycznym: modelu poznawania geowizualizacji wieloelementowych, legendy tego typu opracowań oraz analizy danych eye tracking $w$ trakcie badań opracowań interaktywnych.

Do realizacji wskazanych powyżej celów przeprowadzone zostały rozważania natury teoretycznej z zakresu kartografii i dyscyplin 
pokrewnych, sposobu ujęcia badań z użytkownikami opracowań z tego zakresu. Następnie przedstawiono badania empiryczne, które pozwoliły na sfomułowanie wniosków o charakterze zarówno praktycznym, jak i teoretycznym. Dzięki uwzględnieniu kontekstu semiotyki kartograficznej zostały sformułowane wnioski natury ogólnej, które pozwoliły na wyróżnienie płaszczyzn pomocnych w trakcie projektowania interfejsów geowizualizacji wieloelementowych.

Problematyka sposobu wykorzystania geowizualizacji wieloelementowych jest zagadnieniem badawczym znajdującym się w obszarze moich zainteresowań naukowych od około 2014 roku (Opach, Gołębiowska i Fabrikant 2014). Od początku moich działań badawczych koncentrujących się na geowizualizacjach wieloelementowych ważne dla mnie było zrozumienie roli legendy (Opach, Gołębiowska i Fabrikant 2014), co stanowiło kontynuację wcześniejszych zainteresowań badawczych w tym zakresie (Gołębiowska 2010; 2015). Poszerzyłam jednak obszar badań o problematykę przydatności redundancji (czyli powtórzenia treści) na mapach i w geowizualizacjach wieloelementowych (Gołębiowska, Opach i Rød 2017; Korycka-Skorupa i Gołębiowska 2020) oraz sposobu zrozumienia tych geowizualizacji przez nowych użytkowników (Gołębiowska, Opach i Rød 2020). W badaniach empirycznych prowadzonych przeze mnie w ostatnim okresie (np. Gołębiowska i Çöltekin 2020; Słomska-Przech i Gołębiowska 2021) wielokrotnie korzystałam z metody eye tracking, badając zarówno opracowania interaktywne, jak i mapy statyczne (Havelková i Gołębiowska 2019), dzięki czemu miałam możliwość poznania potencjału tej metody w odniesieniu do badań różnego typu opracowań kartograficznych.

W niniejszym opracowaniu koncentruję się na wybranych badaniach, które realizowane były $w$ ramach kierowanego przeze mnie projektu naukowego finansowanego przez Norwegian Research Council. Projekt obejmował między innymi przeprowadzenie badań empirycznych na Norweskim Uniwersytecie Nauki i Technologii w Trondheim. Wyniki tych badań rozwijane są dalej $w$ ramach kierowanego przeze mnie projektu finansowanego przez Narodowe Centrum Nauki. Część tych rozważań i wyniki badań empirycznych zostały opublikowane (Gołębiowska, Opach i Rød 2017; 2020), jednak badania prezentowane w niniejszym opracowaniu są osadzone w szerszym niż dotychczas kontekście zarówno samej dyscypliny kartograficznej, jak i dyscyplin pokrewnych (rozdziały 1-1.2), semiotyki kartograficznej (rozdziały 1.3-1.4), i konkretnych problemów o charakterze teoretycznym (rozdział 2.4). Również analiza danych została rozszerzona (rozdział 5). W formułowaniu wniosków i w interpretacji uzyskanych wyników wspierałam się ponadto wiedzą 
zebraną w trakcie innych powiązanych - tematycznie, problemowo lub metodycznie - badań empirycznych, które prowadziłam w ciągu ostatnich lat (np. Słomska-Przech i Gołębiowska 2020; Gołębiowska i Çöltekin 2020). Wszystko to stanowi podstawę do sformułowania nowych, bardziej ogólnych wniosków, przedstawionych w rozdziale 7 .

Praca zbudowana jest z ośmiu rozdziałów. W rozdziale otwierającym zarysowałam pozycję kartografii w kontekście kilku pokrewnych ujęć innych dyscyplin naukowych. Zaznaczyłam również rolę semiotyki w kartografii, a w szczególności zwróciłam uwagę na możliwości wykorzystania semiotyki kartograficznej w przygotowaniu i analizie wyników badania geowizualizacji wieloelementowych. W kolejnym rozdziale przybliżyłam pojęcie geowizualizacji wieloelementowych, a także wskazałam na problemy związane z ich projektowaniem. W rozdziale trzecim podjęłam temat potrzeby badań użyteczności w kartografii i geowizualizacji - ze szczególnym uwzględnieniem tych, które wykorzystują metodę eye tracking. Kolejne trzy rozdziały zawierają opis i analizę przeprowadzonych przeze mnie badań empirycznych, które miały na celu zweryfikowanie rozważań teoretycznych i udzielenie odpowiedzi na postawione pytania badawcze. W ich centrum postawiłam proces uczenia się nieznanego narzędzia wieloelementowego i przydatność redundancji w tego typu opracowaniach. Analizy te skierowały moją uwagę na semantykę kartograficzną. Ze względu na prowadzenie badań z użytkownikami geowizualizacji wieloelementowej, szczególne znaczenie ma ich pragmatyczny aspekt. Z kolei w rozdziale siódmym przedstawiłam wnioski sformułowane w nowym kontekście na podstawie uzyskanych wyników i analiz kartograficznych. Umożliwiło to zaprezentowanie rozszerzonego ujęcia legendy badanych geowizualizacji oraz zaproponowanie modelu poznawania geowizualizacji wieloelementowych. Pracę zamyka podsumowanie, w którym oceniam znaczenie kartografii jako dyscypliny $w$ badaniach geowizualizacji wieloelementowych, wskazując także na potrzebę dalszych badań. 



\section{Kartografia, geowizualizacja, GIScience - dyscypliny i współczesne wyzwania}

\subsection{Różne ujęcia, pokrewne wyzwania}

Kartografia to termin funkcjonujący w publikacjach od wieków, jednak sformułowanie definicji kartografii jako nauki i dziedziny działalności praktycznej człowieka, która byłaby przyjęta bez zastrzeżeń, było i nadal pozostaje wyzwaniem. Międzynarodowa Asocjacja Kartograficzna definiuje kartografię jako dyscyplinę, która zajmuje się sztuką, nauką i technologią redakcji i użytkowania map (Griffin, Robinson i Roth 2017). Formułowane były inne definicje, również na gruncie polskiej kartografii (np. Makowski 2005, Ostrowski i Pasławski 2006, Medyńska-Gulij 2021), które nierzadko funkcjonowały równolegle. Różnice między nimi wskazywały na kładzenie nacisku na inne aspekty i funkcje mapy, były również efektem innego czasu ich sformułowania, a także stojącego za nimi spojrzenia na kartografię jako naukę.

Sformułowanie pełnej definicji kartografii jest jeszcze trudniejsze obecnie, gdy dyscyplina ta podlega wpływom związanym z intensywnym rozwojem technologicznym, więc jej definicja naturalnie ewoluuje. Zmiany technologii dotyczą szeregu aspektów, które rzutują zarówno na charakter map, jak i sposób ich opracowania oraz użytkowania. Po pierwsze, jest to ogromna ilość dostępnych danych, rozmaitość ich rodzajów, ale również wielka ich dynamika i szybka dezaktualizacja. Po drugie, znacznie zmienia się technologia opracowania map: powstają oprogramowania o zwiększających się możliwościach, a także dostępności. Pociąga to za sobą zmianę roli, zakresu aktywności i oczekiwań użytkowników map. Zmiany te, mimo że stanowią wyzwanie dla kartografii, są jednocześnie powodem wzrostu rangi zarówno dyscypliny kartograficznej, jak i samych map w społeczeństwie informacyjnym (Gartner i Huang 2016).

Wraz z wyłonieniem się wyzwań związanych z dynamicznym rozwojem technologicznym pojawiły się koncepcje, które sytuują dyscyplinę 
kartograficzną w nowym kontekście. Termin „wizualizacja geograficzna”, lub w skrócie „geowizualizacja”, jest jednym z częściej wykorzystywanych. Przyjmuje się, że geowizualizacja jako dyscyplina funkcjonuje od 1995 roku (Andrienko i współautorzy 2016). Podejście to nawiązuje do wizualizacji naukowej (DiBiase 1990), czyli wykorzystania analizy wizualnej w badaniach naukowych. To, co odróżnia ją od kartografii w klasycznym ujęciu, to nacisk na eksplorację danych geograficznych, a następnie wnioskowanie na jej podstawie, które możliwe jest przez wykorzystanie interaktywności (Dykes, MacEachren i Kraak 2005; Çöltekin, Janetzko i Fabrikant 2018; Çöltekin, Griffin i Robinson 2021). Za szczególnie istotne uważa się procesy poznawania danych oraz konstruowania nowej wiedzy. Ważną cechą tego ujęcia jest zatarcie granic między opracowaniem a użytkowaniem mapy. Między innymi poprzez zastosowanie interaktywności użytkownik może modyfikować treść i zakres treści mapy, stając się jednocześnie jej redaktorem. Koncepcja ta rozszerza zatem funkcję mapy i sposób jej wykorzystania.

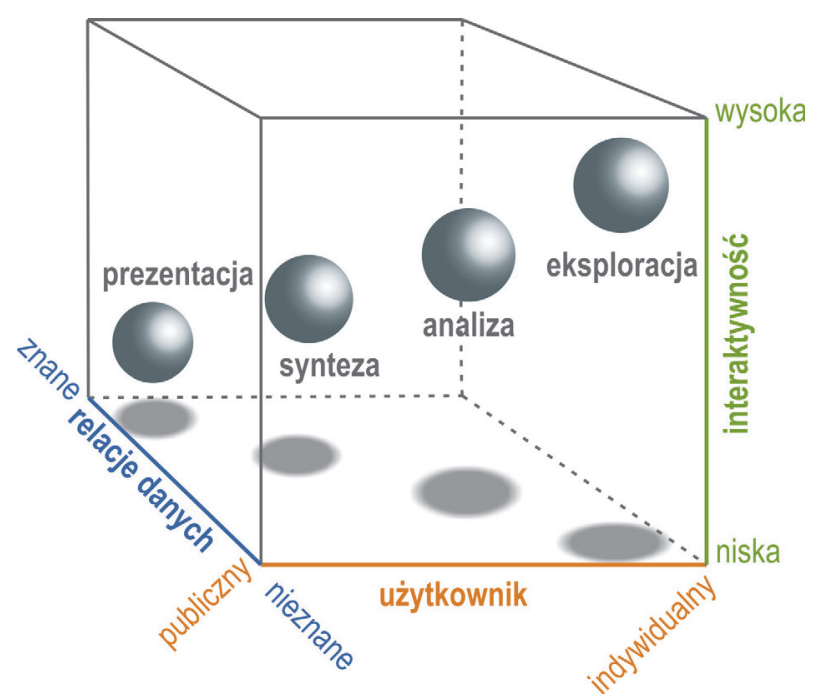

Rycina 1.1. Sześcian użytkowania mapy na podstawie A.M. MacEachrena (1995b)

Ilustracją tego ujęcia jest sześcian użytkowania mapy (ryc. 1.1), w którym wyróżniono kilka sposobów pracy z mapą i geowizualizacjami (MacEachren i Kraak 2001). Trzy osie sześcianu odzwierciedlają trzy cechy użytkowania opracowań kartograficznych: poziom interaktywności (od poziomu niskiego do wysokiego), rodzaj użytkownika (indywidualny 
versus publiczny) oraz wiedzę użytkownika na temat wzajemnych zależności między danymi prezentowanymi na mapie (zależności znane versus nieznane). Te wymiary można sprowadzić do: cechy interaktywności, rodzaju użytkownika oraz typu zadania do rozwiązania (Çöltekin, Janetzko i Fabrikant 2018).

W zależności od wartości tych trzech zmiennych, wyróżnionych na osiach, inny jest sposób pracy z mapą i użytkowania mapy. Z prezentacją mamy do czynienia, gdy dane i zależności między nimi są znane, zatem poziom interaktywności może być niski, a mapa prezentowana jest szerokiemu kręgowi odbiorców. Poziom interaktywności wzrasta wraz z coraz mniejszą wiedzą na temat prezentowanych danych oraz relacji pomiędzy nimi. Sposób użytkowania mapy staje się coraz bardziej „kameralny" i indywidualny: przechodząc przez syntezę, analizę, a kończąc na eksploracji danych nieznanych indywidualnemu użytkownikowi, która odbywa się za pomocą interaktywnych narzędzi. Model ten wskazuje jednocześnie na ważną obecnie rolę mapy w procesie eksploracji i analizy danych, której celem jest ułatwienie wnioskowania i rozwiązywanie problemów. Warto zaznaczyć, że model ten odwołuje się do technologii, która zmieniła się w sposób niewyobrażalny od czasu sformułowania koncepcji przez A.M. MacEachrena, lecz mimo to ujęcie nie straciło na swojej aktualności i trafności.

Innym ujęciem pokrewnym kartografii, które rozszerza jej zakres, jest nauka o informacji geograficznej (ang. Geographic Information Science, w skrócie GIScience). Termin został wprowadzony na początku lat 90. XX wieku przez M.F. Goodchilda (1992) jako rozwinięcie przyjętego wcześniej terminu Geographic Information Systems (systemów informacji geograficznej, GIS). Istniała potrzeba systematycznego i naukowego ujęcia zagadnień żywiołowo rozwijanych dzięki pojawieniu się technologii i programów typu GIS. GIScience to dyscyplina naukowa, która kładzie nacisk na sposób opracowania danych i aspekt technologiczny, z którymi mierzy się kartografia. Potwierdzenie ugruntowania się tego ujęcia można znaleźć w tytułach uznanych czasopism naukowych (np. „Cartography and Geographic Information Science” czy „International Journal of Geographic Information Science"), które poruszają problematykę kartograficzną.

Różne terminy zatem funkcjonują obecnie równolegle. Ujmują one podobnie zagadnienia kartografii i map, ale pod nieco innym kątem, kładąc nacisk na inne aspekty. Jak wykazała analiza prac opublikowanych w latach 1800-2008 przeprowadzona przez A. Çöltekin i współautorów (2017), częstość stosowania różnych terminów zmieniała się na przestrzeni kilku ostatnich dekad (ryc. 1.2). Termin „kartografia” używany był w XIX wieku i nadal jest powszechnie stosowany. Z kolei terminy 

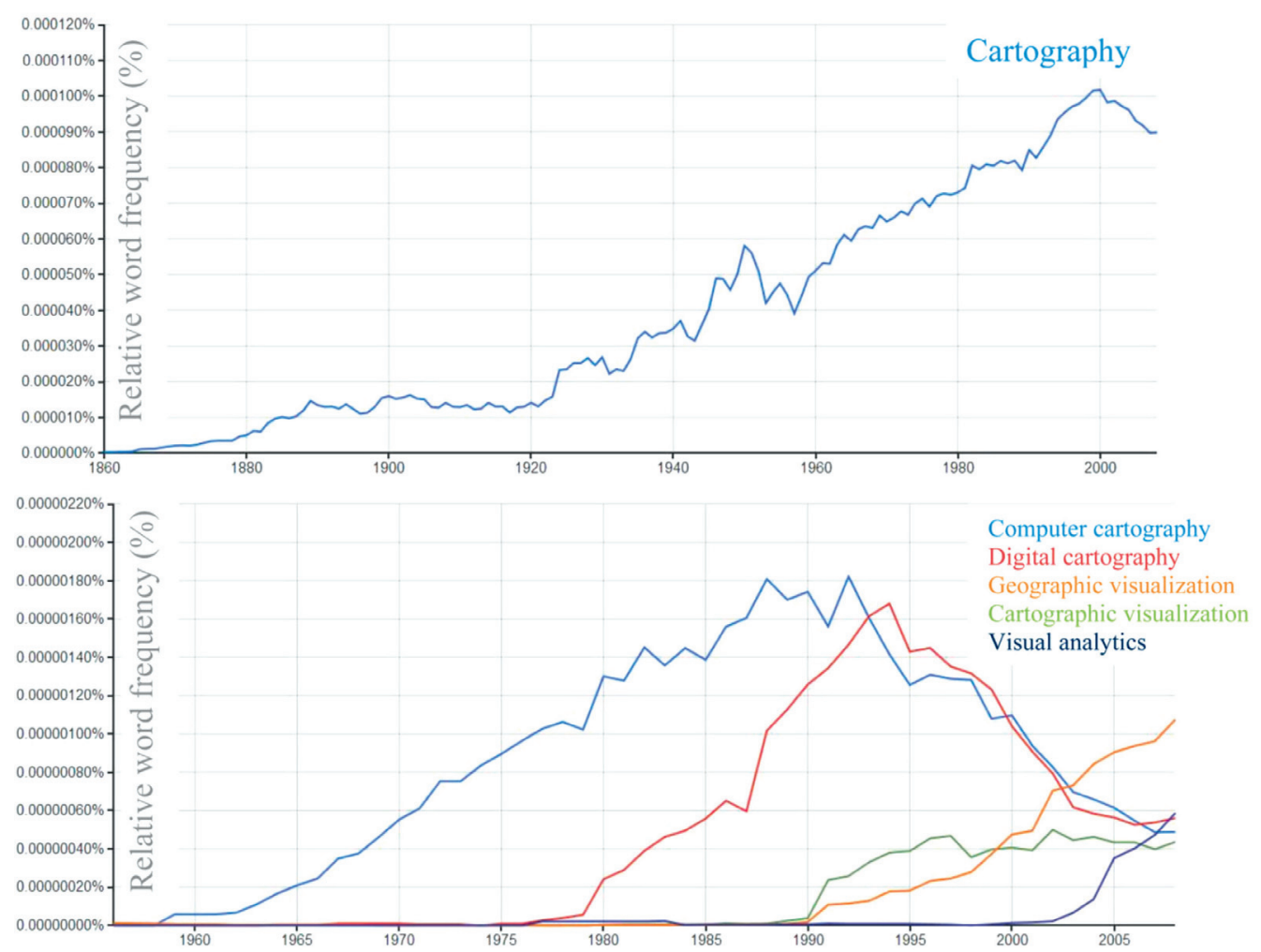

Rycina 1.2. Częstość użycia terminów związanych z kartografią Źródło: A. Çöltekin i współautorzy (2017)

związane z technologiami komputerowymi pojawiły się - siłą rzeczy dopiero $w$ drugiej połowie XX wieku, a ich popularność zmieniała się z czasem: terminy „kartografia komputerowa” czy „kartografia cyfrowa” po początkowym okresie popularności zaczęły być porzucane na rzecz terminu „wizualizacja kartograficzna”, a następnie „geowizualizacja”. Z kolei początek XXI wieku przyniósł jeszcze inne ujęcie - geoanalityki wizualnej (geovisual analytics ${ }^{1}$ ) nawiązującej do rozwijającej się visual analytics - kładące nacisk na analizy informacji przestrzennych z wykorzystaniem interaktywnych wizualizacji (Robinson 2017). Fundamenty tego ujęcia można dostrzec w geografii analitycznej (ang. analytical geography) (Tobler 1976) oraz kartograficznej metodzie badań (Saliszczew

${ }^{1}$ Z powodu braku powszechnie przyjętego polskiego tłumaczenia tego szerokiego pojęcia stosowany będzie oryginalny angielskojęzyczny termin. 
1973), która koncentruje się na zastosowaniu map do analizy naukowej, czyli badania i poznawania zjawisk.

Zatem w zależności od tego, który aspekt jest rozważany i znajduje się w centrum uwagi, używane są różne terminy. Jednak nie można powiedzieć o zaniku kartografii jako dyscypliny czy też o bezsprzecznym rozwiązaniu problemów, którymi zajmuje się kartografia jako nauka. Powinno się raczej tę sytuację traktować jako ewolucję zakresu zainteresowań kartografii, która nadal jest aktualnym wyzwaniem, rozpatrywanym w rozmaitych aspektach i kontekstach, których zróżnicowanie wzrosło wraz z cyfrową rewolucją.

Podobnie jak zmienia się oblicze kartografii jako dyscypliny naukowej, w praktyce kartograficznej również mamy do czynienia z ewolucją. Obecnie funkcjonują zarówno statyczne opracowania, jak i geowizualizacyjne narzędzia interaktywne. Z pewnością nie można przesądzić o absolutnej wyższości jednej z tych dwóch opcji. Są to uzupełniające się opracowania, które służą odmiennym celom w różnych kontekstach i okolicznościach (Słomska-Przech i Gołębiowska 2020; Słomska 2021). Mapy statyczne, drukowane na papierze czy prezentowane na ekranie monitora, pomimo że nie posiadają funkcji interaktywnych, nadal pozostają szeroko wykorzystywane. Z jednej strony wpływ na to ma przyzwyczajenie użytkowników, ale z drugiej - wciąż istnieją obszary aktywności ludzkiej i okoliczności, w których opracowania statyczne są bardziej oczywistym wyborem (np. turystyka piesza, prasa, szkolna kartografia atlasowa). Oferta map drukowanych, czy to turystycznych, topograficznych czy tematycznych, jest nadal bogata i wciąż znajduje szerokie grono odbiorców. W związku z tym również klasyczne zagadnienia redakcji map statycznych znajdują się nieustannie w zakresie zainteresowań kartografów i ich badań.

Wraz z pojawieniem się nowych rozwiązań technologicznych w zakresie geowizualizacji, w tym również interaktywności, która stała się kolejną istotną cechą mapy (Roth 2012), wzrosły liczba i zakres problemów redakcyjnych. Interaktywność rozumiana jest jako dialog między użytkownikiem a opracowaniem kartograficznym za pomocą urządzenia komputerowego (Roth 2013a). Obejmuje szereg rozwiązań, które są określane i porządkowane w różny sposób. M. Okonek (2000), gdy analizował atlasy interaktywne, wyróżnił funkcje: nawigacyjne (obejmujące nawigację przestrzenną, skalową, tematyczną i zmianę formy prezentacji), identyfikacyjne, orientacyjne (np. wyszukiwanie, planowanie tras), kartometryczne (obejmujące pomiary), analityczne (umożliwiające transformację mapy, np. jako profil terenu) oraz komunikacji zewnętrznej (jak eksport, wydruk, pobranie). R.E. Roth (2012) podjął się próby porównania szeregu istniejących klasyfikacji technik interaktywności, 
wykazując, że wiele z nich wyróżnia podobne operacje, takie jak zaznaczanie elementów, wyróżnianie wybranych obiektów, pokazywanie połączeń między elementami czy powiększanie. Pogrupował również techniki interaktywności na mapach, wyróżniając trzy ich główne kategorie: zmianę symbolizacji prezentacji kartograficznej, nawigację (włączając $w$ to zmianę zasięgu oraz skali prezentacji) oraz techniki umożliwiające uzyskanie dodatkowych informacji, również w celu przygotowania do kolejnych interakcji, jak na przykład dodawanie obiektów, usunięcie, pobranie części obiektów, odczyt historii działań. Z kolei na podstawie badań przeprowadzonych z użytkownikami i ekspertami ten sam autor, R.E. Roth (2013b), zaproponował nieco inne ujęcie: wyróżnił dwanaście funkcji realizowanych $w$ trakcie pracy $z$ interaktywnym opracowaniem oraz pięć funkcji umożliwiających rozszerzenie istniejącego środowiska pracy. W pierwszej grupie uwzględnił następujące funkcje: zmianę formy prezentacji, zmianę grafiki, zmianę położenia elementów w obrębie interfejsu, prezentację zmiany w czasie, naniesienie dodatkowych informacji, zmianę prezentowanego obszaru, zmianę skali, zmianę odwzorowania, wyszukiwanie, filtrowanie, pozyskiwanie informacji oraz obliczenia. W grupie drugiej wymienione zostały następujące funkcje: import, eksport, zapisanie, edycja oraz notatki. Różny sposób porządkowania interaktywności świadczy z jednej strony o dużym zróżnicowaniu tych funkcji, o ich rozwoju, a także o różnej wadze, jaką przykłada się do poszczególnych aspektów pracy z pomocą narzędzia interaktywnego. Nowe rozwiązania, otrzymane w wyniku zastosowania choćby części $z$ tych technik interakcji, są często atrakcyjne i przyciągają uwagę, ale nie zawsze stanowią opracowania bardziej użyteczne niż te statyczne (Roth i współautorzy 2017).

Zgodnie z przewidywaniami duża część opracowań kartograficznych jest obecnie redagowana w celu publikacji w Internecie (Berlant 1999). Sam proces redakcji również może odbywać się za pomocą narzędzi dostępnych w Internecie. Redaktorami - z racji dostępności narzędzi - nierzadko są osoby bez przygotowania kartograficznego (Gotlib i Kukułka 2011; Kukułka i Gotlib 2014). Jak stwierdza D. Gotlib (2008a), ważną rolą kartografów jest zatem zapewnienie wsparcia tym osobom. Również projektowanie całych serwisów geoinformacyjnych jest procesem angażującym specjalistów różnych dziedzin (Kowalski 2008). Także w tym przypadku wsparcie przez kartografa jest niezbędne (Gotlib 2008b). Zatem rola kartografów w tych nieco odmiennych okolicznościach pozostaje ważna. Powinni oni zaoferować zarówno fundamenty o charakterze teoretycznym, jak i wsparcie metodyczne, które również czerpie z teoretycznych podstaw. 


\subsection{Oczekiwania wobec współczesnych opracowań kartograficznych}

Obecnie opracowanie i użytkowanie map wiąże się w dużej mierze z problemami szeroko pojętej wizualizacji danych. Ważne są walory estetyczne takich opracowań. Mapy od zawsze rozpatrywane były w wymiarze estetycznym, pełniły także funkcję dekoracyjną i ten aspekt, wprawdzie osadzony w kontekście technologii komputerowych, również dzisiaj nie traci na ważności. Rola mapy została jednak znacznie rozbudowana w wymiarze funkcjonalnym. Mapa powinna obecnie być nie tylko ładna, lecz przede wszystkim funkcjonalna i użyteczna. Powinna być skutecznym narzędziem do analizy i zrozumienia prezentowanych danych przestrzennych. Jako narzędzie graficzne, mapy - razem z innymi sposobami wizualizacji danych - zyskują na znaczeniu w różnych dziedzinach działalności człowieka. W obecnych czasach przekaz wizualny cenimy wyżej od tekstowego, z większą łatwością przychodzi nam coś obejrzeć niż wnikliwie przeczytać tekst. Istotną rolę $w$ tym procesie odgrywa czas: chcemy mieć szybki dostęp do informacji, chcemy szybko ją odczytać, szybko zrozumieć, aby jak najszybciej podjąć odpowiednie decyzje. Tym bardziej problemy opracowania czytelnych i efektywnych map, a także szerzej ujmując: geowizualizacji, nie tracą na aktualności, wręcz przeciwnie - przyciągają uwagę coraz szerszego grona kartografów, zarówno praktyków, jak i teoretyków.

Oczekiwania te są zbieżne ze wskazaną przez W. Ostrowskiego (1974a; 1998) sprawnością mapy. Pojęcie sprawności zaczerpnięto z prakseologii, czyli teorii sprawnego działania. Co ważne, W. Ostrowski (1974a; 1998) zaznaczył, że ocena sprawności może być rozpatrywana z dwóch punktów widzenia: (1) osiągnięcia lub nieosiągnięcia zamierzonego celu, określonych efektów u użytkownika mapy, (2) poprzez ocenę poniesionych kosztów przez osobę opracowującą mapę. O ile ten drugi aspekt staje się coraz mniej istotny wraz ze wzrostem dostępności i przystępności technologii, o tyle waga wysiłku użytkownika mapy nie traci na znaczeniu. Spośród wyróżnionych przez autora trzech aspektów sprawności: semantycznego, pragmatycznego i produkcyjnego, drugi z nich stawia w centrum zainteresowania odbiorcę mapy i potrzebę dostosowania opracowania do możliwości i potrzeb użytkownika. O sprawności tej decyduje kilka procesów:

- postrzeganie: powiązane z percepcją form wizualnych,

- rozumienie: związane z możliwością poprawnego określenia znaczenia przekazywanych informacji,

- badanie: poprzez analizę treści, wnioskowanie i operacje poznawcze. 
Waga tych zagadnień jest konsekwencją roli, jaką obecnie odgrywa użytkownik mapy. Głos użytkownika jest niezwykle ważny, a nawet priorytetowy w procesie redakcji map i innych opracowań kartograficznych. Jest to konsekwencją demokratyzacji kartografii i rozwoju Internetu 2.0, w którym oddolne inicjatywy, z którymi można powiązać użytkownika mapy, mają coraz większe znaczenie (Kukułka i Gotlib 2014).

Jak podkreśla wielu autorów, opracowania kartograficzne powinny być projektowane z myślą o użytkowniku, o jego potrzebach, kontekście użycia, preferencji, ale również o ograniczeniach (Gartner i Huang 2016). Uznanie wagi tych aspektów w projektowaniu map było jedną z przyczyn rozwoju i stałej popularności kartografii poznawczej wykorzystującej teorie i metody psychologiczne do badania odbioru map (Montello 2009). Wiedza na temat systemu wzrokowego, procesów poznawczych czy sposobu postrzegania przez ludzi informacji z prezentacji graficznych jest ważnym elementem badań efektywności geowizualizacji (Çöltekin, Griffin i Robinson 2021). Oczekiwania i możliwości użytkowników nabierają jeszcze większego znaczenia w odniesieniu do aktualnie rozwijanych geowizualizacji. Znaczenie i waga zdefiniowania potrzeb użytkowników wzrastają bowiem wraz z poziomem zaawansowania i złożoności aplikacji (Griffin, Robinson i Roth 2017).

Środowisko naukowe także ma świadomość wagi tych problemów. A. Çöltekin i współautorzy (2017) zebrali opinie wśród członków społeczności akademickiej i naukowej, reprezentujących kartografię i geowizualizację, na temat stałych wyzwań tych dyscyplin. Najczęściej udzielane odpowiedzi dotyczyły kwestii użytkownika i użyteczności. Pojawiały się głosy na temat takich zagadnień, jak: zrozumienie roli czynników ludzkich w trakcie całego procesu projektowania i użytkowania narzędzi geowizualizacji, relacja pomiędzy użytkownikiem, zadaniami i sposobem wizualizacji danych, wpływ różnych sposobów prezentacji i kontekstów użycia na pracę użytkownika, a także znaczenie różnych cech użytkownika (wykształcenie, doświadczenie, preferencje, nawyki, wymagania) i ich wpływ na sposób pracy z geowizualizacjami.

Potrzeba uwzględniania potrzeb użytkowników w formułowaniu problemów badawczych również znalazła odzwierciedlenie w kolejnych agendach badawczych kartografii i geowizualizacji (w tym w Międzynarodowej Asocjacji Kartograficznej) na przełomie XX i XXI wieku (MacEachren i Kraak 1997; Fairbairn i współautorzy 2001; Laramee i Kosara 2006; Andrienko i współautorzy 2007; Virrantaus, Fairbairn i Kraak 2009). W opracowaniach tych wysuwane były postulaty dotyczące takich problemów, jak:

- potrzeba zrozumienia procesów poznawczych związanych z postrzeganiem obrazów wizualnych, 
- określenie zależności między sposobem projektowania a percepcją i procesami poznawczymi,

- wizualizacja jako narzędzie podejmowania decyzji,

- ocena użyteczności, w tym ocena efektywności i sposobu pracy z opracowaniami kartograficznymi.

Badania mające na celu dostosowanie opracowań kartograficznych i geowizualizacji do potrzeb użytkownika czerpią z idei użyteczności (ang. usability), problematyki zaczerpniętej z informatyki. J. Nielsen (1993) zdefiniował użyteczność jako łatwość obsługi programu komputerowego i scharakteryzował ją za pomocą pięciu aspektów:

1) nauczalność (ang. learnability): odnosi się do łatwości, z jaką użytkownicy są w stanie wykonać podstawowe działania $w$ ramach nieznanego systemu,

2) efektywność (ang. efficiency): czas, w jakim użytkownik jest w stanie te zadania wykonać,

3) zapamiętywalność (ang. memorability): łatwość, z jaką powracający po pewnym czasie użytkownik jest w stanie przypomnieć sobie specyfikę działania w ramach interfejsu strony,

4) błędy (ang. errors), które popełnia użytkownik, wykonując zadania w danym interfejsie, jak poważne są to błędy oraz ile pracy wymaga wyeliminowanie ich skutków lub następstw,

5) satysfakcja (ang. satisfaction): poziom zadowolenia, jaki towarzyszy użytkowaniu danego systemu.

Waga tego zagadnienia pociągnęła za sobą potrzebę standaryzacji pojęć związanych z użytecznością. Użyteczność definiuje np. norma ISO 9242-11 Międzynarodowej Organizacji Standaryzacyjnej (ang. International Organisation for Standarization). Jest ona rozumiana jako cecha określająca zakres celów osiągniętych przez użytkowników skutecznie, wydajnie oraz z satysfakcją w danym kontekście użycia. Kontekst ten określają: zadania, wykorzystane narzędzia oraz środowisko pracy (ryc. 1.3) (ISO 9241-11:2018).

Zostały zatem określone miary użyteczności, które są często stosowane w badaniach empirycznych, również w obszarze kartografii i geowizualizacji (Çöltekin i współautorzy 2009; Gołębiowska 2015). Najczęściej stosowane to poprawność oraz czas odpowiedzi, informujące odpowiednio o skuteczności oraz efektywności ocenianego opracowania. Nauczalność również jest wartościowym wskaźnikiem użyteczności w przypadku nowych rozwiązań, które nie są popularne i szeroko stosowane. Wskaźnik ten koncentruje się na łatwości, z jaką przychodzą użytkownikom zrozumienie celu opracowania i nauka jego obsługi. Zagadnienie to jest naturalnie przedmiotem badań również na płaszczyźnie geowizualizacji (Andrienko i współautorzy 2002). 


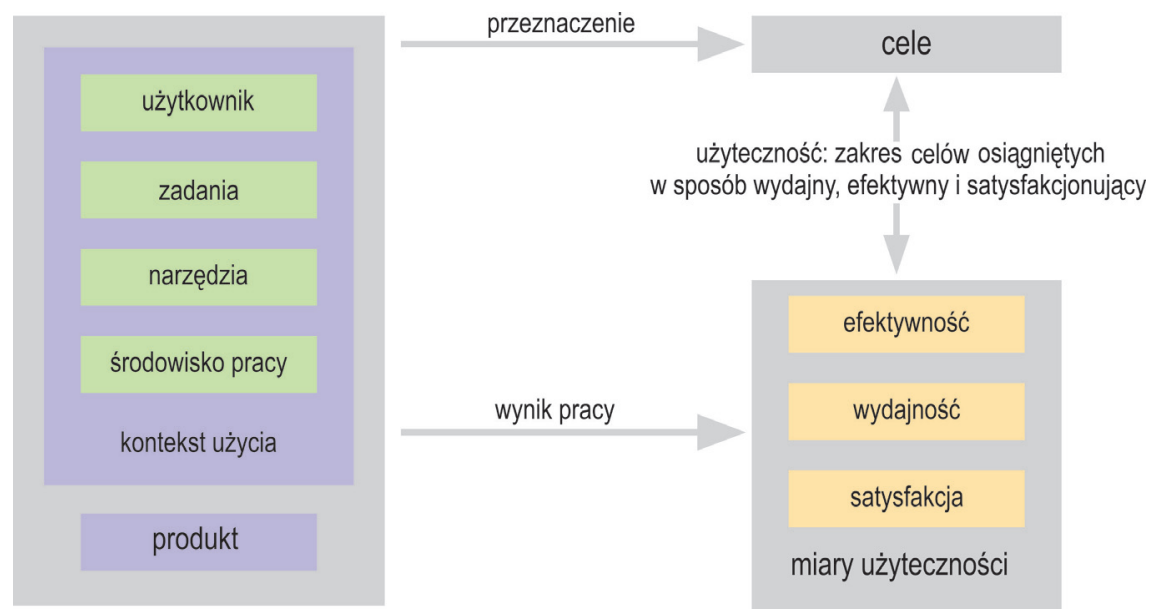

Rycina 1.3. Schemat pomiaru użyteczności według ISO 9241-11:2018 Ergonomics of Human-System Interaction - Part 11: Usability: Definitions and Concepts

\subsection{Semiotyka kartograficzna}

Projektowanie map, zarówno tych statycznych, jak i tych dynamicznych, rozbudowanych o funkcje interaktywne, może być rozważane z perspektywy innej dyscypliny, a mianowicie semiotyki kartograficznej. Semiotyka kartograficzna to dziedzina wiedzy zajmująca się znakami kartograficznymi, ich istotą, definicjami, funkcjami, klasyfikacjami, systemem ich opracowania, ekspresją, właściwościami poznawczymi (Ostrowski 2008). To także jedno z ważnych podejść teoretycznych funkcjonujących w kartografii obok takich teorii, jak przekaz kartograficzny (Ratajski 1978) czy modelowanie kartograficzne (Asłanikaszwili 1974).

Semiotyka kartograficzna cechuje się silną podbudową teoretyczną, czerpiącą z innej dziedziny nauk - semiotyki. Semiotyka to nauka o znakach, której zadaniem jest analiza ich budowy, sposobu funkcjonowania w społeczeństwie oraz reguł nimi rządzących (Pelc 1984). Jej syntezą jest idea znaku jako triady: „znak - obiekt - interpretant”, sformułowana przez Ch. Peirce'a (ryc. 1.4). Badacz wyróżnił kilka rodzajów znaków, wśród nich - znaki ikoniczne, do których zaliczył również mapy (Pelc 1984). Znaki ikoniczne są podobiznami, obrazami tego, co przedstawiają, zatem posiadają pewne cechy prezentowanego obiektu. Podobieństwo między znakiem ikonicznym a obiektem nie jest naturalne. Znak ikoniczny może być postrzegany jako podobny przez osobę interpretującą znak. Dlatego znaki ikoniczne są uważane za „kod słaby”, czyli taki, który nie 
zastępuje obiekt nie w pełnym zakresie, lecz odnosi się do wybranych właściwości

\section{ZNAK}

\section{Obiekt}

realna, istniejąca rzecz, zdarzenie lub zjawisko

\section{Interpretant}

idea, termin, myśl, jaką tworzy w umyśle osoba nadajaca znaczenie symbolowi

Rycina 1.4. Koncepcja znaku według Ch. Peirce’a, na podstawie J. Pelca (1984)

zawsze jest jednoznacznie odczytywany, ale raczej jest interpretowany (Bouissac 1991). Mapy mogą stanowić mocniejszy kod, na przykład w wyniku standaryzacji znaków (Zabrodin, Onoprienko i Sołowiew 1985), jak to ma miejsce na mapach geologicznych. W przypadku większości map interpretuje się znaki, a wpływ na określanie podobieństwa między znakiem a obiektem może mieć między innymi konwencja kulturowa. Dlatego w analizach i badaniach map ważne jest uwzględnienie potrzeb, przyzwyczajeń oraz możliwości użytkownika, gdyż one w dużej mierze będą decydowały o skuteczności mapy. T. Komendziński (1996) zauważa jednocześnie, że integralną częścią mapy jako znaku ikonicznego jest legenda.

Oprócz rozważań semiotyków na temat mapy teoretyczne koncepcje o mapie jako zbiorze znaków rozwijane były również przez kartografów. W połowie lat 60. XX wieku zaczęto stosować teorię znaku w kartografii, co skutkowało powstaniem i rozwinięciem semiotyki kartograficznej. Rok wydania książki J. Bertina Semiologie graphique. Les diagrammes, les reseaux, les cartes (Bertin 1967) uważany jest za początek semiotyki kartograficznej (Ostrowski 2013). Autor określił w niej zasady funkcjonowania różnych form graficznych, włączając w to mapy. U. Freitag (1971) uznał, że semiotyka kartograficzna powinna odzwierciedlać strukturę samej semiotyki. Wyróżnił zatem, za Ch. Morrisem - uczniem Ch. Peirce'a, trzy działy semiotyki kartograficznej: semantykę kartograficzną, syntaktykę kartograficzną oraz pragmatykę kartograficzną (ryc. 1.5).

Semantyka kartograficzna zajmuje się relacjami między znakami kartograficznymi i ich kombinacjami a przedstawianymi obiektami. Relacje te wyjaśnione są w legendzie mapy. Syntaktyka kartograficzna bada 


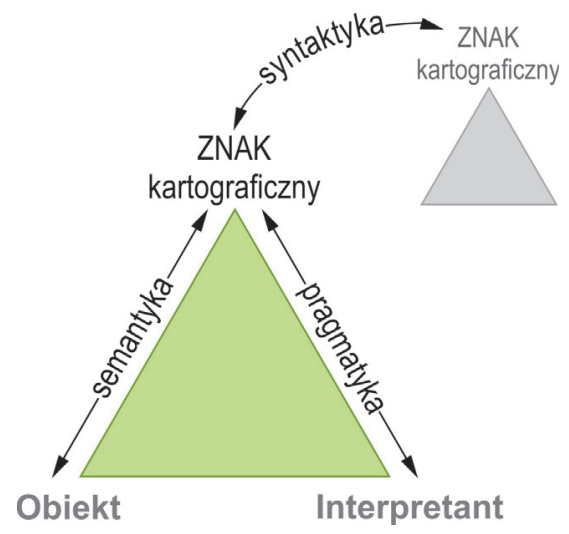

Rycina 1.5. Aspekty semiotyki kartograficznej, na podstawie W. Ostrowskiego (2008)

reguły „składni” mapy: budowę i uporządkowanie znaków kartograficznych oraz reguły ich opracowania, przekształcania i łączenia, przy czym nie uwzględnia znaczenia tych znaków. Z kolei pragmatyka kartograficzna w centrum swoich zainteresowań stawia związki między kartograficznymi środkami i formami przedstawiania a twórcą i użytkownikiem mapy, w tym problemy percepcji i projektowania (Ostrowski 2008, Gołębiowska 2011).

Niezaprzeczalnym wkładem w rozwój ujęcia mapy jako przedmiotu badań semiologii graficznej jest koncepcja J. Bertina (1967; 1983). Uważał on, że percepcją wizualną racjonalnych przedstawień graficznych (jak sieci, diagramy, mapy) kierują dwa rodzaje zmiennych: położenie (dwa wymiary płaszczyzny) oraz zmienne odpowiadające graficznej reprezentacji charakterystyki obiektu, które określił jako zmienne wizualne (ryc. 1.6). Autor wyróżnił sześć zmiennych wizualnych: kształt, orientację, ziarnistość, kolor, jasność i wielkość. Każda z nich może posłużyć do przekazania jednej lub kilku relacji: podobieństwa, różnicy, uporządkowania oraz proporcjonalności.

Lista sześciu zmiennych graficznych była później modyfikowana i rozbudowywana, również z powodu pojawienia się nowych środków wyrazu. A.M. MacEachren (1995a) rozbudował tę listę o takie zmienne, jak: ostrość, rozdzielczość, przezroczystość, nasycenie barwy, tekstura, rozmieszczenie. Innego rodzaju mapy, wykraczające poza klasyczne mapy postrzegane wzrokiem, również posługują się dodatkowymi zmiennymi. Tyflomapy, czyli mapy przeznaczone dla osób z dysfunkcją wzroku (niewidomych i słabowidzących), posługują się zmiennymi 


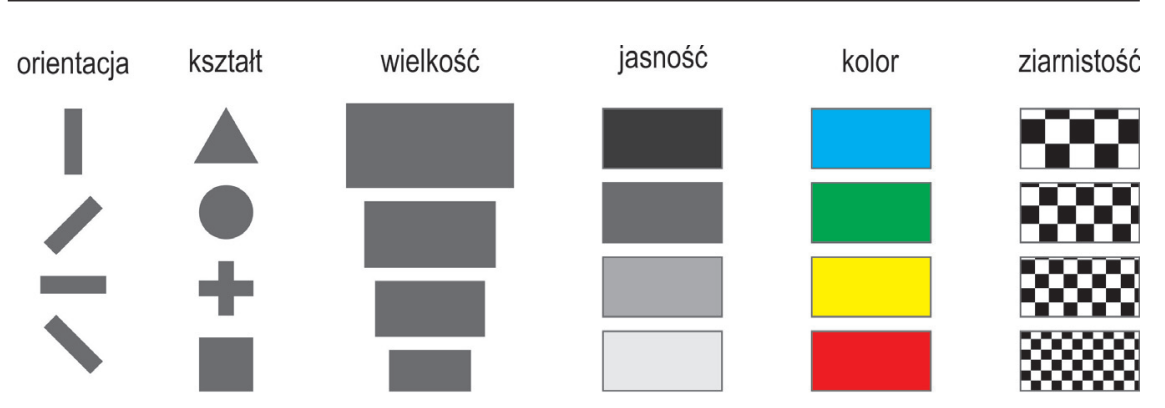

położenie

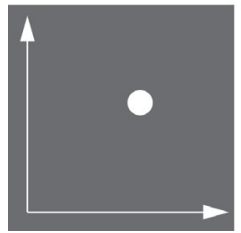

Rycina 1.6. Zmienne graficzne wyróżnione przez J. Bertina (1967)

haptycznymi o charakterze dotykowym. Wśród tych zmiennych wyróżnia się wysokość, teksturę, szorstkość, wysokość znaku (Vasconcellos 1992). Zmienne dynamiczne, mające zastosowanie na mapach animowanych (Dukaczewski 2019), obejmują następujące charakterystyki: długość trwania, kolejność, tempo zmian, moment wyświetlania, częstotliwość, synchronizacja (MacEachren 1995a; DiBiase i współautorzy 1992). Z kolei mapy soniczne, wykorzystujące do prezentacji dźwięk, posiadają również dodatkowy zestaw zmiennych sonicznych, takich jak: głośność, częstotliwość, tembr, długość, tempo zmian, kolejność, wysokość tonu, zanikanie (Krygier 1994).

Informacja na mapie jest zatem prezentowana za pomocą kodu znakowego, który może wykorzystywać różne środki wyrazu i różne zmienne. Niezależnie od rodzaju zmiennych kod ten funkcjonuje w działalności człowieka obok innych kodów znakowych: języka mówionego, słowa pisanego, muzyki, sztuki wizualnej i innych. Mapa mieści się w szerokiej kategorii znaków graficznych, które są uważane za wysoce „zwarte” (zgodnie z popularną maksymą ,jeden obraz jest wart tysiąc słów") i dzięki temu obecnie są one coraz częściej wykorzystywane. Mapa posługuje się głównie kodem obrazkowym, w legendzie zaś następuje jego „łłumaczenie” na język naturalny. Legendę można zatem rozpatrywać zarówno z punktu widzenia semantyki, gdyż prezentuje znaczenie użytych znaków, jak i pragmatyki kartograficznej, ponieważ jej głównym celem 
jest dostarczenie odbiorcy możliwie kompletnych informacji (Ostrowski 2013). Informacje te nie ograniczają się tylko do objaśnienia znaków, ale obejmują również m.in. tytuł, skalę, odwzorowanie (Kałamucki 2005; Gołębiowska 2011).

\subsection{Semiotyka kartograficzna a geowizualizacje wieloelementowe}

Analiza mapy z punktu widzenia semiotyki kartograficznej pozwala na szerokie spojrzenie, przy jednoczesnym uwzględnieniu jej specyfiki jako środka wyrazu i przekazywania informacji przestrzennej. Przykładem tego typu rozważań jest zarówno zagadnienie projektowania map topograficznych (Ostrowski 2008), planów miast (Ostrowski 1974b), analiza map tematycznych pod kątem kategorii ontologicznych i graficznych środków semiotycznych (Żyszkowska 2000), jak i projektowania map cyfrowych przez osoby bez wykształcenia kartograficznego (Medyńska-Gulij 2010; 2007b). Jednocześnie semiotyka kartograficzna nie powinna być uważana za podejście konkurencyjne dla geowizualizacji, lecz jako uzupełnienie spojrzenia, a dokładniej - jako wzajemnie uzupełniające się perspektywy.

Rozpatrywanie geowizualizacji wieloelementowych z punktu widzenia semiotyki jest o tyle cenne, że umożliwia uwzględnienie różnych form stosowanych w tego typu opracowaniach. Z punktu widzenia semiotyki zarówno wykres, diagram, jak i mapa to różne formy, w których za pomocą różnego typu kodu znakowego (Bertin 1983) jest zakodowana informacja. Dzięki temu można analizować te wszystkie formy prezentacji w sposób jednolity. Pozwala to spojrzeć na zagadnienie odkodowania, tłumaczenia znaczenia użytych znaków jednocześnie we wszystkich modułach. Podobnie kwestie semantyczne, czyli informacja, jaka jest zakodowana za pomocą znaków, mogą być podjęte i analizowane jednocześnie w odniesieniu do całej geowizualizacji wieloelementowej. Z kolei spojrzenie z perspektywy możliwości i potrzeb użytkownika tego typu opracowań, czyli z punktu widzenia pragmatyki kartograficznej, dostarczyć może cennych wskazówek i wniosków. Dzięki odniesieniu geowizualizacji wieloelementowych do koncepcji teoretycznej o szerokich ramach, jaką jest semiotyka kartograficzna, możliwe jest zatem spójne rozważanie zagadnień dla całego opracowania, a nie wyrywkowo dla jego pojedynczych elementów. 


\section{Geowizualizacje wieloelementowe}

\subsection{Idea geowizualizacji wieloelementowych}

Przykładem rozwiązań, które pojawiły się dzięki cyfrowej rewolucji oraz wprowadzeniu interaktywności do prezentacji danych, są wizualizacje wieloelementowe $^{1}$ (ang. coordinated and multiple views, CMV, coordinated and linked views). Wraz z ogromnym wzrostem liczby danych przestrzennych i ich powszechną dostępnością geowizualizacje wieloelementowe znalazły zastosowanie również w wizualizacji geograficznej (geowizualizacji), a nawet zostały uznane za jedne z ważniejszych rozwiązań w wizualizacji geograficznej (Koua, MacEachren i Kraak 2006). Geowizualizacje wieloelementowe umożliwiają zestawienie kilku różnych form prezentacji danych pokazanych jednocześnie w oddzielnych modułach. Moduły te połączone są ze sobą przy pomocy narzędzi interaktywności (Roberts 2007), tak aby ułatwiać eksplorację prezentowanych w nich danych (Baldonado, Woodruff i Kuchinsky 2000).

Zestawienie kilku form prezentacji umożliwia podkreślenie rozmaitych aspektów danych oraz spojrzenie na te dane pod różnym kątem. Tym samym geowizualizacje wieloelementowe wykorzystują potencjał zróżnicowanych form wizualizacji danych. Otwiera to zarówno przed kartografią, jak i geowizualizacją możliwość rozszerzenia przestrzeni badawczych realizowanych przez inne dyscypliny, prężnie rozwijające się i o szerokim zasięgu oddziaływania, takie jak na przykład wizualizacja naukowa. Przykładem tego typu rozwiązania jest narzędzie o nazwie Regions and Cities Illustrated (RCl), oferowane przez Eurostat. Jest ono zbudowane z dwóch modułów, w których użytkownik może wyświetlić różne zestawy

${ }^{1}$ W dalszej części opracowania stosowane będą terminy „wieloelementowe narzędzia geowizualizacji” w odniesieniu do konkretnych opracowań oraz „geowizualizacje wieloelementowe" w ogólnym ujęciu. 


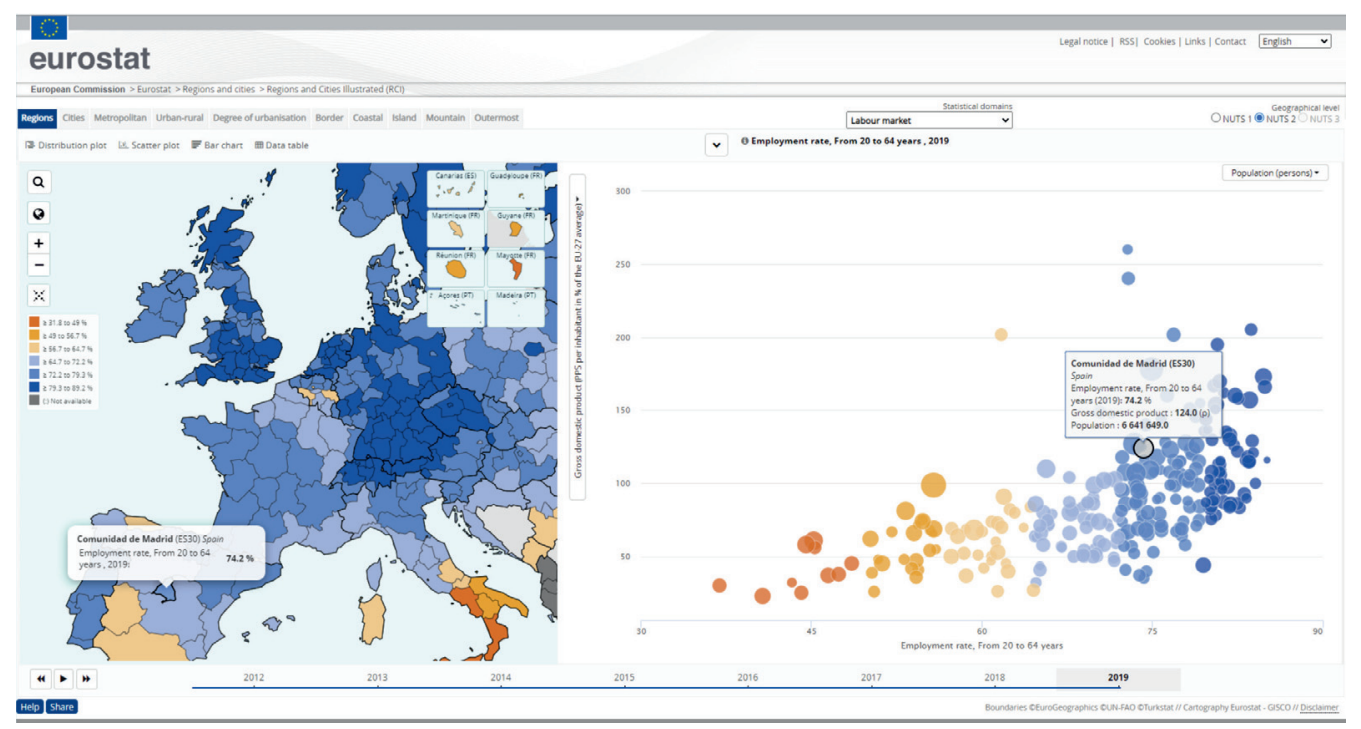

Rycina 2.1. Przykład wieloelementowego narzędzia geowizualizacji: Regions and Cities I/lustrated (RCl) opracowanego dla Eurostat „Regions and Cities Illustrated (RCI)"

danych za pomocą mapy oraz innych metod (wykresu punktowego, słupkowego, tabeli) (ryc. 2.1).

Wieloelementowe geowizualizacje mogą być postrzegane jako rodzaj coraz bardziej popularnych opracowań typu dashboard, które również składają się z wielu modułów, ale nie zawsze te moduły są ze sobą interaktywnie połączone (Zuo, Ding i Meng 2020). Ponadto mają najczęściej nieco inny zakres zastosowań: dashboards to narzędzia służące do podejmowania decyzji operacyjnych, których zadaniem jest integracja danych z różnych źródeł (McArdle i Kitchin 2016; Stehle i Kitchin 2020; Çöltekin, Griffin i Robinson 2021). M.-J. Kraak i współautorzy (2020) wymieniają trzy kategorie dashboard: strategiczny, operacyjny oraz analityczny. Pierwsza kategoria - opracowania o charakterze strategicznym - służy do wyświetlenia kluczowych parametrów w celu ich monitorowania (ryc. 2.2). Z kolei w narzędziach operacyjnych wykorzystuje się zazwyczaj proste mapy i wykresy, które prezentują dane w czasie rzeczywistym i umożliwiają reakcję, gdy wartości danych przekroczą przyjęte normy. Natomiast w grupie analitycznych dashboard M.-J. Kraak i współautorzy (2020) uwzględniają geowizualizacje wieloelementowe. Są to opracowania prezentujące znaczne ilości danych oraz cechujące się bogatą funkcjonalnością. Służą one bowiem 


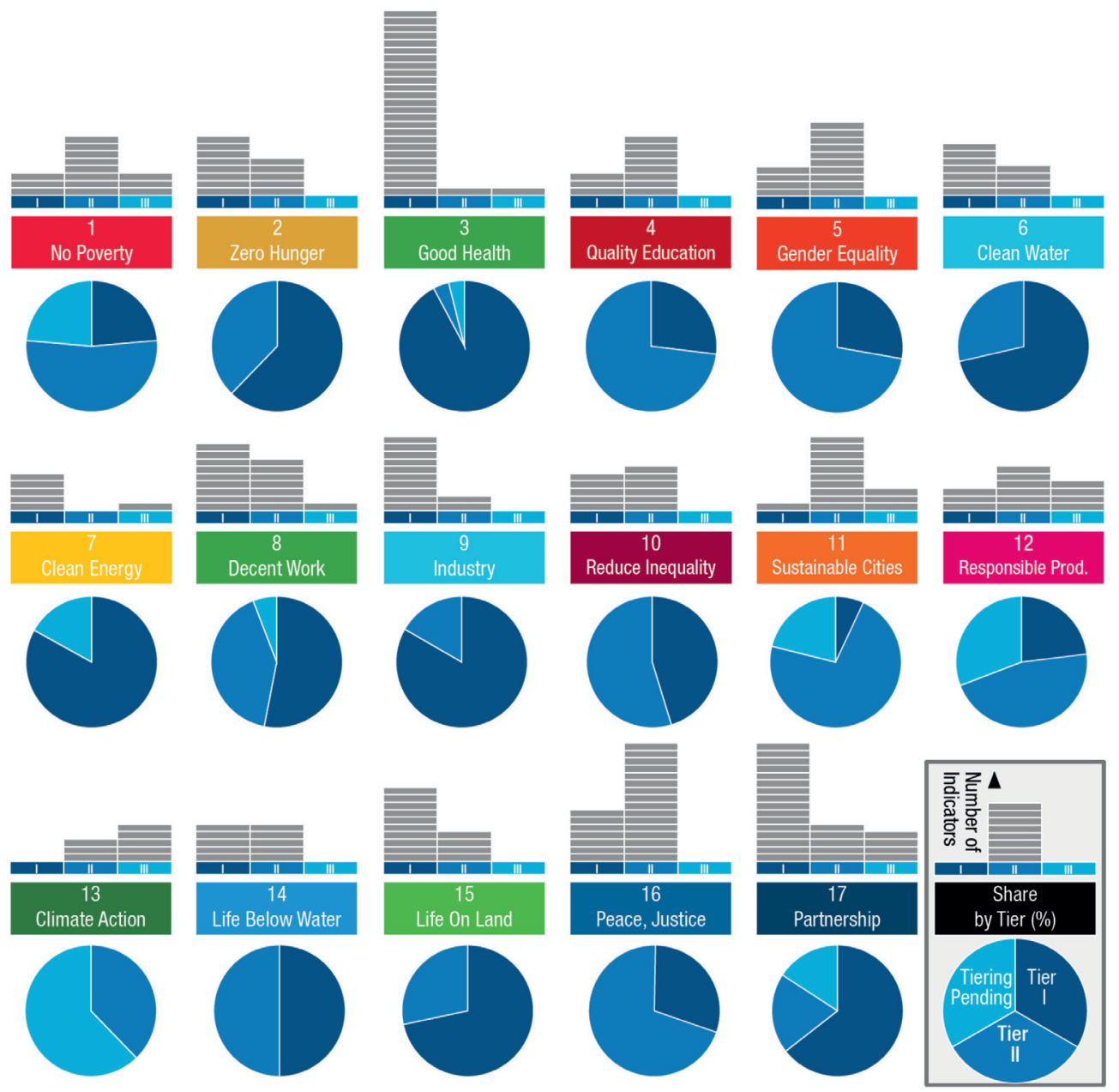

Rycina 2.2. Przykład narzędzia typu dashboard o charakterze strategicznym służącego do monitorowania postępu w zakresie realizacji celów zrównoważonego rozwoju według ONZ. Wysokość słupków prezentuje liczbę wskaźników zrównoważonego rozwoju w podziale na trzy poziomy: obrazujących cele główne (Tier I), cele operacyjne (Tier II) oraz działania (Tiering Pending) w ramach poszczególnych celów zrównoważonego rozwoju

Źródło: M.-J. Kraak i współautorzy (2020)

do poznawania nieznanych informacji, wzorców, trendów oraz anomalii w prezentowanych danych.

Formy wizualizacji wykorzystywane w geowizualizacjach wieloelementowych są bardzo różnorodne. Mogą to być zarówno mapy, diagramy, grafy, wykresy liniowe, wykresy słupkowe oraz wykresy punktowe, jak też 


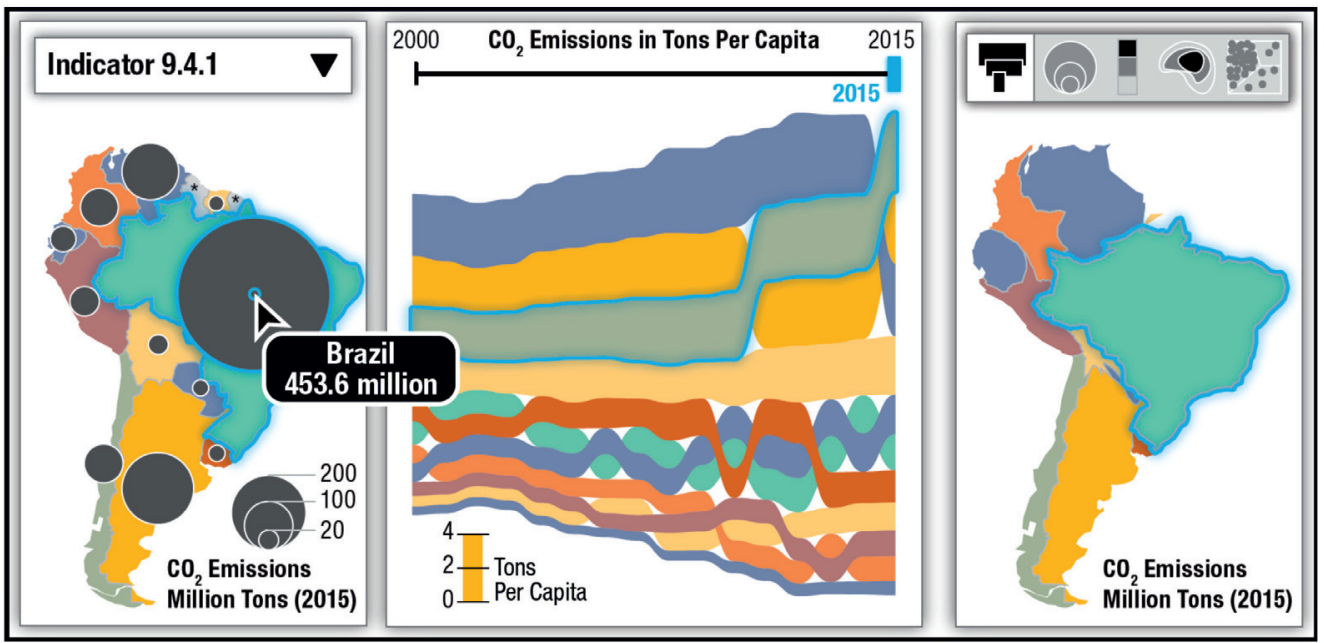

Rycina 2.3. Przykład geowizualizacji wieloelementowej prezentującej te same dane (emisji dwutlenku węgla) w każdym module: kartodiagramu, wykresu oraz mapy anamorficznej

Źródło: M.-J. Kraak i współautorzy (2020)

wykresy osi równoległych, sieci, mapy drzewa (tzw. treemap), infografiki, tabele i inne (Roberts 2007). Każda forma umożliwia nieco inny wgląd w prezentowane dane (Ricker, Kraak i Engelhardt 2020). Różnorodność jest ważną i charakterystyczną cechą współczesnej kartografii (Griffin, Robinson i Roth 2017; Robinson i współautorzy 2017b). Składają się na nią zarówno zróżnicowana tematyka, bogactwo rodzajów danych źródłowych, zróżnicowanie potrzeb i możliwości użytkowników, jak też różnorodność sposobów graficznej prezentacji danych przestrzennych (multimedia, tekst i inne formy wyrazu), które rozszerzają katalog sposobów prezentacji.

Poszczególne moduły geowizualizacji wieloelementowych mogą prezentować te same dane lub różne zestawy uzupełniających się danych, które są dobrane w sposób celowy. Eksplorację tych danych umożliwiają narzędzia interaktywności, przede wszystkim interaktywne połączenie pomiędzy elementami (dynamic linking) oraz filtrowanie i selekcja danych, które odbywają się jednocześnie w kilku elementach (brushing) (Dykes 1997). Dzięki temu zaznaczenie elementów w jednym module skutkuje wyróżnieniem odpowiadających im obiektów w innych modułach opracowania. Przykładowo, na ryc. 2.3 zaznaczenie diagramu prezentującego dane dotyczące Brazylii powoduje wyróżnienie wstęgi na wykresie oraz obszaru Brazylii w pozostałych modułach. 


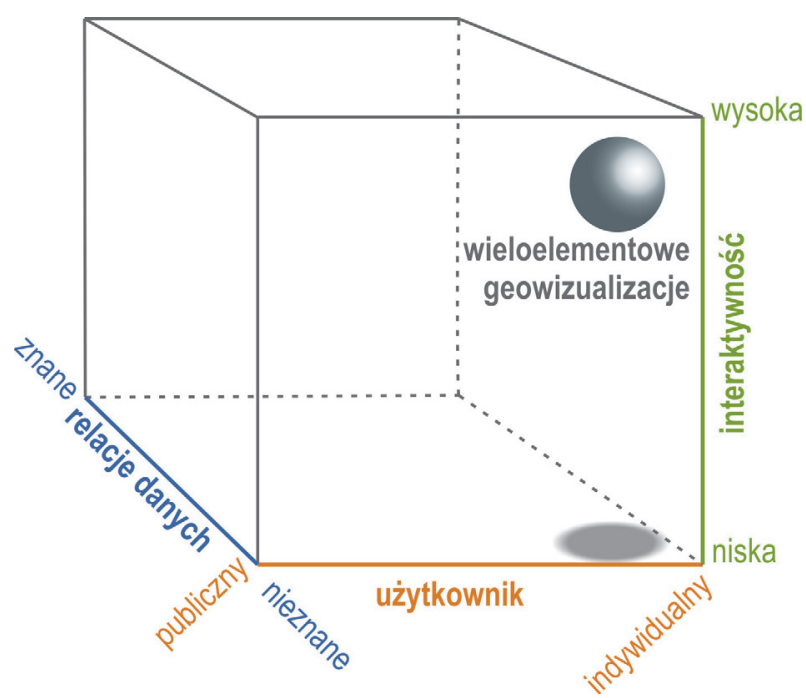

Rycina 2.4. Umiejscowienie geowizualizacji wieloelementowych w obrębie sześcianu użytkowania mapy

Jak stwierdził J.C. Roberts (2007), ludzie lepiej rozumieją dane, jeśli eksplorują je oraz oglądają z różnych perspektyw i za pomocą rozmaitych form prezentacji. Prezentacja kilku różnych elementów jednocześnie w geowizualizacjach wieloelementowych może być bardziej korzystna niż niezależne używanie poszczególnych modułów, zwłaszcza w przypadku złożonych zestawów danych (Edsall 2003). Również I.D. Bishop i współautorzy (2013) wykazali, że użytkownicy, mając do czynienia ze złożonymi zestawami danych, oczekują raczej jednoczesnej ich prezentacji (np. w formie geowizualizacji wieloelementowej) niż wyświetlania ich pojedynczo.

Geowizualizacje wieloelementowe wpisują się w ideę eksploracji danych przeprowadzanej w celu zrozumienia zależności między nimi. Sześcian użytkowania mapy (ryc. 1.1) jest modelem, w obrębie którego można umiejscowić różne formy i narzędzia geowizualizacji. Geowizualizacje wieloelementowe są wartościową pomocą na etapie eksploracji i analizy prezentowanych danych. Zatem na sześcianie tym można umiejscowić je w narożniku charakteryzowanym przez wysoką interaktywność, nieznane relacje między danymi oraz przez indywidualnego użytkownika (ryc. 2.4). Tego typu opracowania są zatem narzędziami do realizowania idei i eksploracji będącej w centrum zainteresowania geovisual analytics (Çöltekin i współautorzy 2019).

Jednym z pierwszych narzędzi tego typu było GeoVISTA Studio opracowane w latach 90. XX wieku (Takatsuka i Gahegan 2002; Gahegan 
i współautorzy 2002). GeoVISTA Studio złożone było z komponentów, które można dowolnie łączyć w jeden graficzny interfejs użytkownika, w zależności od dostępnych danych oraz potrzeb. Innym narzędziem tego typu, opracowanym również w końcu XX wieku, był CommonGIS (Andrienko i współautorzy 2002). Opracowania te wymagały jednak zainstalowania na komputerze użytkownika środowiska uruchomieniowego Java (Java Runtime Environment - JRE), co wiązało się z dodatkowym nakładem pracy: pobrania i instalacji oprogramowania na komputerze użytkownika. Wraz z rozwojem technologii internetowych wykorzystujących biblioteki JavaScript typu open source i umożliwiających udostępnianie nawet złożonych funkcjonalności narzędzia te stały się dostępne z poziomu przeglądarek internetowych (Çöltekin, Janetzko i Fabrikant 2018) i nie wymagały dodatkowego oprogramowania ani konfiguracji. Przykładem może być opracowanie prezentujące aktywność społeczności portalu Panoramio (Medynska-Gulij i Myszczuk 2012), okno geowizualizacji, złożone z kilku paneli: map, wykresów liniowych i tabeli.

Obecnie nawet złożone geowizualizacje funkcjonują jako aplikacje internetowe, do których dostęp odbywa się poprzez stronę internetową. Cechują się dużym zróżnicowaniem funkcjonalności i form prezentacji danych, oferując także możliwość samodzielnego dopasowania elementów interfejsu, np. jak w narzędziu GeoWizard opracowanym na podstawie GAV Toolkit (Jern i współautorzy 2007) lub opracowaniu autorstwa I. Dobraja, M.-J. Kraak i Y. Engelhardt (2018) oraz I. Dobraja i M.-J. Kraak (2020), w którym elementy interfejsu są dostosowywane do rodzaju operacji wykonywanych przez użytkowników. Interfejsy tego opracowania pokazane na ryc. 2.5 mają za zadanie wspomóc kolejno: przegląd danych (ryc. $2.5 \mathrm{~A}$ ), analizę wybranego aspektu (ryc. $2.5 \mathrm{~B}$ ) oraz pozyskanie konkretnych informacji (ryc. $2.5 \mathrm{C}$ ) na temat połączeń między lotniskami.

Geowizualizacje wieloelementowe mogą również służyć jako narzędzie do analiz danych czasowo-przestrzennych, co jest obecnie ważnym wyzwaniem w obliczu wielkich zbiorów danych (Wu i współautorzy 2017; 2020). Przykładem wykorzystania geowizualizacji wieloelementowej do analizy dużych zbiorów danych jest badanie (Yusof i współautorzy 2016). Autorzy użyli tego typu opracowania do skutecznej analizy danych na temat kierunku i siły wiatru mierzonych co godzinę przez 10 lat na 29 stacjach klimatologicznych w Holandii.

Jednakże, mimo rewolucji technologicznej skutkującej relatywną łatwością opracowania i udostępniania wieloelementowych narzędzi geowizualizacji, idea, jaka stoi za "logiczną konstrukcją" tego typu opracowań, nie zmienia się od początku ich powstania w latach dziewięćdziesiątych ubiegłego wieku. 

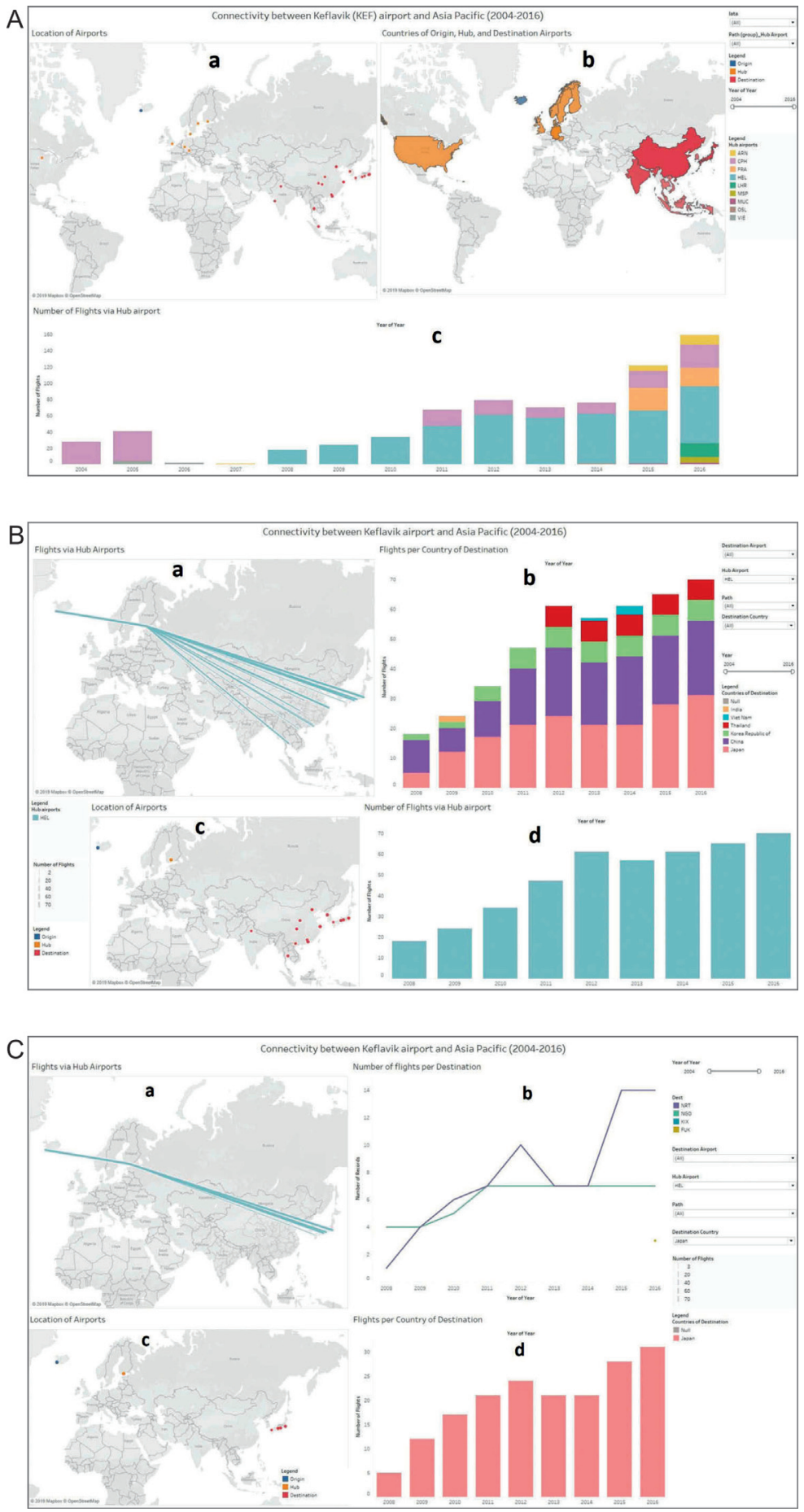

Rycina 2.5. Różne elementy interfejsu tego samego narzędzia wieloelementowego w zależności od rodzaju operacji realizowanej przez użytkownika

Źródło: I. Dobraja i M.-J. Kraak (2020) 


\subsection{Geowizualizacje wieloelementowe jako opracowanie wiralowe}

Przydatność geowizualizacji wieloelementowych pokazały miesiące pierwszego półrocza 2020 roku, w trakcie zmagania się ze światową pandemią wirusa COVID-19. W tym czasie popularnym narzędziem do śledzenia rozwoju pandemii stała się aplikacja COVID-19 Dashboard opracowana przez zespół z Uniwersytetu Johna Hopkinsa (2020), pokazana na ryc. 2.6. Opracowanie to składa się z kilku modułów, które prezentują dane w różnej postaci (Dong, Du i Gardner 2020). W domyślnych ustawieniach interfejs składa się z pięciu okien, przy czym głównym modułem, zajmującym najwięcej miejsca i umieszczonym w środkowej części ekranu, jest mapa tematyczna, na której metodą kartodiagramu kołowego skokowego pokazana jest liczba potwierdzonych przypadków. Te same dane przedstawione są w formie tabelarycznej oraz jako wykres kropkowy. Uzupełnieniem są sumaryczna liczba zgonów w poszczególnych państwach, a także bardziej szczegółowe statystyki dla poszczególnych stanów USA (liczba zrealizowanych testów oraz liczba osób hospitalizowanych). Narzędzie pozwala, po zmianie ustawień wyświetlania, eksplorować inne dane, na przykład o liczbie przypadków wyzdrowień, liczbie notowanych przypadków zakażenia każdego dnia czy też wskaźnik śmiertelności.

Opracowanie to zostało określone przez redakcję „Nature” (Perkel 2020; Zastrow 2020) mianem „wiralowego”2. Z kolei w czasopiśmie "Science" nazwano tę aplikację „najbardziej popularnym na świecie narzędziem do śledzenia pandemii koronawirusa" (Kaiser 2020). Strona internetowa narzędzia osiągała w kwietniu 2020 roku ponad miliard odsłon dziennie. Opracowanie to stało się jednocześnie najbardziej wiarygodnym źródłem informacji o przypadkach koronawirusa.

Zasięg i oddziaływanie omawianego opracowania są nieporównywalne z większością dotychczas funkcjonujących geowizualizacji. Służy ono - oprócz oczywistej funkcji informacyjnej - również jako pomoc w procesach planowania i podejmowania decyzji. Przyczynia się także do popularyzacji geowizualizacji, w tym także w postaci geowizualizacji wieloelementowych. Jednocześnie wykazuje ich przydatność nie tylko dla specjalistów, w tym tych reprezentujących kartografię, ale również dla dużo szerszego grona odbiorców.

Pojawienie się tak popularnego wieloelementowego narzędzia geowizualizacji sprawia, że problem oceny użyteczności rozwiązań tego typu

2 Jak podaje Słownik Języka Polskiego, wiral to „treść (np. filmik, zdjęcie, slogan), która bardzo szybko rozprzestrzenia się w internecie" (Słownik Języka Polskiego 2020). 


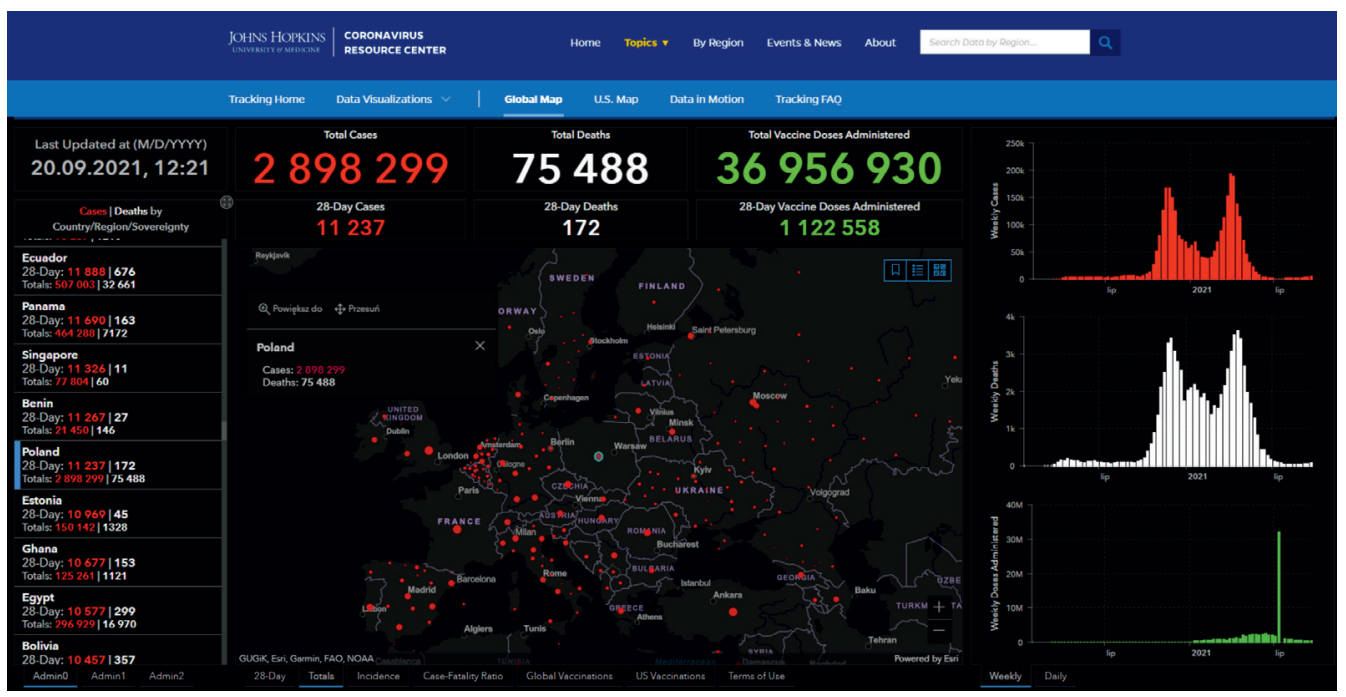

Rycina 2.6. Graficzny interfejs użytkownika popularnego w 2020 roku wieloelementowego narzędzia geowizualizacji

Źródło: COVID-19 Dashboard by the Center for Systems Science and Engineering (CSSE) at Johns Hopkins University (2020)

staje się szczególnie aktualny. Wynika stąd potrzeba poznania sposobu pracy użytkowników z geowizualizacjami wieloelementowymi, by jak najlepiej określić sposób ich optymalnego projektowania.

\subsection{Potrzeba badań użyteczności geowizualizacji wieloelementowych}

Geowizualizacje wieloelementowe mają swoje ważne miejsce w sześcianie użytkowania map (ryc. 2.2), jednak ich przydatność - a w konsekwencji ich rozpowszechnienie - zależy od właściwego ich zaprojektowania. Z pewnością geowizualizacje wieloelementowe oferują nowe możliwości, ale jednocześnie nie można zapominać o ograniczeniach, jakimi może skutkować decyzja o ich użyciu.

Przede wszystkim, geowizualizacje wieloelementowe mogą być zbyt złożone, co powoduje, że użytkownicy mogą się łatwo do nich zniechęcić (Baldonado, Woodruff i Kuchinsky 2000; Andrienko i Andrienko 2006b). Przy czym złożoność geowizualizacji wieloelementowych odnosi się do obu rodzajów złożoności wyróżnionych przez W. Żyszkowską (1993): zarówno złożoności wizualnej (z powodu jednoczesnej widoczności kilku modułów), 
jak i złożoności pojęciowej (gdyż najczęściej opracowania te prezentują dane wielozmienne). Wprawdzie wachlarz rozwiązań projektowych jest nieograniczony, jednak możliwości poznawcze użytkowników - wprost przeciwnie. Jest to zagadnienie o tyle aktualne, że nieustannie pojawiają się nowe, coraz bardziej wysublimowane lub zaawansowane sposoby wizualizacji danych, w tym również danych przestrzennych (Griffin i Fabrikant 2012). Potencjalni użytkownicy mogą niekiedy zrezygnować z ich wykorzystania, mimo że udostępniają wiele pomocnych rozwiązań, być może niedostępnych w innych bardziej popularnych, „prostszych” opracowaniach. Wobec coraz większego rozpowszechnienia geowizualizacji wieloelementowych dużego znaczenia nabiera poznanie i zrozumienie sposobu ich użytkowania. Badania porównujące i oceniające narzędzia geowizualizacji poprzez poznanie sposobu pracy użytkowników w trakcie rozwiązywania różnego rodzaju zadań są zalecane przez autorów (np. Slocum i współautorzy 2001 ; 2005) jako prowadzące do wartościowych wniosków.

Praca z geowizualizacjami wieloelementowymi wiąże się niewątpliwie z wysiłkiem intelektualnym. M.Q.V. Baldonado, A. Woodruff i A. Kuchinsky (2000) wymieniają następujące czynniki, które mogą powodować, że ten wysiłek się zwiększa:

- czas i koszt nauki narzędzia,

- ograniczona pojemność pamięci roboczej użytkownika w czasie analizy danych wieloatrybutowych,

- wysiłek intelektualny niezbędny do porównania informacji między modułami,

- wysiłek intelektualny niezbędny do zmiany kontekstu podczas pracy z różnymi metodami prezentacji danych.

Każdy z tych czynników może wpłynąć negatywnie na doświadczenie użytkownika $w$ trakcie pracy $z$ wieloelementowym narzędziem geowizualizacji. Potrzeba uwzględnienia oczekiwań i możliwości użytkowników w trakcie opracowania geowizualizacji wieloelementowych sprawia, że warto odwołać się do projektowania zorientowanego na użytkownika (ang. user-centred design) (Norman i Draper 1986; Norman 1988). Podejście to uwzględnia wieloetapowe projektowanie i ocenę narzędzia w trakcie jego opracowania.

T. Slocum i współautorzy (2001) rekomendowali podejście opisane przez J.L. Gabbarda, D. Hixa i J.E. Swana (1999) jako ujęcie potencjalnie wartościowe dla narzędzi geowizualizacji. Podejście to zastosowali również w praktyce T. Slocum i współautorzy (2003). Jego istotą jest iteracyjny system pracy, realizowany poprzez cztery etapy opracowania narzędzia: 
1) analizę potencjalnych zadań przed opracowaniem narzędzia (zastosowane np. w badaniu A. Robinsona i współautorów 2005),

2) ocenę narzędzia przez ekspertów, czyli profesjonalistów z zakresu użyteczności,

3) sprawdzenie narzędzia z grupą docelowych użytkowników w celu przetestowania funkcji narzędzia,

4) ocenę narzędzia w trakcie jego wykorzystania do rozwiązania różnych, wybranych zadań.

Ostatni, czwarty etap wymaga opracowania listy zadań, jakie potencjalni użytkownicy mogą rozwiązywać za pomocą narzędzia. Taka lista jest przygotowywana z wykorzystaniem klasyfikacji zadań. Zaproponowano wiele tego typu klasyfikacji zadań i operacji realizowanych w trakcie pracy z (geo)wizualizacjami. Klasyfikacje były opracowywane w różnym celu i podkreślają różne aspekty pracy z geowizualizacjami. Są one ze sobą w pewnym zakresie powiązane (Roth 2012). Na podstawie analizy dziewięciu klasyfikacji R. Roth (2012) stwierdzit, że zadaniami najczęściej wymienianymi w klasyfikacjach są „identyfikacja” oraz „porównanie", często występującymi operacjami są również "grupowanie" oraz „znalezienie zależności”.

Takie klasyfikacje były niejednokrotnie wykorzystywane w badaniach użyteczności. Przykładowo, E.L. Koua, A.M. MacEachren i M.-J. Kraak (2006) porównali użyteczność kilku metod prezentacji do realizacji zadań określonych w klasyfikacji autorstwa M.X. Zhou i S.K. Feiner (1998). Z kolei, A. Çöltekin i współautorzy (2009) wykorzystali różnego rodzaju zadania do porównania dwóch wersji mapy interaktywnej różniących się graficznym interfejsem użytkownika, ale o porównywalnym poziomie informacyjności. Wykorzystano zadania polegające na identyfikacji, określeniu położenia oraz znalezieniu zależności. Zadania te były również porządkowane pod względem złożoności. A. Çöltekin (2019), wykorzystując klasyfikację autorstwa L. Knapp (1995), wyróżniła zadania o niskim poziomie złożoności (które również uporządkowała pod względem stopnia trudności), takie jak identyfikowanie, lokalizowanie, porównanie, zapamiętanie, oraz zadania złożone (interpretacja, eksploracja, znajdowanie drogi).

Przydatność projektowania zorientowanego na użytkownika na gruncie kartograficznym została szeroko omówiona przez R.E. Rotha (2019). Wskazał on osiem aspektów (oznaczonych na rycinie 2.7 na fioletowo, literami A-H), w jakich to podejście może wzbogacić dyscyplinę i badania kartograficzne. Wskazane przez niego aspekty mają charakter teoretyczny (np. analiza luk w dyscyplinie), metodyczny (np. nowe metody badawcze), jak i praktyczny (np. nowe mapy oraz wizualizacje). 


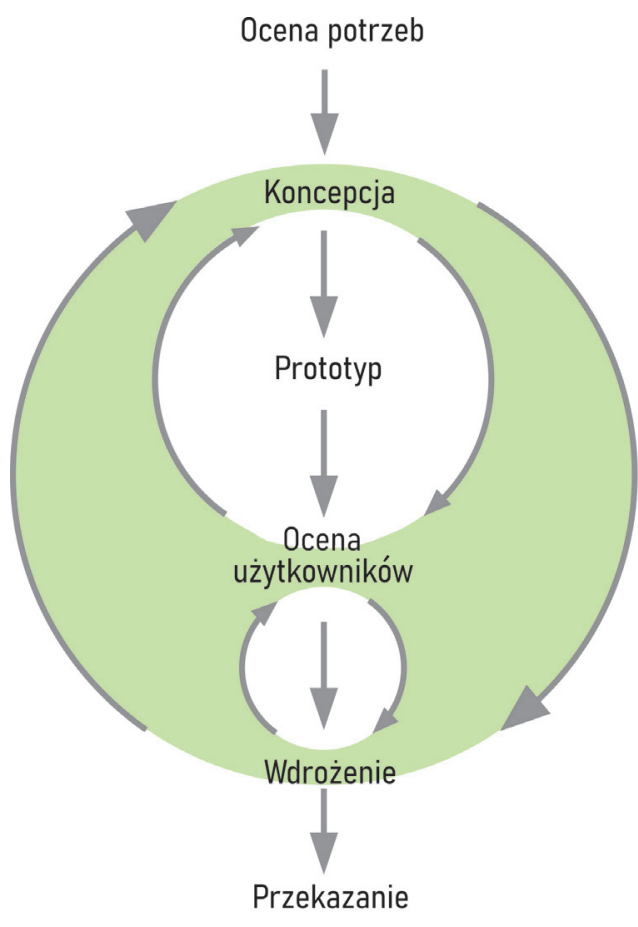

A. Analiza luk

w dyscyplinie
B. Nowe metody badawcze

C. Usprawnienie projektowania zorientowanego na użytkownika

D. Wgląd w projektowanie

E. Przykłady badań projektowania zorientowanego na użytkownika

F. Nowatorskie mapy i wizualizacje

G. Eksperymenty kontrolowane

H. Nowe spojrzenie na problemy geograficzne

Rycina 2.7. Aspekty (A-H) wskazane przez R.E. Rotha (2019), które mogą wzbogacić kartografię dzięki zastosowaniu badań zorientowanych na użytkownika

\subsection{Zagadnienia podejmowane w dotychczasowych badaniach empirycznych geowizualizacji wieloelementowych}

Prowadzone dotychczas badania empiryczne nad sposobem pracy użytkowników geowizualizacji wieloelementowych (np. Andrienko i współautorzy 2002; Robinson i współautorzy 2005; Marsh, Dykes i Attilakou 2006; Demšar 2007; Bhowmick i współautorzy 2008; Robinson i współautorzy 2017b; Pezanowski i współautorzy 2018; Li i współautorzy 2019; Zuo, Ding i Meng 2020) pozwoliły wykazać, że są to wartościowe opracowania, które mogą być użyteczne w różnych kontekstach. I.D. Bishop i współautorzy (2013) analizowali najbardziej przydatne dla decydentów sposoby prezentacji danych dotyczących zmian klimatu. Co ważne, badani wskazali, że wartościowa dla nich jest jednoczesna widoczność różnych form prezentacji - zamiast jednej wybranej. 
Wiele badań miało na celu ocenę użyteczności konkretnych narzędzi opracowanych do konkretnego zastosowania. A.C. Robinson i współautorzy (2017b) zaprezentowali aplikację STempo służącą prezentacji danych z mediów społecznościowych w celu określenia rozmieszczenia zdarzeń, na przykładzie danych dotyczących działań militarnych w Syrii. Autorzy w wyniku badań z udziałem użytkowników wskazali, w jakim zakresie narzędzie powinno być poprawione i uzupełnione, by lepiej spełniać swoje funkcje. Podobnie S. Pezanowski i współautorzy (2018) przedstawili wieloelementowe narzędzie geowizualizacji SensePlace3 jako przykład wykorzystania danych z medium społecznościowego, jakim jest Twitter, a przeprowadzone badania jego użyteczności pozwoliły wskazać aspekty wymagające ulepszeń. Aplikacja zaproponowana przez K. Nazemi i D. Burkhardta (2019) prezentowała dane dotyczące mobilności i transportu, a jej celem było przede wszystkim wspieranie użytkowników w operacjach porównywania i analiz. Ponadto J. Li i współautorzy (2019) pokazali możliwości włączenia zmiennej czasu do wieloelementowej geowizualizacji. Zaprezentowali oni opracowanie przedstawiające występowanie rozmieszczenia zjawisk w dwóch miejscach przed, w trakcie i po wybranym momencie czasowym. Również C. Zuo, L. Ding i L. Meng (2020) przeprowadzili empiryczną ewaluację wieloelementowej geowizualizacji (ryc. 2.8), wykazując, że jest to skuteczne narzędzie w eksploracji złożonych danych przez decydentów. Jednocześnie autorzy wskazali na potrzebę badań porównujących, jak sposób projektowania interfejsu wieloelementowej geowizualizacji wpływa na pracę użytkowników.

Geowizualizacje wieloelementowe to narzędzia przede wszystkim przeznaczone do budowania wiedzy eksperckiej oraz podejmowania decyzji przez decydentów (Bhowmick i współautorzy 2008). Rzadkim przypadkiem są badania geowizualizacji do szybkiego poznawania danych (Yalcin, Elmqvist i Bederson 2018). Autorzy przedstawili geowizualizację wieloelementową o nazwie Keshif. Jednak chociaż zaznaczyli oni, że jest to opracowanie dla osób bez doświadczenia w używaniu tego typu opracowań, to jednak przed empiryczną oceną jego użyteczności uczestnicy byli przeszkoleni w zakresie sposobu funkcjonowania aplikacji w postaci prezentacji wideo, slajdów, sesji z pytaniami i odpowiedziami oraz próbnego użycia narzędzia. Dopiero wtedy przystąpili do testowania jego użyteczności.

Innym wątkiem badań empirycznych geowizualizacji wieloelementowych była ocena zastosowanych w nich metod prezentacji. Odwołując się do opinii S. Wehrenda i C. Lewisa (1990), że każda forma wizualizacji ma właściwą sobie strukturę i podkreśla inne aspekty prezentowanych danych, a zatem może lepiej wspierać różne operacje, podejmowano próby 

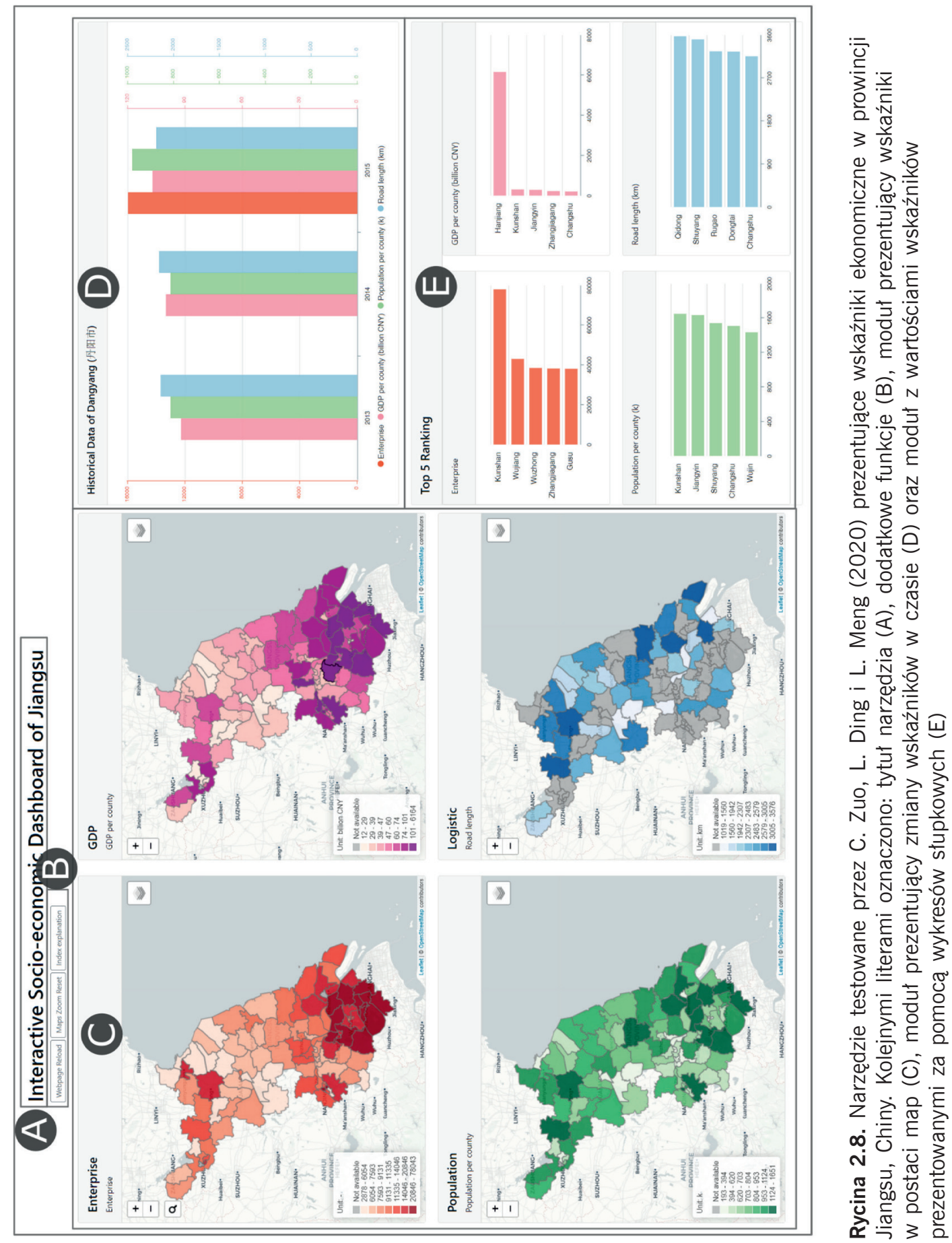
oceny rozmaitych metod prezentacji pod kątem przydatności do różnego typu zadań. Oceny te były prowadzone właśnie w kontekście przydatności tych metod do wykorzystania w geowizualizacjach wieloelementowych. R.M. Edsall (2003) wykazał, że użytkownicy z taką samą skutecznością, czyli poprawnością, odpowiadali na pytania dotyczące statystycznych charakterystyk zdrowia za pomocą zarówno wykresu osi równoległych, jak i wykresu punktowego. Mimo porównywalnej poprawności odpowiedzi użytkownicy uznali wykres osi równoległych za trudny do użytkowania. Również E.L. Koua, A.M. MacEachren i M.-J. Kraak (2006) porównywali przydatność różnych form w celu wyboru optymalnej metody do wykorzystania w geowizualizacjach wieloelementowych. Wykazali oni, że wykres osi równoległych okazał się trudnym i nieprzydatnym rozwiązaniem dla większości testowanych operacji. Zwrócili jednocześnie uwagę, że trudność wynikała z małej klarowności obrazu spowodowanej przez nakładanie się wielu linii na wykresie. Wyniki tych badań wykorzystali przy opracowaniu prototypu wieloelementowego narzędzia geowizualizacji (Koua i Kraak 2008).

Użyteczność różnych metod wizualizacji była również weryfikowana empirycznie, gdy testowane metody były widoczne jednocześnie w różnych modułach tego typu opracowania. G.J. Convertino i współautorzy (2003) porównali zachowanie użytkowników trzech dwuelementowych, ale odmiennie zaprojektowanych narzędzi geowizualizacji o bardzo ograniczonej stronie graficznej, zbudowanych z: (1) dwóch wykresów osi równoległych, (2) wykresu osi równoległych i wykresu punktowego oraz (3) wykresu osi równoległych i mapy. Okazało się, że badani korzystający z dwóch wykresów osi równoległych udzielili najwięcej błędnych odpowiedzi i jednocześnie ocenili zadania jako najtrudniejsze. Również w innym badaniu autorzy weryfikowali, czy zestawienie wykresu osi równoległych z mapą tematyczną pozwala na efektywną eksplorację danych wielotematycznych (Opach i Rød 2014). Autorzy wykazali, że to zestawienie form prezentacji może ułatwić wgląd $w$ dane oraz zrozumienie charakterystyk prezentujących podatność środowiska na klęski żywiołowe. Również I. Kveladze, M.-J. Kraak i C. van Elzakker (2017) podjęli się próby zweryfikowania, jak rozmaite formy prezentacji (mapa, sześcian czasowo-przestrzenny, dwa wykresy) są pomocne $w$ realizacji różnego typu zadań w kontekście wieloelementowej geowizualizacji. Wyniki badania (o niedużym zakresie, bo z udziałem pięciu badanych) wykazały, że testowane formy były pomocne w różnego typu operacjach, a interaktywne połączenie między modułami znacznie ułatwiło realizację zadań. Autorzy podkreślili jednocześnie potrzebę odpowiedniego przygotowania użytkowników do pracy z tego typu opracowaniami. 
Badania geowizualizacji wieloelementowych są więc aktualnym problemem, podejmowanym zarówno na płaszczyźnie geowizualizacji, jak i szeroko pojętej wizualizacji różnorodnych danych o różnej tematyce. Każde z tych badań rozszerza spojrzenie na złożone zagadnienia geowizualizacji wieloelementowych. Szczególnie interesujące są te badania, które wykraczają poza samą ocenę użyteczności konkretnego narzędzia oraz poszukiwanie błędów i niedociągnięć w konkretnym projekcie. Dzięki temu, że wyciągane są z nich wnioski o charakterze ogólnym, mogą mieć zastosowanie $w$ formułowaniu wiedzy na temat funkcjonowania geowizualizacji wieloelementowych, sposobu pracy ich użytkowników, a następnie także ogólnych zasad projektowania tego typu opracowań.

\subsection{Redundancja w kontekście geowizualizacji wieloelementowych}

\subsubsection{Definicja i poglądy na redundancję}

Redundancja, czyli powtórzenie treści, powtórzenie danych, stanowi rozwiązanie oceniane przez kartografów w różny sposób. Redundancja definiowana jest przez Stownik Języka Polskiego jako „nadmiar w stosunku do tego co niezbędne; cecha komunikatu zawierającego więcej informacji, niż minimum niezbędne do przekazania treści". W odmiennych kontekstach może przynosić pozytywne lub negatywne konsekwencje dla czytelności i efektywności opracowania. W kontekście geowizualizacji wieloelementowych redundancja nie podlegała jednak szerszym rozważaniom teoretycznym ani ocenie empirycznej. Z racji częstego stosowania redundancji w tego typu opracowaniach warto $w$ tym miejscu bliżej przyjrzeć się temu zagadnieniu, by wskazać wpływ jej przyjęcia na sposób pracy użytkowników. Pozwoli to na sformułowanie rekomendacji w zakresie stosowania redundancji w kontekście danych prezentowanych w różnych modułach. Jak określił J.C. Roberts (2008), możliwych jest kilka scenariuszy zróżnicowania danych źródłowych pomiędzy modułami geowizualizacji wieloelementowych. Obejmują one następujące opcje (ryc. 2.9):

1) każdy moduł prezentuje te same dane, ale w inny sposób (ryc. 2.9 A),

2) jeden moduł jest wycinkiem danych prezentowanych $w$ innym module (ryc. 2.9 B), np. jeden moduł może pokazywać ceny towarów w wybranym okresie, w innym module zaś prezentowane są ceny tych towarów tylko jednej firmy w danym okresie,

3) jeden moduł prezentuje zagregowane wartości elementów prezentowanych oddzielnie w kolejnym module (ryc. 2.9 C), w jednym module 
mogą być pokazane średnie ceny w restauracjach na danym obszarze, w drugim zaś module - położenie poszczególnych restauracji,

4) w dwóch modułach prezentowane są inne dane, choć dobrane celowo i charakteryzujące to samo zagadnienie (ryc. 2.9 D), np. w autorskim narzędziu Slingsby i współautorzy (2014) przedstawili wyniki badań wśród mieszkańców badanego obszaru i w kolejnych modułach pokazali: w pierwszym - odpowiedzi na wybrane pytania, w drugim - odpowiedzi dotyczące dostępu do wybranych usług, w trzecim zaś - charakterystykę demograficzną badanych.

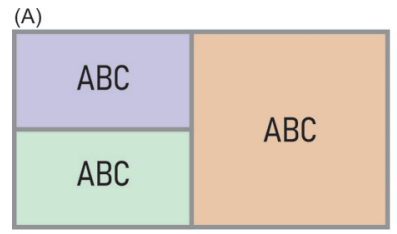

(c)

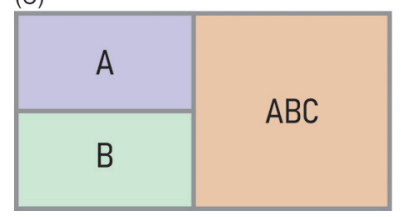

(B)

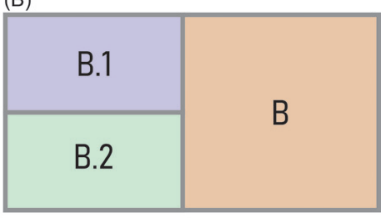

(D)

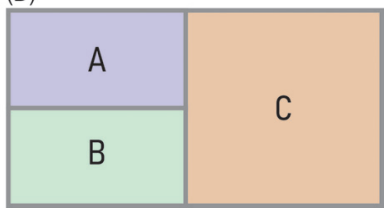

Rycina 2.9. Sposoby różnicowania danych źródłowych między modułami

Szczególnie interesującym przypadkiem jest sytuacja wskazana przez J.C. Robertsa (2008) i przedstawiona powyżej w pierwszym punkcie: poszczególne okna opracowania prezentują te same dane, lecz w różnej formie. Mamy tu zatem do czynienia z redundancją treści. Warto rozważyć, czy takie powtórzenie danych jest rozwiązaniem efektywnym, czy też nie. Istnieje bowiem ryzyko, że z racji powtórzenia tych samych danych za pomocą różnych metod prezentacji mamy do czynienia z nadmiernym rozbudowaniem zarówno treści, jak i formy, co zamiast pomóc, będzie przeszkadzało z uwagi na zbytnią złożoność interfejsu.

W kartografii termin redundancji jest ugruntowany i określany najczęściej w kontekście teorii informacji. A.A. Moles (1971) powiązał redundancję ze zrozumiałością przekazu. Stwierdził, że zrozumiałość jest funkcją względnej nadwyżki znaków użytych w przekazie w stosunku do minimum liczby znaków, niezbędnie koniecznych, aby zapewnić poprawny odbiór informacji. Jak określa R. Ogrissek (1970; 1998), w ogólnym użyciu oznacza rozwlekłość w przeciwieństwie do zwięzłości i ścisłości. L. Ratajski (1989) określił redundancję jako „rozwlekłość wyrażania i nadmiar oznaczeń utrudniające czytanie mapy" (s. 18). Wyróżnia on 
trzy rodzaje redundancji: merytoryczną, sygmatyczną i syntaktyczną. Redundancja merytoryczna (ryc. 2.10 A), zwana przez R. Ogrisska (1970) semantyczną, występuje w przypadku zbyt rozbudowanej treści mapy w stosunku do jej tematu. Prezentowane są informacje ogólne, niezwiązane bezpośrednio z tematem, a jednocześnie znane odbiorcy. Redundancja sygmatyczna (ryc. 2.10 B) ma miejsce, gdy są użyte nieodpowiednie środki przekazu informacji, nieodpowiadające treści, na przykład kiedy zastosowana jest niewłaściwa metoda prezentacji lub kiedy znaki są zbytnio rozbudowane. Z kolei redundancja syntaktyczna (ryc. 2.10 C) występuje, gdy jest za wiele znaków (np. za długie określenia w legendzie) lub kiedy znaki nachodzą na siebie. Co ważne, L. Ratajski (1989) tylko ostatnią z wyróżnionych rodzajów redundancji ocenił jako zawsze niekorzystną, jednocześnie zaznaczył, że w pewnych przypadkach redundancja merytoryczna oraz sygmatyczna mogą w ograniczonym rozmiarze spełniać rolę pozytywną.

Z kolei R. Ogrissek (1983) określił redundancję w kontekście teorii informacji, opisując ją jako te elementy, które nie dostarczają nowych informacji lub przynajmniej nie zmieniają znacząco już przekazanej informacji. Jest to ta część przekazu, która nie jest niezbędna dla procesów informacyjnych, ponieważ użytkownik jest w stanie ją uzupełnić. Zatem ocena redundancji zależy również od wiedzy użytkownika mapy (Ogrissek 1970). Dlatego mówi się o redundancji informacyjnej. Wyróżnia jednak redundancję przydatną i redundancję pustą. Redundancja przydatna obejmuje te elementy przekazu, które pomagają zachować lub odtworzyć informację trudniej dostępną lub utraconą z innego powodu. W przypadku mapy wskazuje na realizację tej funkcji poprzez strzałkę spływu wód rysowaną wzdłuż rzeki, pomimo że tę informację można odczytać z wartości kolejnych poziomic, które dana rzeka przecina. Z kolei redundancja pusta jest określana przez autora jako rozwiązanie negatywne, które należy ograniczać. Polega na prezentacji elementów, które można pominąć bez utraty informacji, ale których nie można użyć do zachowania rzeczywistej treści informacji w przypadku zakłócenia w przetwarzaniu informacji. Zatem w XX wieku, w odniesieniu do klasycznych map, autorzy w różny sposób postrzegali i oceniali redundancję.

Obecnie spojrzenie na redundancję na mapach również nie jest jednoznaczne (Tyner 2010). Autorzy są zgodni, że redundancja ma miejsce na mapie m.in. w przypadku, gdy użyje się dwóch zmiennych graficznych czy dwóch form prezentacji do przedstawienia tych samych danych. Część autorów uważa, że rozwiązanie to „wzmacnia” przekaz i ułatwia czytanie mapy oraz jej zrozumienie. Zalety stosowania redundancji 

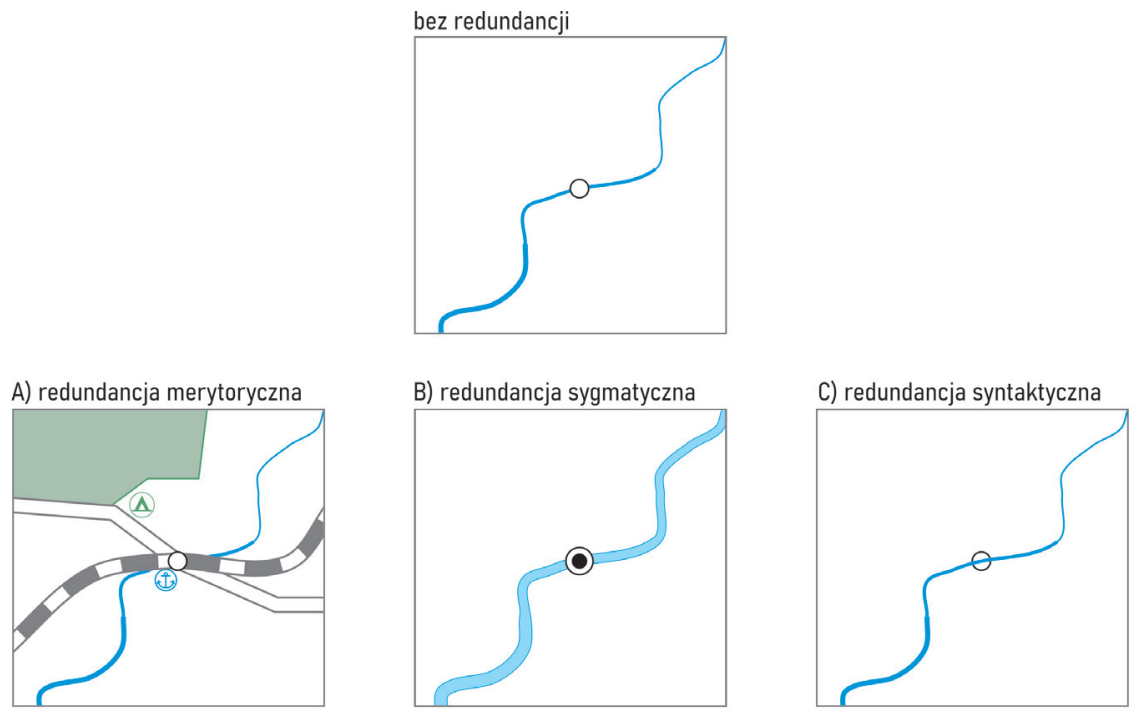

Rycina 2.10. Przykłady redundancji na mapach według L. Ratajskiego (1989)

wskazuje wielu autorów (Slocum i współautorzy 2005; Bertin 1983), uzasadniając, że poprzez użycie dwóch zmiennych graficznych do prezentacji tych samych informacji akcentuje się wybrane, najważniejsze zagadnienie. Z kolei inny pozytywny aspekt stosowania redundancji za pomocą zmiennych wielkości i barwy wskazuje C. Ware (2004), twierdząc, że użytkownicy o niepoprawnej percepcji kolorów (różne odmiany daltonizmu dotyczą około 10\% mężczyzn oraz 1\% kobiet) mają możliwość poprawnego odczytania mapy, nawet jeśli zastosowano skalę barwną nieczytelną dla daltonistów. Tacy użytkownicy mogą czytać wielkość, pomijając nieczytelną dla nich zmienną barwy. Redundancja znajduje również zastosowanie na mapach prezentujących dane wielozmienne. Złożoność takich map sprawia, że w celu zwrócenia uwagi użytkownika na istotne kwestie można wyeksponować te elementy treści, które są zasadnicze dla zrozumienia prezentowanego zagadnienia (Nelson 2020). Jak określa T. Zarycki (2002), zmniejszając redundancję, doprowadza się do większego wysiłku intelektualnego użytkownika mapy.

Redundancja bywa uważana również za wadę mapy, przejawiającą się w nadmiarze oznaczeń i utrudnianiu czytania mapy (Ratajski 1989). W konsekwencji powoduje ona znudzenie i osłabia uwagę (Zarycki 2002). Zastosowanie redundancji może również być mylące dla użytkowników, którzy mogą błędnie założyć, że kolejna zmienna graficzna została użyta do zakodowania innych danych. To w konsekwencji może obniżać użyteczność opracowań kartograficznych (Tyner 2010). 


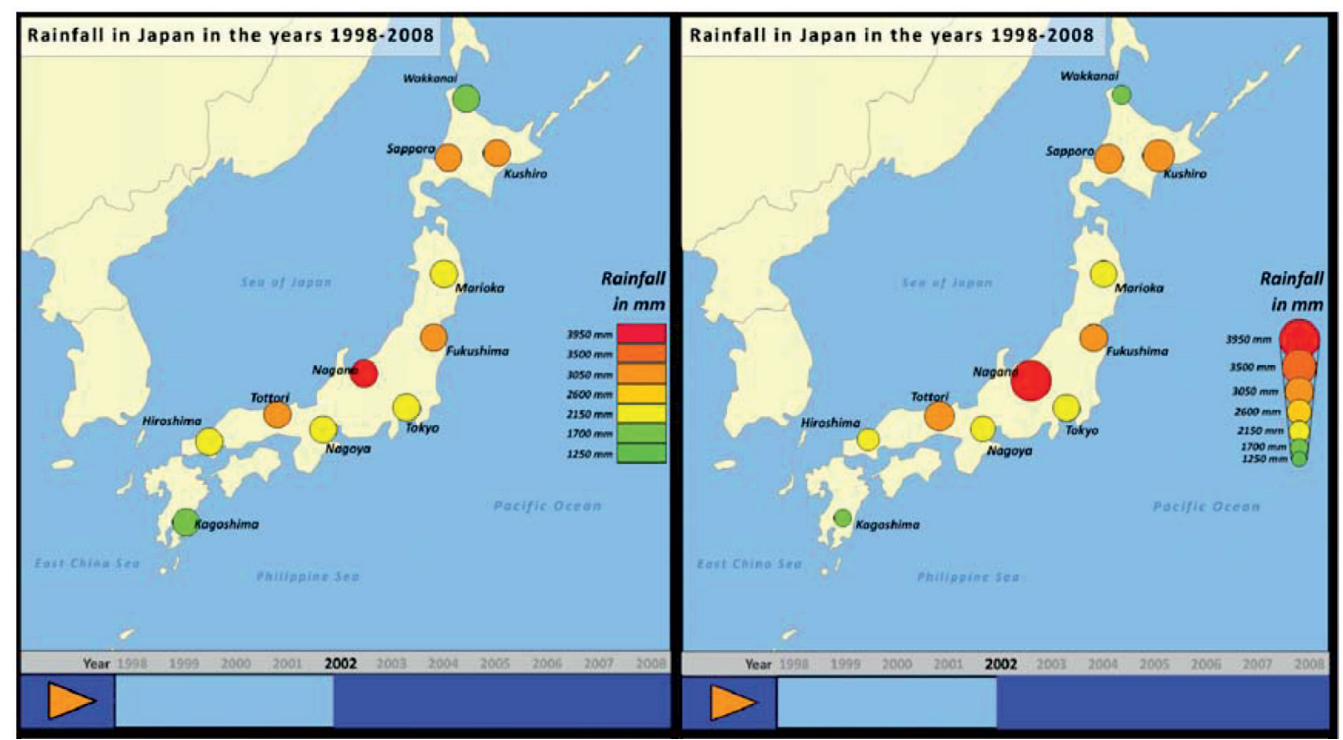

Rycina 2.11. Mapy animowane wykorzystane w badaniach przez P. Cybulskiego i B. Medyńską-Gulij (2018): bez redundancji (po lewej) oraz z redundancją (po prawej: mapa opracowana z wykorzystaniem prezentacji tej samej informacji za pomocą wielkości i barwy diagramów kołowych)

Badania empiryczne są z pewnością ważne dla oceny przydatności redundancji w prezentacji kartograficznej. M. Dobson (1983) zweryfikował przydatność redundancji w kartodiagramie kartogramicznym. Testował on empirycznie mapę, w której zarówno wielkość diagramów, jak i ich wypełnienie z użyciem zbieżnej skali szarości prezentowały te same dane. Okazało się, że takie rozwiązanie skutkowało wzrostem poprawności odpowiedzi i jednocześnie skróceniem czasu w porównaniu do mapy bez zastosowania redundancji. W kontekście map animowanych analogiczne badania przeprowadzili P. Cybulski i B. Medyńska-Gulij (2018). Autorzy użyli zmiennych graficznych wielkości oraz barwy do zakodowania danych o odniesieniu punktowym (wielkość opadów atmosferycznych, ryc. 2.11), liniowym (poziom wody w rzece) oraz powierzchniowym (stopa bezrobocia) na mapach animowanych, w celu weryfikacji, czy redundancja może poprawić percepcję zmian w porównaniu do map animowanych, które prezentują te dane przy użyciu jednej zmiennej. Okazało się, że zastosowanie redundancji znacząco zwiększyło poprawność określania na mapie miejsc występowania wartości ekstremalnych prezentowanych zjawisk oraz skróciło czas odpowiedzi w przypadku większości testowanych map. Natomiast w badaniach mojego współautorstwa (Korycka-Skorupa 


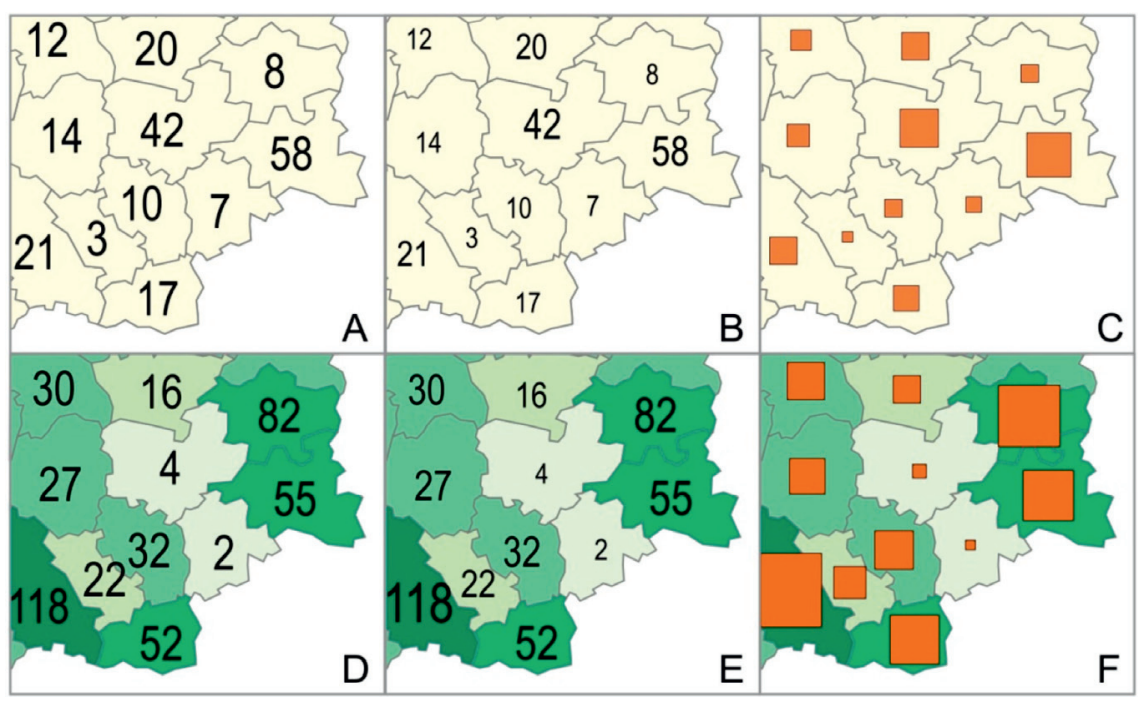

Rycina 2.12. Redundancja na mapach statystycznych (w dolnym rzędzie) skutkowała wyższą poprawnością i krótszym czasem odpowiedzi w porównaniu do map bez redundancji (w górnym rzędzie)

Źródło: J. Korycka-Skorupa i I. Gołębiowska (2020)

i Gołębiowska 2020) z redundancją mieliśmy do czynienia przy kartogramicznej prezentacji danych związanych z infrastrukturą turystyczną: na rozkolorowanych polach odniesienia pokazano odpowiadające im wartości liczbowe (ryc. 2.12 D, E) lub diagramy (ryc. 2.12 F) prezentujące te same dane, co wykorzystany jako tło kartogram. Okazało się, że taki zabieg powodował istotny wzrost poprawności odpowiedzi oraz obniżenie czasu potrzebnego do jej udzielenia w porównaniu do map, które prezentowały te same dane bez zastosowania redundancji (ryc. $2.12 \mathrm{~A}-\mathrm{C}$ ).

Opisane powyżej badania wykazały, że redundancja może być korzystna dla użyteczności mapy. Z pewnością są pewne granice jej stosowania, lecz - mimo podjętych prób (Shortridge i Welch 1982) - nie zostały one jeszcze określone. Z pragmatycznego punktu widzenia wydaje się jednak, że zbytnia złożoność mapy, również w aspekcie graficznym, może skutkować obniżeniem jej użyteczności (MacEachren 1982).

Redundancja w kontekście wieloelementowych geowizualizacji wydaje się zagadnieniem bardziej złożonym niż dotychczas badana redundancja na pojedynczych mapach. Może mieć zastosowanie w różnych aspektach: zarówno w odniesieniu do redakcji pojedynczego modułu geowizualizacji wieloelementowej, np. mapy albo wykresu, jak i w odniesieniu do redakcji 
całości opracowania - całej prezentacji, gdy rozpatrujemy wszystkie jego moduły. Innymi słowy, treść może być powtórzona tylko na mapie, czyli w jednym module geowizualizacji wieloelementowej, jak również powtórzenie treści może mieć miejsce w kilku modułach prezentowanych w obrębie interfejsu tego typu narzędzia. Należy jednak zwrócić uwagę, że $w$ przypadku prezentowania tych samych danych w kolejnych modułach za pomocą różnych form prezentacji z pewnością wzrasta jego złożoność, ale jednocześnie możliwe jest spojrzenie na prezentowane zjawisko z różnych perspektyw. Zatem to powtórzenie może mieć zarówno pozytywne, jak i negatywne konsekwencje. Zagadnienie to nie było jednak dotychczas wystarczająco badane. Ze względu na specyfikę przedmiotu badań, jakim są wieloelementowe geowizualizacje, modyfikacji wymaga sposób analizy redundancji w porównaniu do dotychczasowych badań prowadzonych w odniesieniu do pojedynczych, zazwyczaj statycznych, map.

$W$ przypadku geowizualizacji wieloelementowych redundancja danych stosowana pomiędzy modułami znacząco wpływa na ich złożoność. Dobrym tego przykładem jest, opisane $w$ rozdziale 4.1, narzędzie ViewExposed, w którym wykorzystano tabelę, wykres osi równoległych oraz mapę kartogramiczną. Wspomniane ryzyko zbytniej złożoności może mieć tutaj miejsce i w konsekwencji być powodem obniżenia użyteczności tego opracowania. Redundancja może bowiem spowodować wzrost wysiłku intelektualnego użytkownika, który będzie usiłował przetworzyć i zrozumieć szereg dodatkowych sygnałów, a być może nie wszystkie są niezbędne do zrozumienia prezentowanych treści. Efektywne wizualizacje cechują się możliwie najmniejszym obciążeniem poznawczym, czyli wysiłkiem intelektualnym użytkownika.

Redundancja może wpłynąć na wzrost wysiłku intelektualnego w związku ze zmianą kontekstu (ang. context switching), czyli poznawaniem tych samych danych prezentowanych w różny sposób (Baldonado, Woodruff i Kuchinsky 2000). Istnieje ryzyko, że użytkownicy będą chcieli uniknąć wzrostu obciążenia poznawczego, aby zminimalizować swój wysiłek. Mogą bowiem koncentrować uwagę tylko na jednym elemencie, pomijając inne. W ten sposób unikają obciążenia poznawczego związanego ze zmianą kontekstu, czyli zmianą elementu zawierającego inną formę prezentacji danych. W konsekwencji nie wykorzystają pełnego potencjału wieloelementowego narzędzia geowizualizacji: nie spojrzą na prezentowane dane z różnych perspektyw, co być może pozwoliłoby im na lepsze ich zrozumienie. Wspomniane ryzyko zbytniej złożoności postrzeganej przez użytkowników może stać się również powodem obniżenia użyteczności opracowania, a w konsekwencji doprowadzić nawet do zaniechania korzystania z niego. 
Niektórzy autorzy wykazali, że wydłużenie czasu odpowiedzi z powodu zmiany kontekstu nie musi być istotne (Convertino i współautorzy 2003) i że użytkownicy potrafią integrować informacje pozyskane z różnych modułów wieloelementowego narzędzia geowizualizacji (Opach i Rød 2014). Dotychczasowe badania nie koncentrowały się jednak na problemie redundancji treści w tego typu opracowaniach, nie podejmowano zatem kwestii przydatności jej stosowania, zwłaszcza poprzez weryfikację empiryczną.

\subsubsection{Redundancja a nieprzystępne formy prezentacji treści}

Kolejnym czynnikiem, który może ograniczyć użyteczność geowizualizacji wieloelementowej z redundancją danych, jest zastosowanie formy prezentacji określanej jako niezrozumiała. Użytkownicy, wychodząc z założenia, że $w$ pozostałych elementach są prezentowane te same dane, mogą ograniczyć korzystanie z elementu postrzeganego przez nich jako trudny do zrozumienia lub nawet zrezygnować z niego. Przykładem takiej formy jest wykres osi równoległych (ang. parallel coordinated plot $-P(P)$, pokazany na ryc. 2.13. Jest to forma przedstawienia danych wieloatrybutowych. Na wykresie tego typu prezentowane są różne dane, oznaczone na osiach umieszczonych obok siebie (osie czarne na ryc. 2.13). Ich połączenie skutkuje uzyskaniem pęku linii, które oznaczają kolejne jednostki pomiarowe (np. państwa, miasta), przecinające osie w miejscach odpowiadających wartościom zmiennych (kolorowe linie na ryc. 2.13). Jest to niezwykle „pojemna” forma prezentacji, dająca możliwość jednoczesnego pokazania zarówno dużej liczby jednostek pomiarowych, jak i odnoszących się do nich wielu atrybutów. Odpowiednie uporządkowanie osi daje możliwość zaobserwowania zależności między zmiennymi i grupami jednostek. Przy wizualizacji danych geograficznych nie jest to jednak często stosowany sposób prezentacji, przeważnie z obawy o trudność w jego odbiorze.

Niektóre badania wykazują, że wykres osi równoległych jest oceniany jako rozwiązanie trudne w odbiorze (Convertino i współautorzy 2003; Robinson i współautorzy 2005). Są jednak badania, w których pokazano, że zestawienie wykresu osi równoległych z mapą, na której pokazano te same dane, pomaga w zrozumieniu przedstawianych treści (Edsall 2003; Opach i Rød 2014). Jednak prace dotyczące „naiwnej” kartografii (naïve cartography oraz naïve realism) sugerują, że użytkownicy nie zawsze wiedzą, co jest dla nich najbardziej odpowiednie do rozwiązania danego zadania (Smallman i John 2005; Hegarty i współautorzy 2009). Mając do wyboru kilka opcji, mogą wybierać i korzystać z form prezentacji, 


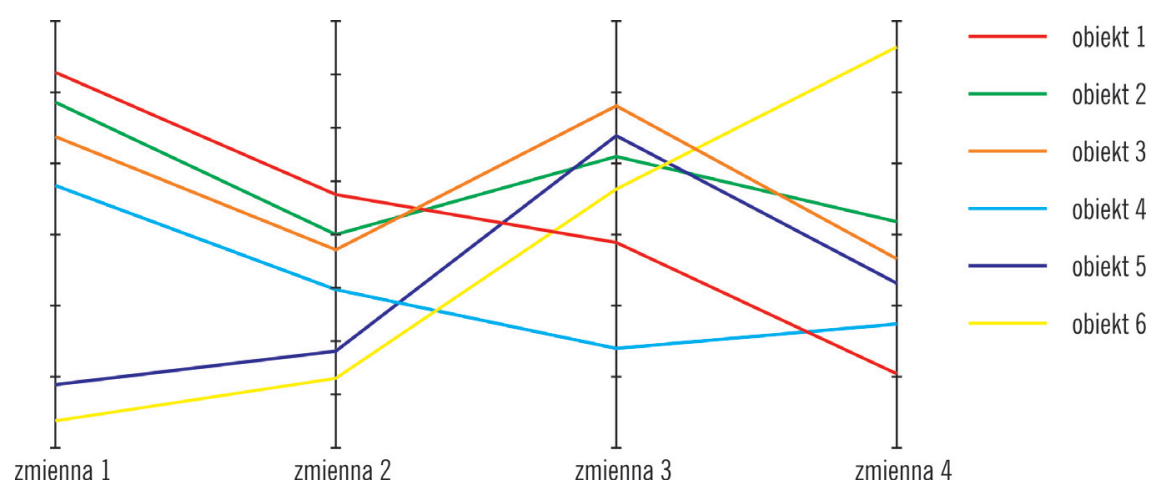

Rycina 2.13. Schemat budowy wykresu osi równoległych

które nie są najbardziej efektywne w danym kontekście (de Mendonça, Alencar i Delazari 2012). W trakcie korzystania z geowizualizacji wieloelementowych nie będą w ten sposób mogli odkryć w pełnym zakresie „bogactwa danych źródłowych”, koncentrując się na metodach, do których się przyzwyczaili, i pomijając rozwiązanie im nieznane (Roberts 2007). Nie wykorzystają więc $w$ pełni zalet geowizualizacji wieloelementowej z powodu unikania jakiegoś modułu, jeśli uznają go za zbyt trudny do korzystania i do zrozumienia. Warto zatem zweryfikować zachowania użytkowników, w sytuacji gdy mają pełną dowolność korzystania z różnych form prezentacji, tych ocenianych jako bardziej przystępne i popularne (np. tabela, kartogram prosty), jak i tych rzadziej stosowanych i nieco bardziej złożonych, do jakich należy wykres osi równoległych.

\subsection{Przystępność geowizualizacji wieloelementowej dla niedoświadczonych użytkowników}

\subsubsection{Potrzeba wsparcia nowych użytkowników}

Pomimo że wykazano, iż geowizualizacje wieloelementowe są wartościowymi narzędziami do różnego typu zadań, N. Andrienko i G. Andrienko (2007) postawili pytanie, dlaczego opracowania te są tak rzadko wykorzystywane i nadal nie są popularne. Ważnym zagadnieniem $w$ tym aspekcie jest charakterystyka użytkowników tych opracowań. Jak stwierdził C. McGuiness (1994), nowe narzędzia wizualizacji są projektowane i użytkowane przez wąskie grono ekspertów. Dopiero druga "generacja” użytkowników może objąć szersze, mniej profesjonalne grono. To szerokie 
grono użytkowników różni się od ekspertów brakiem formalnego przygotowania (Mead 2014). Dlatego projektując nowe narzędzia, trzeba wziąć pod uwagę umiejętności użytkowników. N. Andrienko i współautorzy (2002) wykazali, że kiedy tylko użytkownicy zrozumieją, jak należy pracować z geowizualizacjami wieloelementowymi, mogą sami efektywnie kontynuować pracę. Zatem pomimo że geowizualizacje wieloelementowe wydają się nadal być narzędziami niezbyt często stosowanymi i nowymi dla wielu osób, wydaje się, że wystarczy niewielka pomoc na początku, by umożliwić użytkownikom satysfakcjonującą i efektywną pracę (Harrower, MacEachren i Griffin 2000).

Wspomniany aspekt nauczalności, jako jeden z elementów użyteczności, ma kluczowe znaczenie dla rozpowszechnienia się nowych, nieznanych wcześniej rozwiązań. Niedoświadczeni użytkownicy mogą ich unikać, jeśli przy pierwszym kontakcie uznają, że są one niezrozumiałe. Zatem mimo że geowizualizacje wieloelementowe mogą cechować się ważnymi i unikalnymi zaletami, to użytkownicy nie będą świadomi, że opracowania tego typu mogą być pomocne w rozwiązywaniu różnych zadań. Obawy dotyczące postrzegania geowizualizacji wieloelementowych przez użytkowników jako zbyt złożone, nieintuicyjne, „zbyt naukowe” były już formułowane przez innych badaczy (Baldonado, Woodruff i Kuchinsky 2000; Opach i Rød 2013). N. Andrienko i współautorzy (2002) twierdzą, że dostępność i rozpowszechnienie narzędzia wynikają z łatwości, z jaką użytkownik może rozpocząć z nim pracę. Uważają jednocześnie, że wystarczy niewielki trening, wprowadzenie, aby użytkownicy z sukcesem zaczęli korzystać z geowizualizacji wieloelementowych (Andrienko i Andrienko 2001). Również inni autorzy sugerowali, że pewne wprowadzenie, trening lub instrukcja są niezbędne, by ułatwić użytkownikowi rozpoczęcie pracy z narzędziem tego typu (Edsall 2003; Robinson i współautorzy 2005; Opach i Rød 2014). Jednak aby opracować taką pomoc, należy określić, w jaki sposób początkujący użytkownicy swobodnie poznają nieznane narzędzie wieloelementowe, określić zatem jego nauczalność i sposób, w jaki użytkownicy uczą się jego działania i sposobów pracy z nim (Nielsen 1993).

\subsubsection{Formy materiałów szkoleniowych dla nowych użytkowników}

Materiały treningowe mogą różnić się stopniem rozbudowania (krótkie, lakoniczne wskazówki bądź rozbudowany materiał szkoleniowy), etapem pracy, na którym są one oferowane, sposobem umieszczenia w obrębie 
interfejsu, rodzajem wiedzy, do którego ten materiał się odnosi, oraz rodzajem użytego medium: tekst, wideo, nagrania głosowe (Mead 2014). Dotychczas proponowano różne formy tego typu materiałów szkoleniowych dla użytkowników geowizualizacji wieloelementowych. Rozwiązania te często znacząco różnią się między sobą.

Przykładowo, H. Kang, C. Plaisant, B. Shneiderman (2003a; 2003b) zaproponowali samouczek w postaci elementów wyglądających jak naklejane żółte kartki z przypomnieniami prezentującymi ważne informacje, w tym przypadku na temat funkcji wbudowanych w miejscu, na którym pojawia się owa „kartka”. Inną propozycją dla geowizualizacji wieloelementowych jest rozwiązanie omówione przez N. Andrienko i G. Andrienkę (2001), którego podstawą jest scenariusz pracy z narzędziem. Zaproponowane przez autorów rozwiązanie odnosi się do listy zadań możliwych do wykonania za pomocą podstawowych operacji. H. Kang, C. Plaisant, B. Shneiderman (2003a; 2003b) przedstawili rozwiązanie, w którym treści i funkcje wieloelementowego narzędzia geowizualizacji są prezentowane w coraz szerszym zakresie w kolejnych krokach. Na początku użytkownik korzysta z uproszczonego widoku, tak by mógł najpierw opanować podstawowe funkcje. Dopiero po ich zrozumieniu włączane są dodatkowe moduły oraz funkcjonalności, co pozwala uzyskać coraz bardziej złożone opracowanie. Podejście takie skutecznie zastosowali A. Slingsby i współautorzy (2014), nawiązując do idei projektowania gier dających satysfakcję (Ferrara 2012). Gracze są prowadzeni przez gry na coraz trudniejszych i bardziej złożonych poziomach. W ten sposób nie zniechęcają się, ale są uczeni coraz bardziej złożonych funkcji. Rozwiązanie to jednak niesie za sobą ryzyko, że użytkownik nie pozna wszystkich funkcjonalności narzędzia, a zatem nie dowie się do końca, w jaki sposób opracowanie może mu pomóc w rozwiązywaniu zadań. H. Kang, C. Plaisant, B. Shneiderman (2003b) zaproponowali również szkoleniowy film wideo, na którym omawiane są elementy interfejsu. Ta forma prezentacji jest pomocna, gdy potrzebne są komentarze słowne (ewentualnie w postaci napisów dla niesłyszących użytkowników) lub pokazanie sposobu pracy za pomocą ruchu kursora, kliknięcia myszy lub klawiszy na klawiaturze. Jednak jak zaznaczyli autorzy, takie rozwiązania są odpowiednie tylko dla krótkich materiałów szkoleniowych, które odnoszą się do konkretnych elementów narzędzi.

Mimo że wymienione powyżej przykłady dotyczą konkretnych rozwiązań projektowych, nie odnoszą się one do problemu bardziej ogólnego: co konkretnie powinno być tłumaczone w materiałach szkoleniowych geowizualizacji wieloelementowych oraz co jest kluczowe $w$ trakcie nauki tego typu opracowań. J. Nielsen (1993) określił nauczalność jako 
najbardziej podstawową cechę użyteczności. Dlatego badanie tego aspektu pracy z wieloelementowymi geowizualizacjami wydaje się być istotne.

Praca z geowizualizacjami wieloelementowymi, również na etapie ich uczenia się, wymaga interakcji, czyli „dialogu” między człowiekiem a narzędziem, który jest możliwy dzięki wykorzystaniu urządzenia komputerowego (Roth 2012). Niezbędnym tego elementem są funkcje interaktywne, które umożliwiają manipulację danymi oraz sposobami prezentacji tych danych i tym samym obejmują wiele rozwiązań. Możliwe, że użytkownicy, zwłaszcza uczący się narzędzia, mogą postrzegać pewne funkcje interaktywne jako mniej, a inne jako bardziej pomocne w trakcie uczenia się. Istotną wartość ma zatem określenie, które funkcje interaktywne są szczególnie przydatne dla użytkowników w trakcie uczenia się korzystania z geowizualizacji wieloelementowych.

Ponadto, mając na uwadze wielość i złożoność możliwych funkcji, jest ważne, by w trakcie projektowania i opracowania narzędzia, w tym także wyboru funkcji interaktywnych, podejmować świadome decyzje. Wachlarz dostępnych rozwiązań redakcyjnych dla geowizualizacji wieloelementowych jest szeroki, a sposób wyróżniania wybranych elementów stanowi jedno z nich (Robinson 2011). Jednak nie wszystkie rozwiązania cechują się podobną skutecznością i nie wszystkie są dostatecznie zbadane (Griffin i Robinson 2015). Istotną wartość może mieć zatem poznanie, do których elementów interfejsu użytkownicy odnoszą się, próbując zrozumieć sposób działania geowizualizacji wieloelementowych. Dlatego szczególne znaczenie może mieć zrozumienie, w jaki sposób niedoświadczeni użytkownicy, nieznający jeszcze wieloelementowego narzędzia geowizualizacji, poznają i spontanicznie się uczą pracy z nim. $\mathrm{Na}$ jakie elementy zwracają uwagę, a jakie z kolei są dla nich nieistotne przy pierwszym korzystaniu z niego.

Zakres problemów badawczych związanych z projektowaniem użytecznych geowizualizacji wieloelementowych jest więc rozległy. Częstym sposobem ich analizy są badania empiryczne, które niejednokrotnie umożliwiły rozwiązanie istotnych kwestii zarówno w zakresie kartografii, jak i geowizualizacji. 


\section{Badania użyteczności opracowań kartograficznych z wykorzystaniem okulografii}

Badania empiryczne z udziałem użytkowników, które czerpią z dorobku psychologii, od dawna znajdowały się w obszarze zainteresowań kartografii (zwłaszcza kartografii poznawczej) i geowizualizacji (Montello 2002; Żyszkowska 2015). Wyniki tych badań rozszerzały wiedzę kartografów na temat optymalizacji procesu opracowania, czytania i interpretacji map, a także umożliwiały zrozumienie, jak zaprojektować geowizualizacje odpowiednio do potrzeb grupy odbiorców i kontekstu, w którym dane opracowanie będzie wykorzystane (Slocum i współautorzy 2001; Kiefer i współautorzy 2017). W konsekwencji czerpano również z osiągnięć innych dyscyplin, takich jak kognitywistyka, nauki informatyczne, interakcja człowiek - komputer ( $\mathrm{HCl}$ : human-computer interaction), pedagogika, projektowanie graficzne, wizualizacja informacji czy statystyka (Griffin, Robinson i Roth 2017). Mapy, podobnie jak inne formy geowizualizacji, są medium przede wszystkim wizualnym, zatem poznawane są zmysłem wzroku. Nie dziwi więc fakt, że w trakcie poszukiwania sposobów badania czytania, analizy i interpretacji map uwaga kartografów została skierowana na metodę pomiaru ruchu gałki ocznej.

\subsection{Sposób odczytu obrazów wizualnych}

Oko jest podstawowym elementem systemu wzrokowego. O randze tego systemu dla poznania otoczenia świadczy fakt, że liczba receptorów w organizmie ludzkim rejestrujących obraz szacowana jest na 250 milionów. Jest to jednocześnie około:

- 10 razy więcej niż receptorów węchowych,

- 100 razy więcej niż receptorów dotykowych,

- 10000 razy więcej niż receptorów słuchowych. 


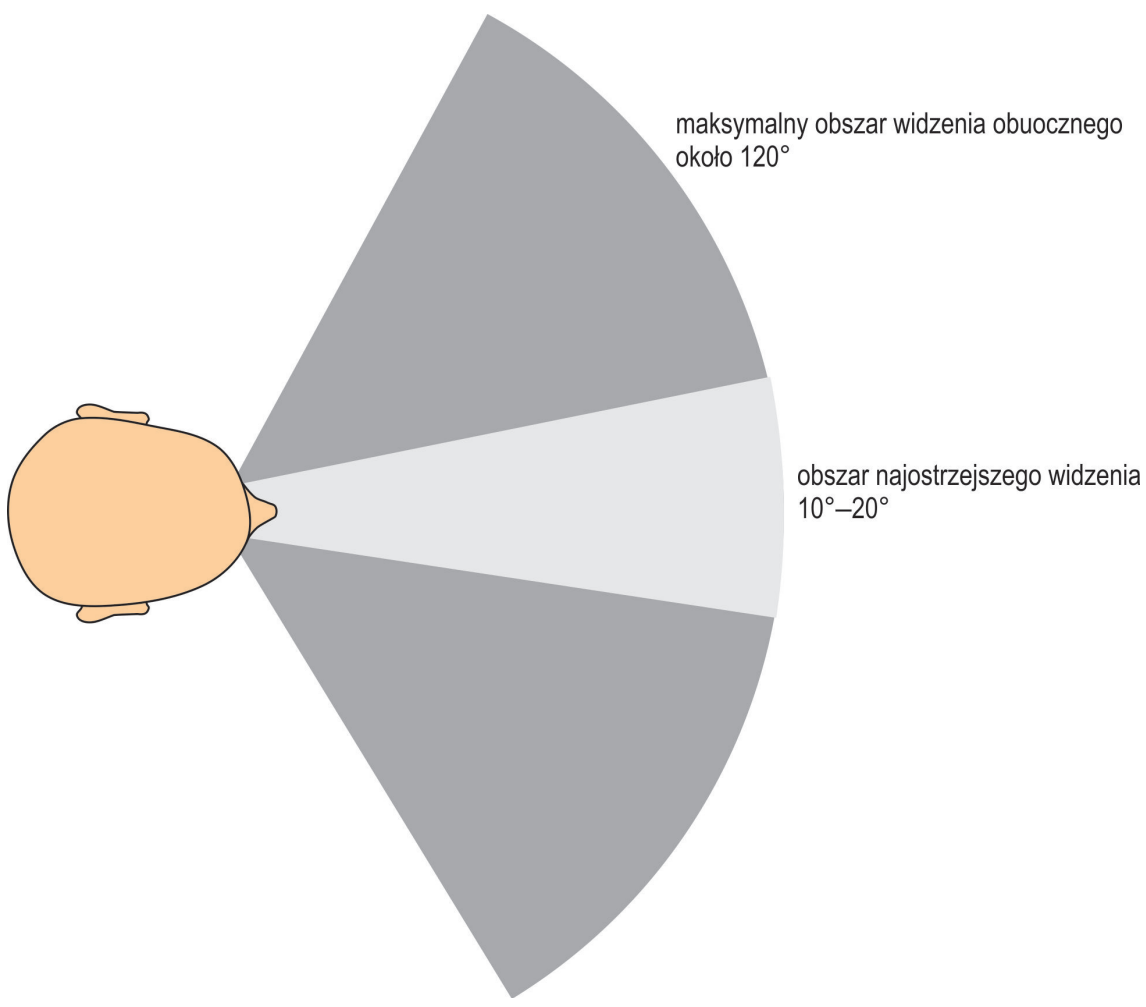

Rycina 3.1. Obszar widzenia obuocznego

Co ważne, rozmieszczenie fotoreceptorów na siatkówce oka jest nierównomierne, zatem wielkości obszarów, w których widzimy wyraźnie $\mathrm{i}$ jesteśmy w stanie rozpoznawać kolory oraz kształty, są różne. Obszar, w którym widzimy na tyle wyraźnie, by rozróżniać litery, jest bardzo wąski, obejmuje jedynie 1,5 stopnia pola widzenia. Odpowiada to w przybliżeniu szerokości jednego wyrazu w czytanym tekście (Soluch i Tarnowski 2013; Biecek 2016). Zatem aby odczytać tej wielkości elementy, człowiek powinien $w$ to miejsce skierować wzrok. Zakres widzenia obuocznego przedstawiono na ryc. 3.1.

Gałka oczna nieustannie wykonuje różnego rodzaju ruchy (Soluch i Tarnowski 2013). Wśród tych ruchów wyróżnia się fiksacje, podczas których wzrok skierowany jest na fragment obrazu przez określony odcinek czasu i odczytywane są widziane informacje. Pomimo że fiksacje są również ruchami, są interpretowane jako skupienia wzroku, gdyż te drobne ruchy służą poszerzeniu pola precyzyjnego widzenia (Soluch i Tarnowski 2013). Najczęściej przyjmowane minimum długości fiksacji 
to $200-400$ ms $(0,2-0,4$ sekundy). Jest to czas koncentracji wzroku, w trakcie którego odczytywana jest informacja. Fiksacje rozdzielone są krótkimi przeskokami nazywanymi sakkadami. Sakkada to szybki ruch oka pomiędzy fiksacjami, który trwa zazwyczaj 30-80 ms. W tym czasie nie jest odczytywana informacja. Zatem to, co zobaczymy i odczytamy, zależy od tego, na co skierowane będzie oko. Ruch gałek ocznych jest silnie związany z naszą uwagą i pytaniem, na które mózg stara się odpowiedzieć. Te ruchy można śledzić, rejestrować i analizować. Badania ruchu gałek ocznych (badania okulograficzne, zwane także angielskim terminem eye tracking ${ }^{1}$ ) przeprowadza się $\mathrm{w}$ odniesieniu do wielu zagadnień, m.in. w celu rozplanowania elementów na stronie internetowej lub produktów na półce sklepowej czy też na potrzeby badania analizy wzrokowej drogi w trakcie jazdy przez doświadczonych kierowców.

\subsection{Założenia metody eye tracking}

Spośród wielu metod zbierania danych empirycznych w trakcie pracy użytkowników z narzędziami geowizualizacji niewiele z nich umożliwia zbadanie zachowania w sposób nieinwazyjny i w zasadzie niezauważalny dla badanego. Jedną z takich metod jest eye tracking, która umożliwia śledzenie ruchu gałek ocznych i identyfikację miejsc, na które kieruje wzrok badana osoba (Duchowski 2007). Okulografia to zbiór metod i technik badawczych obejmujących pomiar, zapis i analizę danych o ruchach gałek ocznych $w$ danym przedziale czasowym. W metodzie tej dokonuje się pomiaru miejsca, na które skierowany jest wzrok (Points of Regards - POR). Miejsca te są określane za pomocą współrzędnych (np. współrzędnych ekranu). Pomiary są przeprowadzane z rozdzielczością zazwyczaj od 60 do około $500 \mathrm{~Hz}$ i więcej, co oznacza liczbę pomiarów miejsca spoglądania na sekundę, odpowiednio 60 do 500 pomiarów na sekundę (Kiefer i współautorzy 2017).

Od początku XX wieku rozwijane były różne technologie, włączając $w$ to inwazyjne urządzenia wymagające umieszczenia sensorów na gałce ocznej badanej osoby (ryc. 3.2). Najczęściej obecnie stosowana technika pomiaru ruchu gałki ocznej to foto- i wideookulografia. W ramach tej metody na oko lub oczy skierowane są kamera lub aparat, rejestrujące konkretne elementy gałki ocznej w trakcie ruchu (źrenicę, odbicie rogówkowe, rąbek rogówki itp.). Dla zwiększenia precyzji pomiaru używane

${ }^{1}$ Z racji popularności terminu angielskojęzycznego w języku polskim, zarówno w publikacjach naukowych, jak i w mediach, w dalszej części stosowany będzie ten termin zamiast polskiego tłumaczenia, które nie przyjęło się w szerokiej świadomości. 

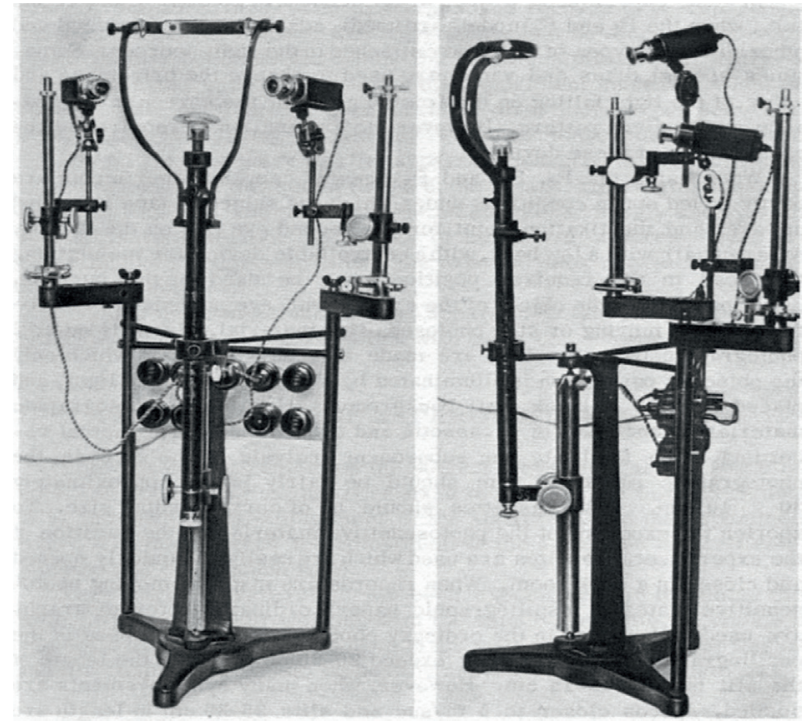

Rycina 3.2. Okulograf używany w połowie $X X$ wieku

Źródło: Wikipedia

jest również dodatkowe źródło światła oświetlające oko, aktualnie najczęściej jest to światło podczerwone (Soluch i Tarnowski 2013). Obecnie wykorzystywane są dwa rodzaje eye trackerów: stacjonarny i mobilny. Urządzenia stacjonarne mają zastosowanie w badaniach, w których testowane obrazy wyświetlane są na ekranie monitora (ryc. 3.3). Z kolei urządzenia mobilne stosowane są w badaniach, w których ważne jest zachowanie warunków jak najbardziej zbliżonych do naturalnych: badanie zachowania osób w sklepie i oglądania półek czy też poruszania się po mieście przez kierowców i innych uczestników ruchu (Dong i współautorzy 2020b). W związku z tym są to urządzenia często przypominające okulary, które osoba badana zakłada w trakcie badania. Mobilne urządzenia wymagają bardziej złożonej analizy danych z powodu zmieniającego się położenia badanego oraz kierunku patrzenia.

Metoda eye tracking w badaniach opracowań wizualnych jest chętnie wykorzystywana dzięki temu, że umożliwia analizę procesów poznawczych podczas patrzenia na te obrazy (Duchowski 2007; Ooms i współautorzy 2012a). Interpretacja wzajemnej relacji ruchów oka oraz procesów poznawczych jest często zdefiniowana przez założenia hipotezy "oko-umysł” (ang. mind-eye hypothesis) (Just i Carpenter 1980), która mówi, że człowiek poznaje i myśli o tym, na co patrzy. Według tej hipotezy kiedy badany patrzy na obiekt, w tym samym czasie (tak długo, jak długo 
A

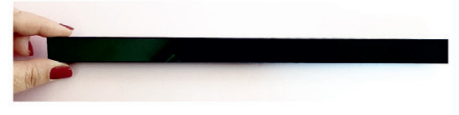

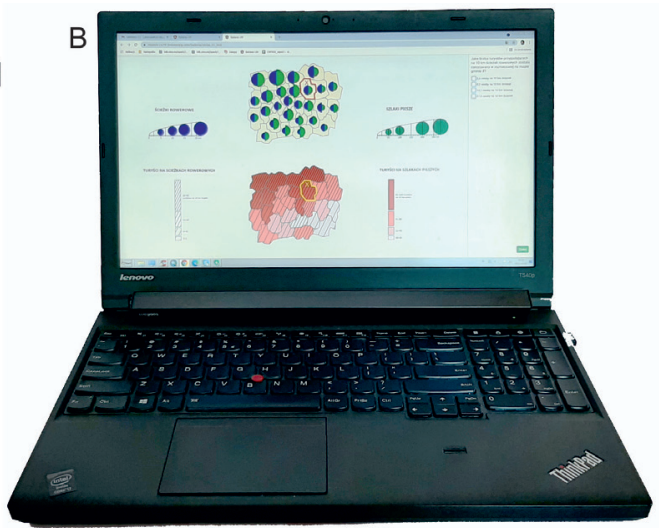

Rycina 3.3. Przykład eye trackera stacjonarnego do testowania obrazów wyświetlanych na ekranie monitora: obecnie stosowane urządzenia są niewielkich rozmiarów (A) i umieszczane są bezpośrednio przy monitorze, np. pod ekranem (B)

rejestrowana jest fiksacja) o nim myśli. Hipoteza ta była niejednokrotnie kwestionowana, nie została jednak odrzucona i nadal stosowana jest w założeniach badań z użyciem eye tracking. Na jej podstawie dokonywana jest interpretacja ruchów oka o różnej charakterystyce. Długie fiksacje wiązane są z intensywnym przetwarzaniem poznanej informacji (Holmqvist i współautorzy 2011). Jest zatem możliwe wskazanie, które elementy obrazu (np. mapy) zostały odczytane oraz poznane na podstawie ruchu oka i miejsc fiksacji wzroku.

Sposób czytania mapy jest z pewnością zależny od jej specyfiki i sposobu jej opracowania, ale również od strategii zachowania, działania, jaką przyjmuje jej użytkownik (Kiefer, Giannopoulos i Raubal 2013; Çöltekin i współautorzy 2019). Jak określają P. Kiefer i współautorzy (2017), uwaga wizualna (wzrokowa), czyli to, gdzie i na jak długo wzrok zostanie skierowany, jest sterowana zadaniem, jakie jest aktualnie rozwiązywane (van Zoest, Donk i Theeuwes 2004). Autorzy jednak zaznaczają, że sposób oglądania i analizy obrazów jest konsekwencją dwóch procesów: odgórnej uwagi oraz oddolnej reakcji na to, co widzimy. Wzrok jest bowiem kierowany na te miejsca, które przyciągają uwagę przez swój wygląd, duży kontrast, wyróżniające się elementy (Borji, Sihite i Itti 2013).

W przeszłości wykorzystanie metody eye tracking było ograniczone z powodu niedogodności pomiaru (w tym sprzętu pomiarowego, który powodował unieruchomienie badanego), a także trudności analizy 
bardzo dużej ilości pozyskanych danych. Rewolucja komputerowa, obok zupełnie nowych wyzwań badawczych dla kartografii i geowizualizacji, to również znaczne udogodnienia w zakresie pomiaru, zapisu i analizy danych eye tracking. Obecnie rejestracja przeprowadzana jest bezkontaktowo, a analiza danych dzięki użyciu odpowiedniego oprogramowania odbywa się w szybki, często zautomatyzowany sposób. Jest to jeden z ważnych powodów wzrostu popularności tej metody, ponieważ w trakcie badań eye tracking generowane są ogromne ilości danych. Sugestywne obliczenia przytoczone zostały przez T. Blascheck i współautorów (2017). Autorzy wyliczyli, że badanie z udziałem 30 uczestników, przy założeniu trzech zadań oraz 30 oglądanych obrazów, prowadzi do zapisu 2700 ścieżek skanowania wzrokiem. Każda taka ścieżka składa się z ogromnej liczby fiksacji i sakkad, a każda fiksacja składa się z serii zapisów miejsc patrzenia. Liczba tych zapisów zależy od częstotliwości pomiaru. Przy założeniu częstotliwości pomiaru 60 razy na sekundę (co obecnie nie jest raczej wysoką wartością), średniej długości fiksacji 250 ms oraz przyjęcia, że każdy obraz był oglądany tylko 2 minuty, może być wykonanych 20000000 pomiarów miejsc patrzenia i 1300000 fiksacji. Te ogromne ilości danych są zapisywane, a następnie poddawane odpowiednim obliczeniom i analizie. Bez skutecznego oprogramowania byłoby to niezmiernie trudne i czasochłonne, jeśli nie niemożliwe.

Zapisane pomiary są następnie przetwarzane: agregowane jako fiksacje i sakkady, które stanowią dwa podstawowe wskaźniki ruchu gałki ocznej. Istnieje wiele algorytmów wyliczania fiksacji (agregowania pomiaru), a programy do analizy danych eye tracking te obliczenia wykonują już samodzielnie. Popularne wskaźniki analizy danych, które wykorzystują fiksacje, to: liczba fiksacji, długość i położenie fiksacji, odległości między fiksacjami. Z kolei najczęściej stosowane wskaźniki sakkad to: długość, czas trwania sakkad oraz ich prędkość. Ścieżka skanowania to ciąg fiksacji i sakkad występujących po sobie (ryc. 3.4). Opisuje ona obszar, jaki osoba przeanalizowała wzrokiem.

Często w trakcie analizy danych wyróżniane są obszary zainteresowania (Areas of Interests: AOI). To obszary na prezentowanym obrazie ważne z punktu widzenia celu badania. Są wyróżniane w celu sprawdzenia, z jaką intensywnością, w jakiej kolejności, w jakim zakresie i w jaki sposób były one studiowane przez badanego. Obszary te można wyróżniać przed badaniem lub po nim. Zazwyczaj AOI oznacza miejsce, w którym znajdują się informacje potencjalnie ważne dla badanego. Wskaźnikami odnoszącymi się do AOI są najczęściej przejścia pomiędzy obszarami zainteresowań oraz długość fiksacji w obrębie danego AOI. 


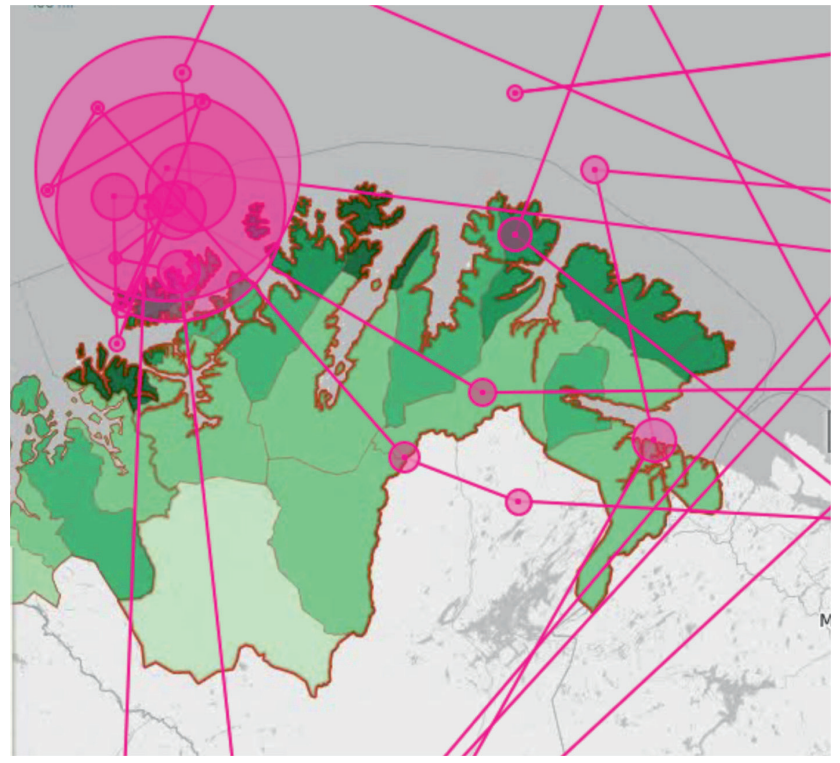

Rycina 3.4. Wizualizacja fiksacji i sakkad w trakcie oglądania mapy opracowanej metodą kartogramu: okręgi pokazują fiksacje (im dłuższy promień koła, tym dłuższy czas koncentrowania wzroku w danym miejscu), linie pomiędzy fiksacjami prezentują sakkady

Poza analizą danych eye tracking na podstawie wspomnianych wyżej wskaźników, jak liczba i długość fiksacji oraz położenie fiksacji, pomocne $w$ analizowaniu danych eye tracking są również wizualizacje zebranych danych. T. Blascheck i współautorzy (2017) wyróżnili szereg możliwych form wizualizacji. Wizualizacje niewymagające określania obszarów zainteresowań (ryc. 3.5 A-F) mają różne formy. Są to metody prezentujące dane dotyczące podstawowych wskaźników, np. długości trwania fiksacji przez różne grupy użytkowników w postaci wykresów słupkowych (ryc. 3.5 A), liniowych, punktowych, pudełkowych i gwiaździstych. Wartości te mogą być również odniesione do regularnej siatki badanego obrazu lub interfejsu (ryc. 3.5 B). Wizualizacje mogą również uwzględniać zmiany w czasie (ryc. 3.5 C-F): wizualizacja ścieżki patrzenia (ryc. $3.5 \mathrm{C}$ ) pokazująca kolejne fiksacje (koła) i sakkady (linie), mapy cieplne (ang. heatmap) prezentujące długość fiksacji w różnych miejscach (ryc. 3.5 D) i mapy uwagi prezentujące, które obszary zostały odczytane (jest to niejako odwrotność mapy cieplnej) (ryc. 3.5 E), oraz sześcian czasowo-przestrzenny (ang. space-time cube) prezentujący na osi Y czas (ryc. 3.5 F). Z kolei prezentacje, dla których niezbędne jest określenie AOI (ryc. $3.5 \mathrm{G}-\mathrm{I}$ ), to: prezentacja zmiany uwagi na 

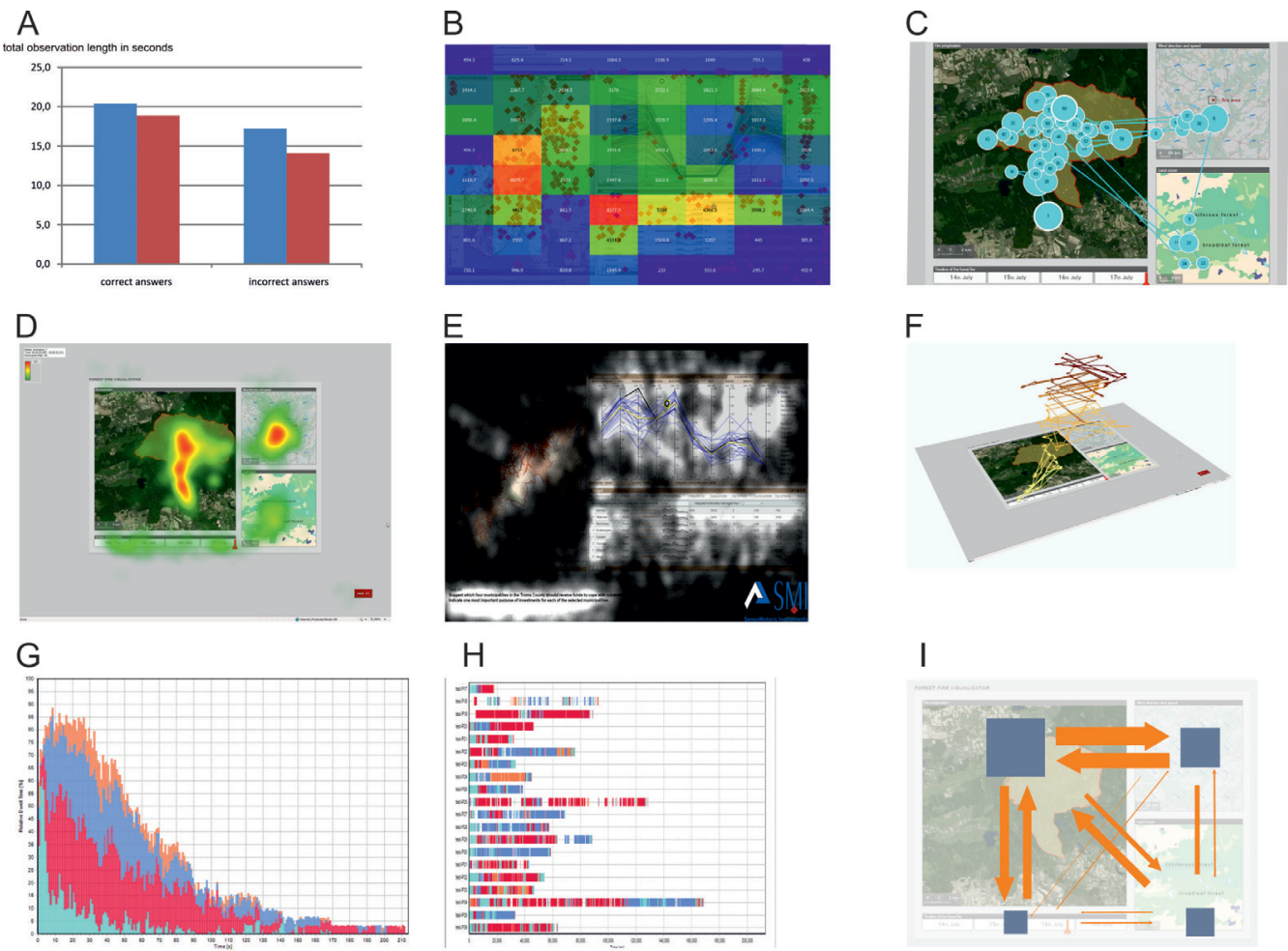

Rycina 3.5. Różne sposoby wizualizacji danych eye tracking

AOI w czasie rozwiązywania zadania przez wszystkich uczestników badania (ryc. $3.5 \mathrm{G}$ ) oraz prezentacja tych danych dla poszczególnych osób badanych (ryc. $3.5 \mathrm{H}$ ), prezentacje 3D (stosowane w badaniach przy użyciu mobilnych eye trackerów i zawierające zdjęcia np. półek sklepowych), prezentacje liczby przejść między obszarami zainteresowań (ryc. $3.5 \mathrm{H}$ ).

Eye tracking jest zatem źródłem niezwykle bogatych danych na temat tego, gdzie, kiedy, jak długo i w jakiej kolejności użytkownik odczytuje obraz, w tym mapy i inne geowizualizacje. Możliwości analizy i wizualizacji tych danych są obecnie bardzo szerokie, a jednocześnie ułatwione przez dostępne oprogramowanie, zarówno producentów eye trackerów (np. Tobii), jak i programów rozwijanych niezależnie, jak na przykład OGAMA (Voßkühler i współautorzy 2008), EyeMMV (Krassanakis, Filippakopouloui i Nakos 2014) lub ScanGraph (Dolezalova i Popelka 2016).

Takie bogactwo danych, które daje szerokie możliwości analizy oraz wyciągania wniosków i obserwacji na temat badanych procesów, jest 
jednym z powodów, że liczba uczestników badań z zastosowaniem metody eye tracking może być nieduża, podobnie jak w innych metodach stosowanych głównie w badaniach o charakterze jakościowym. Zalecenia dotyczące liczby uczestników w badaniach eye tracking sformułowane przez K. Pernice'a i J. Nielsena (2009) wskazują, że tylko $\mathrm{w}$ badaniach, w których mapy cieplne (heat map) są podstawowym źródłem analiz i formułowania wniosków - grupa powinna liczyć 39 badanych, jednak w badaniach, w których dane analizowane są w inny sposób, również za pomocą odtwarzania procesu oglądania testowanego materiału, już nawet sześcioosobowe grupy badanych pozwalają na sformułowanie wartościowych wniosków. Zalecenia te dotyczą również badań z wykorzystaniem metody eye tracking dotyczących użyteczności narzędzi geowizualizacji. Jak wykazało zestawienie przygotowane przez T. Opacha (2011), liczba osób biorących udział w badaniach z wykorzystaniem metody eye tracking z zakresu kartografii oraz nauki o informacji przestrzennej opublikowanych po 2000 roku przez czołowych badaczy w tych dyscyplinach wahała się od 8 do 34, rzadko przekraczając 20 osób. Wszystkie te badania pozwoliły na sformułowanie wartościowych wniosków, w tym testowanie hipotez (np. Fabrikant i współautorzy 2008; Çöltekin i współautorzy 2009), zarówno w odniesieniu do sposobu projektowania map statycznych, jak i interaktywnych geowizualizacji. Podobnie wiele badań z zakresu kartografii wykorzystujących inne metody dostarcza wartościowych wyników, bazując na danych zebranych od stosunkowo niewielkiej liczby osób, nie większej niż 30 (Medyńska-Gulij 2007b) czy około 40. Przykładowo, B. Konopska (2012) wykazała przydatność jakościowej metody zogniskowanego wywiadu grupowego z użytkownikami map na temat publikacji kartograficznych. Badania takie prowadzi się z udziałem 8-12 osób i - jak wykazała autorka - dają one możliwość uzyskania wiarygodnych wyników na temat zachowań odbiorców czy ich ocen dotyczących opracowań kartograficznych. Zatem również badania, które nie angażują dużej liczby uczestników, przy wykorzystaniu odpowiednich metod dają możliwość uzyskania wartościowych wniosków.

\subsection{Zastosowanie metody eye tracking w kartografii i geowizualizacji}

Eye tracking to metoda badawcza, która znalazła zastosowanie w wielu dyscyplinach naukowych oraz na różnych polach działalności praktycznej, 
takich jak: psychologia, pedagogika, marketing czy badania użyteczności (ang. usability). W kartografii pierwsze przykłady zastosowań miały miejsce w latach 70. i 80. XX wieku (Jenks 1973; Dobson 1977; Castner i Eastman 1984; 1985; Chang, Antes i Lenzen 1985; Steinke 1987). Metoda okulografii stała się już integralną częścią badań i praktyki naukowej w kartografii i geowizualizacji (Kiefer i współautorzy 2017). Zakres zastosowania eye tracking $w$ tych dyscyplinach jest szeroki i był już kilkukrotnie podsumowywany w postaci przeglądowych zestawień, w których autorzy dokonywali analizy szeregu publikacji wykorzystujących tę metodę (np. Opach 2011; Andrienko i współautorzy 2012; Blascheck i współautorzy 2017; Kiefer i współautorzy 2017; Krassanakis i Cybulski 2019).

Badania w kartografii i geowizualizacji z zastosowaniem eye tracking obejmują zarówno mapy statyczne (Fabrikant, Hespanha i Hegarty 2010; Ooms i współautorzy 2012b), animowane (Opach, Gołębiowska i Fabrikant 2014), jak i interaktywne (Çöltekin i współautorzy 2009). W badaniach weryfikowany jest na przykład wpływ różnic między grupami odbiorców na sposób pracy z mapą. Przykładem są badania dotyczące wpływu doświadczenia i wiedzy na sposób użytkowania mapy przez kartografów i osoby niezwiązane profesjonalnie z kartografią (Ooms i współautorzy 2012a; Havelková i Gołębiowska 2019). Poprzez porównanie alternatywnych rozwiązań poszukiwana jest również odpowiedź na pytanie, jak projektować efektywne mapy i geowizualizacje (Çöltekin i współautorzy 2009).

Analiza 76 artykułów naukowych opublikowanych w latach 20092018 przeprowadzona przez V. Krassanakisa i P. Cybulskiego (2019) pozwoliła wyróżnić zagadnienia podejmowane w badaniach $w$ drugiej dekadzie XXI wieku. Dotyczą one dość szerokiego zakresu zagadnień: sposobów redakcji map i empirycznej weryfikacji zasad ich opracowania, porównania prezentacji dwu- i trójwymiarowej, badań dotyczących wpływu wiedzy i doświadczenia na sposób użytkowania map oraz innych. Autorzy wymienili również szereg narzędzi i metod analizy danych eye tracking zaproponowanych przez środowisko kartograficzne, które mogą znaleźć zastosowanie również w innych dyscyplinach wykorzystujących tę metodę zbierania danych.

Metoda okulografii nadal wydaje się oferować niewykorzystane jeszcze w pełni możliwości (Montello 2009). Dowodem na to jest fakt, że metoda ta znajduje zastosowanie również w nowych kontekstach, jak np. rzeczywistość rozszerzona (Dong i współautorzy 2020a). Ponadto okazuje się być wyśmienitym uzupełnieniem metod badawczych, które 
dopiero znajdują zastosowanie $w$ dyscyplinie geowizualizacji, jak elektroencefalografia² (EEG) (Keskin i współautorzy 2019; 2020).

O ile metoda eye tracking od dziesięcioleci znajduje zastosowanie w badaniach empirycznych map statycznych, o tyle w zakresie oceny i badania narzędzi geowizualizacji, a zwłaszcza wieloelementowych geowizualizacji, zastosowanie tej metody zbierania danych jest nadal obszarem o niewykorzystanym w pełni potencjale.

2 Elektroencefalografia (EEG) to nieinwazyjna metoda diagnostyczna służąca do badania bioelektrycznej czynności mózgu. Badanie polega na odpowiednim rozmieszczeniu na powierzchni skóry czaszki elektrod, które rejestrują zmiany potencjału lub różnice w potencjale różnych części mózgu (Majkowski 1989). 


\section{Empiryczna weryfikacja rozważań teoretyczno-koncepcyjnych}

Przedstawione powyżej zagadnienia mogą stanowić podstawę do wskazania problemów i sformułowania pytań badawczych, które można zweryfikować empirycznie ${ }^{1}$. Problem optymalizacji wieloelementowych geowizualizacji może być rozwijany - podobnie jak w analogicznych badaniach innego typu opracowań - poprzez poznanie sposobu pracy użytkowników z nimi, zwłaszcza użytkowników początkujących. Pozwoli to na określenie zaleceń dotyczących redakcji legendy - elementu niezwykle ważnego z punktu widzenia zarówno semantyki, jak i pragmatyki kartograficznej. Taka wiedza umożliwi również sformułowanie wskazówek do przygotowania materiałów wprowadzających dla początkujących użytkowników. Ponadto, jak wykazano w rozdziale 2.4 , redundancja była przedmiotem analiz w odniesieniu do map pojedynczych, nie była natomiast przedmiotem analiz odnośnie do geowizualizacji wieloelementowych. Nie prowadzono dotychczas badań sposobu i zakresu, w jakim użytkownicy korzystają z wieloelementowego narzędzia geowizualizacji cechującego się redundancją danych pomiędzy modułami.

Postawiono w związku z tym ogólne pytanie badawcze o charakterze eksploracyjnym:

1. Jak użytkownicy zapoznają się z nieznanym wieloelementowym narzędziem geowizualizacji w czasie swobodnej pracy?

$\mathrm{Na}$ jego podstawie sformułowano szczegółowe pytania badawcze o następującym brzmieniu:

1a. Które funkcje oraz elementy interfejsu są pomocne w nauce nieznanego wieloelementowego narzędzia geowizualizacji?

${ }_{1}$ Związek między prezentowanymi badaniami empirycznymi a wcześniejszymi publikacjami Gołębiowska, Opach i Rød $(2017,2020)$ został wyjaśniony na stronach 12-13. 
1b. Na których elementach interfejsu geowizualizacji wieloelementowej użytkownicy koncentrują się $w$ trakcie poznawania nieznanego wcześniej narzędzia?

1c. Które funkcje interaktywne są przez użytkowników chętnie wykorzystywane w celu zrozumienia, jak działa wieloelementowe narzędzie geowizualizacji?

Drugie pytanie badawcze ma na celu weryfikację przydatności redundancji w wieloelementowym narzędziu geowizualizacji:

2. Czy użytkownicy wieloelementowego narzędzia geowizualizacji w trakcie rozwiązywania pojedynczego zadania przenoszą swoją uwagę pomiędzy modułami prezentującymi te same dane w różny sposób?

Interesuje mnie zatem, czy w trakcie rozwiązywania pojedynczego zadania użytkownicy unikają zmiany kontekstu pomiędzy modułami i czy chcąc ograniczyć swoje obciążenie poznawcze - będą koncentrować swoją uwagę tylko na jednym elemencie, czyli unikać przenoszenia uwagi na pozostałe elementy, zwłaszcza te, które są mniej znane oraz uważane za trudne i nieprzystępne. Jak wskazują wyniki wcześniejszych badań, w których wykorzystano mniej rozbudowane - dwuelementowe opracowania, można sądzić, że mogą być wykorzystane efektywnie również narzędzia składające się z trzech modułów, nawet jeśli mają one mało popularną formę prezentacji danych. Geowizualizacje wieloelementowe, cechujące się redundancją danych prezentowanych w różnych modułach, są z reguły wykorzystywane przez użytkowników. Sformułowana więc została następująca hipoteza będąca próbą odpowiedzi na drugie pytanie badawcze:

H1. Użytkownicy wieloelementowego narzędzia geowizualizacji w trakcie rozwiązywania pojedynczego zadania przenoszą swoją uwage pomiędzy modułami prezentującymi te same dane $w$ różny sposób.

Jak wykazały wcześniejsze postulaty i badania (np. Edsall 2003; Koua, MacEachren i Kraak 2006; Saket, Endert i Demiralp 2019), różnego rodzaju operacje predestynują inne formy prezentacji do ich realizacji. Nie było to jednak weryfikowane w kontekście wieloelementowych geowizualizacji prezentujących te same dane w różnych modułach. Zatem postawiono następujące pytanie badawcze: 


\section{Czy wykorzystanie modułów do odczytania informacji różni się pomiędzy rodzajami rozwiązywanych zadań?}

Ważny potencjał wieloelementowych geowizualizacji to możliwość elastycznego wykorzystania modułów w zależności od rodzaju poszukiwanej informacji i charakterystyk prezentowanych danych, ale także preferencji i przyzwyczajeń ich użytkowników. Dlatego sformułowana została druga hipoteza, będą próbą odpowiedzi na trzecie pytanie badawcze:

\section{H2. W zależności od rodzaju zadania użytkownicy odczytują infor- macje z różnych modułów wieloelementowej geowizualizacji prezentujących te same dane.}

Zatem hipoteza pierwsza $\mathrm{H} 1$ dotyczy różnic w wykorzystaniu modułów $w$ trakcie rozwiązywania pojedynczego zadania, natomiast hipoteza druga H2 odnosi się do różnic w sposobie korzystania z modułów narzędzia pomiędzy różnymi zadaniami.

Aby odpowiedzieć na powyższe trzy pytania badawcze oraz zweryfikować dwie sformułowane hipotezy, przeprowadzono badania empiryczne. Celem badań empirycznych było zatem rozpatrywanie geowizualizacji wieloelementowej po osadzeniu na gruncie semiotyki kartograficznej. W szczególności należy podkreślić semantyczny aspekt badań, w którym kwestia doboru danych prezentowanych w poszczególnych modułach, skutkująca redundancją danych pomiędzy modułami, była jednym z ważnych zagadnień. Zwrócono również uwagę na legendę, jako na szczególnie istotny element z punktu widzenia semantyki. Badania były przeprowadzane z pragmatycznego punktu widzenia, a ich celem była analiza sposobu uczenia się narzędzia oraz sposobu jego postrzegania przez samych użytkowników. W efekcie weryfikacja postawionych hipotez oraz odpowiedź na pytania badawcze (w tym pytania o charakterze eksploracyjnym) pozwolą na poszerzenie wiedzy na temat sposobu pracy użytkowników z danymi przestrzennymi przy wsparciu interaktywnych, wieloelementowych geowizualizacji.

W badaniach przyjęto następujące zmienne: forma prezentacji danych w module narzędzia, rodzaj zadania jako zmienne niezależne, a poprawność odpowiedzi oraz uwaga wizualna (określona przez wskaźniki eye tracking) - jako zmienne zależne. Zastosowano wewnątrzgrupowy schemat badawczy. 


\subsection{Testowane wieloelementowe narzędzie geowizualizacji}

Do badania wykorzystano opracowanie składające się z trzech elementów, zwanych dalej modułami. Każdy z trzech modułów prezentuje te same dane. W badaniu wykorzystano narzędzie nazwane ViewExposed, opracowane w Zakładzie Geografii na Wydziale Nauk Społecznych i Pedagogicznych Norweskiego Uniwersytetu Nauki i Technologii w Trondheim w ramach projektu NORD-STAR (the Top-level Research Initiative/NordForsk through the contribution to the Nordic Center of Excellence for Strategic Adaptation Research) (Opach i Rød 2013). Narzędzie to zostało opracowane dla decydentów pochodzących z jednostek samorządu terytorialnego w Norwegii, zatem dla osób charakteryzujących się odpowiednim poziomem wiedzy i zakresem umiejętności. Trzy moduły narzędzia prezentują dane za pomocą różnych form: mapy tematycznej, wykresu osi równoległych oraz tabeli (ryc. 4.1).

Prezentowane dane dotyczą podatności na zagrożenia naturalne w gminach w Norwegii. Zintegrowany wskaźnik podatności na zagrożenia naturalne łączy wskaźniki ekspozycji na ekstremalne zjawiska: powodzie, osuwiska i burze, razem ze wskaźnikami podatności społecznej (Rød, Opach i Neset 2015). Uwzględnia zatem fakt, że podatność na zagrożenia jest wypadkową uwarunkowań fizycznogeograficznych oraz czynników społeczno-gospodarczych. Wysokie wartości wskaźników ekspozycji oznaczają, że w danej gminie znajduje się duża liczba budynków usytuowanych w potencjalnie niebezpiecznych miejscach. Z kolei wskaźniki podatności społeczno-gospodarczej informują o możliwości jednostek samorządu do przygotowania się oraz odbudowania szkód po wystąpieniu zjawisk ekstremalnych. Pokazanie tych danych za pomocą rozmaitych form prezentacji pozwala użytkownikom eksplorować dane w różny sposób: mapa (kartogram) umożliwia identyfikację obszarów najbardziej podatnych (odpowiada na pytanie: gdzie?), wykres osi równoległych, prezentujący jednocześnie kilka wskaźników budujących zintegrowany wskaźnik podatności, pozwala na określenie, jakie czynniki powodują, że dany obszar jest podatny na zagrożenia (odpowiada na pytanie: dlaczego?), z kolei tabela umożliwia wgląd do danych szczegółowych.

Moduły narzędzia są interaktywnie połączone ze sobą. Oznacza to, że przy zaznaczeniu jednego obiektu w jednym module odpowiadające mu obiekty zaznaczają się w pozostałych modułach: na mapie zostaje wyróżniony zaznaczony obszar, w obrębie wykresu osi równoległych linia reprezentująca tę gminę jest wyróżniona kolorem, a wiersz $w$ tabeli odpowiadający tej jednostce podziału administracyjnego jest również 


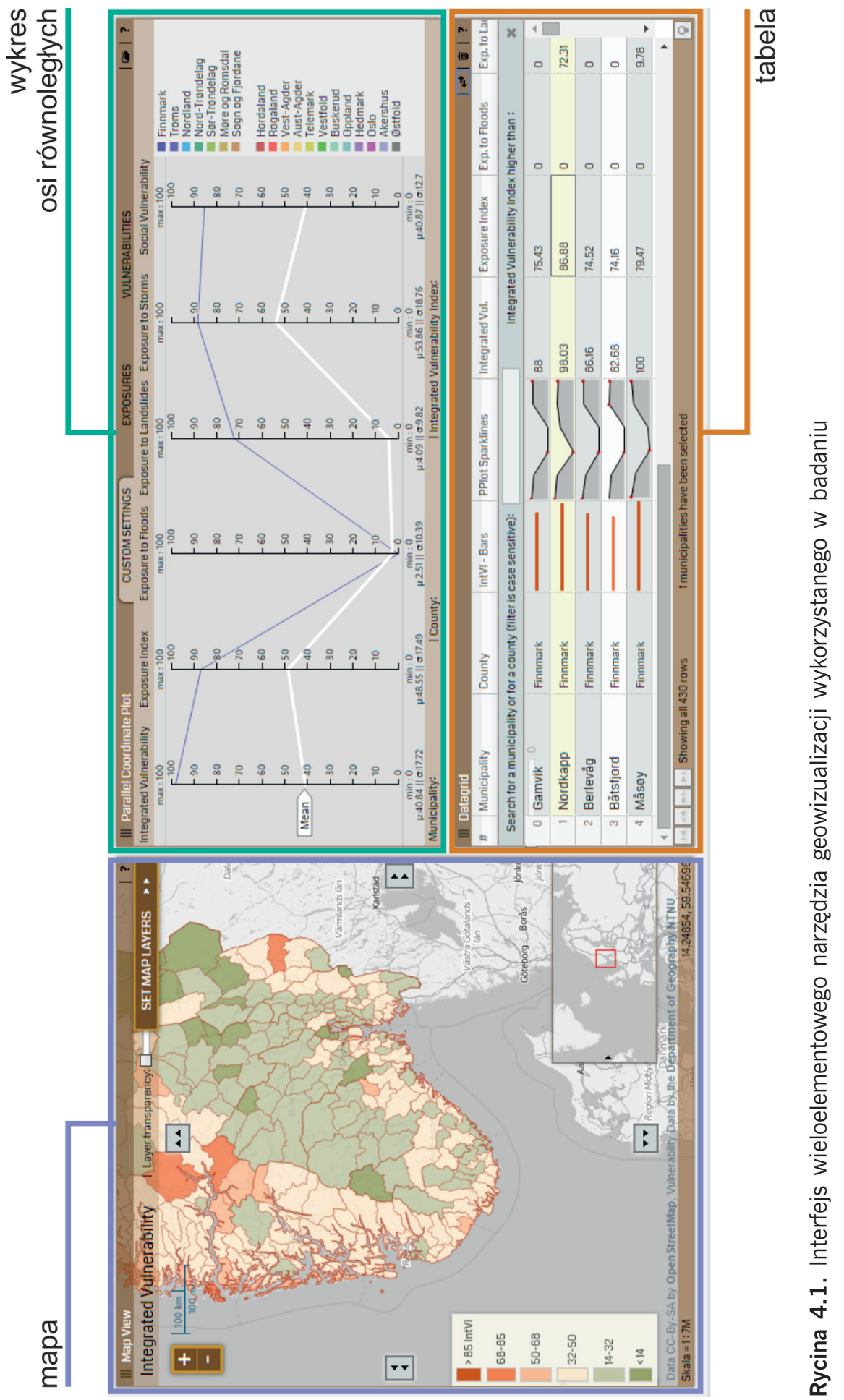



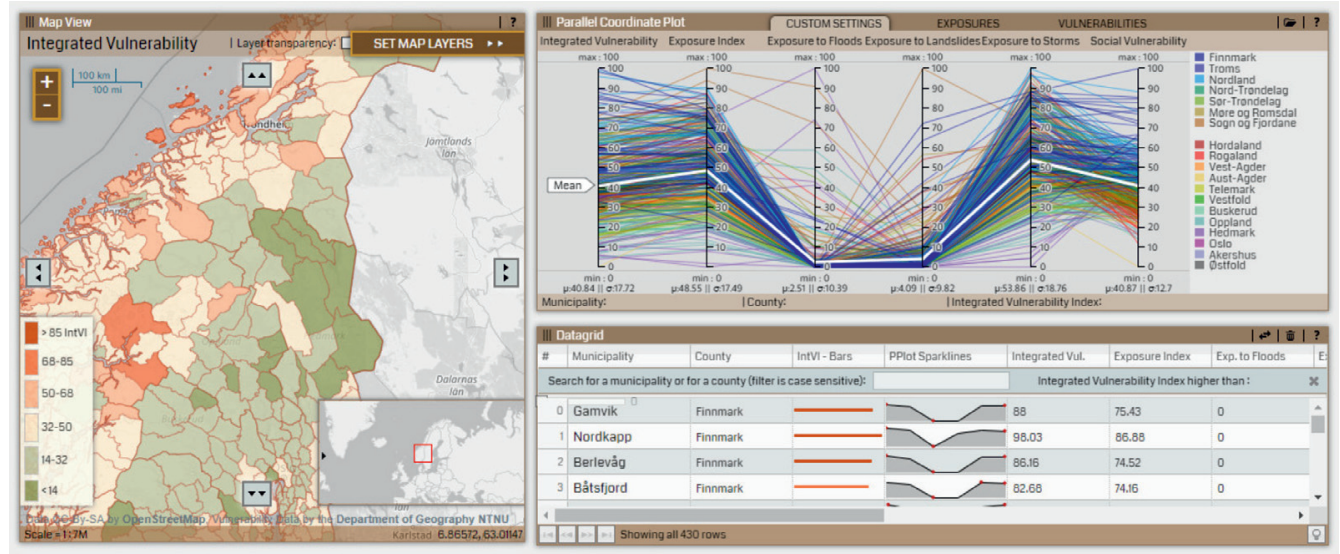

Rycina 4.2. Wygląd testowanego narzędzia po jego otwarciu
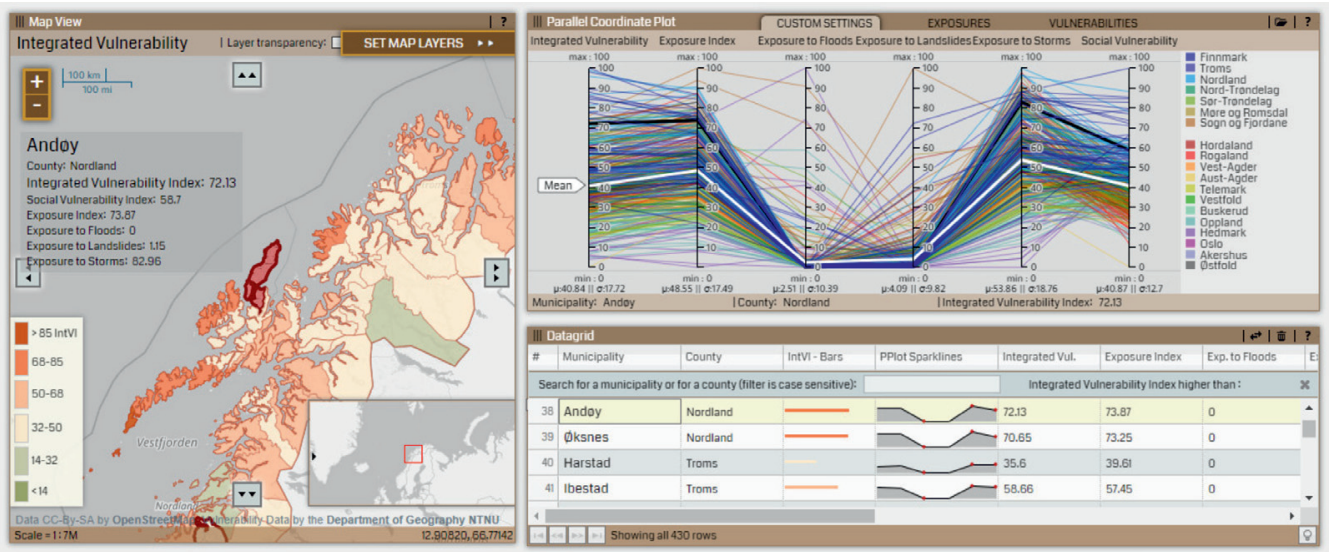

Rycina 4.3. Wygląd narzędzia po zaznaczeniu linii na wykresie osi równoległych

wyróżniony innym tłem od pozostałych wierszy. Narzędzie po uruchomieniu pokazuje wszystkie elementy bez wyróżnienia (ryc. 4.2).

Po zaznaczeniu linii na wykresie osi równoległych (ryc. 4.3) zostaje ona wyróżniona kolorem czarnym. Mapa zmienia swój zasięg, tak by na środku prezentowanego terenu znajdował się obszar odpowiadający wybranej linii. Sama jednostka administracyjna na mapie zostaje również wyróżniona grubszym konturem. W tabeli z kolei wiersz odpowiadający wybranej linii zostaje pokazany jako pierwszy oraz jest wyróżniony jasnożółtym tłem. 


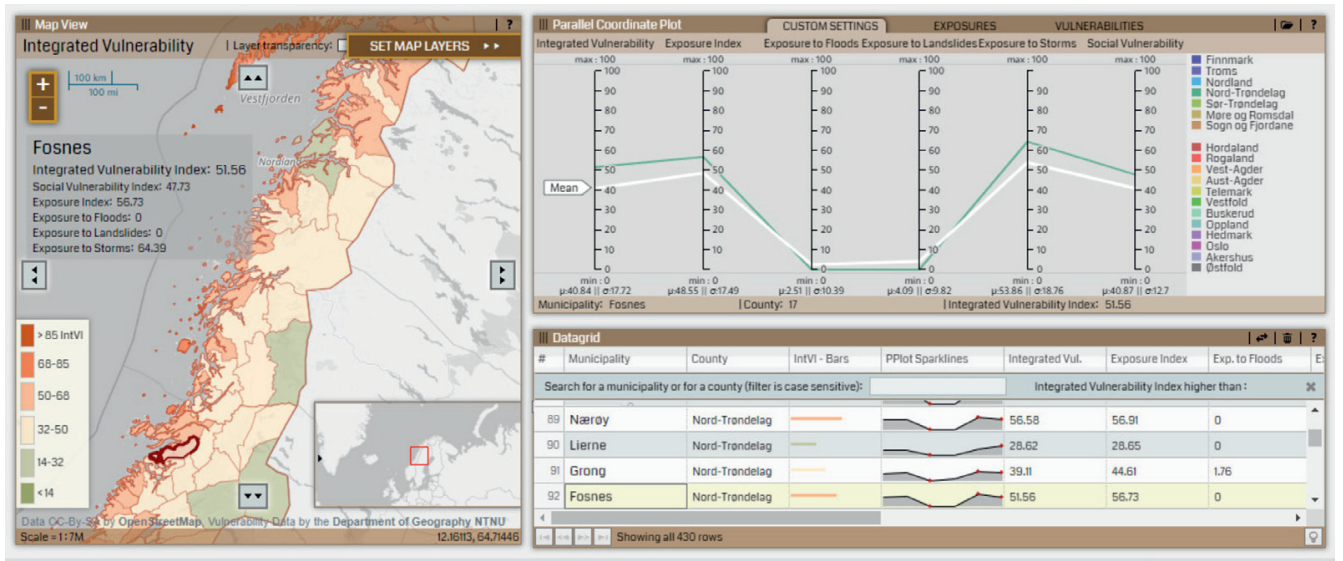

Rycina 4.4. Sposób wyróżnienia odpowiednich elementów po wybraniu obszaru na mapie

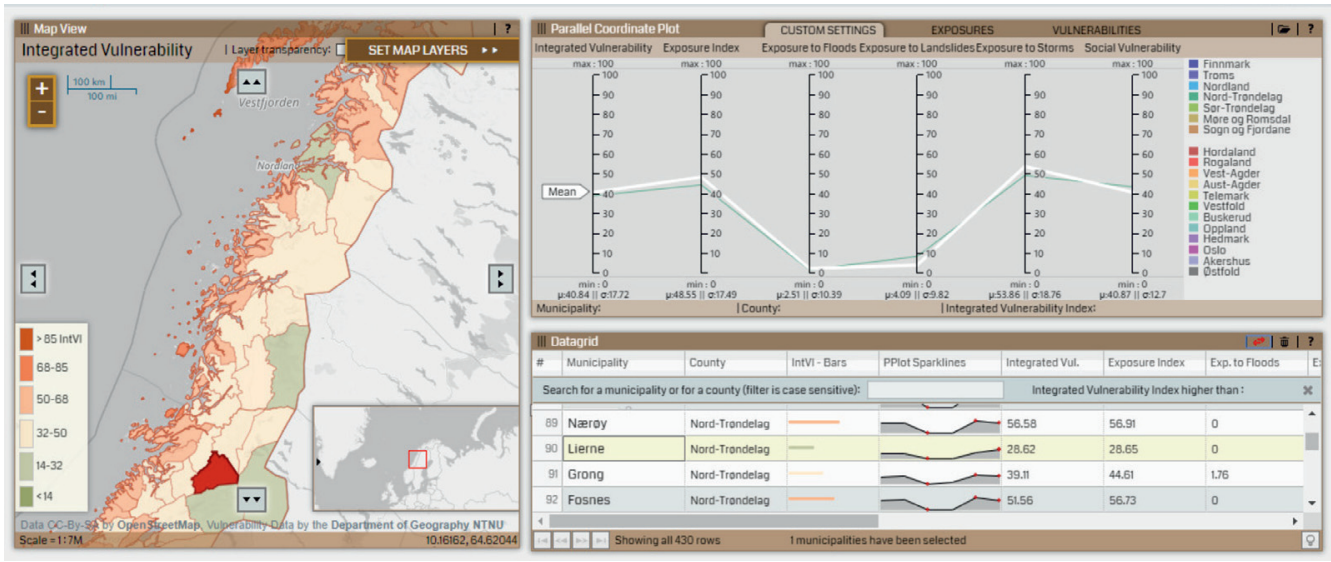

Rycina 4.5. Oznaczenie odpowiadających obiektów po wybraniu wiersza w tabeli

Zaznaczenie gminy na mapie (ryc. 4.4) skutkuje wyróżnieniem grubszym konturem jej obszaru oraz filtrowaniem treści wykresu: na wykresie pokazana jest linia odpowiadająca wybranemu na mapie obszarowi oraz linia prezentująca wartości średnie dla całej Norwegii. Pozostałe linie odnoszące się do poszczególnych obszarów podziału administracyjnego są niewidoczne. W tabeli odpowiedni wiersz zostaje wyróżniony innym tłem.

Zaznaczenie wiersza w tabeli (ryc. 4.5) powoduje wyróżnienie go innym kolorem tła, na wykresie zaś - podobnie jak w poprzednim 
A

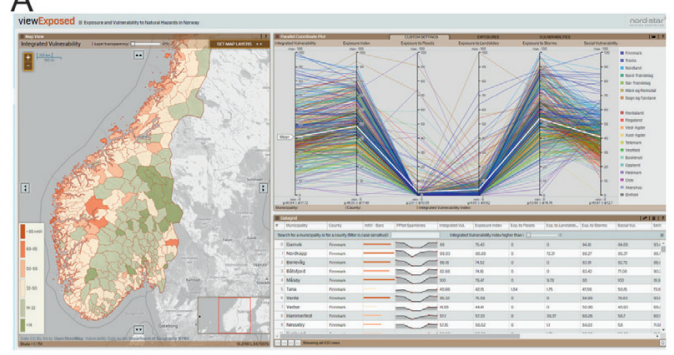

C

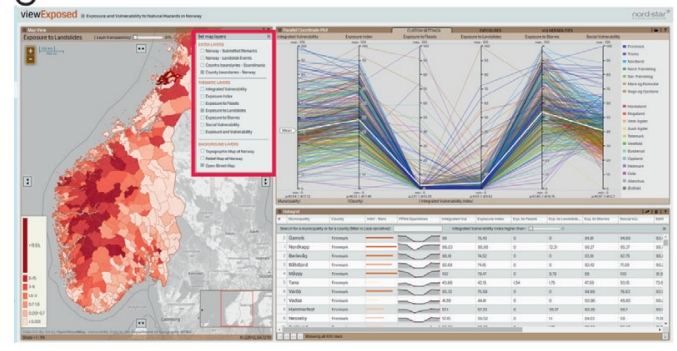

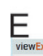

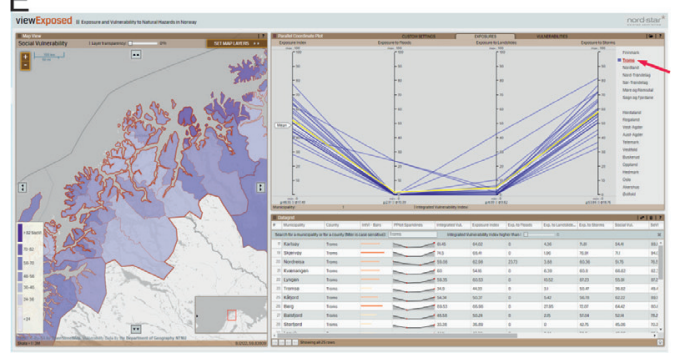

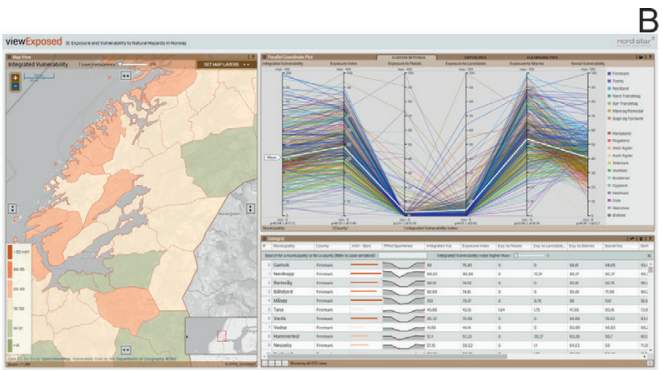

D
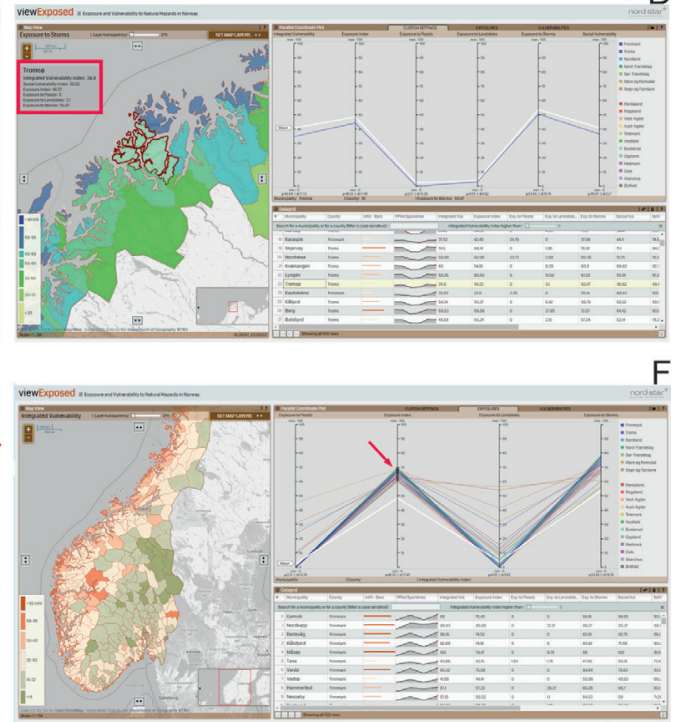

Rycina 4.6. Wybrane funkcje interaktywne testowanego narzędzia (szczegółowy opis w tekście)

przypadku - jest przedstawiana tylko linia symbolizująca jednostkę reprezentowaną przez zaznaczony wiersz oraz linia pokazująca wartości średnie dla całego państwa. Na mapie odpowiednia gmina zostaje wyróżniona innym kolorem niż pozostałe jednostki.

Ponadto w narzędziu zastosowano dwa rodzaje wyróżniania obiektów (Andrienko i współautorzy 2002). Obiekty są wyróżniane, gdy użytkownik najeżdża kursorem myszy na dany obiekt (np. linię na wykresie), umożliwiając identyfikację obiektu. Oznaczenie to znika, gdy tylko użytkownik odsunie kursor myszy od tego obiektu. Drugi powszechnie stosowany rodzaj zaznaczania obiektów realizowany jest poprzez naciśnięcie lewego klawisza myszy: obszaru na mapie, linii na wykresie czy wiersza w tabeli. Również w poszczególnych modułach wykorzystano różne funkcje interaktywne (ryc. 4.6). Testowane narzędzie umożliwia modyfikację 
mapy: zmianę jej skali (poprzez użycie klawiszy + i - oraz za pomocą myszy), a także zasięgu mapy (również za pomocą klawiszy lub myszy) (ryc. 4.6 A, B pokazują narzędzie z mapą w różnej skali i zmienionym zasięgiem prezentowanego obszaru). Ponadto tematyka mapy może zostać zmieniona: naciskając przycisk „Set map layers”, użytkownik wybiera $z$ listy, jakie dane chce prezentować kartogramem w module mapy (4.6 C, czerwony prostokąt wskazuje listę wyboru map o różnej tematyce). Po wybraniu określonej jednostki na mapie pojawia się panel informacyjny z wartościami wskaźnika na jej obszarze (4.6 D, czerwony prostokąt wskazuje panel dla wybranej gminy Tromsø). W module wykresu osi równoległych możliwa jest zmiana danych prezentowanych za pomocą poszczególnych osi. Można to zrobić, korzystając z zakładek, które zawierają przygotowane zestawy powiązanych wskaźników (np. wskaźniki ekspozycji), lub samodzielnie wybrać zestaw danych, jaki chcemy prezentować na kolejnych osiach. Sama kolejność osi może być również zmieniona przez użytkownika. Możliwe jest filtrowanie powiatów znajdujących się na liście umieszczonej na prawo od wykresu (ryc. 4.6 E, czerwona strzałka wskazuje powiat wybrany z listy). Innego rodzaju filtrowanie można przeprowadzić poprzez zaznaczenie zakresu wartości wskaźnika na wybranej osi (ryc. $4.6 \mathrm{~F}$, czerwona strzałka pokazuje wybrany zakres wartości indeksu ekspozycji: 50-60). W ten sposób zostają pokazane tylko linie reprezentujące jednostki o wartościach wybranego wskaźnika w określonym w ten sposób przedziale. Z kolei w module $z$ tabelą możliwa jest zmiana kolejności kolumn prezentujących poszczególne wskaźniki oraz porządkowanie (rosnąco lub malejąco) wierszy w tabeli według wybranego atrybutu.

\subsection{Uczestnicy badania}

W badaniu wzięło udział 29 uczestników (11 kobiet, 18 mężczyzn) w wieku od 22 do 41 lat (średnia wieku 27 lat). Liczebność uczestników została podyktowana zaleceniami, jakie znajdujemy w literaturze z zakresu badań użyteczności (Nielsen 1993), w tym z zastosowaniem metody eye tracking (Pernice i Nielsen 2009), a także jest zgodna ze sposobem projektowania innych badań użyteczności (w tym liczebnością prób) na gruncie geowizualizacji (Koua, MacEachren i Kraak 2006; Çöltekin i współautorzy 2009), co zostało poruszone w podrozdziale 3.2.

Wiedza i umiejętności czytania map tematycznych wydają się być ważnymi czynnikami, decydującymi o powodzeniu przy pracy z nieznanym narzędziem geowizualizacji, w tym $z$ testowanym opracowaniem 
o charakterze eksperckim. Dobór osób został zatem przeprowadzony z uwzględnieniem tych czynników. Zweryfikowano również, czy nikt z uczestników badania nie korzystał wcześniej z wieloelementowego narzędzia geowizualizacji. Do udziału w badaniu zaproszono osoby, które posiadają umiejętności i doświadczenie w czytaniu i interpretacji map. Byli to studenci studiów magisterskich (79\% uczestników badania) lub doktoranckich (21\%) z zakresu geografii Norweskiego Uniwersytetu Nauki i Technologii w Trondheim.

Na podstawie kwestionariusza uczestnicy określili na pięciostopniowej skali Likerta poziom swojego wykształcenia i doświadczenia na kilku płaszczyznach. Na skali tej 1 oznaczało brak przeszkolenia, 5 zaś - wykształcenie i wiedzę na poziomie profesjonalnym. Uczestnicy określili swoje przeszkolenie w zakresie kartografii średnio na poziomie 2.8, nieco gorzej ocenili swoją wiedzę z zakresu grafiki komputerowej (2.0), projektowania stron internetowych (1.5) oraz projektowania interfejsu użytkownika (1.7). Z kolei swoją wiedzę z zakresu systemów informacji geograficznej (GIS) uczestnicy ocenili najwyżej - średnio 3.0.

\subsection{Zadania}

Uczestnicy rozwiązywali w sumie sześć zadań. Pierwsze zadanie polegało na realizacji dowolnej eksploracji (ang. free examination). Pierwszy raz zadanie tego typu wykorzystał A.L. Yarbus (1967), który poprosił uczestników swojego badania o swobodne oglądanie obrazów, bez konkretnego celu. Umożliwiło mu to określenie, jak ludzie spontanicznie kierują swoją uwagę na różne fragmenty obrazów. Tego typu zadania były później stosowane w celu analizy fiksacji do oceny widoczności różnych elementów ilustracji (Humphrey i Underwood 2009; Borji, Sihite i Itti 2013). W kartografii i geowizualizacji ten rodzaj zadania był również z powodzeniem wykorzystywany w badaniach empirycznych (Dobson 1979; Demšar 2007; Opach, Gołębiowska i Fabrikant 2014; Dupont i współautorzy 2017).

Zadanie dowolnej eksploracji zostało sformułowane w następujący sposób: „Użyj narzędzia i popracuj z nim, aby je poznać. Mów głośno o wszystkim, co wydaje ci się interesujące i co wydaje ci się zniechęcające". Użytkownicy głośno wypowiadali swoje myśli i spostrzeżenia. W przypadku dłuższej chwili ciszy eksperymentator prosił o wznowienie głośnego myślenia. Takie grzeczne przypomnienia są praktyką często stosowaną w badaniach z wykorzystaniem metody głośnego myślenia.

Kolejne pięć zadań stanowiło część testową i miało formę pytań. Wymagały one odszukania za pomocą testowanego narzędzia wskazanej 
w pytaniu informacji. Pytania te odnosiły się do konkretnych operacji, które są realizowane w trakcie eksplorowania większych zestawów danych. Eksploracja taka może być postrzegana jako szereg prostych zadań (Koua i Kraak 2004; Koua, MacEachren i Kraak 2006), takich jak określanie położenia interesujących nas obiektów w celu obliczenia odległości pomiędzy nimi lub uzyskania oglądu, jakie wartości danej charakterystyki przyjmują obiekty w różnych miejscach. W celu wykonania tych zadań użytkownik realizuje różnego typu operacje wizualizacji (Tobón 2005). Operacje te są przydatne do oceny różnych geowizualizacji (Koua, MacEachren i Kraak 2006), aby sprawdzić, czy testowane narzędzia pomagają w ich realizacji. Spośród wielu dotychczas zaproponowanych klasyfikacji operacji wizualizacji (Roth 2012) w niniejszym badaniu została wykorzystana klasyfikacja autorstwa R. Amara, J. Eagana i J. Stasko (2005), która odnosi się do operacji podstawowych. Jest to zestawienie, które zostało opracowane przy pomocy użytkowników, w odróżnieniu od innych popularnych klasyfikacji, które były formułowane przez samego badacza (Roth 2012). W celu opracowania tej klasyfikacji autorzy poprosili grupę studentów kierunku wizualizacja informacji o analizę pięciu zestawów danych. W trakcie tego badania mieli oni sformułować listę operacji, jakie mogą za pomocą tych danych wykonać, określić, jakie hipotezy mogą być postawione, jakie zadania zrealizowane, jakie pytania odnoszące się do tych danych mogą być zadane. Zebrane odpowiedzi zostały następnie przeanalizowane metodą diagramu podobieństwa i pozwoliły na wyróżnienie dziesięciu różnych operacji wskazywanych przez studentów: odczytaj wartości, filtruj, przelicz odczytane wartości, znajdź wartości skrajne, uporządkuj, określ zakres wartości, scharakteryzuj zróżnicowanie, znajdź anomalie, pogrupuj, określ relacje. Wszystkie te operacje odnoszą się do analitycznych zadań o charakterze podstawowym. Na bazie tych operacji można następnie rozbudować bardziej złożone działania. Dzięki temu możliwe jest odniesienie tych operacji do innych klasyfikacji. Ponadto, mając na uwadze, że wieloelementowe geowizualizacje funkcjonują również w szerzej pojętej wizualizacji, posłużono się zestawieniem operacji, które odnoszą się do szerszego kontekstu, nie ograniczając się tylko do geowizualizacji. Z dziesięciu operacji wyróżnionych w propozycji R. Amara, J. Eagana i J. Stasko (2005) wybrano te, które mogą być realizowane przy użyciu wszystkich trzech form prezentacji zastosowanych w testowanym narzędziu. Zadania były tak sformułowane, by nie były nadmiernie rozbudowane ani uciążliwe. Zostały ułożone według wzrastającego poziomu trudności. Poziom ten określono za R.M. Edsallem (2003): uznano, że obciążenie poznawcze związane z realizacją zadania 
Tabela 4.1. Zadania realizowane w części testowej (przetłumaczone na język polski)

\begin{tabular}{|c|c|c|c|}
\hline \multirow{2}{*}{ Treść polecenia } & $\begin{array}{l}\text { Rodzaj } \\
\text { operacji }\end{array}$ & Opis & \multirow{2}{*}{$\begin{array}{l}\text { Liczba } \\
\text { zmiennych }\end{array}$} \\
\hline & \multicolumn{2}{|c|}{$\begin{array}{c}\text { według R. Amara, J. Eagana } \\
\text { i J. Stasko (2005) }\end{array}$} & \\
\hline $\begin{array}{l}\text { Jaka jest wartość indeksu } \\
\text { Ekspozycji na Powodzie } \\
\text { w gminie Trondheim? }\end{array}$ & $\begin{array}{c}\text { Odczytaj } \\
\text { wartości } \\
\text { (Retrieve value) }\end{array}$ & $\begin{array}{c}\text { Podaj wartość } \\
\text { wskazanego atrybutu } \\
\text { dla konkretnego } \\
\text { obiektu }\end{array}$ & $\begin{array}{l}\text { jeden } \\
\text { obiekt, } \\
\text { jeden } \\
\text { atrybut }\end{array}$ \\
\hline $\begin{array}{l}\text { Podaj nazwy trzech gmin, } \\
\text { które charakteryzują się } \\
\text { wartością powyżej } 85 \text { dla } \\
\text { Zintegrowanego Indeksu } \\
\text { Podatności }\end{array}$ & $\begin{array}{l}\text { Filtruj } \\
\text { (Filter) }\end{array}$ & $\begin{array}{l}\text { Mając podane pewne } \\
\text { wartości atrybutu, } \\
\text { znajdź obiekty, które } \\
\text { spełniają wskazany } \\
\text { warunek }\end{array}$ & $\begin{array}{l}\text { trzy obiekty, } \\
\text { jeden } \\
\text { atrybut }\end{array}$ \\
\hline $\begin{array}{l}\text { Jak zmienia się Indeks } \\
\text { Ekspozycji na obszarze } \\
\text { powiatu Finnmark? }\end{array}$ & $\begin{array}{l}\text { Scharakteryzuj } \\
\text { zróżnicowanie } \\
\text { wartości } \\
\text { (Characterize } \\
\text { distribution) }\end{array}$ & $\begin{array}{l}\text { Scharakteryzuj } \\
\text { zróżnicowanie } \\
\text { określonego atrybutu } \\
\text { we wskazanym } \\
\text { zestawie obiektów }\end{array}$ & $\begin{array}{l}\text { wiele } \\
\text { obiektów, } \\
\text { jeden } \\
\text { atrybut }\end{array}$ \\
\hline $\begin{array}{l}\text { Wskaż jedną cechę wspólną } \\
\text { dla wszystkich gmin, } \\
\text { które posiadają wartości } \\
\text { wskaźnika Ekspozycja } \\
\text { na Burze poniżej 20? }\end{array}$ & $\begin{array}{l}\text { Określ relacje } \\
\text { (Correlate) }\end{array}$ & $\begin{array}{c}\text { Określ, jakie } \\
\text { są relacje we } \\
\text { wskazanym zestawie } \\
\text { obiektów dla dwóch } \\
\text { atrybutów }\end{array}$ & $\begin{array}{l}\text { wiele } \\
\text { obiektów, } \\
\text { dwa } \\
\text { atrybuty }\end{array}$ \\
\hline $\begin{array}{l}\text { Czy w powiecie Sogn } \\
\text { og Fjordane są gminy, } \\
\text { które odróżniają się od } \\
\text { pozostałych w tym powiecie } \\
\text { pod względem ekspozycji } \\
\text { na któreś z zagrożeń } \\
\text { naturalnych? }\end{array}$ & $\begin{array}{c}\text { Znajdź anomalie } \\
\text { (Find } \\
\text { anomalies) }\end{array}$ & $\begin{array}{l}\text { Zidentyfikuj anomalie } \\
\text { we wskazanym } \\
\text { zestawie obiektów } \\
\text { w odniesieniu } \\
\text { do określonych } \\
\text { atrybutów }\end{array}$ & $\begin{array}{l}\text { wiele } \\
\text { obiektów, } \\
\text { wiele } \\
\text { atrybutów }\end{array}$ \\
\hline
\end{tabular}

wzrasta wraz z liczbą atrybutów (zestawów danych) i wraz ze złożonością aspektu przestrzennego (liczby obiektów, których zadanie dotyczy). Dlatego poziom obciążenia poznawczego jest najniższy w przypadku zadania 1 , które odnosi się do jednej zmiennej tematycznej oraz jednego obiektu, a najwyższy - w przypadku ostatniego zadania, które odwołuje się do kilku zmiennych tematycznych oraz wielu obiektów (tab. 4.1). Wszystkie pytania miały charakter otwarty, a uczestnicy badania odpowiadali na nie słownie. Po udzieleniu odpowiedzi przyciskali klawisz „Dalej” (ryc. 4.5), który umożliwiał wyświetlenie kolejnego zadania oraz ponowne wczytanie narzędzia z domyślnymi ustawieniami. 


\subsection{Przyjęte metody badawcze}

Zgodnie z zaleceniem B. Buttenfield (1999), według którego łączenie metod jest niezbędnym podejściem w przypadku badania złożonych interfejsów geowizualizacji, wykorzystanych zostało kilka metod. W trakcie zadania dowolnej eksploracji narzędzia zastosowano następujące metody: eye tracking, rejestr interakcji (interaction logs) (Behrens, van Elzakker i Schmidt 2015) oraz protokoły głośnego myślenia (Ericsson, Anders i Simon 1980; Ericsson i Simon 1993) (ryc. 4.7). Rejestr interakcji polega na zapisie kolejnych funkcji interaktywnych wykorzystanych w trakcie pracy z danym narzędziem. Dotyczy to zarówno funkcji uruchamianych za pomocą kliknięcia myszy (prawym i lewym klawiszem), jak i rolki myszy czy klawiatury. Z kolei metoda protokołów głośnego myślenia polega na poproszeniu uczestników o werbalizację wszystkich swoich myśli podczas rozwiązywania zadania. Wypowiedzi te są nagrywane, a potem analizowane. Często te wypowiedzi, czyli dane o charakterze jakościowym, kwantyfikuje się za pomocą kodowania (Chi 1997). Wypowiedzi dzieli się na elementy, a następnie przypisuje się kategorię kodu z klucza opracowanego na potrzeby analizy (Gołębiowska 2015).

Zestawienie dwóch metod, protokołów głośnego myślenia i eye tracking w zadaniu dowolnej eksploracji, wymaga komentarza. Metoda głośnego myślenia służy najczęściej do określenia przyjętych strategii rozwiązywania złożonych problemów (Howard i MacEachren 1996; Gołębiowska 2015), ale również wykazana została przydatność tej metody do uzyskania od badanych komentarzy na temat testowanego interfejsu (Robinson i współautorzy 2005). Mogą pojawić się obawy dotyczące ograniczeń wynikających z jednoczesnego wykorzystania metod eye tracking i protokołów głośnego myślenia. Werbalizowanie myśli podczas rozwiązywania zadania może modyfikować i zniekształcać informacje na temat uwagi wizualnej, ponieważ „mowa jest wolniejsza niż oko". W konsekwencji może to nawet modyfikować uzyskane odpowiedzi. $Z$ drugiej jednak strony jest to niezwykle cenne zestawienie sposobów badania, ponieważ takie połączenie metod daje wgląd $w$ motywacje osoby badanej, dostarczając informacji na tematów powodu, dla którego badany skupia wzrok na tym, a nie innym miejscu. Warto zaznaczyć, że prowadzono już badania z zakresu geowizualizacji, które z sukcesem łączyły te metody (Dupont i współautorzy 2017). Ponadto w zadaniu, w którym zestawione zostały te dwie metody (zadanie dowolnej eksploracji), nie oczekiwano od badanych żadnej odpowiedzi, poprawnej bądź niepoprawnej, ani jej uzasadnienia. Analizowany był jedynie proces 


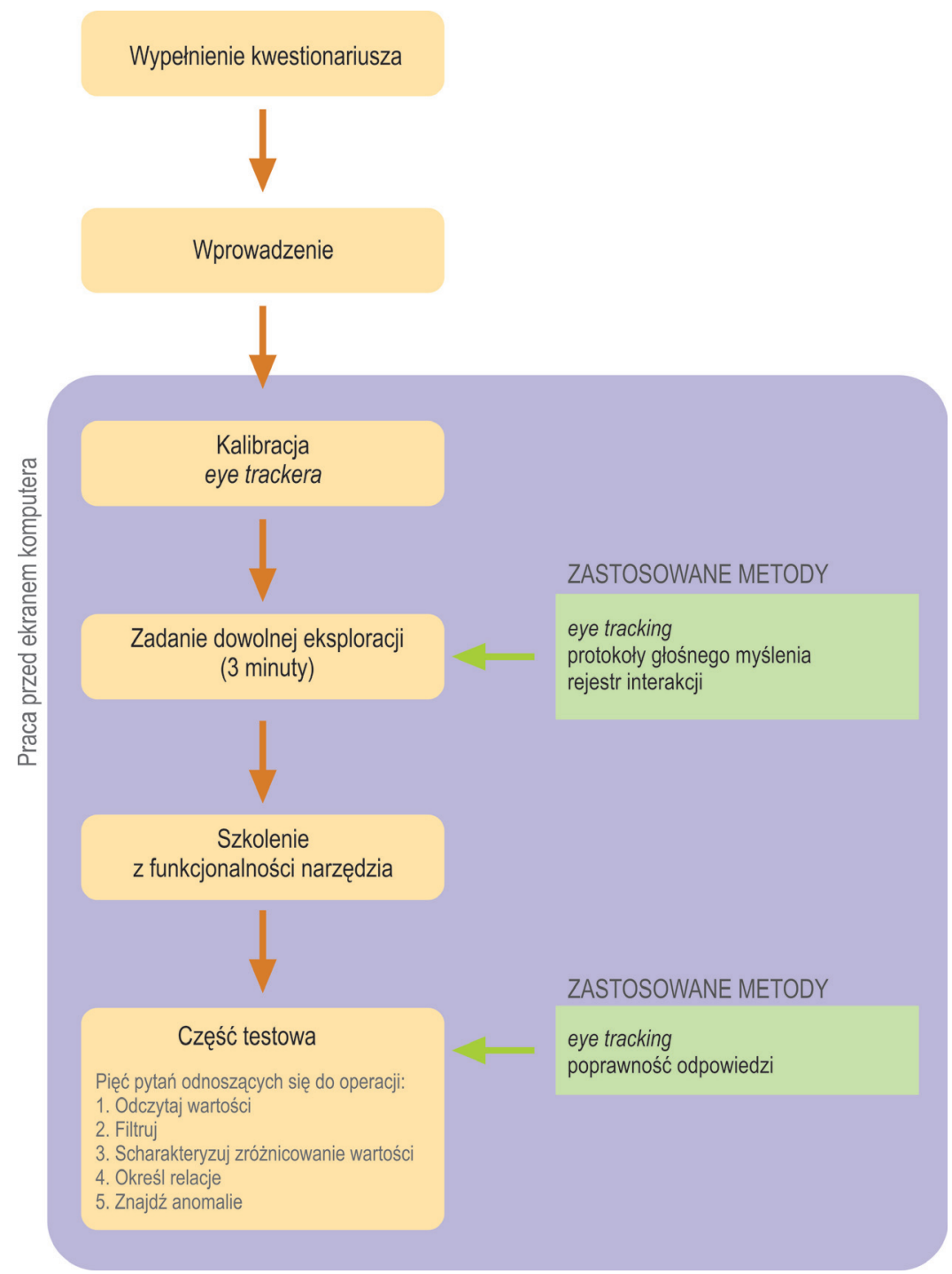

Rycina 4.7. Etapy badania oraz wykorzystane metody zbierania danych

spontanicznego studiowania interfejsu i zestawienie tych dwóch metod wydaje się być wyjątkowo wartościowym źródłem informacji na temat tego procesu. Informacje te nie mogłyby być uzyskane przez zastosowanie retrospektywnych protokołów głośnego myślenia, gdyby badani byli proszeni o próbę odtworzenia myśli i uzasadnienia swoich działań dopiero po skończeniu zadania dowolnej eksploracji. Werbalizacja odbywałaby się w trakcie oglądania nagrań wideo oraz wizualizacji ruchu oczu. W takim 
przypadku wiele ważnych informacji mogłoby być zapomnianych (van Gog i współautorzy 2005).

W trakcie odpowiadania na pięć pytań w części testowej (ryc. 4.6) wykorzystano eye tracking oraz jeden ze wskaźników użyteczności (poprawność odpowiedzi). W analizach nie uwzględniono czasu odpowiedzi, ponieważ ten wskaźnik użyteczności przy narzędziach interaktywnych okazuje się nie być wskaźnikiem właściwym, gdyż jest obarczony pewnym błędem. Badani mają tendencję do eksplorowania dostępnych funkcji interaktywnych, manipulowania danymi za pomocą różnych funkcji (nie zawsze bezpośrednio związanych z poszukiwaną informacją), co wydłuża czas udzielania odpowiedzi. Tendencja ta została potwierdzona w badaniach, w których porównywano mapy interaktywne z opracowaniami opublikowanymi za pomocą innego medium (Dong i współautorzy 2020a; Słomska 2021). Do zebrania podstawowych danych o użytkownikach i ich doświadczeniu oraz wykształceniu użyto kwestionariusza.

\subsection{Procedura}

Badanie odbyło się w trakcie indywidualnych sesji z użytkownikami. Można je podzielić na kilka etapów (ryc. 4.7). Po przywitaniu uczestnik wypełniał kwestionariusz, podając podstawowe dane dotyczące wieku, płci, wykształcenia oraz doświadczenia w używaniu map i innych geowizualizacji. Następnie był pokrótce informowany o celu badania, a także o warunkach uczestnictwa: udział w badaniu jest bezpłatny, dobrowolny i można je w każdej chwili przerwać, a zebrane dane będą przetwarzane w anonimowej formie. Badany zajmował wskazane miejsce przed ekranem komputera i następowała 5-punktowa kalibracja eye trackera. Po pomyślnej kalibracji uczestnik badania wykonywał przez 3 minuty zadanie „dowolnej eksploracji" (swobodne poznawanie, oglądanie i korzystanie z narzędzia bez żadnego zadania do rozwiązania). Limit 3 minut został ustanowiony na podstawie wyników sesji pilotażowych, z których wynikało, że swobodna i spontaniczna praca przez dłużej niż 3 minuty może powodować znużenie. Uczestnicy nie byli poinformowani o limicie czasowym w tym zadaniu, aby uniknąć pośpiechu, który mógłby się negatywnie odbić na ich działaniach.

Po zakończeniu pierwszego zadania uczestnik był instruowany, jak działa aplikacja, jakie są jej treść i funkcjonalność. Szkolenie to było ujednolicone dla każdego badanego. Kolejnym etapem była część testowa, w której badani rozwiązywali pięć zadań różnego typu. Całe badanie odbyło się w języku angielskim, wszyscy badani zadeklarowali płynne posługiwanie się tym językiem. 


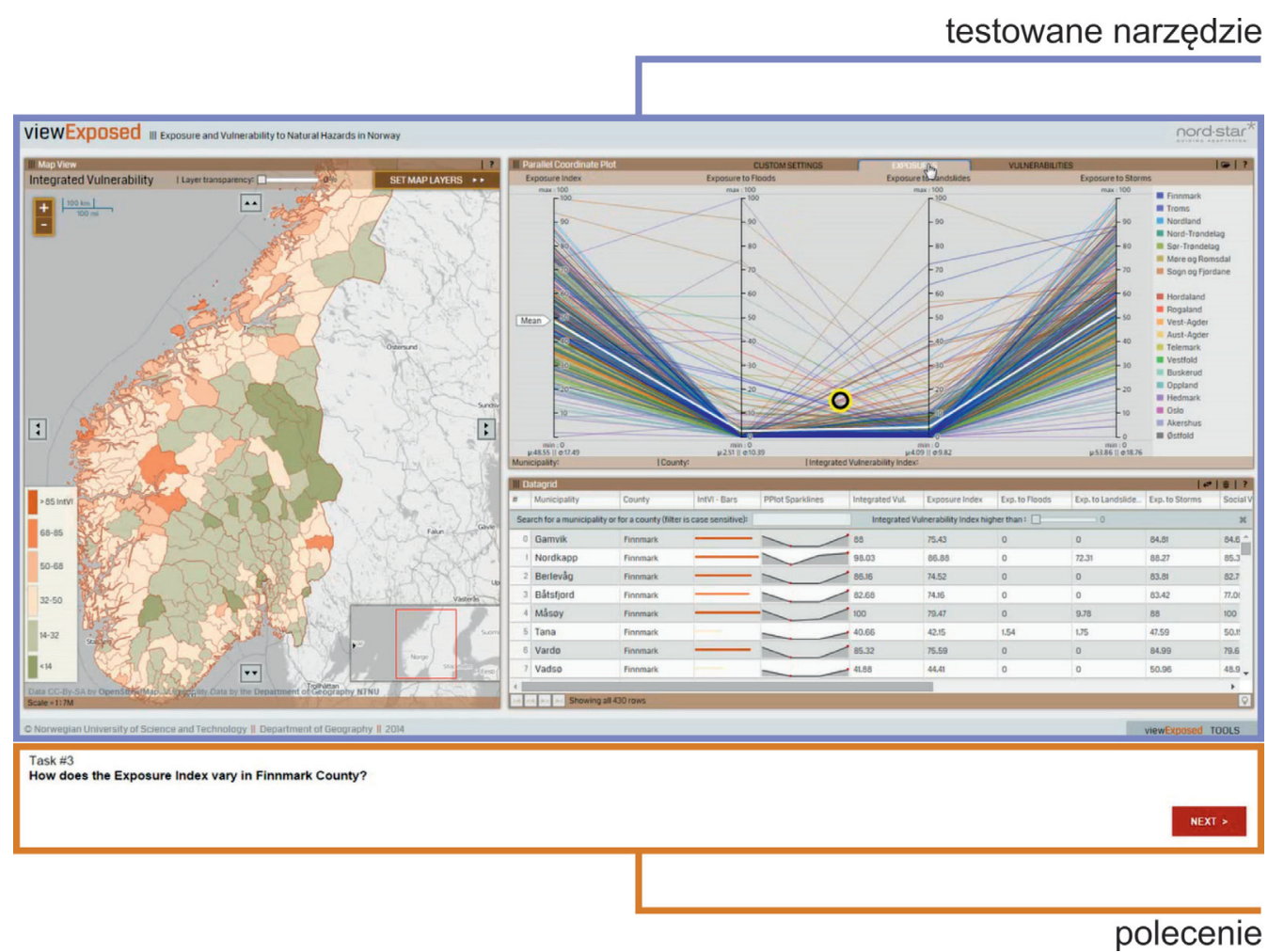

Rycina 4.8. Ekran w części testowej badania, w którym na dole ekranu była prezentowana treść pytania, a w prawym dolnym narożniku znajdował się przycisk „Dalej” umożliwiający przejście do kolejnego polecenia

\subsection{Wyposażenie}

Badanie odbyło się w pomieszczeniu o kontrolowanych warunkach: Laboratorium SCaLa (the Speech, Cognition and Language Laboratory) Zakładu Psychologii Norweskiego Uniwersytetu Nauki i Technologii w Trondheim. Wykorzystano eye tracker SMI RED500 z częstotliwością pomiaru ustawioną na $120 \mathrm{~Hz}$. Obraz wraz z zadaniami był wyświetlany na 21-calowym monitorze o rozdzielczości $1680 \times 1024$ pikseli. Wszystkie polecenia i instrukcje wyświetlane były na monitorze za pomocą przeglądarki Chrome. W części dowolnej eksploracji narzędzie było wyświetlane na całym ekranie, w części testowej z kolei część ekranu była zajęta przez treść kolejnych poleceń. Zadania w części testowej były umieszczone bezpośrednio pod narzędziem, na dole ekranu (ryc. 4.8). 


\subsection{Analiza danych}

Po zebraniu danych zastosowano szereg metod ich analizy. W celu analizy ruchu oczu badanych wyróżniono w pierwszej kolejności obszary zainteresowań (Areas of Interests, AOI), które odpowiadają poszczególnym modułom (ryc. 4.1). W zadaniu dowolnej eksploracji narzędzie było wyświetlane na całym ekranie. Udział procentowy poszczególnych modułów był następujący: moduł mapy - 38.7\% powierzchni ekranu, moduł wykresu osi równoległych - 35.4\%, moduł tabeli zaś - $24.1 \%$. Pozostałe $1.8 \%$ powierzchni ekranu było zajęte przez elementy przeglądarki internetowej (np. adres WWW). W trakcie rozwiązywania pięciu zadań stanowiących część testową na dole ekranu umieszczony został pasek z treścią polecenia, przez co mapa obejmowała 33\% ekranu, wykres osi równoległych - 31\%, tabela - 20\%, AOI „Zadanie” zaś $14 \%$ ekranu. Poszczególne moduły zajmowały więc inną część ekranu w zadaniu dowolnej eksploracji oraz drugiej (testowej) części badania.

Do analizy danych eye tracking użyto programu SMI BeGaze: obliczono za jego pomocą fiksacje oraz wskaźniki eye tracking. Analizy statystyczne przeprowadzono w programie SPSS. Analiza dopasowania sekwencji fiksacji na poszczególne moduły została przeprowadzona przy pomocy programu ClustalG (Wilson 2008). Z kolei analizy weryfikujące wyniki uzyskane poprzez procedurę dopasowania sekwencji przeprowadzono w aplikacji EMAAT (Eye Movement AOI Aggregation Tool), autorskiej aplikacji Tomasza Opacha opracowanej na Wydziale Geografii Norweskiego Uniwersytetu Nauki i Technologii. 


\section{Wyniki}

\subsection{Sposób poznawania nieznanego wieloelementowego narzędzia geowizualizacji}

\subsubsection{Uwaga wizualna w trakcie dowolnej eksploracji}

W celu określenia, który moduł przyciągnął uwagę badanych przy pierwszym kontakcie z narzędziem oraz jak badani dzielili swoją uwagę na moduły, porównane zostały następujące wskaźniki: czas do pierwszej fiksacji oraz całkowity czas fiksacji dla każdego AOI.

Tabela 5.1. Czas do pierwszej fiksacji oraz długość fiksacji na poszczególnych modułach testowanego opracowania (* oznacza różnice statystyczne na poziomie $p<0.05$ )

\begin{tabular}{|c|c|c|c|}
\hline & Mapa & $\begin{array}{l}\text { Wykres osi } \\
\text { równoległych }\end{array}$ & Tabela \\
\hline & $\begin{array}{c}\text { średnia } \\
\text { (odch. stand.) } \\
\text { [sek.] }\end{array}$ & $\begin{array}{c}\text { średnia } \\
\text { (odch. stand.) } \\
\text { [sek.] }\end{array}$ & $\begin{array}{c}\text { średnia } \\
\text { (odch. stand.) } \\
\text { [sek.] }\end{array}$ \\
\hline czas do pierwszej fiksacji & $\begin{array}{c}1.7 \\
(3.6)\end{array}$ & $\begin{array}{c}0.8 \\
(2.1)\end{array}$ & $\begin{array}{c}3.6 \\
(6.4)\end{array}$ \\
\hline \multicolumn{4}{|c|}{$\longleftarrow$} \\
\hline długość fiksacji & $\begin{array}{c}55.2 \\
(25.4)\end{array}$ & $\begin{array}{c}50.4 \\
(20.7)\end{array}$ & $\begin{array}{c}38.4 \\
(22.3)\end{array}$ \\
\hline
\end{tabular}

Wykres osi równoległych przyciągnął uwagę badanych w pierwszej kolejności (tabela 5.1). Moduł ten cechuje się najkrótszym średnim czasem do pierwszej fiksacji ( 0.8 sekundy), tabela z kolei była tym elementem, na którym badani koncentrowali wzrok najpóźniej (średni czas do pierwszej fiksacji wynosił 3.6 sekundy). Jednokierunkowa 
analiza wariancji ANOVA wykazała różnice istotne statystyczne pomiędzy czasem do pierwszej fiksacji na wykresie osi równoległych oraz na tabeli $(F=3.123, p<0.05)$. Najkrócej oglądana była tabela (średni czas fiksacji 38.4 sekundy), mapa i wykres zaś były oglądane przez podobny czas (odpowiednio: 55.2 sekundy oraz 50.4 sekundy). Różnice w długości fiksacji pomiędzy modułami nie były istotne statystycznie $(\mathrm{F}=3.123, p>0.05)$.

Pomimo że moduły oglądane były przez podobny czas, to badani skupiali wzrok na różnych elementach poszczególnych modułów. Rycina 5.1 pokazuje średni czas fiksacji w poszczególnych miejscach interfejsu. W obrębie mapy można wyróżnić kilka obszarów wzmożonej uwagi, na których czas fiksacji był wyraźnie dłuższy (ryc. 5.1 A-D). Oglądając moduł mapy, badani patrzyli na środkową jego część, analizując obszar, który był prezentowany $w$ danym momencie na środku mapy (ryc. 5.1 A). Legenda mapy, zwłaszcza jej górna część (ryc. 5.1 B) to kolejne miejsce z dłuższym czasem fiksacji. Dwa inne obszary, na których badani dłuższej koncentrowali swój wzrok, to miejsca, gdzie po naciśnięciu odpowiedniego klawisza lub obiektu - pojawiały się dodatkowe okna: okno z informacjami o wybranej jednostce podziału administracyjnego (ryc. $5.1 \mathrm{C}$ ) oraz lista wyboru mapy tematycznej po naciśnięciu przeznaczonego do tego klawisza (ryc. 5.1 D). Oglądając pozostałe moduły, wykres i tabelę, badani koncentrowali uwagę na obszarach położonych w brzeżnych partiach ekranu, w których znajdowały się różnego typu elementy objaśniające. W obrębie wykresu osi równoległych badani koncentrowali wzrok na opisach osi oraz nazwach zakładek, pod którymi zestawiono różne indeksy (ryc. $5.1 \mathrm{E}$ ). Drugim miejscem dłuższej koncentracji wzroku była lista powiatów (ryc. 5.1 F). Podobnie w module tabeli: miejsca większej koncentracji wzroku to opisy: nazwy kolumn (ryc. $5.1 \mathrm{G}$ ) oraz pierwsza kolumna z nazwami gmin (ryc. $5.1 \mathrm{H}$ ).

Powyższe analizy pokazują miejsca koncentracji uwagi badanych w czasie trwania zadania, czyli w ciągu trzech minut. Nie uwzględniają jednak zmian uwagi wizualnej w tym czasie. Dlatego też przeprowadzono analizę wskaźników eye tracking w przedziałach wydzielonych w równych interwałach czasowych, na które podzielono czas trwania zadania. Czas ten podzielono na sześć przedziałów o długości 30 sekund i dla każdego przedziału obliczono średnią długość fiksacji na każdym z modułów oraz liczbę sakkad pomiędzy modułami (ryc. 5.2). W trakcie trwania zadania badani przenosili uwagę na różne miejsca, w konsekwencji różne moduły cechowały się najdłuższymi fiksacjami w różnych interwałach. Początkowo, w czasie pierwszych 30 sekund trwania zadania 


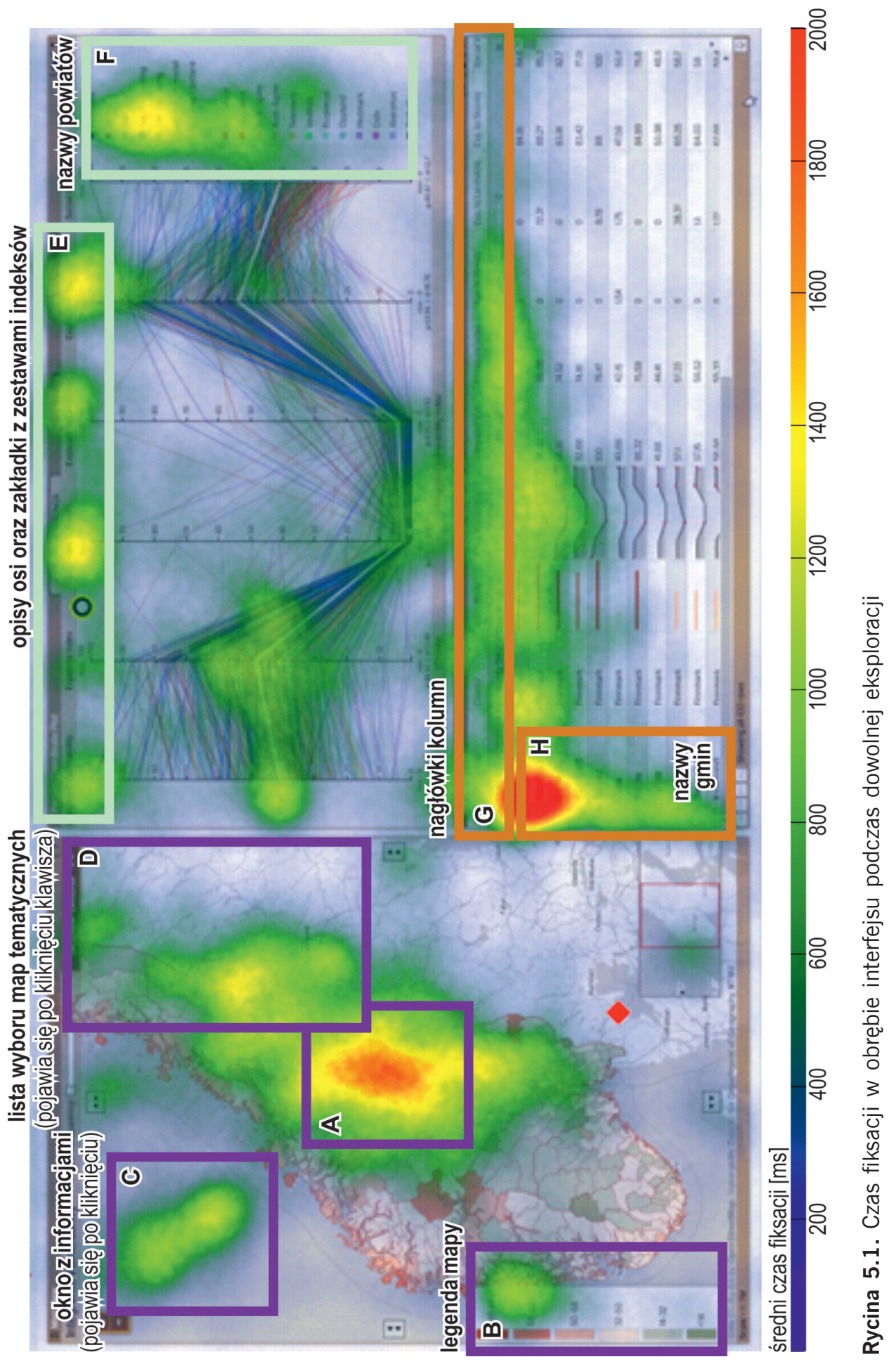



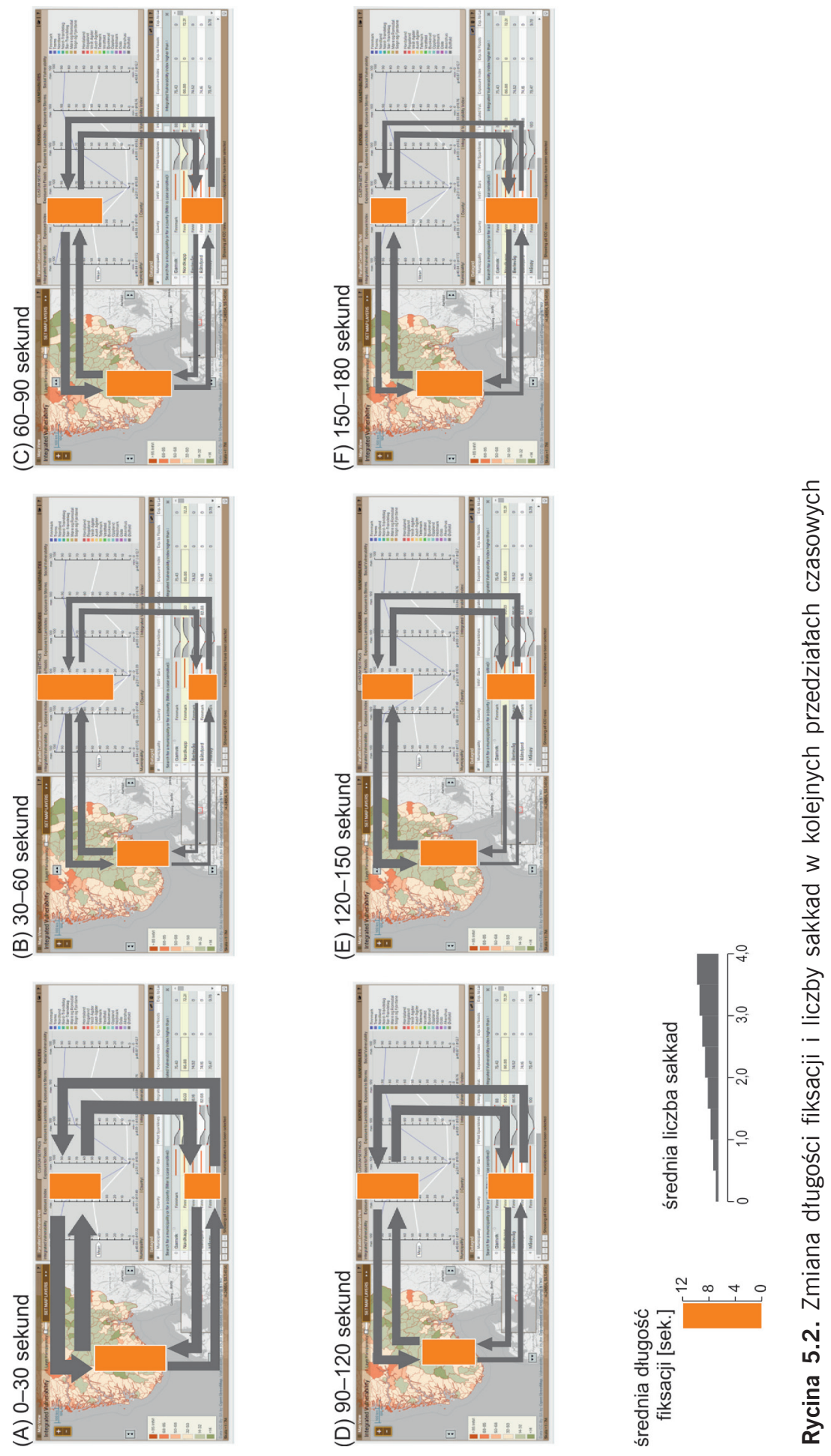
(ryc. 5.2 A), badani najczęściej koncentrowali wzrok na mapie (średnia długość fiksacji 10.8 sekund) i jednocześnie przenosili często wzrok pomiędzy modułami, co skutkowało wysoką liczbą sakkad między nimi. $\mathrm{Na}$ dalszym etapie zadania badani koncentrowali wzrok na wykresie osi równoległych (interwał 30-60 sekund oraz 90-120 sekund, ryc. 5.2 B i D). Dopiero w późniejszych interwałach badani przenosili uwagę na tabelę, w ostatnim interwale 150-180 sekund (ryc. 5.2 F) długość fiksacji na tabeli wynosiła 7.9 sekund.

\subsubsection{Wykorzystanie funkcji interaktywnych}

Uczestnicy badania potrzebowali pewnego czasu, zanim zdecydowali się na użycie narzędzi interaktywności. Początkowo tylko patrzyli i analizowali interfejs, nie próbując skorzystać z żadnej funkcji interaktywnej. Potrzebowali średnio ponad jednej minuty, aby zdecydować się na kliknięcie myszą: średni czas do pierwszego kliknięcia myszą wynosi 61.4 sekundy (odch. stand. 40.1). Mapa jest modułem, w który zdecydowano się kliknąć w pierwszej kolejności (średni czas do pierwszego kliknięcia 45.4 sekundy, odch. stand. 31.8). W dalszej kolejności był to wykres (średnio 67.1 sekundy, odch. stand. 44.2), a w ostatniej tabela (średnio 71.5 sekundy, odch. stand. 44.3).

Pewien brak zdecydowania użytkowników w zakresie eksplorowania funkcji interaktywnych widać również w statystykach dotyczących odsetka badanych, którzy kliknęli bądź nie kliknęli w poszczególne moduły. Wszyscy badani kliknęli chociaż w jeden moduł, jednak 7\% uczestników kliknęło tylko w jeden moduł (wykres lub mapę), z kolei aż 38\% badanych - tylko w dwa moduły. Byli więc użytkownicy, którzy nie podjęli się interakcji z poszczególnymi modułami: $21 \%$ badanych nie kliknęło w mapę, $17 \%$ nie zdecydowało się kliknąć w wykres osi równoległych, 14\% badanych zaś nie kliknęło ani razu w tabelę.

Tylko jeden użytkownik skorzystał z klawisza, pod którym znajdowały się samouczki do poszczególnych modułów. Pozostali badani zdecydowali się na samodzielne poznawanie narzędzia, pomimo widocznego i podpisanego klawisza z samouczkiem. Użytkownicy w trakcie swobodnej eksploracji korzystali prawie wyłącznie z lewego klawisza myszy (był tylko jeden przypadek użycia prawego klawisza myszy).

Najczęściej stosowane funkcje realizowane były bez konieczności korzystania z klawiszy do tego przeznaczonych (funkcje oznaczone czerwonym konturem słupków na ryc. 5.3 należą do rzadziej wykorzystywanych we wszystkich modułach). Również porównując udział osób, 


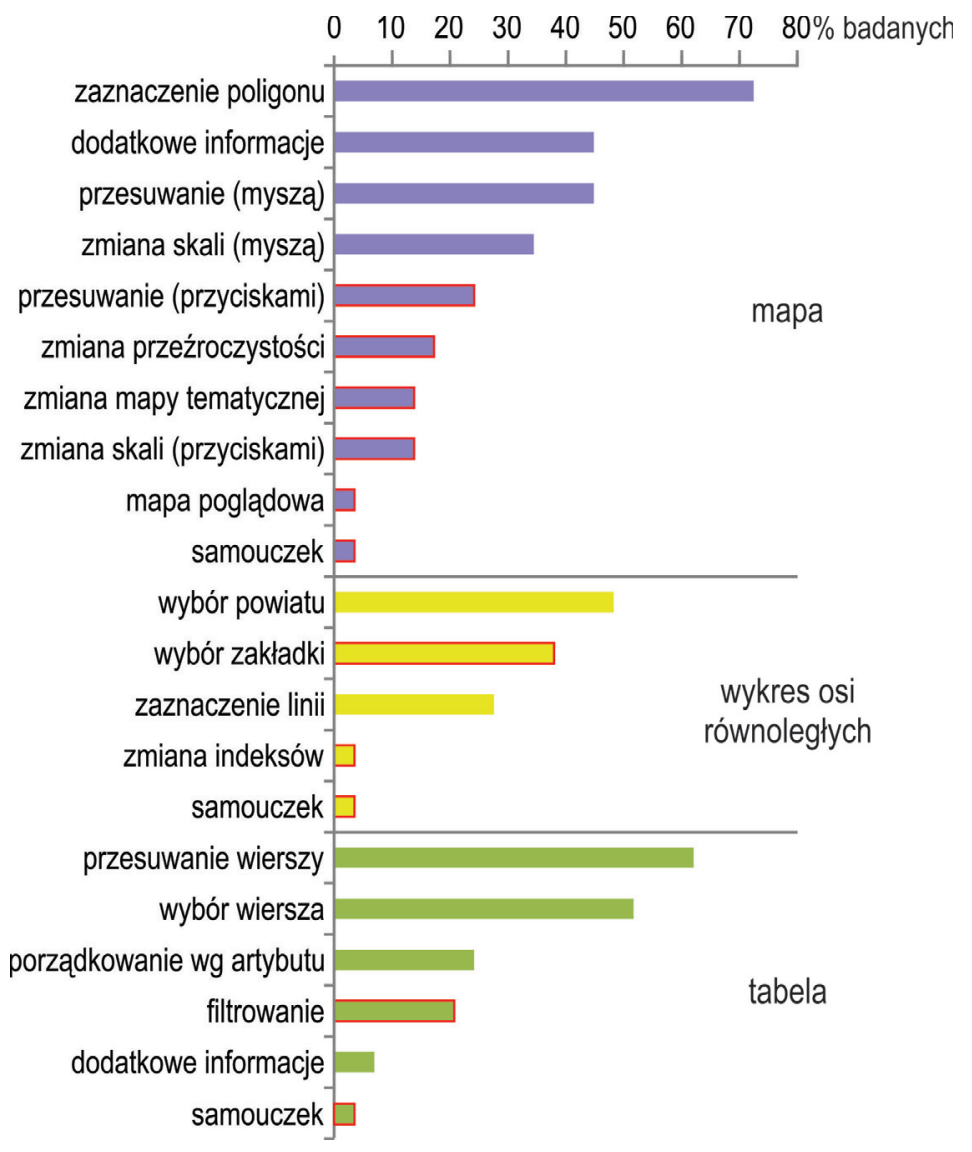

Rycina 5.3. Zakres wykorzystania funkcji interaktywnych w trakcie swobodnej eksploracji narzędzia. Czerwonym konturem słupków oznaczono funkcje realizowane poprzez odpowiednie klawisze w obrębie interfejsu

które skorzystały z funkcji zmiany skali i zmiany zasięgu za pomocą myszy lub przycisku, można wysnuć wniosek, że około dwa razy więcej osób skorzystało z opcji modyfikacji narzędzia za pomocą myszy: $45 \%$ badanych użyło myszy do zmiany zasięgu mapy, podczas gdy $24 \%$ badanych skorzystało z przycisku do tego celu; dla funkcji zmiany skali mapy te wartości wynoszą odpowiednio: 34\% dla modyfikacji samą myszą oraz $14 \%$ dla zmiany skali za pomocą przycisków. Potwierdza to wnioski S.M. Mansona i współautorów (2012) dotyczące preferencji pracy myszą w porównaniu z używaniem przycisków w obrębie interfejsu. Jednocześnie jest to wskazówka, w jaki sposób można uprościć interfejs: poprzez pominięcie przycisków realizujących funkcje, które użytkownicy chętniej wykonują tylko za pomocą myszy. 
Na podstawie analizy rejestru interaktywności wyróżnionych zostało 21 funkcji interaktywnych, które były wykorzystane przez badanych z różną intensywnością (rycina 5.3). Funkcje te nie odnoszą się do konkretnej klasyfikacji funkcji interaktywnych - w przeciwieństwie do zadań, które zostały odniesione do klasyfikacji operacji R. Amara, J. Eagana i J. Stasko (2005), lecz bezpośrednio do funkcji zastosowanych w testowanym narzędziu. Wyróżnione funkcje interaktywne zostały zestawione w celu określania zakresu wykorzystania dostępnej interaktywności w trakcie spontanicznej eksploracji.

Trzy funkcje interaktywne były wykorzystane przez większość badanych osób. Były to: zaznaczenie gminy na mapie, przesuwanie wierszy oraz wybranie wiersza w tabeli. Najczęściej stosowaną operacją interaktywną było zaznaczenie na mapie poligonu. Z funkcji tej skorzystało w sumie $72 \%$ uczestników badania. Badani również często odczytywali dodatkowe informacje o gminach poprzez najeżdżanie na nie kursorem oraz zmieniali zasięg mapy przy użyciu lewego klawisza myszy (z obu tych funkcji skorzystało $45 \%$ badanych). Funkcje często wykorzystywane w module mapy to zmiana jej skali za pomocą rolki myszy oraz zmiana zasięgu mapy za pomocą klawiszy interfejsu. Ponad połowa badanych zaznaczyła pojedynczą gminę na mapie ( $72 \%$ badanych) oraz w tabeli (52\%), znacznie mniej osób zrobiło to za pomocą modułu wykresu zaledwie $27 \%$ osób. Tak niski odsetek może wynikać z nakładania się linii na wykresie, co utrudnia operację i łatwiej to uczynić za pomocą pozostałych modułów. Prawie połowa badanych (48\%) wybrała powiat $\mathrm{z}$ listy znajdującej się $\mathrm{w}$ obrębie modułu wykresu. Funkcja ta powoduje filtrowanie linii na wykresie: wyświetlane są tylko te, które reprezentują gminy położone w wybranym powiecie. Poprawia to czytelność wykresu (Heinrich i Weiskopf 2013) i ułatwia pracę z tym modułem. Dość duży odsetek badanych (37\%) wybierał zakładki, które powodowały wyświetlenie odpowiednio dobranych zestawów indeksów. Eksplorując moduł tabeli, uczestnicy najczęściej przesuwali wiersze (62\% badanych). $24 \%$ badanych sprawdziło, jak można porządkować dane według wybranego atrybutu oraz je filtrować według zintegrowanego indeksu podatności w postaci suwaka.

\subsubsection{Komentarze uczestników badania}

Na podstawie nagrań werbalizacji myśli badanych opracowano protokoły, które zakodowano w zależności od tego, czy uzyskano komentarz pozytywny, negatywny czy też neutralny. Negatywne komentarze stanowiły 
$39 \%$ wypowiedzi. Badani przedstawiali w nich swoje pierwsze wrażenia - zdezorientowanie z powodu pojawienia się jednocześnie tak wielu elementów:

„Może to być nieco przytłaczające, ponieważ wiele rzeczy wyskakuje na raz, pojawia się. Ludzie mogą się trochę przestraszyć" (Badany 29).

Wyrazili jednocześnie potrzebę wyraźnej wskazówki, od czego zacząć pracę $\mathrm{z}$ tak złożonym narzędziem, np.:

„Jest trudno określić, od czego zacząć" (Badany 2).

Negatywne komentarze często odnosity się do wykresu osi równoległych, który był określany jako niezrozumiały i trudny do odczytania z powodu nagromadzenia zbyt wielu linii prezentowanych jednocześnie, co uniemożliwiało znalezienie poszczególnej linii:

„To jest bardzo trudne. Nie jestem przeszkolony, jak czytać takie rzeczy” (Badany 18).

Badani stwierdzili, że ta forma prezentacji wymaga dodatkowego instruktażu, aby była zrozumiała.

Niewiele mniej, bo 37\% wypowiedzi miało charakter pozytywny. Gdy tylko użytkownicy zaczęli manipulować elementami narzędzia, przyznali, że jest ono łatwiejsze w użyciu, niż początkowo przypuszczali. Ważne w tym wypadku było zorientowanie się, że moduły są interaktywnie ze sobą połączone:

„Jest to dobre, kiedy już zaczniesz pracować, ponieważ masz mapę, która pokazuje ci najbardziej zagrożone miejsca, a tutaj masz więcej w innych oknach, aby zrozumieć więcej" (Badany 26).

Jednak uczestnicy badania uznali, że potrzebowali nieco czasu, by zrozumieć, w jaki sposób działają połączenia między oknami. Wskazywali również na pożyteczną funkcję filtrowania linii na wykresie osi równoległych:

„Podoba mi się ta interaktywność, że jak kliknę na gminę (na mapie), to widzę zagrożenia, na które jest wystawiona (na wykresie)" (Badany 17).

24\% wypowiedzi miało charakter neutralny. Do tego typu stwierdzeń można zaliczyć odczytywanie na głos opisów umieszczonych w obrębie interfejsu lub przywoływanie osobistych refleksji na temat obszaru Norwegii prezentowanego aktualnie na mapie. 


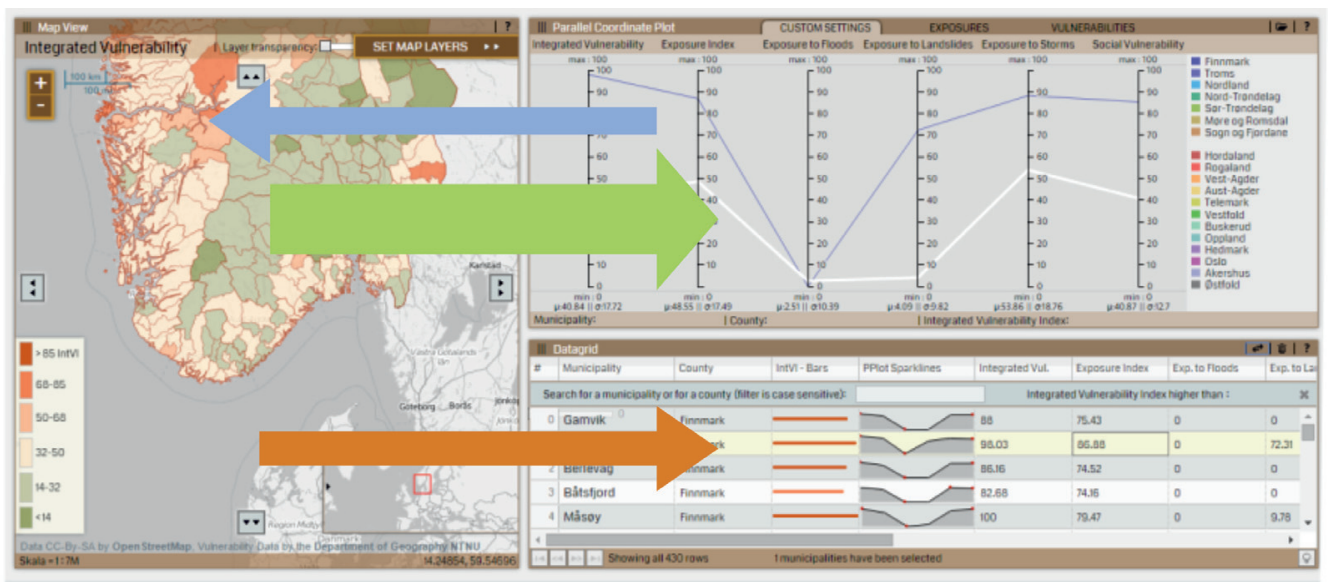

$\%$ badanych

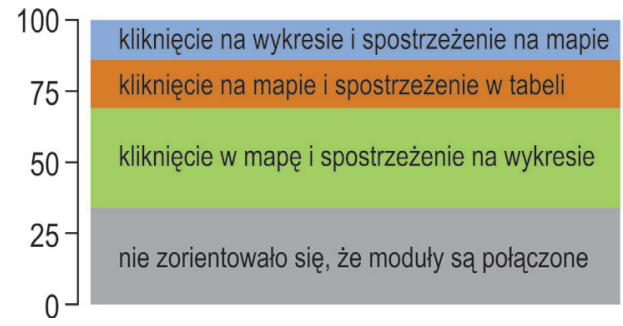

Rycina 5.4. Sposób, w jaki badani rozpoznali połączenie między modułami

Badani deklarowali, że zorientowanie się, że moduły są połączone ze sobą, było kluczowe dla postrzegania narzędzia jako mniej trudnego, niż założyli przy pierwszym spojrzeniu na interfejs.

$\mathrm{Na}$ podstawie synchronizacji danych eye tracker i nagrań wypowiedzi użytkowników w programie ELAN 3.7.2 (Auer i współautorzy 2010) możliwe było określenie, w jaki sposób rozpoznali oni, że moduły są ze sobą interaktywnie połączone. Okazało się, że tylko 66\% badanych zorientowało się, że moduły są połączone ze sobą. Wielu z nich (34\%) zrozumiało, jak ta funkcja działa, gdy kliknęli na obiekt na mapie i zauważyli zaznaczoną odpowiednią linię na wykresie osi równoległych. Z kolei 17\% uczestników badania rozpoznało tę funkcję, gdy kliknęli na obszar na mapie i zauważyli wyróżnienie wiersza w obrębie tabeli. Pozostali, którzy poznali tę funkcję (14\%), dowiedzieli się o niej wtedy, gdy kliknęli w linię na wykresie i zobaczyli zaznaczenie odpowiedniego obszaru na mapie (ryc. 5.4). Zatem mapa była bardzo pomocnym modułem do zauważenia kluczowej funkcji opracowania (dla 52\% badanych). 34\% uczestników pracowało w obrębie poszczególnych 
modułów, nie porównując analizowanych obiektów w pozostałych częściach interfejsu. Jako że poznanie połączenia między modułami jest kluczowe dla pracy z narzędziem, za priorytetowe należy uznać takie jego zaprojektowanie, aby umożliwić wszystkim użytkownikom jak najszybsze rozpoznanie tej funkcjonalności.

Określenie sposobu i momentu zauważenia przez użytkowników połączenia modułów umożliwiło również porównanie, czy podział ich uwagi wizualnej na moduły zmienił się po tym spostrzeżeniu. W związku z tym, że każda osoba określiła to połączenie w innym momencie, czas przed i po odkryciu tej możliwości był dla każdego badanego inny. Dlatego znormalizowano te odcinki czasowe. Porównane zostały odsetek długości fiksacji na każdym module i odsetek liczby sakkad między modułami. Okazało się, że podział uwagi na moduły nie zmienił się istotnie po odkryciu przez badanych połączenia między nimi (tab. 5.2). Można mniemać, że jest to spowodowane faktem, że była to swobodna eksploracja niewymagająca pozyskania konkretnej informacji.

Tabela 5.2. Rozkład uwagi wizualnej przed zorientowaniem się przez badanych o połączeniu między modułami i po zorientowaniu się o tym

\begin{tabular}{|l|c|c|c|c|c|c|}
\cline { 2 - 7 } \multicolumn{1}{c|}{} & \multicolumn{3}{c|}{ \% czasu fiksacji } & \multicolumn{3}{c|}{ \% sakkad pomiędzy modułami } \\
\cline { 2 - 7 } \multicolumn{1}{c|}{} & Mapa & $\begin{array}{c}\text { Wykres osi } \\
\text { równoległych }\end{array}$ & Tabela & $\begin{array}{c}\text { mapa } \leftrightarrow \\
\text { tabela }\end{array}$ & $\begin{array}{c}\text { tabela } \leftrightarrow \\
\text { wykres }\end{array}$ & $\begin{array}{c}\text { wykres } \\
\text { mapa }\end{array}$ \\
\hline przed & 45.1 & 32.4 & 22.5 & 22.5 & 39.0 & 38.5 \\
\hline po & 37.2 & 35.4 & 27.3 & 24.3 & 43.7 & 32.1 \\
\hline
\end{tabular}

\subsection{Sposób pozyskiwania informacji z narzędzia cechującego się redundancją danych}

\subsubsection{Podział uwagi na moduty}

Podobnie jak w zadaniu dowolnej eksploracji analizę danych eye tracking rozpoczęto od ogólnej charakterystyki: poprzez porównanie długości fiksacji na każdym module w kolejnych zadaniach.

Analiza czasu fiksacji na poszczególnych modułach wykazała, że w trakcie rozwiązywania każdego zadania badani patrzyli na wszystkie moduły (tab. 5.3). Badani najdłużej koncentrowali wzrok na module z tabelą. Wpływ rodzaju zadania na długość fiksacji był również istotny 
Tabela 5.3. Średni czas fiksacji na modułach w poszczególnych zadaniach

\begin{tabular}{|c|c|c|c|c|}
\hline & Mapa & $\begin{array}{l}\text { Wykres osi } \\
\text { równoległych }\end{array}$ & Tabela & Ogółem \\
\hline & 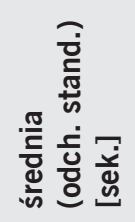 & 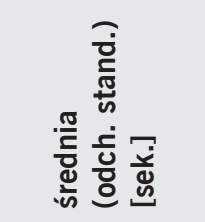 & 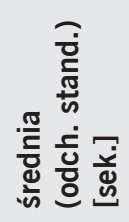 & 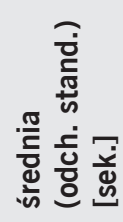 \\
\hline 1: Odczytaj wartości & $\begin{array}{c}8.99 \\
(9.78) \\
\end{array}$ & $\begin{array}{c}11.20 \\
(12.15)\end{array}$ & $\begin{array}{c}17.47 \\
(16.33)\end{array}$ & $\begin{array}{c}12.51 \\
(13.39)\end{array}$ \\
\hline 2: Filtruj & $\begin{array}{c}1.88 \\
(6.76)\end{array}$ & $\begin{array}{c}1.98 \\
(3.69) \\
\end{array}$ & $\begin{array}{l}25.76 \\
(20.05)\end{array}$ & $\begin{array}{c}9.88 \\
(16.67)\end{array}$ \\
\hline $\begin{array}{l}\text { 3: Scharakteryzuj } \\
\text { zróżnicowanie wartości }\end{array}$ & $\begin{array}{c}12.34 \\
(13.74)\end{array}$ & $\begin{array}{c}10.40 \\
(13.55)\end{array}$ & $\begin{array}{l}33.23 \\
(23.53)\end{array}$ & $\begin{array}{c}17.83 \\
(20.36)\end{array}$ \\
\hline 4: Określ relacje & $\begin{array}{c}6.31 \\
(8.71) \\
\end{array}$ & $\begin{array}{c}19.87 \\
(19.30) \\
\end{array}$ & $\begin{array}{l}27.33 \\
(24.40) \\
\end{array}$ & $\begin{array}{c}18.65 \\
(20.24) \\
\end{array}$ \\
\hline 5: Znajdź anomalie & $\begin{array}{c}7.92 \\
(12.09)\end{array}$ & $\begin{array}{l}38.45 \\
(21.72)\end{array}$ & $\begin{array}{l}31.26 \\
(38.01)\end{array}$ & $\begin{array}{l}25.87 \\
(29.04)\end{array}$ \\
\hline Ogółem & $\begin{array}{c}7.46 \\
(10.91)\end{array}$ & $\begin{array}{c}16.38 \\
(19.65)\end{array}$ & $\begin{array}{c}27.00 \\
(25.76)\end{array}$ & $\begin{array}{c}16.95 \\
(21.25)\end{array}$ \\
\hline
\end{tabular}

statystycznie ( $F=9.992, p=0.001)$ : czas fiksacji był najdłuższy dla zadania 5: Znajdź anomalie (średnia 25.87 sekundy), a najkrótszy dla 2: Filtrowanie (średnia długość fiksacji 9.88 sekundy). Ponadto wykazano efekt interakcji obu zmiennych: formy prezentacji oraz rodzaju zadania ( $F=36.221, p=0.001)$, czyli wpływ formy prezentacji na długość fiksacji różnił się istotnie pomiędzy zadaniami.

Wizualizacje długości fiksacji wszystkich uczestników badania w postaci map cieplnych (heat map) dla poszczególnych zadań potwierdzają, że miejsca koncentracji wzroku znacząco różnią się pomiędzy zadaniami (ryc. 5.5).

W trakcie rozwiązywania zadania pierwszego (ryc. 5.5 A) badani, poszukując wartości konkretnego indeksu dla gminy wskazanej w pytaniu, korzystali ze wszystkich modułów. Podwyższone wartości długości fiksacji widoczne są w środkowej części mapy, gdzie był wyświetlany obszar interesujący badanych. W obrębie tabeli widać dłuższe fiksacje na pierwszej kolumnie z nazwami gmin, w miejscu wyszukiwarki gmin według wpisanej nazwy oraz na nazwach kolumn z opisanymi indeksami. Również obszary w obrębie wykresu osi równoległych, gdzie znajdują się opisy indeksów, cechowały się wyraźnie dłuższymi fiksacjami. 
(A) 1: Odczytaj wartości

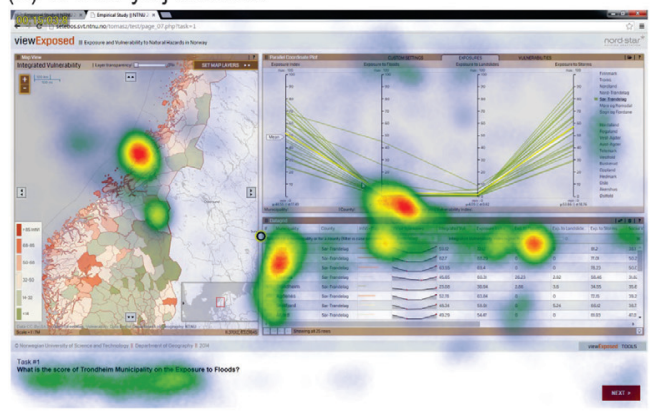

(C) 3: Scharakteryzuj zróżnicowanie wartości

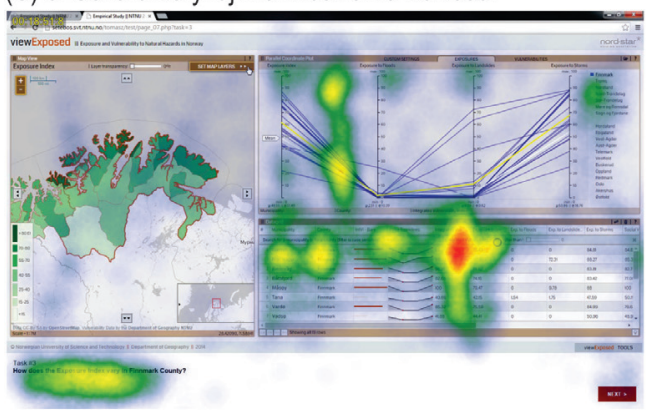

(B) 2: Filtruj

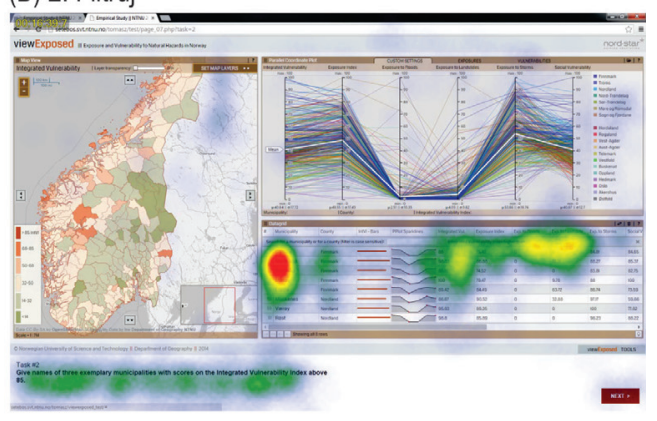

(D) 4: Określ relacje

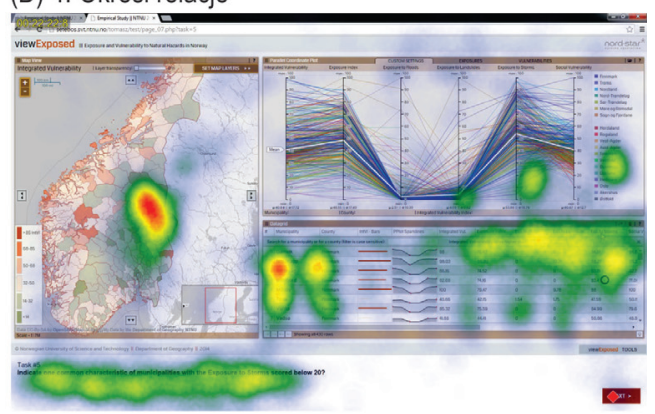

(E) 5: Znajdź anomalie

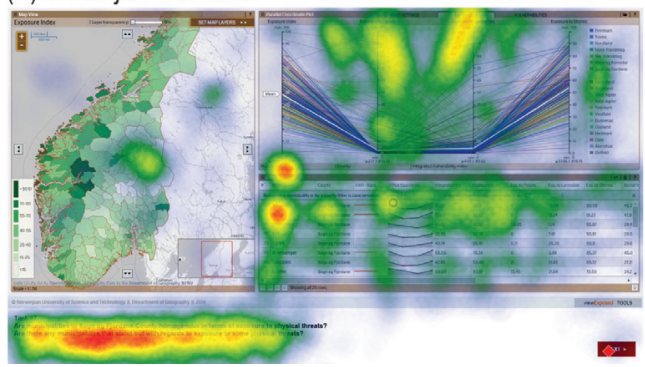

Rycina 5.5. Różne miejsca koncentracji wzroku przez wszystkich badanych w zależności od rodzaju rozwiązywanego zadania

W zadaniu drugim (ryc. 5.5 B), polegającym na selekcji obiektów według wskazanego kryterium, mamy najmniejszy powierzchniowo obszar podwyższonych długości fiksacji. Ograniczał się on w zasadzie do modułu tabeli. Ponownie było to miejsce, gdzie znajduje się pierwsza kolumna z nazwami gmin oraz suwak, który umożliwia wyświetlanie gmin powyżej wskazanej wartości zintegrowanego indeksu podatności.

W zadaniu trzecim (ryc. 5.5 C), wymagającym określenia zróżnicowania wartości, badani poszukiwali tych wartości przede wszystkim za 
pomocą wykresu i tabeli, rzadko patrząc na mapę. Podwyższone wartości długości fiksacji są zatem widoczne na wykresie wzdłuż osi prezentującej wartości wskazanego w pytaniu indeksu oraz w tabeli wzdłuż kolumny, w której znajdują się konkretne wartości tego indeksu w każdej gminie.

Do określenia relacji w zadaniu czwartym (ryc. 5.5 D) badani posłużyli się przede wszystkim mapą i tabelą. Podwyższona długość fiksacji na środkowym obszarze na mapie pokazuje, że badani najczęściej przesuwali zasięg mapy tak, by interesujący ich obszar znajdował się na środku prezentowanego terenu. Z kolei w tabeli badani szczególnie długo koncentrowali wzrok na nagłówkach kolumn z opisami indeksów oraz - tradycyjnie - na kolumnie z nazwami gmin.

Ostatnie zadanie (ryc. 5.5 E) wymagało od badanych wnikliwego czytania polecenia, gdyż najdłuższe fiksacje przypadały właśnie na treść polecenia. Anomalii we wskazanym powiecie badani szukali przede wszystkim za pomocą tabeli i wykresu. Koncentrowali wzrok wzdłuż kolejnych osi na wykresie oraz wzdłuż kolejnych kolumn w tabeli. Widoczne jest zatem, że działali zgodnie z poleceniami oraz poprawnie odnajdywali i wykorzystywali narzędzia do tego przeznaczone.

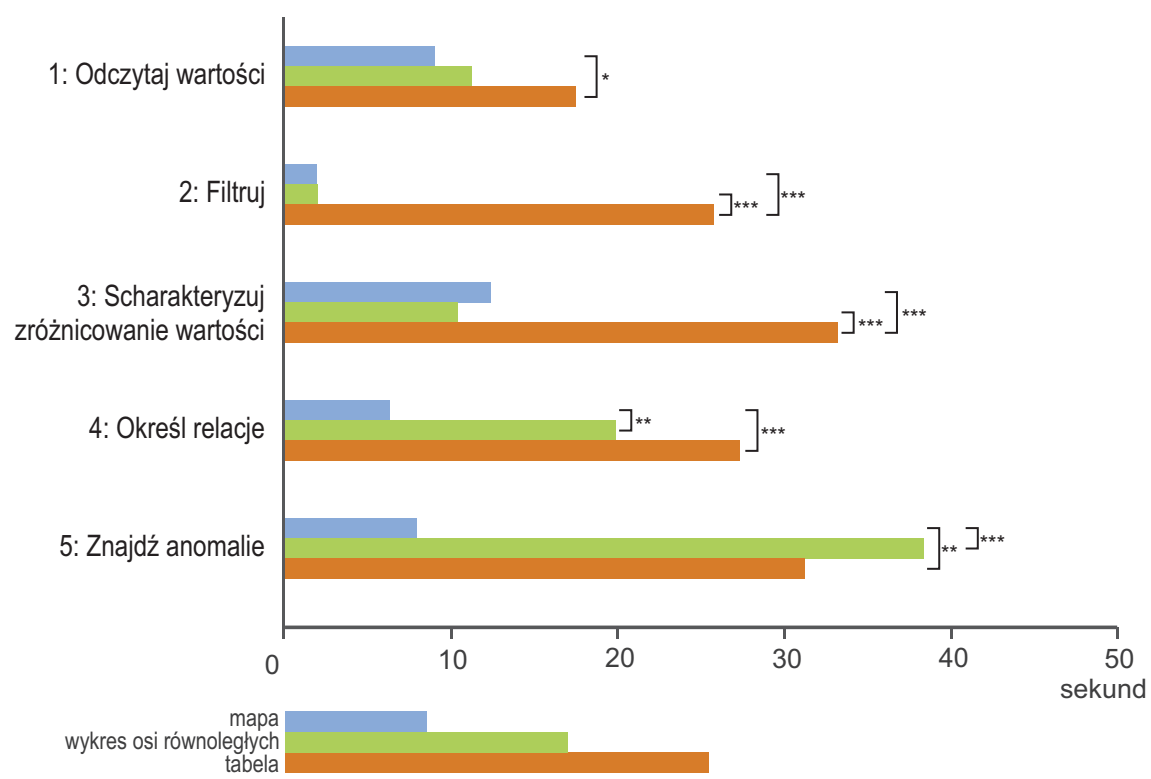

Rycina 5.6. Różnice w długości fiksacji na poszczególne moduły w kolejnych zadaniach

Liczba gwiazdek oznacza różnice istotne statystycznie na poziomie: * $p \leq 0.05$, ** oznacza $p \leq 0.01,{ }^{* * *}$ oznacza $p \leq 0.001$ 
Opisane powyżej różnice $w$ długości fiksacji pomiędzy modułami zostały następnie zweryfikowane za pomocą jednoczynnikowej analizy wariancji ANOVA z testem post-hoc Bonferroniego (ryc. 5.6). Analiza wykazała, że w zadaniu 1 (odczytaj wartości) użytkownicy patrzyli na tabelę istotnie dłużej niż na mapę ( $F=3.383, p=0.041)$, z kolei w zadaniu 2 (filtruj) tabela była oglądana dłużej niż mapa $(F=35.682$, $p=0.001)$ i wykres osi równoległych $(p=0.001)$. Badani, rozwiązując zadanie 3 (scharakteryzuj zróżnicowanie wartości), patrzyli najdłużej na tabelę, dłużej niż na mapę ( $F=15.059, p=0.001)$ i na wykres $(p=0.001$ ). W zadaniu 4 (określ relacje) mapa była oglądana istotnie krócej niż wykres $(F=9.513, p=0.020)$ i tabela $(p=0.001)$. Z kolei $w$ trakcie rozwiązywania zadania 5 (znajdź anomalie) mapa była oglądana krócej niż wykres $(F=10.742, p=0.001)$ i tabela $(p=0.003)$.

\subsubsection{Strategie rozwiązywania zadania}

Analiza sekwencji fiksacji

Podobnie jak w przypadku swobodnej eksploracji dokonano analizy, jak uwaga użytkowników zmieniała się w czasie. Jako że ta część badania wymagała udzielenia odpowiedzi, postanowiono sprawdzić, czy można wyróżnić strategie rozwiązywania zadania. Do tego wykorzystano analizę dopasowania sekwencji (ang. sequence alignment analysis). Metoda ta służy do wyróżniania podobnych sekwencji elementów analizowanych zjawisk. Podobieństwo sekwencji określane jest na podstawie liczby poszczególnych grup elementów, ich położenia w całej sekwencji oraz kolejności ich występowania (Wilson 2008). Metoda ta została zaczerpnięta z bioinformatyki, w której była stosowana do porównywania sekwencji DNA i białek (Wilson, Harvey i Thompson 1999). Stosowana jest również do analizy zjawisk różnego typu, w tym do badań z zakresu kartografii i geowizualizacji (Shoval i Isaacson 2007; Gołębiowska 2015), a także do analizy danych eye tracking (Fabrikant i współautorzy 2008; Opach, Gołębiowska i Fabrikant 2014).

Analiza odbywa się w kolejnych krokach (Wilson, Harvey i Thompson 1999). Najpierw przeprowadzana jest analiza sekwencji parami: każda sekwencja elementów jest porównywana ze wszystkimi pozostałymi w zestawie danych. Przykładowo porównując dwa wyrazy "geografia" oraz „kartografia” w tabeli, oznacza się każde zgodne pary liter z obu wyrazów (ryc. 5.7 A).

Algorytm porównania służy do obliczenia stopnia podobieństwa, zaczynając od górnego lewego narożnika tabeli i postępując ku prawemu 


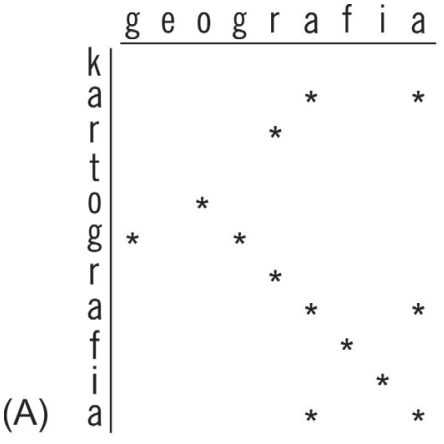

(B)

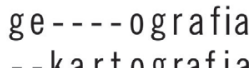

Rycina 5.7. Etapy analizy zgodności: (A) tabela porównania wyrazów „geografia” oraz „kartografia”; (B) wynik analizy dopasowania z wprowadzonymi przerwami między literami (na podstawie C. Wilson, A. Harvey i J. Thompson 1999)

dolnemu. Wynik obliczonego podobieństwa zależy od położenia podobnych elementów na tej ścieżce. Aby umożliwić porównanie takich samych elementów, wstawiana jest przerwa między nimi (ryc. 5.7 B).

Analizie poddano sekwencje fiksacji na poszczególne AOI (mapa, tabela, wykres oraz zadanie) w trakcie rozwiązywania poszczególnych zadań przez każdego badanego. Następnie za pomocą programu Clustal G porównano podobieństwo sekwencji w każdym pytaniu. Kolejność poszczególnych zestawów fiksacji jest związana ze stopniem podobieństwa sekwencji. Analiza pokazała, że przyjęte strategie rozwiązywania zadań różnią się w zależności od rodzaju zadania (ryc. 5.8). Jedyną wspólną cechą sekwencji fiksacji we wszystkich zadaniach jest koncentrowanie wzroku na treści polecenia w początkowym etapie jego rozwiązywania (oznaczone szarym prostokątem i opisane jako TP - treść pytania). Przy rozwiązywaniu wszystkich zadań, poza zadaniem 2, można wyróżnić trzy grupy użytkowników: z przewagą fiksacji na mapie (oznaczeni na ryc. 5.8 jako PM - Przewaga na Mapie), na tabeli (PT) oraz na wykresie (PW). Co istotne, przynależność do grupy PM, PT lub PW zmieniała się u wszystkich badanych (poza jedną osobą) w zależności od rozwiązywanego zadania, co wynikało z elastycznego wykorzystywania modułów.

\section{Potwierdzenie wyników analizy zgodności sekwencji}

Istotnym ograniczeniem analizy zgodności sekwencji jest brak uwzględniania czasu trwania poszczególnych fiksacji. Zatem zarówno krótkie spojrzenie, jak i długie wpatrywanie się w dane miejsce jest traktowane jednakowo. W celu potwierdzenia, czy grupy badanych wyróżnione w poprzedniej analizie różnią się strategią również po uwzględnieniu czasu 
(A) 1: Odczytaj wartości

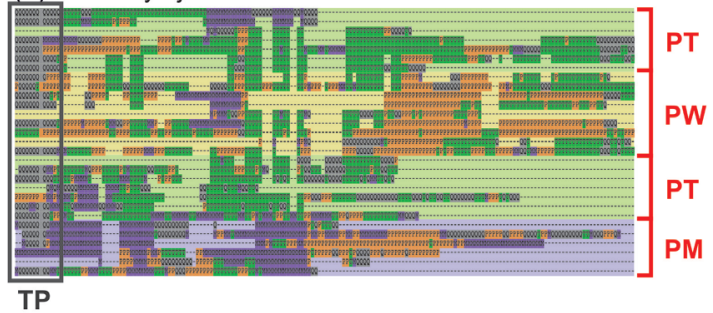

Fiksacja na:

뜰 mapę

瞄 wykres osi równoległych

in tabelę

뽀⿳亠口口 treść polecenia

Użytkownicy

z przewagą fiksacji na:

mapie [PM]

wykresie [PW]

(B) 2: Filtruj

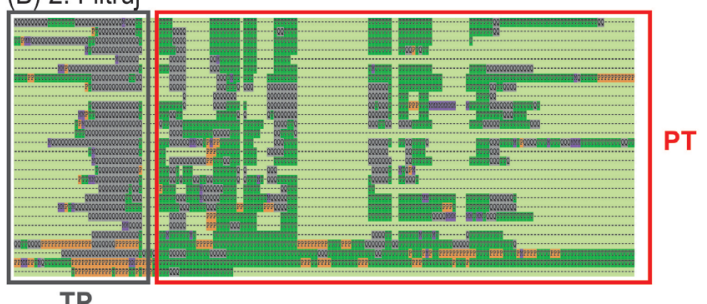

tabeli [PT]

(C) 3: Scharakteryzuj zróżnicowanie wartości

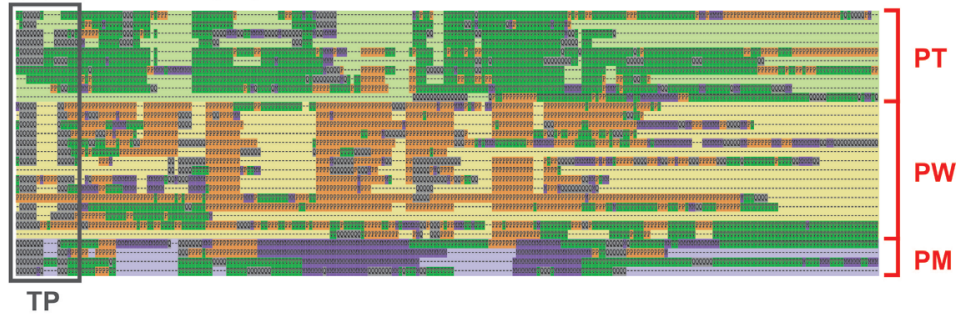

(D) 4: Określ relacje

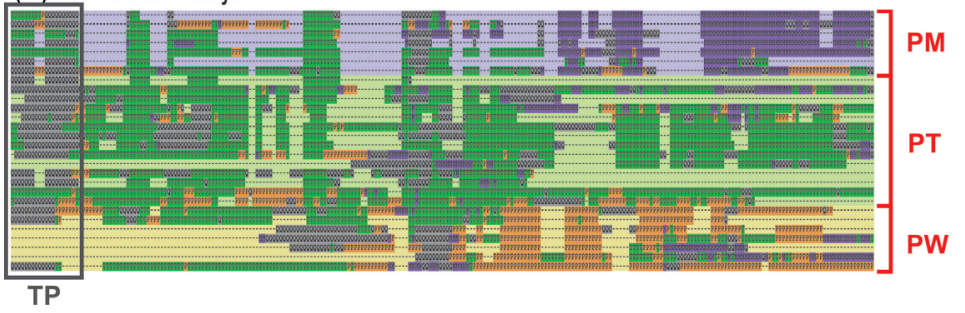

(E) 5: Znajdź anomalie

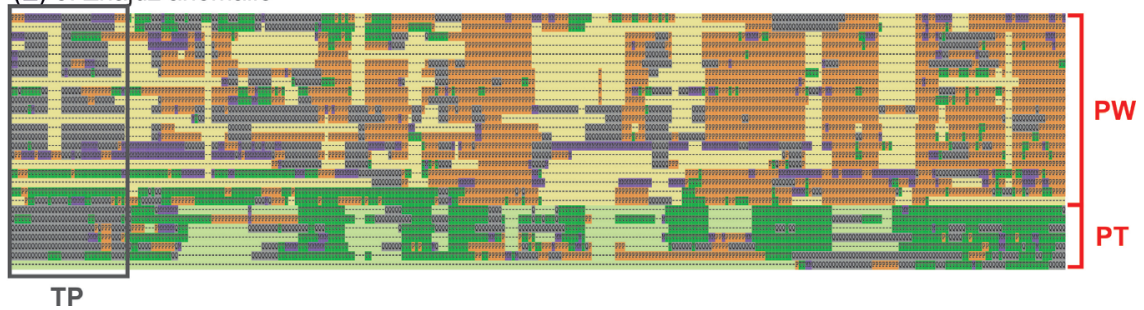

Rycina 5.8. Wyniki analizy dopasowania sekwencji fiksacji z grupami użytkowników wyróżnionymi na podstawie podobieństwa. Jeden wiersz to ciąg fiksacji jednej osoby badanej 


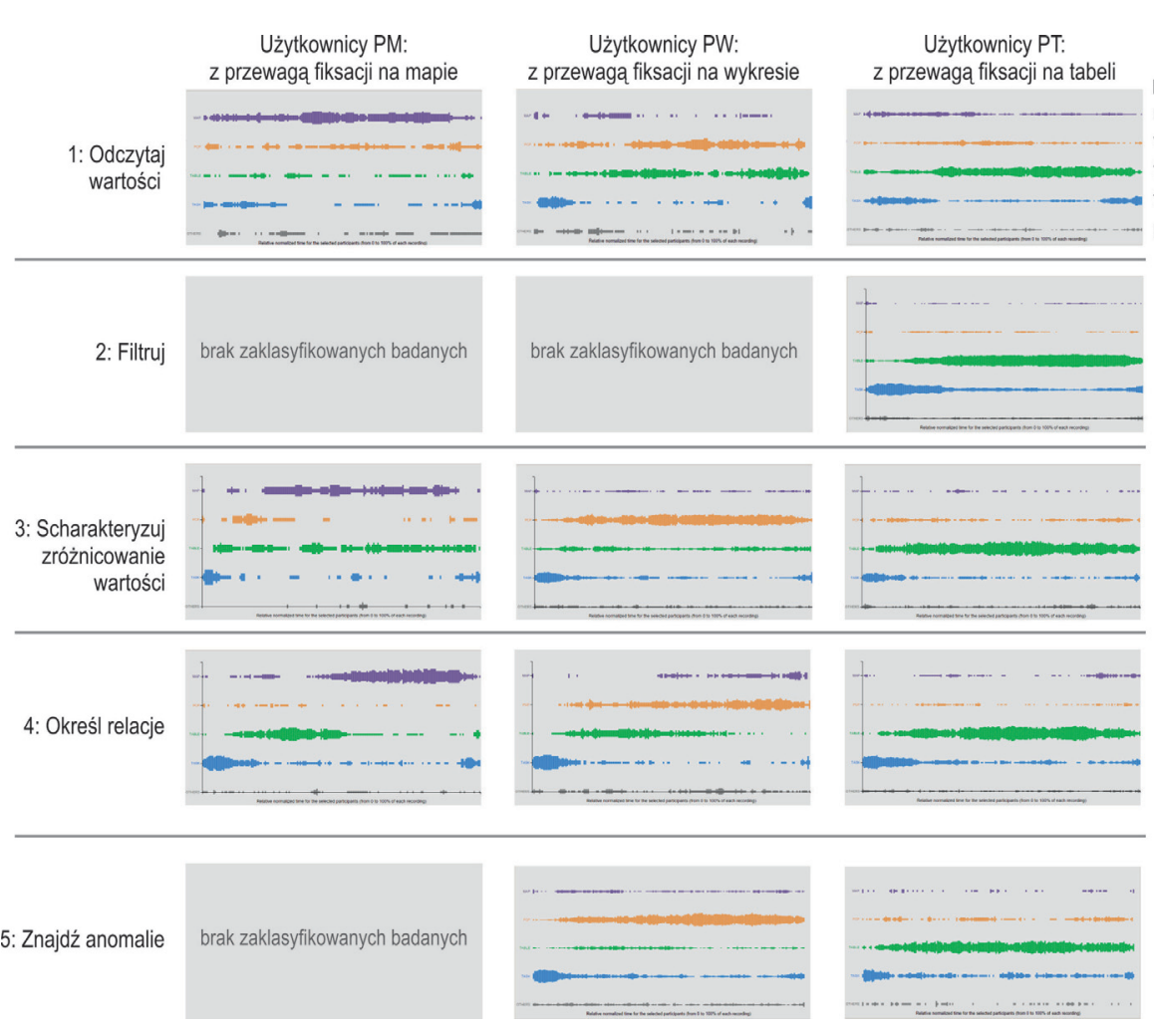

Rycina 5.9. Fiksacje na poszczególne moduły w trakcie rozwiązywania zadań różnych grup użytkowników wyróżnionych na podstawie analizy zgodności sekwencji. Im grubsza barwna linia, tym więcej badanych na danym etapie rozwiązywania zadania patrzyło na wskazany moduł

trwania fiksacji, przeprowadzono dodatkową analizę realizacji zadania. Do jej przeprowadzenia wykorzystano pomiary miejsc patrzenia (POR) na wyróżnionych modułach. W celu uniknięcia wpływu różnic długości realizacji całego zadania przez poszczególnych uczestników dane te zestandaryzowano. W rezultacie na podstawie przeprowadzonej $\mathrm{W}$ ten sposób analizy można stwierdzić, które moduły były oglądane na początku, a które na końcu. Analizy zostały przeprowadzone przy pomocy aplikacji EMAAT. Aplikacja została opracowana w technologii JavaScript i HTML5. Prezentowane są sumarycznie dane wskazanych badanych z podziałem na określone obszary AOI (trzy moduły i treści polecenia) wzdłuż osi czasu. Analiza za pomocą narzędzia EMAAT, przy uwzględnieniu długości trwania fiksacji, potwierdziła wyniki analizy zgodności sekwencji (ryc. 5.9).

Analiza ta pozwala dodatkowo zauważyć jeszcze jedną prawidłowość trudną do uchwycenia podczas poprzednich analiz: osoby zaklasyfikowane 
jako PT (z przewagą fiksacji na tabeli) koncentrowały się głównie na tabeli, udział zaś fiksacji na inne moduły był znikomy (ryc. 5.9 prawa kolumna). Z kolei osoby zaklasyfikowane jako PW (z przewagą fiksacji na wykresie) przenosiły często wzrok również na tabelę (ryc. 5.9 środkowa kolumna), a osoby PM (z przewagą fiksacji na mapie) często koncentrowały wzrok na obu pozostałych modułach (ryc. 5.9 lewa kolumna). Ponadto osoby PM koncentrowały uwagę na mapie dopiero w dalszej części rozwiązywania zadania (treść polecenia była odczytywana na początku i na końcu rozwiązywania zadania). Ta prawidłowość dotyczy sposobu rozwiązywania wszystkich zadań przez wszystkie grupy użytkowników (PM, PT, PW). Wynika to zapewne z faktu, że o ile naturalne jest odczytanie polecenia na początku, o tyle w końcowej fazie zadania, przed podaniem odpowiedzi, badani utwierdzali się i sprawdzali, czy odnoszą się odpowiednio w swojej odpowiedzi do treści polecenia.

\subsubsection{Kluczowe etapy rozwiązywania zadania}

Kolejna analiza odnosi się do dwóch podstawowych etapów rozwiązywania zadania: określenia warunków, według których poszukuje się odpowiedzi, oraz jego rozwiązania (Andrienko i Andrienko 2006a). Tym samym wskazano, jaki był powód koncentracji wzroku na konkretnym module. Każde zadanie zostało podzielone na dwa kluczowe etapy:

1) selekcja: wybranie obiektów, które spełniają kryteria wymienione w pytaniu, np. w zadaniu 1: „Jaka jest wartość indeksu ekspozycji na powodzie w gminie Trondheim?". Jest to wybór gminy Trondheim; 2) odczyt informacji: jest to odczytanie informacji, która stanowi odpowiedź na pytanie, w przypadku zadania 1 jest to wartość: 2.86 .

Dzięki temu, że wieloelementowa geowizualizacja złożona jest z modułów połączonych ze sobą, możliwa jest realizacja tych dwóch etapów przy pomocy różnych modułów, czyli różnych form prezentacji. W celu identyfikacji tych dwóch etapów, w trakcie rozwiązywania zadań przez każdego badanego, wykorzystano animowane nagrania fiksacji i sakkad oraz nagrania ekranu, na których widoczna jest interakcja z narzędziem. Dane te zostały zsynchronizowane z nagraniami odpowiedzi udzielanych przez badanych. Dzięki tej analizie określono, za pomocą którego modułu badani realizowali każdy z etapów rozwiązywania zadania (ryc. 5.10): selekcja na podstawie kryteriów określonych w poleceniu oraz odczyt informacji - czyli odpowiedzi na zadane pytanie. Podejście to wzbogaca poprzednie analizy, nie zawsze bowiem element, który przez dłuższy czas ogląda badany, jest rzeczywiście przydatny. Może to oznaczać coś 


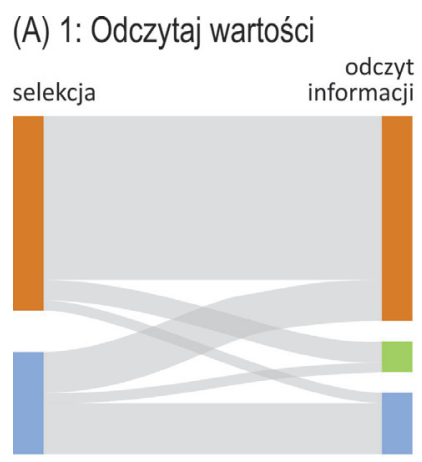

(D) 4: Określ relacje

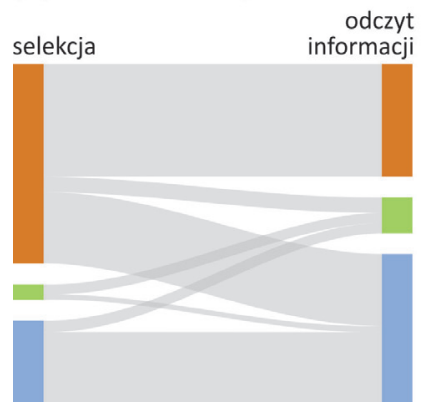

(B) 2: Filtruj

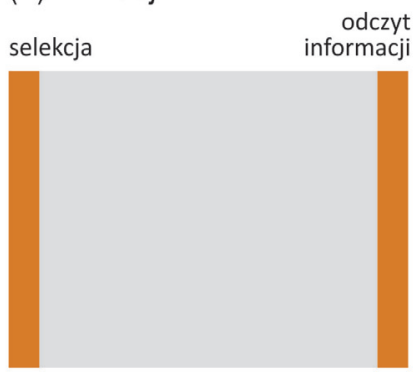

(E) 5: Znajdź anomalie

(C) 3: Scharakteryzuj zróżnicowanie wartości odczyt selekcja informacji
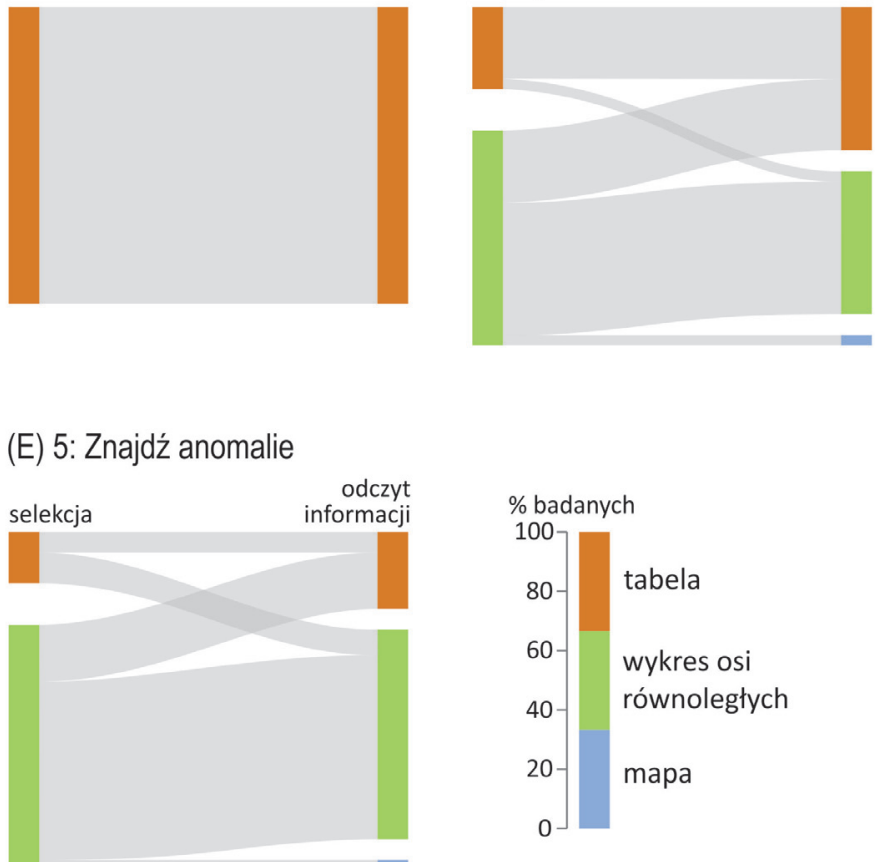

Rycina 5.10. Moduły wykorzystane do realizacji kluczowych etapów rozwiązywania zadania

wręcz przeciwnego: że informacja w tym miejscu jest trudna do uzyskania, zatem potrzeba większego wysiłku i dłuższego czasu, by uzyskać poszukiwaną informację (Jacob i Karn 2003).

Okazało się, że w trakcie rozwiązywania prawie wszystkich zadań użytkownicy korzystali z kilku modułów. Jedynie dla zadania 2 zrealizowano kluczowe etapy rozwiązywania zadania przy pomocy jednego modułu - tabeli (ryc. 5.10 B), co potwierdzają wyniki dwóch poprzednich analiz (opisanych w podrozdziałach 5.2.1 oraz 5.2.2). W zadaniu pierwszym (ryc. $5.10 \mathrm{~A}$ ) większość badanych wyselekcjonowała gminy przy użyciu tabeli. Większa ich część odczytała również potrzebne informacje $z$ tego modułu. Pozostali badani dokonali selekcji obiektów przy pomocy mapy, a odpowiedzi udzielili na podstawie tego samego modułu lub tabeli i wykresu. Z kolei w trakcie rozwiązywania zadania 3 (ryc. $5.10 \mathrm{C}$ ) wykres osi równoległych i tabela okazały się pomocne: zarówno do selekcji obiektów, jak i odnalezienia odpowiedzi. W zadaniu 4 (ryc. 5.10 D) zrealizowano kluczowe etapy w najbardziej zróżnicowany 
sposób: zarówno selekcja, jak i udzielenie odpowiedzi były przeprowadzone na podstawie wszystkich trzech modułów. Tabela okazała się pomocna dla większości badanych na pierwszym etapie, mapa zaś - na drugim etapie rozwiązywania zadania. Ostatnie zadanie 5 (ryc. 5.10 E) zostało zrealizowane przez większość badanych za pomocą wykresu, większość osób użyło tego modułu zarówno do selekcji, jak i odczytu informacji.

\subsubsection{Poprawność odpowiedzi}

Większość udzielonych odpowiedzi była poprawna, jednak nie było ani jednej osoby, która poprawnie odpowiedziała na wszystkie pięć pytań. Na rycinie 5.11 pokazano odsetek poprawnych odpowiedzi na kolejne pytania: zadanie 1 zostało poprawnie rozwiązane przez największą liczbę badanych, z kolei zadanie 3 cechowało się najniższym udziałem poprawnych odpowiedzi (na poziomie 65\%).

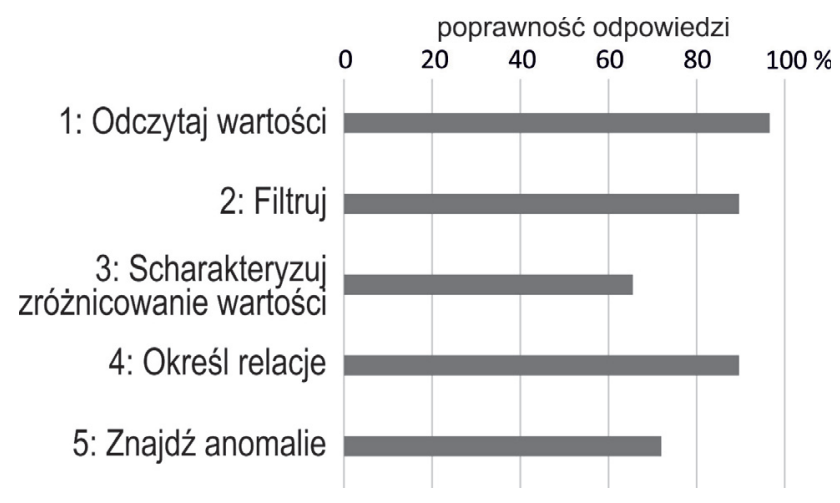

Rycina 5.11. Odsetek poprawnych odpowiedzi na poszczególne pytania

Dzięki zastosowaniu różnych metod zbierania danych możliwe było wskazanie przyczyny błędnych odpowiedzi. Na podstawie nagrań ekranu zsynchronizowanych z danymi eye tracking wyróżniono przyczyny błędów, które pogrupowano na kilka kategorii (rycina 5.12).

Błędy były $w$ większości spowodowane odwoływaniem się do niewłaściwego atrybutu (nie tego indeksu, o którym była mowa w pytaniu). Inne błędy wynikały z odniesienia się do niewłaściwego obiektu, braku analizowania wszystkich wymaganych obiektów lub niepoprawnego porządkowania danych. Większość błędnie udzielonych odpowiedzi dotyczyło informacji odczytanych z tabeli (ryc. 5.13). Takie błędy pojawiały się w trakcie odpowiedzi na każde zadane pytanie. Ponadto każde wskazane 


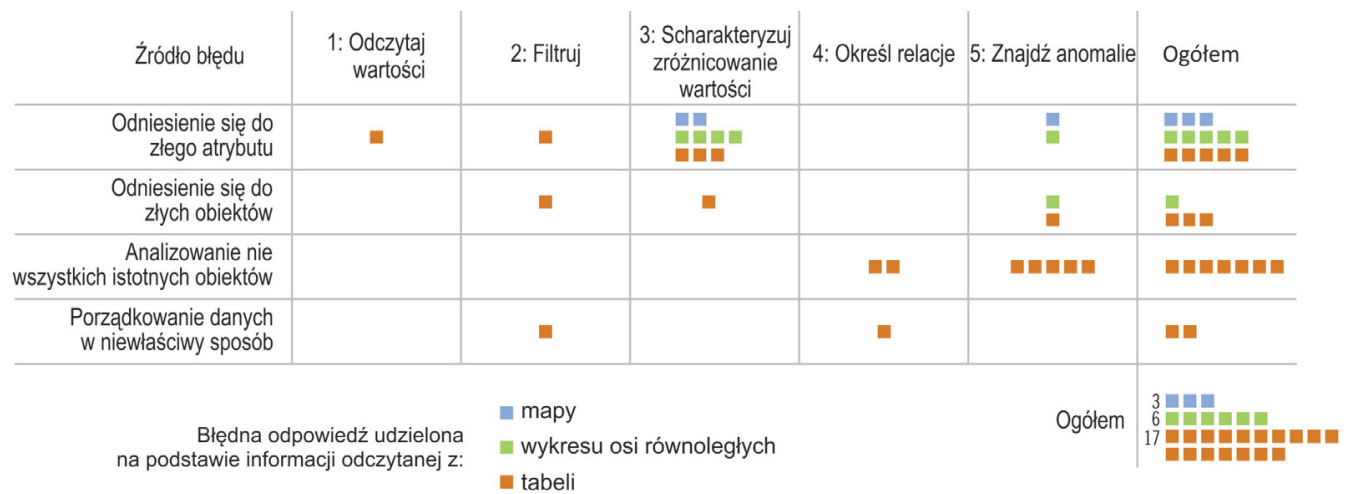

Rycina 5.12. Liczba błędów i ich przyczyny w poszczególnych zadaniach

(A) 1: Odczytaj wartości

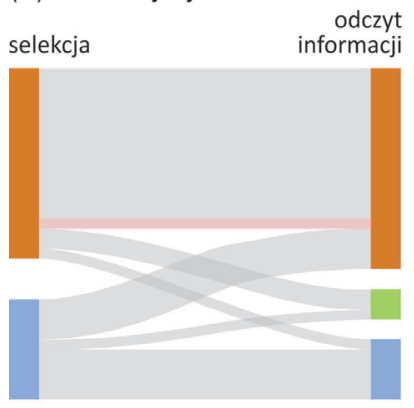

(D) 4: Określ relacje

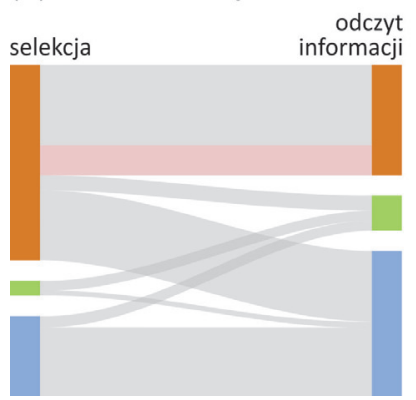

(B) 2: Filtruj

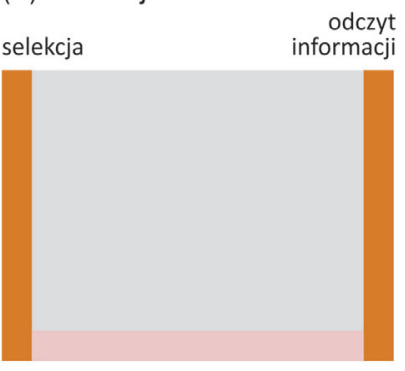

(E) 5: Znajdź anomalie

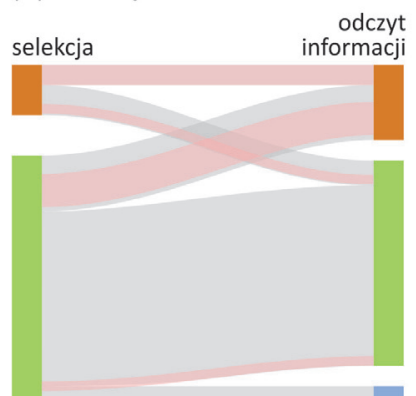

(C) 3: Scharakteryzuj zróżnicowanie
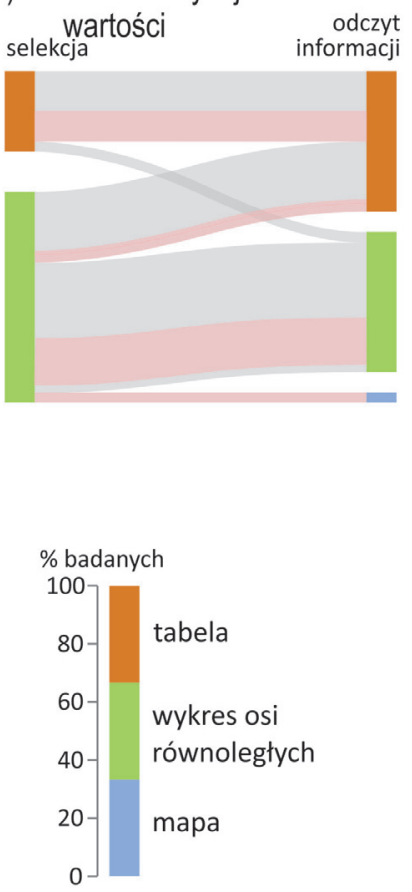

Rycina 5.13. Moduły wykorzystane do kluczowych etapów rozwiązywania zadań poprawnych (zaznaczonych na szaro) oraz błędnych (zaznaczonych na czerwono) 
na ryc. 5.12 źródło błędów pojawiało się w odpowiedziach udzielonych na podstawie tabeli.

Zestawienie błędnych odpowiedzi z modułami, na podstawie których zrealizowano dwa kluczowe etapy rozwiązywania zadania (omówione w podrozdziale 5.2.3), pokazuje inne właściwości błędnych odpowiedzi (ryc. 5.13). Okazało się, że 65\% niepoprawnych odpowiedzi udzielono, gdy użytkownicy korzystali z tego samego modułu do obu kluczowych etapów rozwiązywania zadania. Były to przede wszystkim tabela oraz wykres osi równoległych. Moduł tabeli okazał się być wyjątkowo problematycznym, pomimo że umożliwia wgląd do danych surowych. Okazuje się zatem, że brak uprzystępnienia za pomocą grafiki może okazać się kłopotliwy, a nawet mylący. 


\section{Dyskusja wyników}

\subsection{Sposób pracy z nieznanym wieloelementowym narzędziem geowizualizacji}

Badanie i analiza pierwszego kontaktu użytkowników z wieloelementową geowizualizacją pozwoliły na sfomułowanie wniosków na temat sposobu zapoznawania się z nieznanym narzędziem geowizualizacji w czasie swobodnej pracy. Geowizualizacje wieloelementowe stanowią duży potencjał dla efektywnej eksploracji dużych i złożonych zestawów danych, jednak wskazywany jest problem ich ograniczonego zastosowania. Zatem zrozumienie, w jaki sposób użytkownicy uczą się tego typu opracowań i jak można im w tym pomóc, wydaje się kluczowe dla spopularyzowania wieloelementowych geowizualizacji.

Następne podrozdziały odnoszą się do kolejnych pytań badawczych 1a-1c sformułowanych w rozdziale 4 , czyli:

1.a. Które funkcje oraz elementy interfejsu są pomocne w nauce nieznanego wieloelementowego narzędzia geowizualizacji?

1.b. Na których elementach interfejsu geowizualizacji wieloelementowej użytkownicy koncentrują się $w$ trakcie poznawania nieznanego wcześniej narzędzia?

1.c. Które funkcje interaktywne są przez użytkowników chętnie wykorzystywane $\mathrm{w}$ celu zrozumienia, jak działa wieloelementowe narzędzie geowizualizacji?

Zostaną następnie podsumowane przez zestaw wskazówek, które mogą być pomocne dla osób, które projektują materiały szkoleniowe dla użytkowników rozpoczynających pracę z wieloelementowym narzędziem geowizualizacji. 


\subsubsection{Elementy pomocne $w$ nauce nieznanego wieloelementowego narzędzia geowizualizacji}

Przeprowadzone badanie wykazało, że przy pierwszym kontakcie z wieloelementowym narzędziem geowizualizacji użytkownicy są zdezorientowani, co potwierdza wnioski z innych badań (Baldonado, Woodruff i Kuchinsky 2000). Badani wskazywali, że dezorientujące jest pojawienie się wielu elementów jednocześnie, a interfejs cechuje się dużą złożonością. Wyraźne wskazówki, w jaki sposób rozpocząć pracę i jak zacząć interakcje, zwłaszcza mające na celu filtrowanie lub wyróżnienie wybranych elementów, wydają się kluczowe. Zatem w pierwszej kolejności powinno się wyraźnie wskazać interaktywne połączenie między modułami, zwłaszcza że w trakcie swobodnej eksploracji nie wszyscy użytkownicy zorientowali się, jaki jest sposób działania narzędzia. Połączenie interaktywne powoduje filtrowanie informacji i wyróżnienie wybranych elementów, a zatem znacznie redukuje złożoność obrazu oraz daje wyraźną wskazówkę, na których elementach interfejsu należy koncentrować uwagę (Roberts 2007). Kiedy tylko użytkownicy zorientowali się, jak działa połączenie między modułami, korzystanie z narzędzia stało się dla nich znacznie łatwiejsze, a samo opracowanie - bardziej przystępne.

Ponadto podczas pierwszego kontaktu z nieznanym narzędziem badani intuicyjnie kierowali uwagę na wszystkie elementy wyjaśniające: legendę, panel informacyjny, nagłówki kolumn w tabeli, opisy osi wykresu oraz opisy zakładek przy wykresie, najczęściej - jak już zaznaczono - rezygnując z samouczka dostępnego pod opisanym klawiszem. Potwierdza to opinie, że użytkownicy nie chcą czytać instrukcji (Plaisant 2005), lecz chcą uczyć się w trakcie pracy z narzędziem. Z tego powodu wszystkie elementy wyjaśniające powinny być dobrze widoczne i możliwie jak najbardziej informacyjne. Również C. Zuo, L. Ding i L. Meng (2020) po przeprowadzeniu empirycznej ewaluacji narzędzia wieloelementowego zwracali uwagę na duże znaczenie wyraźnych i zrozumiałych napisów.

Pomimo że badani w trakcie zadania dowolnej eksploracji nie mieli do wykonania żadnego zadania, to ich sposób eksploracji odzwierciedlał proces opisany w koncepcji Information Seeking Mantra autorstwa B. Shneidermana (1996), co jest uważane za odzwierciedlenie sposobu eksploracji danych (Andrienko i Andrienko 2006a). B. Shneiderman (1996) podsumował proces poznawania danych: najpierw ogląd, potem przybliżenie i filtrowanie, następnie szczegóły widoczne na żądanie. W trakcie pierwszego kontaktu (ryc. 5.2) uczestnicy badania najpierw przyglądali się mapie, która umożliwia ogólną prezentację całego obszaru 
i zmienność przestrzenną indeksów. Następnie przenieśli uwagę na wykres osi równoległych, który umożliwiał analizę wartości różnych indeksów na wybranym obszarze. Z kolei tabela, oglądana przez badanych w dalszych etapach, umożliwiła uzyskanie szczegółowych danych o interesujących ich elementach.

\subsubsection{Elementy przyciągające uwagę $w$ trakcie poznawania wieloelementowego narzędzia geowizualizacji}

Elementy objaśniające to te, na których badani koncentrowali wzrok, np. legenda mapy, opis nagłówków kolumn, opis osi wykresu. Kolejnym elementem przyciągającym uwagę uczestników badania okazała się być ponadto nietypowa forma prezentacji w postaci wykresu osi równoległych. Wyniki badań map potwierdzają, że nietypowe rozwiązania przyciągają uwagę (Edsall i Deitrick 2009). Jednak pomimo że uczestnicy badania przyglądali się wykresowi, niechętnie podejmowali się interakcji. Opisywali wykres jako nieklarowny z powodu zbyt dużej liczby linii wyświetlonych jednocześnie. Potwierdza to opinię J. Heinricha i D. Weiskopfa (2013), że unikanie zbytniego zgrupowania wielu elementów w ramach interfejsu jest ważnym czynnikiem w ocenie ich użyteczności. Aspekt ten powinien być uważnie rozważony w przypadku uwzględnienia wykresu osi równoległych do narzędzi geowizualizacji. Sposób na redukcję prezentacji zbyt wielu linii w postaci wyróżnienia konkretnej linii lub wyświetlenia tylko wybranej linii - to jedno z możliwych rozwiązań przyczyniających się do obniżenia złożoności wizualnej tego elementu.

Użytkownicy w dużej mierze uczyli się narzędzia przez czytanie elementów wyjaśniających, jednocześnie nie podejmując interakcji i rezygnując z kliknięcia w jakikolwiek element. $Z$ tego powodu ważne jest umieszczenie czytelnych i informacyjnych elementów wyjaśniających, które jednocześnie będą informowały o oczekiwanym działaniu. Kiedy użytkownicy zaczną używać narzędzia, jest wielce prawdopodobne, że zorientują się $\mathrm{w}$ połączeniach między modułami, co znacznie ułatwi im pracę i obniży postrzeganą złożoność opracowania.

\subsubsection{Chętnie wykorzystywane funkcje interaktywne}

Badani chętnie korzystali z mapy, zapewne dlatego, że jest to znana im forma prezentacji danych. Jak już wspomniano, do zmiany zarówno zasięgu, jak i skali mapy używali myszy, rzadko korzystając z przeznaczonych 
do tego klawiszy. Intuicyjnie bowiem korzystali z funkcji, które są znane z innych popularnych aplikacji mapowych, takich jak GoogleMaps. Płynie $z$ tego wniosek dla projektantów, w jaki sposób zmniejszyć liczbę przycisków w ramach interfejsu: poprzez rezygnację z funkcji realizowanych za pomocą klawiszy na rzecz funkcji realizowanych za pomocą myszy $\mathrm{i}$ jej rolki, podobnie jak w popularnych rozwiązaniach w innych aplikacjach. W ten sposób zaoszczędzone będzie miejsce interfejsu na mniej intuicyjne funkcje. Tabela okazała się najmniej zachęcająca do eksploracji. Co prawda użytkownicy chętnie w nią klikali i przesuwali wiersze, ale jednocześnie była ona najkrócej oglądana.

Badani nieśmiało korzystają z funkcji interaktywnych. Większość z nich skorzystała tylko z trzech funkcji: wyboru obszaru na mapie, wyboru wiersza oraz przesuwania wierszy w tabeli. Swobodna eksploracja funkcji następowała tylko poprzez użycie lewego klawisza myszy. Zatem warto, by kluczowe funkcje były dostępne poprzez naciśnięcie tego klawisza. Dla zaawansowanych użytkowników tylko rzadko przydatne funkcje powinny być dostępne przez naciśnięcie prawego klawisza.

\subsubsection{Wskazówki w trakcie projektowania materiałów szkoleniowych}

Użytkownicy wieloelementowej geowizualizacji potrzebują niewielkiego wprowadzenia, aby przełamać niechęć $w$ trakcie pierwszego kontaktu z tego typu opracowaniem. Dzięki zbadaniu procesu uczenia się nieznanego narzędzia możliwe było wskazanie, co budzi niechęć użytkowników i co jest dla nich problematyczne.

Dzięki wykorzystaniu metody eye tracking, razem z formularzami interakcji oraz protokołami głośnego myślenia, możliwe było prześledzenie procesu poznawania narzędzia wieloelementowego. Te zróżnicowane metody pozwoliły na analizę badanych procesów pod różnym kątem. Badani chętnie oglądali cały interfejs, kluczowe zaś było dla nich poznanie interaktywnego połączenia między modułami. Od tego momentu praca z narzędziem stała się dla nich dużo łatwiejsza. Aby poznać nieznany interfejs, koncentrowali uwage głównie na elementach objaśniających: legendzie, opisach osi i nagłówkach kolumn tabeli. Oglądając interfejs, skupiali uwagę na wszystkich jego modułach, nie pomijając wykresu uznawanego za trudny dla użytkowników. Wręcz przeciwnie, nietypowa metoda wykresu przyciągnęła uwagę użytkowników, którzy często koncentrowali wzrok na tym właśnie module, choć niechętnie podejmowali się interakcji. Zaprojektowany starannie interfejs geowizualizacji, nawet 
Tabela 6.1. Wskazówki dotyczące treści materiałów szkoleniowych przeznaczonych dla początkujących użytkowników geowizualizacji wieloelementowych

\begin{tabular}{|c|c|c|}
\hline Problematyka & Wskazówka & Uzasadnienie \\
\hline \multirow[t]{3}{*}{$\begin{array}{l}\text { Co powinno } \\
\text { być omówione } \\
\text { W pierwszej } \\
\text { kolejności? }\end{array}$} & $\begin{array}{l}\text { Interaktywne połączenie } \\
\text { pomiędzy modułami }\end{array}$ & $\begin{array}{l}\text { Użytkownicy postrzegali narzędzie jako zbyt } \\
\text { złożone tylko do momentu zorientowania } \\
\text { się, w jaki sposób działa połączenie między } \\
\text { modułami }\end{array}$ \\
\hline & $\begin{array}{l}\text { Informacja, od czego rozpocząć } \\
\text { pracę z narzędziem }\end{array}$ & $\begin{array}{l}\text { Badani mówili wprost o potrzebie takiej } \\
\text { wskazówki }\end{array}$ \\
\hline & $\begin{array}{l}\text { Omówienie nietypowych form } \\
\text { wizualizacji, takich jak wykres } \\
\text { osi równoległych }\end{array}$ & $\begin{array}{l}\text { Nietypowa forma przyciągnęła uwagę } \\
\text { badanych, lecz byli niechętni do swobodnego } \\
\text { testowania, jak ona działa. W ten sposób nie } \\
\text { poznali możliwości i zalet tej formy prezentacji } \\
\text { danych }\end{array}$ \\
\hline \multirow[t]{3}{*}{$\begin{array}{l}\text { Jak zredukować } \\
\text { zakres treści } \\
\text { omawianych } \\
\text { w materiałach } \\
\text { szkoleniowych? }\end{array}$} & $\begin{array}{l}\text { Zastosowanie rozwiązania } \\
\text { znanego z innych popularnych } \\
\text { narzędzi }\end{array}$ & $\begin{array}{l}\text { Badani intuicyjnie używali myszy do } \\
\text { zmiany zasięgu i skali mapy, nie korzystając } \\
\text { z przeznaczonych do tego (intuicyjnych) } \\
\text { przycisków }\end{array}$ \\
\hline & $\begin{array}{l}\text { Funkcje interaktywne powinny } \\
\text { być dostępne przez naciskanie } \\
\text { lewego klawisza myszy, wtedy } \\
\text { będą łatwo odnalezione }\end{array}$ & $\begin{array}{l}\text { Badani korzystali tylko z lewego klawisza } \\
\text { myszy, tylko jedna osoba raz skorzystała } \\
\text { z klawisza prawego }\end{array}$ \\
\hline & $\begin{array}{l}\text { Opisy powinny być jak } \\
\text { najbardziej informacyjne } \\
\text { i zachęcające do interakcji } \\
\text { z narzędziem, np. opis „Wybierz } \\
\text { elementy do pokazania w tym } \\
\text { module" }\end{array}$ & $\begin{array}{l}\text { Osoby badane przede wszystkim analizowały } \\
\text { wszystkie elementy wyjaśniające (opisy, } \\
\text { legendy, nazwy kolumn itd.), kiedy pierwszy } \\
\text { raz oglądały nieznane narzędzie }\end{array}$ \\
\hline \multirow[t]{3}{*}{$\begin{array}{l}\text { Jak uczynić } \\
\text { interfejs } \\
\text { narzędzia } \\
\text { bardziej } \\
\text { intuicyjnym? }\end{array}$} & $\begin{array}{l}\text { Zredukowanie nieczytelnej } \\
\text { prezentacji wykresu osi } \\
\text { równoległych w ustawieniach } \\
\text { domyślnych przy wielu liniach } \\
\text { za pomocą wyróżnienia lub } \\
\text { pokazania tylko jednej linii } \\
\text { (zamiast wszystkich linii } \\
\text { jednocześnie) }\end{array}$ & $\begin{array}{l}\text { Badani wprost mówili, że wszystkie } \\
\text { wyświetlone linie bez wyróżnienia żadnego } \\
\text { elementu są nieczytelne i zniechęcające. } \\
\text { Wyróżnienie jednej linii było wskazówką, } \\
\text { w jakiej kolejności studiować ten element } \\
\text { narzędzia }\end{array}$ \\
\hline & $\begin{array}{l}\text { Wszystkie elementy wyjaśniające } \\
\text { powinny być dobrze widoczne } \\
\text { w ustawieniach domyślnych }\end{array}$ & $\begin{array}{l}\text { Tylko kilka osób zauważyło ważny przycisk } \\
\text { służący do zmiany sposobu wyświetlania } \\
\text { mapy, duża część badanych nie była } \\
\text { świadoma tej funkcji }\end{array}$ \\
\hline & $\begin{array}{l}\text { Opisy powinny zachęcać do } \\
\text { działania (np. zaznaczania, } \\
\text { naciskania) }\end{array}$ & $\begin{array}{l}\text { Badani spędzili dość dużo czasu, wyłącznie } \\
\text { oglądając interfejs, nie podejmując żadnych } \\
\text { działań, takich jak zaznaczanie, klikanie }\end{array}$ \\
\hline
\end{tabular}


tak złożony jak narzędzie wieloelementowe, może być więc użyteczny i skutecznie wykorzystany przez użytkowników.

Odpowiedzi na pytania o charakterze eksploracyjnym sformułowane w poprzednich podrozdziałach można zestawić jako wnioski, które mogą być pomocne przy projektowaniu materiałów szkoleniowych dla osób rozpoczynających pracę z tego typu narzędziami geowizualizacji (tab. 6.1).

\subsection{Część testowa}

Część testowa badania miała na celu weryfikację przydatności redundancji w geowizualizacji wieloelementowej. Testowane były hipotezy sformułowane $w$ rozdziale 4 . Wyniki przeprowadzonego badania pozwalają na przyjęcie hipotezy pierwszej:

\section{H1. Użytkownicy w trakcie korzystania z wieloelementowego narzę- dzia geowizualizacji przenoszą swoją uwagę na różne elementy prezentujące te same dane, ale w inny sposób.}

Wieloaspektowa analiza potwierdziła, że badani wykorzystywali wszystkie moduły i formy wizualizacji do większości zadań. Ponadto w ramach jednego zadania różne formy prezentacji były wykorzystywane do różnych celów - kluczowych etapów rozwiązania zadania: selekcji obiektów oraz odczytania informacji. W czterech z pięciu zadań badani użyli innych metod prezentacji realizacji etapów rozwiązywania zadania w ramach jednego pytania. Zatem zmiana kontekstu, o której mówili M.Q.W. Baldonado, A. Woodruff i A. Kuchinsky (2000), nie stanowiła problemu dla badanych. Nie odbiło się to również negatywnie na odpowiedzi. Co więcej, przyjęcie podejścia odwrotnego, realizacji kluczowych etapów zadania za pomocą jednego modułu, często kończyło się udzieleniem błędnych odpowiedzi. 65\% niepoprawnych odpowiedzi dotyczyło sytuacji, gdy użytkownicy korzystali z tego samego modułu do obu kluczowych etapów zadania.

Analiza strategii rozwiązywania zadania na podstawie położenia fiksacji pozwoliła na wyróżnienie trzech kategorii użytkowników: z przewagą fiksacji na mapie, na tabeli oraz na wykresie. Wyróżnienie tych kategorii zostało również potwierdzone $w$ trakcie analizy z uwzględnieniem czasu trwania fiksacji. Takie zróżnicowanie sposobu pracy badanych potwierdza opinię J.C. Robertsa (2008), że użytkownicy mogą uznawać różne metody jako najbardziej korzystne do realizacji tego samego celu. Jest to potwierdzenie zalety wieloelementowej geowizualizacji, która cechuje 
się redundancją danych między modułami, co umożliwia użytkownikom samodzielne podjęcie decyzji, z którego modułu skorzystać.

Co istotne, poszczególne grupy użytkowników, wyróżnione na podstawie przewagi fiksacji na różnych modułach, nie różniły się istotnie pod względem poprawności odpowiedzi. Potwierdza to wnioski R.M. Edsalla (2003), że w przypadku wielu operacji różne formy prezentacji przedstawiające te same dane mogą skutkować podobną poprawnością odpowiedzi. W badaniach R.M. Edsalla (2003) weryfikowano tę kwestię w odniesieniu do dwóch metod: wykresu osi równoległych oraz wykresu punktowego. Niniejsze badania pozwalają rozszerzyć ten wniosek na większą liczbę form prezentacji danych.

Przeprowadzone badanie pozwala również przyjąć drugą postawioną przeze mnie hipotezę:

\section{H2. W zależności od rodzaju zadania użytkownicy odczytują infor- macje $z$ różnych modułów, w których te same dane prezento- wane są za pomocą innej metody.}

Jedynym zadaniem, które było rozwiązane jednolicie za pomocą jednej metody prezentacji, było zadanie filtrowania, które wszyscy badani rozwiązali za pomocą tabeli. Analogiczny typ zadań wykorzystano w badaniach E.L. Koua, A.M. MacEachrena i M.-J. Kraaka (2006), w których porównywano mapę i wykres osi równoległych, wykazano wyższość mapy w tym kontekście. Badani jednak nie mieli możliwości skorzystania $z$ tabeli.

Złożone zadanie piąte, odnoszące się do kilku atrybutów jednocześnie, było rozwiązywane $w$ dużej mierze przy pomocy wykresu osi równoległych. Osoby, które skorzystały z tabeli do rozwiązania tego zadania, udzielały istotnie częściej niepoprawnej odpowiedzi. Potwierdza to opinię R.M. Edsalla (2003), że wykres osi równoległych jest dogodną formą do analizy wielu atrybutów jednocześnie. Ta forma prezentacji była wybierana do realizacji wielu zadań. Inne badania wskazywały, że wykres osi równoległych nie jest jednak preferowany przez badanych. Niniejsze badania wskazują na inny wniosek: badani, po zrozumieniu, jak należy analizować i interpretować tę formę prezentacji, nie unikali korzystania z niej. Ponadto E.L. Koua, A.M. MacEachren i M.-J. Kraak (2006) wnioskowali, że wykorzystanie wykresu do realizacji zadania typu „odczytaj wartość" (zadanie $1 \mathrm{w}$ przeprowadzonym badaniu) wymagało dwa razy więcej czasu niż użycie mapy. Z zebranych tutaj danych wynika, że ci, którzy byli zaklasyfikowani jako osoby z przewagą fiksacji na wykresie, nie różnią się pod względem rozwiązania zadania od osób z przewagą 
fiksacji na mapie. Badani chętnie korzystali z wykresu, zapewne dzięki możliwości filtrowania linii przez wybór powiatu oraz dzięki połączeniom z innymi modułami. Chęć korzystania z wykresu potwierdza również fakt, że w zadaniu numer 3 większość osób badanych cechowała się przewagą fiksacji na wykresie oraz wykorzystywała wykres do wyboru obiektów. W zadaniach 1 i 4 badani często korzystali z selekcji za pomocą innych modułów niż wykres, ale dzięki interaktywnemu połączeniu obiekty wybrane w innym module pozwoliły na odczytanie poszukiwanej informacji w tych zadaniach głównie za pomocą wykresu. Wszystkie te wyniki potwierdzają opinię R.M. Edsalla (2003), że funkcje interaktywne mogą stanowić pomoc przy rozwiązywaniu problemu zbytniego zgrupowania obiektów na wykresie. Okazuje się zatem, że nawet niepopularne metody, takie jak tabela czy wykres osi równoległych, mogą być chętnie, skutecznie i efektywnie wykorzystywane, jeśli będą wyposażone w odpowiednie funkcje interaktywne.

Podczas rozwiązywania rozmaitego typu zadań okazuje się, że różne moduły są używane nawet wtedy, gdy prezentują te same dane. Dowolność wyboru dogodnej formy prezentacji (z powodu przyzwyczajenia, doświadczenia, preferencji) do różnego typu operacji bez wątpienia jest cenną zaletą narzędzia wieloelementowego z redundancją treści. Różne metody były wybierane, ale nie rzutowało to na poprawność odpowiedzi. Jest to kolejne potwierdzenie tezy, że stosowanie jednocześnie różnych form prezentacji jest lepszym rozwiązaniem niż prezentowanie ich osobno. Odpowiednie funkcje interaktywne są kluczowe w efektywności złożonego narzędzia, nawet w przypadku zastosowania tak złożonej formy, jak wykres osi równoległych. 


\section{7. $\mid$ Wnioski}

\subsection{Semiotyka kartograficzna jako podstawa formułowania wniosków}

Semiotyka kartograficzna, jako punkt odniesienia w trakcie badania i oceny geowizualizacji wieloelementowych, umożliwia wskazanie ważnych aspektów projektowania i użytkowania tych opracowań. Ocena geowizualizacji z punktu widzenia pragmatyki, czyli użytkownika opracowania, stanowiła podstawę do przeprowadzenia badań empirycznych, w których zebrano bardzo duże ilości danych okulograficznych o szerokich możliwościach analizy zarówno jakościowej, jak i ilościowej.

Przeprowadzone badania umożliwiły ocenę przydatności redundancji danych prezentowanych w modułach testowanego opracowania. Należy także zwrócić uwagę, że z punktu widzenia semiotyki kartograficznej legenda odgrywa szczególnie istotną rolę w opracowaniu kartograficznym. W tym elemencie $w$ największym stopniu odzwierciedla się semantyczny aspekt opracowania. Z punktu widzenia pragmatycznego, a więc użytkownika mapy uczącego się opracowania, jest to również element szczególnie istotny. Znaczenie tego elementu wykazałam też $w$ badaniach empirycznych (także $z$ wykorzystaniem eye tracking), w których użytkownicy korzystali ze znanego im rodzaju opracowania (Havelková i Gołębiowska 2019; Opach, Gołębiowska i Fabrikant 2014): w obu tych badaniach zakres i sposób wykorzystania legendy okazał się istotny dla poprawności odczytywanych z nich informacji. W trakcie czytania map tematycznych to właśnie zakres odczytu legendy był jedną z głównych cech, które odróżniały rozkład uwagi wizualnej osób lepiej i gorzej odpowiadających na zadane pytania (Havelková i Gołębiowska 2019). Również w badaniach wieloelementowych map z zastosowaniem animacji badani lepiej rozwiązujący zadania cechowali się innym 
sposobem wykorzystania legendy (na początku i na końcu animacji) niż badani o niższym poziomie poprawności odpowiedzi (Opach, Gołębiowska i Fabrikant 2014).

Tym bardziej rola legendy wzrasta przy korzystaniu z opracowań nieznanych. W dalszych zatem rozważaniach, po podsumowaniu sposobu wykorzystania metody eye tracking $w$ badaniach geowizualizacji, nacisk zostanie położony na ten właśnie aspekt projektowania geowizualizacji wieloelementowych. Szczególna uwaga będzie zwrócona na legendę. Jak podaje T. Zarycki (2000), zdaniem wielu teoretyków trudne jest oddzielenie semiotyki od pragmatyki, ponieważ problemów skutecznego posługiwania się językiem (znakowym) nie można rozważać w oderwaniu od problemów jego znaczenia. Kwestia redakcji legendy wydaje się być tego adekwatnym wyrazem.

\subsection{Możliwości metody eye tracking w kontekście badań geowizualizacji wieloelementowych}

Metoda eye tracking to ogromna liczba danych o szerokich możliwościach ich analizy i wykorzystania. Możliwości te pokazały analizy przedstawione w rozdziałach 5.1 i 5.2. Ponadto zestawienie informacji dotyczących miejsc, na których skupia wzrok badana osoba, z informacjami pozyskanymi za pomocą innych metod, pozwala rozszerzyć potencjał wglądu w badane procesy użytkowania narzędzia geowizualizacji.

Rozważając analizę danych eye tracking zgromadzonych w trakcie pracy z geowizualizacjami wieloelementowymi, warto wskazać na wielość możliwych ścieżek. Zestawienie danych eye tracking z danymi z innych źródeł umożliwia uzyskanie wglądu, który można - w celu uporządkowania i syntezy - sprowadzić do dwóch aspektów analiz: zmian w czasie oraz interakcji. Analiza zmian w czasie wydaje się fundamentalna z punktu widzenia dyscypliny geovisual analytics, w której formułowane są wprost postulaty o treści „Think temporally!" (Andrienko i współautorzy 2010). Z kolei interakcja to aspekt, który wprowadził zasadnicze zmiany w sposobie myślenia o mapie i w sposobie pracy z mapą. Te dwa aspekty analiz pojawiały się w różnej konfiguracji w opisanych wcześniej badaniach. $\mathrm{Na}$ rycinie 7.1 zostały zestawione analizy przeprowadzone w ramach badań empirycznych wraz z oznaczeniem zakresu wykorzystania tych analiz razem z danymi eye tracking oraz informacją o numerze podrozdziału, w którym dana analiza była przedstawiana.

Zestawienie to pokazuje, jak szerokie możliwości są jeszcze przed metodą eye tracking i jednocześnie jak ważne są wielostronne analizy, 


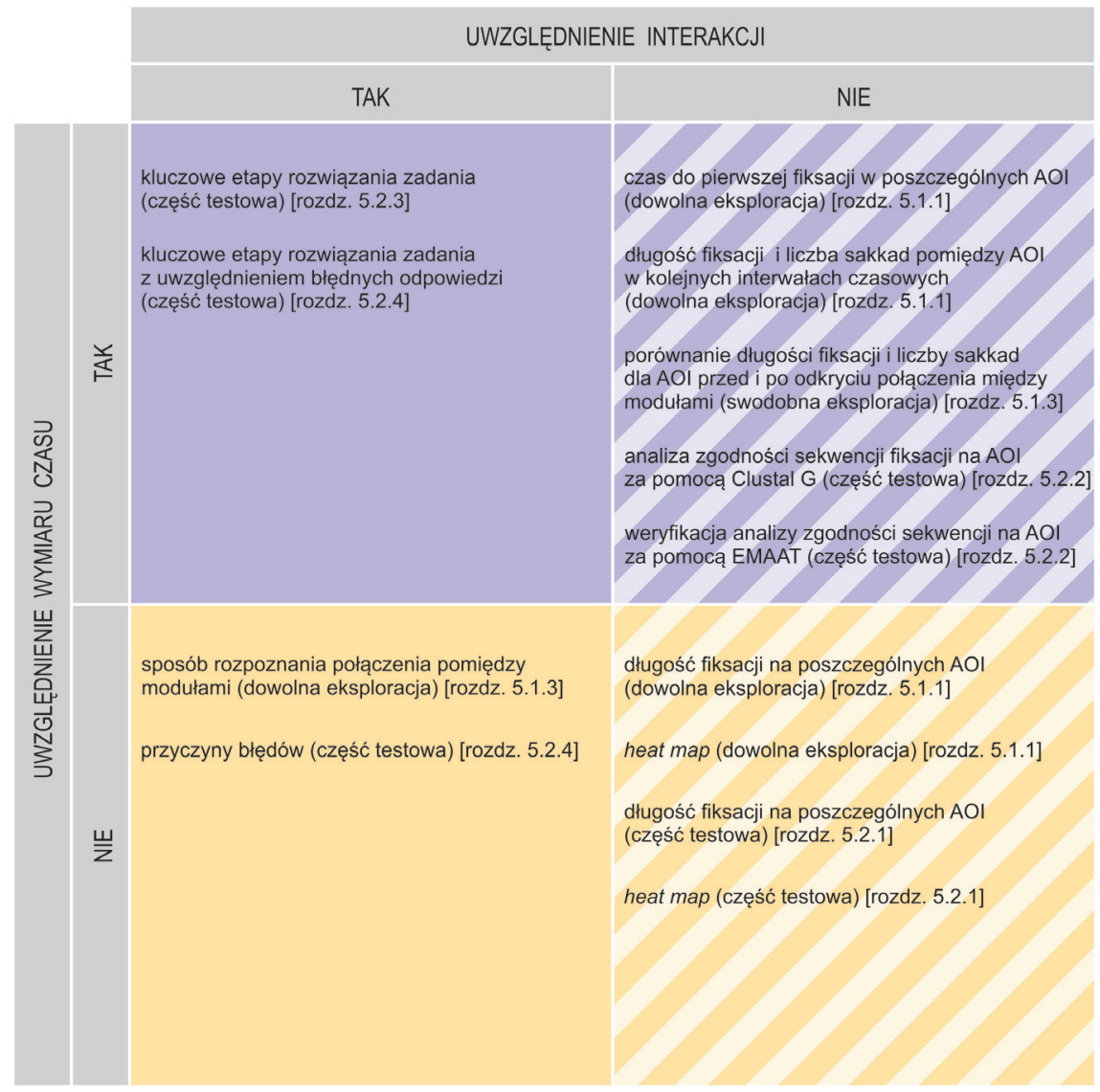

Rycina 7.1. Sposoby analizy danych eye tracking (uzupełnione innymi metodami badawczymi) z uwzględnieniem dwóch wymiarów: czasu oraz interaktywności

by unaocznić różne aspekty badanych procesów. Rozległe możliwości zestawiania tej metody z innymi pozwalają na szersze spojrzenie i odpowiednią interpretację oraz zrozumienie badanych procesów.

Analizy, które nie uwzględniają zmian w czasie, jak również nie odnoszą się do sposobu interakcji z narzędziem, to podstawowe wskaźniki oraz sposoby wizualizacji danych (długość fiksacji na AOI oraz wizualizacja w postaci mapy cieplnej - heat map). Pozwalają one dosyć ogólnie spojrzeć na badane procesy. Wzbogacenie analiz o kolejny wymiar, jakim jest czas, a dokładniej zmiany w czasie, pozwoliło na rozpatrywanie szerszego katalogu zagadnień, np. wyróżnianie strategii rozwiązania zadań w części testowej, zmianę uwagi wizualnej wraz z czasem, wpływ poznania połączeń pomiędzy modułami na podział uwagi wizualnej. 
Z pewnością cenne dla poznania pracy z wieloelementowymi narzędziami geowizualizacji jest zestawienie eye tracking $z$ danymi o wykorzystanych funkcjach interaktywnych. Uwzględnienie interakcji w ujęciu statycznym (bez uwzględnienia wymiaru czasu) pozwoliło na wskazanie sposobu poznania połączeń między modułami oraz przyczyn udzielenia błędnych odpowiedzi. Dopiero uwzględnienie w analizach interaktywności i jednocześnie zmian w czasie na kolejnych etapach rozwiązywania zadania pozwoliło potwierdzić przydatność redundancji w tego typu opracowaniach.

Taki sposób ujęcia analizy danych eye tracking jest nieco odmienny od rozbudowanych klasyfikacji prezentowanych przez G. Andrienkę i współautorów (2012) czy T. Blascheck i współautorów (2017). Uwzględnia bowiem jednocześnie dwa kluczowe elementy geowizualizacji: interakcję (MacEachren i Kraak 2001) oraz ujęcie czasowe w analizach na tej płaszczyźnie (Andrienko i współautorzy 2010). Jednocześnie przyjęty poziom ogólności tego zestawienia umożliwia uwzględnienie w tym ujęciu szeregu innych sposobów analiz danych eye tracking, również tych zestawionych i uzupełnionych innymi metodami zbierania danych empirycznych.

\subsection{Złożoność legendy geowizualizacji wieloelementowych}

\subsubsection{Dwa wymiary geowizualizacji}

Na podstawie przeprowadzonych badań można sformułować szersze wnioski dotyczące projektowania i użyteczności złożonych geowizualizacji. Z pewnością geowizualizacje wieloelementowe i inne narzędzia geowizualizacji trudno jest traktować jako konkurencyjne dla statycznych map, czy to papierowych, czy elektronicznych. Jest to rozszerzenie dotychczasowej perspektywy i umożliwienie użytkownikowi innego spojrzenia na dane przestrzenne. Zatem mapa uzyskuje wsparcie poprzez wykorzystanie innych metod, które mogą jej towarzyszyć w trakcie eksploracji danych przez użytkownika.

Kolejny istotny wniosek dotyczy zmiany spojrzenia na projektowanie tego typu opracowań. Łączenie map z innymi metodami prezentacji oznacza, że dla pełnej realizacji jej celów niezbędne jest zastosowanie interaktywności zarówno między modułami, jak też indywidualnie w poszczególnych modułach wykorzystujących różne formy prezentacji. Interaktywność staje się nieodłączną cechą tego rozwiązania. Należy zwrócić uwagę, że użytkownik uczący się narzędzia powinien poznać 
i zrozumieć dwie kwestie: sposób zakodowania informacji (symbolizacji) w ramach poszczególnych form prezentacji oraz, co jest równie ważne, powinien także zrozumieć, jak działają funkcje interaktywne. Zatem mamy do czynienia z dwiema warstwami informacji, które użytkownik powinien poznać, aby efektywnie korzystać z narzędzia. Projektując geowizualizację, trzeba więc rozważyć sposób przedstawienia obydwu zagadnień równocześnie, gdyż oba są ważne dla użytkownika. Jak określają A. Çöltekin i współautorzy (2020), projektowanie wizualizacji oraz projektowanie interakcji są zazwyczaj traktowane jako oddzielne zagadnienia, pomimo że są ze sobą ściśle powiązane. Autorzy wskazują, że być może wynika to $z$ faktu, że te zagadnienia pochodzą z innych dyscyplin.

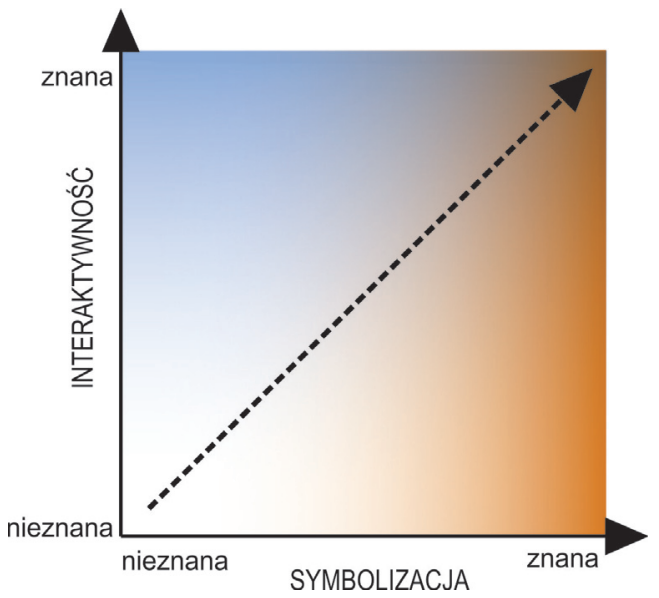

Rycina 7.2. Dwa wymiary geowizualizacji wieloelementowych, które użytkownik powinien poznać w celu efektywnego korzystania z nich

W trakcie nauki, poznając wyłącznie sposób symbolizacji, czyli rozpoznając, w jaki sposób dane są zakodowane, np. na mapie, pomija się ważny aspekt możliwości tego narzędzia. Miało to miejsce, gdy użytkownicy przyglądali się tylko narzędziu. Zatem na wykresie na ryc. 7.2 „poruszali się" tylko wzdłuż osi poziomej. Skutkowało to uznaniem, że opracowanie jest skomplikowane i trudne, nie znali bowiem możliwości drugiego wymiaru. W konsekwencji może to skutkować nawet rezygnacją z tego narzędzia. Z kolei w przypadku eksploracji wyłącznie narzędzia interaktywności, bez uzmysłowienia sobie, co prezentują zawarte dane, opracowanie stanie się „zabawką" do manipulacji i klikania. Nie będzie więc służyło do zrozumienia treści w nim zawartych ani do zdobywania nowej wiedzy i podejmowania świadomych decyzji. Na wykresie na ryc. 7.2 użytkownik będzie „przesuwał się” wzdłuż osi pionowej. Oba te 
scenariusze są niekorzystne, pomijają ważne aspekty geowizualizacji, nie wykorzystując jej potencjału.

Z optymalnym scenariuszem mamy do czynienia, gdy użytkownik oba wymiary poznaje w podobnym tempie. Odwołując się do ryciny 7.2 „porusza się" wzdłuż prostej oznaczonej linią przerywaną. Daje mu to możliwość jednoczesnego poznawania danych (oś symbolizacji), a także uświadomienia sobie, w jaki sposób manipulować nimi i je eksplorować (oś interaktywności), by dowiedzieć się o zjawisku możliwie najwięcej w możliwie najbardziej efektywny sposób.

\subsubsection{Poznawanie geowizualizacji wieloelementowej}

Sposób poznania geowizualizacji wieloelementowej można również zobrazować analogicznie do sześcianu użytkowania mapy, uwzględniając przy tym możliwości zakresu pracy i rodzaju zadań rozwiązywanych przy pomocy narzędzia (ryc. 7.3). Umieszczając dwie zmienne - znajomość symbolizacji oraz interakcji - jako kolejne osie sześcianu, w zestawieniu z trzecią zmienną - poziomem złożoności zadania, jakie można rozwiązać na podstawie geowizualizacji wieloelementowej, uzyskać można obraz typowej ścieżki pracy użytkownika tego typu opracowań. Praca z narzędziem rozpoczyna się zazwyczaj w narożniku, który symbolizuje brak znajomości zarówno symbolizacji, jak i sposobu pracy interaktywnej. Im mniejsza wiedza w obydwu tych zakresach, tym prostsze zadania mogą być rozwiązywane. Im bardziej złożone zadanie mamy do rozwiązania przy pomocy narzędzia, tym większa jest niezbędna wiedza, zarówno na temat znaczenia użytej symbolizacji, jak i zastosowanych technik interaktywnych.

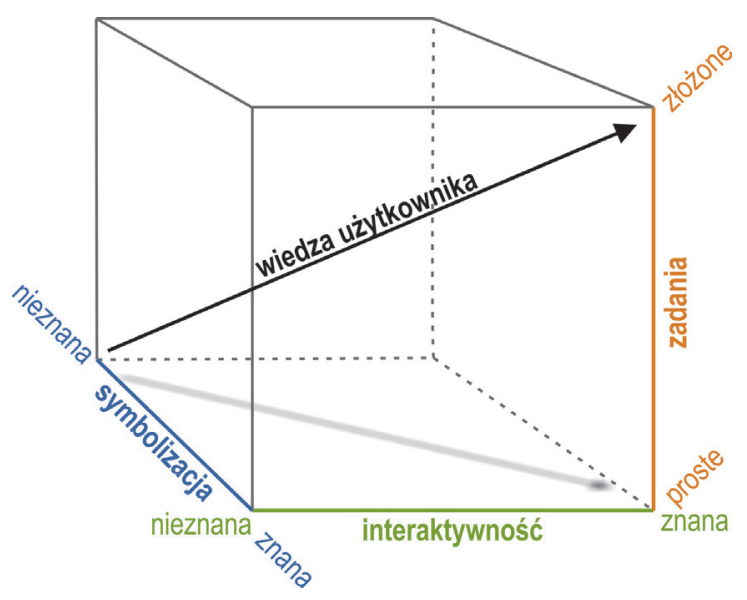

Rycina 7.3. Sześcian poznawania geowizualizacji wieloelementowej 
Z racji wysokiej wagi obydwu wymienionych aspektów opracowania, zwłaszcza w trakcie jego poznawania przez użytkownika, zarówno symbolizacja, jak i funkcje interaktywne powinny być przedstawione w jak najbardziej przystępny sposób, aby użytkownik poznał je możliwie najszybciej. To kieruje uwagę na ten aspekt redakcji narzędzia, jakim są elementy objaśniające. Legenda jest z pewnością kluczowym elementem, niezbędnym do zrozumienia większości map, jak również interaktywnych geowizualizacji (Gołębiowska 2015).

\subsubsection{Legenda geowizualizacji wieloelementowych}

W konsekwencji powyższych rozważań można rozszerzyć ujęcie legendy, która dotychczas traktowana była jako odkodowanie symbolizacji, stosowanej np. na mapie, o elementy interaktywności stosowane w całym narzędziu geowizualizacji, tak aby legendę potraktować całościowo. Rozważając strukturę geowizualizacji wieloelementowych i geowizualizacji ogółem, można wyróżnić legendę symbolizacji i legendę interaktywności. Takie szersze ujęcia legendy były już wcześniej postulowane, albowiem U. Freitag (1987; 2005), K. Kałamucki (2005), R. Sieber, C. Schmid i S. Wiesmann (2005) wskazywali, że termin „legenda” obejmuje zarówno wyjaśnienie symbolizacji znaków, jak i inne elementy pozaramkowe, które pozwalają na objaśnienie aspektów przestrzennych mapy. W ten sposób terminem legendy obejmują oni takie elementy, jak: skala mapy w różnej formie (np. podziałka liniowa), współrzędne geograficzne, mapa lokalizująca, tytuł informujący o położeniu itd. Czyli legenda odnosi się do pierwszego i drugiego podjęzyka mapy wyróżnionego przez A.A. Lutyja (1981). W środowisku geowizualizacji pojawił się nowy wymiar - interaktywność, który rzutuje na sposób pracy z mapą i całym narzędziem, w tym również rzutuje na legendę. Spojrzenie na mapę w kontekście interaktywności zostało uwzględnione przez A.M. MacEachrena (1995a), który rozbudował klasyczną listę zmiennych wizualnych (Bertin 1983) o szereg innych. Zatem modyfikacja spojrzenia na mapę, która nastąpiła w nowym kontekście interaktywności, jest podejściem z powodzeniem realizowanym i zrozumiałym $\mathrm{w}$ odniesieniu do różnego rodzaju map. Pozwala na uwzględnienie specyfiki tego typu opracowań, tak by jak najlepiej odzwierciedlić ich charakterystykę i uporządkować środki wyrazu, którymi się posługują.

W odniesieniu do wieloelementowych geowizualizacji legenda interaktywności, jako rozszerzenie klasycznie ujętej legendy, pozwala na ujęcie aspektów pracy podobnie ważnych z punktu widzenia użytkownika. 
Legenda interaktywności pomaga bowiem w poznaniu funkcji interaktywnych zastosowanych zarówno w obrębie modułów, poszczególnych metod, jak i pomiędzy modułami. Dotyczy to opisów, klawiszy, etykiet, list wyboru treści, narzędzi do filtrowania, interaktywnej zmiany sposobu wyświetlania treści (np. nadawanie przezroczystości itd.) i innych sposobów manipulowania danymi za pomocą interaktywnych funkcji.

Poprawnie zredagowana legenda symbolizacji pozwoli zatem użytkownikowi „przesuwać się” wzdłuż osi pionowej oznaczonej na ryc. 7.2. Z kolei skuteczna legenda interaktywności umożliwi rozszerzanie wiedzy użytkownika w trakcie nauki narzędzia wzdłuż osi poziomej. Celem jest oczywiście, aby obie legendy były również skuteczne, przystępne i dogodne dla użytkownika, aby mógł „przesuwać się” w podobnym tempie wzdłuż obu osi jednocześnie. W jaki sposób można pomóc użytkownikowi w harmonijnym poznawaniu obu aspektów? Rozwiązaniem wydaje się być sięgnięcie do rozwiązań znanych w kartografii.

Legenda mapy - to zagadnienie, które było przedmiotem rozważań i badań od wielu dekad. Sformułowane wnioski, zasady i zalecenia mają podbudowę zarówno teoretyczną (Freitag 1987; Slocum i współautorzy 2005; Pasławski 2010; Pieniążek i Zych 2017), jak i empiryczną (Li i Qin 2014; Gołębiowska 2015; Qin i Li 2017; Göbel i współautorzy 2018; Edler i współautorzy 2020). Z pewnością mogą one być pomocne przy projektowaniu i redakcji legendy geowizualizacji wieloelementowej. Jedną z zasad redakcji mapy jest nierozdzielanie legendy - powinna znajdować się w jednym miejscu. Zatem opracowując narzędzie interaktywne, warto legendę symbolizacji i legendę interaktywności potraktować jako spójny, jednolity element interfejsu, nie rozdzielając jej w miarę możliwości, ujednolicając jej założenia i redakcję w ramach obu aspektów: symbolizacji i interaktywności.

Takie rozszerzone ujęcie legendy odnosi się do każdej mapy interaktywnej. W odniesieniu do geowizualizacji wieloelementowych staje się niezwykle pomocnym podejściem w trakcie poszukiwania optymalnych rozwiązań redakcyjnych. Rozważając legendy geowizualizacji wieloelementowych, można również zaczerpnąć z innej praktyki na gruncie kartografii. Geowizualizacja wieloelementowa to prezentacja danych w postaci kilku elementów. Analogię takiego ujęcia można znaleźć w opracowaniach atlasów kartograficznych. Atlas to również jedno opracowanie, które składa się z wielu elementów, szeregu map, celowo ze sobą powiązanych wspólną ideą oraz wspólnymi sposobami jej kartograficznej realizacji (Horodyski 1979; 2006). Rozważając legendę w węższym ujęciu, jako objaśnienie znaków, warto zwrócić uwagę na fakt, że w opracowaniach atlasowych stosowane są rozwiązania polegające na zebraniu wykorzystanych $w$ atlasie 
znaków do legendy zbiorczej dla całego atlasu. Tego typu legendy mają pomóc użytkownikowi w zapoznaniu się z zakresem treści całego atlasu, dzięki czemu może on odnaleźć w jednym miejscu wszystkie znaki i ich znaczenie. Może również zorientować się o zakresie tematycznym całego opracowania, a nie tylko pojedynczej mapy. Innym atutem takiego rozwiązania jest fakt, że użytkownik - po określeniu położenia legendy zbiorczej w opracowaniu atlasowym - zawsze wie, gdzie ma sięgać, chcąc odczytać znaczenie znaków. Jest to jednocześnie zgodne z wnioskami sformułowanymi przez R. Schnürera, R. Siebera i A. Çöltekin (2015) odnośnie do interfejsu atlasu elektronicznego. Autorzy zalecali bowiem, by wprowadzić grupowanie narzędzi o podobnej funkcji w obrębie interfejsu, unikając rozmieszczenia ich w różnych miejscach ekranu.

Analogicznie w geowizualizacjach wieloelementowych poszczególne moduły można również wyjaśnić w jednym miejscu, tak by użytkownik nie musiał szukać wyjaśnień w różnych częściach interfejsu. W ten sposób użytkownik ma w jednym miejscu zebrane wszystkie objaśnienia. Zawsze wie, gdzie sięgnąć, gdy chce się zapoznać ze znaczeniem niezrozumiałych elementów lub funkcji. W przypadku elementów wyjaśniających rozmieszczonych w różnych miejscach interfejsu, w obrębie poszczególnych modułów, istnieje ryzyko, że użytkownik odnajdzie tylko część wyjaśnień, natomiast części z nich nie zauważy. Nie zapozna się tym samym z pełnym zakresem funkcji narzędzia. Zatem zebranie w jednym miejscu wszystkich wyjaśnień, dotyczących zarówno sfery symbolizacji, jak i interakcji, ma niewątpliwe zalety. Legenda, traktowana całościowo i w miarę możliwości spójna dla wszystkich modułów, umożliwi, by zasady zrozumiane przez użytkownika na podstawie pracy w jednym module miały zastosowanie w czasie pracy w kolejnym module.

Należy jednak zauważyć, że takie rozwiązanie w postaci legendy zbiorczej może doprowadzić do złamania jednej z zasad psychologii Gestalt, która jest zalecana w trakcie projektowania interfejsów, a przydatność tej teorii przy projektowaniu legend została również empirycznie dowiedziona (Medyńska-Gulij 2007a; Li i Qin 2014; Qin i Li 2017). W ramach psychologii Gestalt sformułowano zasady, które wyjaśniają, w jaki sposób mózg organizuje widziane elementy. Jedna z tych zasad - zasada bliskości - mówi, że obiekty, które znajdują się blisko siebie, są traktowane jako całość. W przypadku gdy element wyjaśniający będzie przeniesiony z modułu do legendy zbiorczej, jego połączenie z modułem, do którego się odnosi, może być trudniejsze, niż gdyby znajdował się w jego bezpośrednim sąsiedztwie. Zatem nie można traktować takiego sposobu projektowania legendy jako idealnego w każdym przypadku. Zależy to - jak w przypadku redakcji każdego opracowania 
kartograficznego - od przeznaczenia geowizualizacji. Z pewnością warto jednak mieć na uwadze traktowanie tak ujętej legendy jako całości w celu jej spójnego i harmonijnego zredagowania.

\subsection{Konsekwencje uwzględnienia złożoności legendy geowizualizacji wieloelementowych}

Projektując wieloelementowe narzędzie geowizualizacji, warto rozważyć przedstawiony powyżej sposób ujęcia i objaśnienia jego treści oraz funkcjonalności. Należy zaznaczyć, że zaproponowane postępowanie jest rozwiązaniem modelowym, którego wdrożenie nie zawsze jest w pełni możliwe. Istnieją bowiem przypadki, w których zgrupowanie elementów wyjaśniających w jednym miejscu graficznego interfejsu użytkownika, w oderwaniu od prezentacji, do których się odnoszą, może być trudne do realizacji. Przykładem na testowanym narzędziu są opisy poszczególnych osi na wykresie osi równoległych lub nagłówki kolumn w module z tabelą (ryc. 4.1).

Sposobem na zilustrowanie złożoności legendy geowizualizacji wieloelementowej może być projektowanie narzędzia o nazwie ClimRes, opracowanego w Zakładzie Geografii Norweskiego Uniwersytetu Nauki i Technologii (NTNU) w ramach projektu KlimaForsk (Opach i Rød 2018). W kilku oknach prezentowane są tu dane dotyczące odszkodowań z tytułu szkód wyrządzonych przez klęski żywiołowe w Norwegii. Dane prezentowane są na poziomie powiatów (norweskie kommuner) w poszczególnych latach w okresie 1980-2018 i dotyczą bezwzględnej wysokości odszkodowań oraz liczby zarejestrowanych szkód według ich rodzaju, wysokości odszkodowań w przeliczeniu na zarejestrowane szkody oraz w przeliczeniu na liczbę mieszkańców. Narzędzie ClimRes zawiera trzy moduły, które w różnej formie prezentują te same dane. Największą cześć ekranu zajmują mapa tematyczna (jest to kartodiagram ciągły dla danych bezwzględnych lub kartogram dla danych względnych), wykres słupkowy oraz tabela.

Jak można zauważyć, elementy wyjaśniające symbolizację (legenda mapy), elementy umożliwiające filtrowanie treści (lista powiatów obok tabeli) czy też zmiany roku rozmieszczone są niezależnie od siebie i w odległych miejscach. Dla projektantów jest to ułatwienie, gdyż mogą dowolnie łączyć różne okna, które mając przypisane elementy objaśniające i sterujące, mogą funkcjonować niezależnie od pozostałych okien. W przypadku grupowania elementów objaśniających projektant powinien każdorazowo dostosować je do całości interfejsu, co często stanowi wyzwanie projektowe oraz jest pracochłonne. Z punktu widzenia 


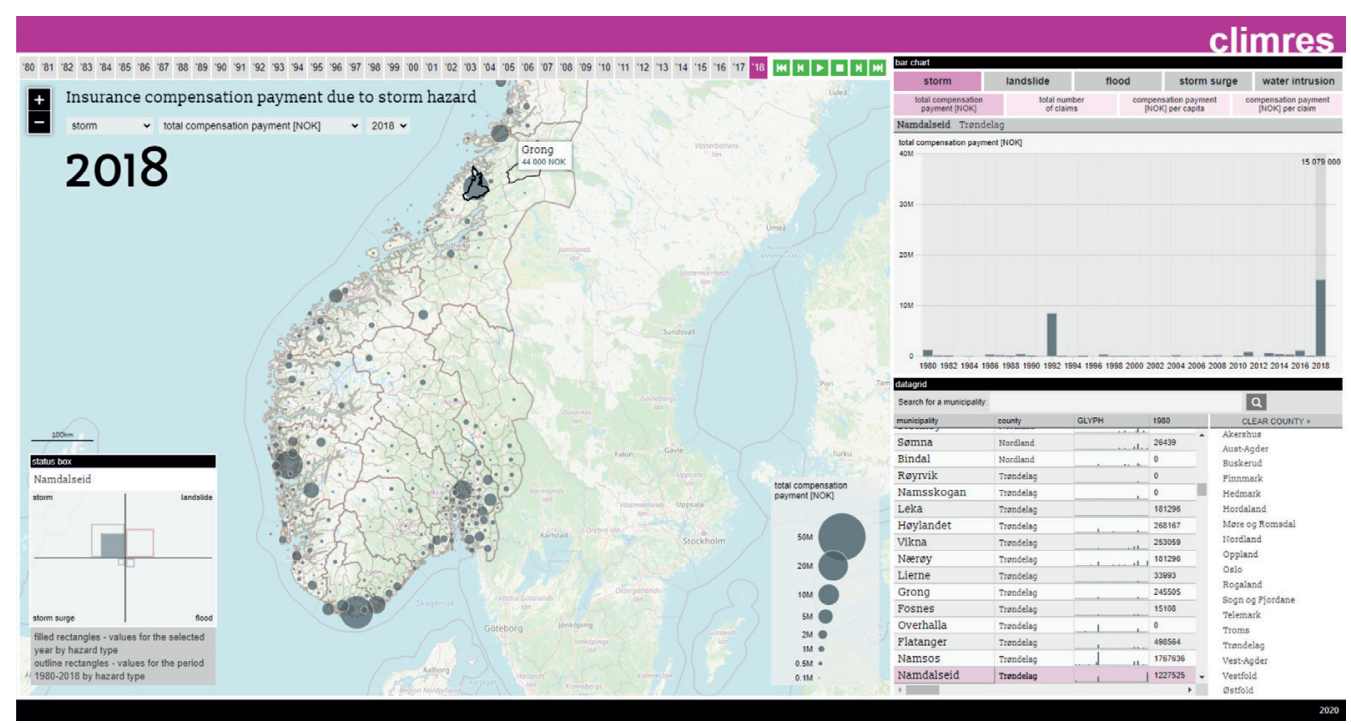

Rycina 7.4. Narzędzie ClimRes przed zmianą legendy symbolizacji i legendy interaktywności

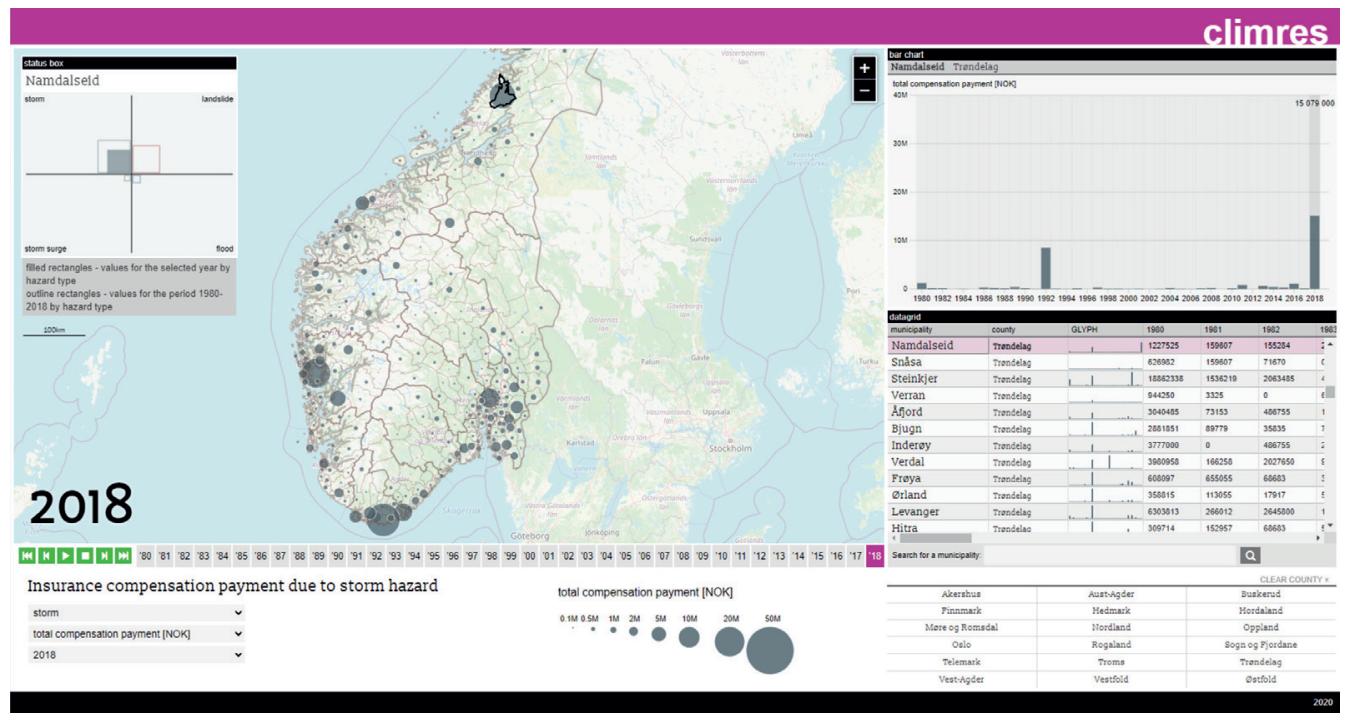

Rycina 7.5. Interfejs wieloelementowego narzędzia geowizualizacji po przeprojektowaniu: z jedną legendą odnoszącą się do wszystkich modułów 
użytkownika niezależne projektowanie modułów skutkuje powtórzeniem funkcji (wybór wskaźników i prezentowanych danych odbywa się kilkakrotnie: w ramach mapy oraz wykresu słupkowego). Powtórzenie tych elementów powoduje wykorzystanie większej powierzchni ekranu, a w konsekwencji pozostaje mniej miejsca dostępnego dla zasadniczej treści prezentującej te dane: mapę, wykres i tabelę.

Interfejs taki można jednak przebudować, wykorzystując sformułowane powyżej wnioski. Rycina 7.5 pokazuje następujące możliwości zastosowania tych zasad:

1) zarówno symbolizacja, jak i funkcje interaktywne są umieszczone w miarę możliwości razem,

2) treści odnoszące się do wszystkich modułów są tłumaczone w jednym miejscu.

W wyniku przeprojektowania interfejsu i innego rozmieszczenia jego elementów objaśniających wyodrębniono panel w dolnej części ekranu, w którym zgrupowano - w miarę możliwości - elementy objaśniające. Odnosi się to zarówno do objaśnienia symboli, jak i filtrowania obiektów czy zmiany danych do wyświetlenia. Dzięki temu, że elementy objaśniające znajdują się w jednym miejscu, a zatem nie ma potrzeby poszukiwania ich w graficznym interfejsie użytkownika, nie powtarza się tych samych elementów służących do wyboru danych.

Przytoczony tutaj przykład pokazuje możliwości modyfikacji narzędzi geowizualizacji dzięki ujęciu tej problematyki z punktu widzenia zagadnień rozważanych od dawna w kartografii. Pokazuje to, że pole do wykorzystania w ramach geowizualizacji wniosków oferowanych przez kartografię nie zostało jeszcze w pełni wykorzystane. Potencjał leżący w tego typu podejściu może być większy, niż się spodziewamy. 


\section{Podsumowanie}

Tradycyjne problemy kartograficzne, takie jak wykorzystanie redundancji na mapach, a tym samym skuteczne formowanie przekazu kartograficznego na jego poziomie semantycznym, jak również skuteczne projektowanie legendy warunkujące efektywność na poziomie pragmatycznym, są nadal aktualne także w kontekście geowizualizacji wieloelementowych. Wprawdzie te problemy, zaczerpnięte z semiotyki, były od dekad wielokrotnie podejmowane na płaszczyźnie kartografii, jednak wciąż mogą one stanowić teoretyczną osnowę ułatwiającą zrozumienie zasad, których przestrzeganie jest niezbędne do przygotowania efektywnych geowizualizacji wieloelementowych, również w odniesieniu do zakresu oraz sposobu wykorzystania funkcji interaktywnych.

Rozwój geowizualizacji daje możliwość, z jednej strony, wykorzystania bogatego dorobku kartografii na nowej płaszczyźnie, a z drugiej - wykorzystania dorobku (geo)wizualizacji we współczesnej kartografii. Po osadzeniu w odpowiednim kontekście nurty badawcze klasycznej kartografii mogą być więc rozwijane na gruncie geowizualizacji. Czerpanie z dorobku kartografii okazuje się odpowiednim podejściem w odniesieniu do geowizualizacji, gdyż wzbogaca i odpowiednio porządkuje perspektywę badawczą, nie ograniczając jej do zagadnień ściśle technologicznych. Ujęcie wyłącznie technologiczne należy bowiem uznać za istotne zubożenie działające na niekorzyść użytkowników. Korzyści płynące z synergii z pewnością są wszechstronne. Jedną z nich może być opracowanie użytecznych, chociaż złożonych geowizualizacji wieloelementowych. Narzędzia te są wyzwaniem zarówno dla projektanta, jak i użytkownika; tego ostatniego mogą one czasami nawet skutecznie zniechęcić. Jednocześnie - jak zostało wykazane - mogą być efektywne, a nawet oceniane jako tatwe i przystępne do eksploracji złożonych zestawów danych.

Warto podkreślić ważną rolę mapy w tego typu opracowaniach: nadal jest ona niezbędna, gdy chodzi o wizualizację, wizualny wgląd 
w dane przestrzenne w celu ich poznania. Mapa posiada wyjątkowe cechy i możliwości, zwłaszcza w kontekście GEOwizualizacji. W zestawieniu z innymi formami prezentacji będzie ona wspierana i przez nie uzupełniana. Inne formy wizualizacji będą z pewnością pomocne w zestawieniu z mapą, z powodu na przykład chęci skorzystania przez użytkownika z formy preferowanej (np. z przyzwyczajenia) lub ze względu na specyfikę poszukiwanej informacji. Nie można jednak uznać, że mapa będzie zastąpiona przez szereg innych form prezentacji danych.

Przeprowadzone rozważania natury teoretycznej oraz badania o charakterze empirycznym pozwoliły na osiągnięcie postawionych celów. Cele sformułowane we wprowadzeniu obejmowały ocenę przydatności redundancji $w$ trakcie projektowania geowizualizacji wieloelementowej (cel poznawczy), rozwinięcie metodyki okulografii (eye tracking) w zakresie analizy danych $w$ badaniach wieloelementowych narzędzi geowizualizacji (cel metodyczny) i określenie sposobu poznania geowizualizacji wieloelementowych przez niedoświadczonych użytkowników i na tej podstawie formułowanie wskazówek dla osób projektujących tego typu opracowania (cel utylitarny).

Przyjęty zestaw metod badań empirycznych w postaci eye tracking, rejestru interakcji, protokołów głośnego myślenia oraz poprawności odpowiedzi pozwolił na zebranie zróżnicowanych danych i analizę procesu wykorzystania geowizualizacji wieloelementowej pod wieloma kątami, a w związku z tym - na sformułowanie wniosków. Umożliwiło to między innymi wskazanie ważnej roli legendy w projektowaniu i użytkowaniu takich opracowań, a co za tym idzie - w ich użyteczności. Uzyskane wyniki pozwoliły na sformułowanie modelu poznawania geowizualizacji wieloelementowych, a także na szersze ujęcie ich legendy, która dzięki temu może być projektowana w sposób spójny i harmonijny - przy uwzględnieniu specyfiki takich opracowań.

Za raczej mało prawdopodobny można uznać scenariusz, że po okresie zainteresowania naukowców czy też dużej popularności tego typu aplikacji, na przykład w czasach pandemii COVID-19 (Dong, Du i Gardner 2020), popadną one w zapomnienie, a wraz z nimi - koncepcja geowizualizacji wieloelementowych. Można się spodziewać rozwoju koncepcji i wyzwań za nimi stojących, takich jak rozbudowanie animacji, opracowania mobilne, przeniesienie do rzeczywistości rozszerzonej lub wirtualnej. Z pewnością w tym rozwoju koncepcji i coraz bardziej zaawansowanych rozwiązań technologicznych ważne są fundamenty teoretyczne. Te ostatnie oferuje semiotyka kartograficzna, która umożliwia spojrzenie na mapę w kontekście innych form prezentacji danych, dzięki temu wykracza poza tradycyjne ramy mapy, której forma i funkcja nie przestają ewoluować. 
Niewątpliwie warto kontynuować badania dotyczące użyteczności wieloelementowych geowizualizacji, tak by zapewnić ich przystępność, również przy pierwszym kontakcie. Niemalejące tempo rozwoju technologicznego skutkuje i nadal będzie skutkowało kolejnymi wyzwaniami i rozwiązaniami, które można włączyć do geowizualizacji różnego typu. Zawsze jednak rozbudowanie geowizualizacji musi się odbywać z uwzględnieniem ważnej roli użytkownika, tak by oferować duże możliwości analizy, ale jednocześnie nadal stanowić pomocne i dogodne narzędzie pracy oraz poznawania nieznanych - a coraz bogatszych - danych. 


\section{Literatura}

Amar R., Eagan J., Stasko J. (2005), Low-level components of analytic activity in information visualization, IEEE Symposium on Information Visualization, IEEE, Los Alamitos, s. 111-117.

Andrienko G., Andrienko N. (2007), Coordinated multiple views. A critical view, [w:] Fifth International Conference on Coordinated and Multiple Views in Exploratory Visualization (CMV 2007), IEEE , s. 72-74, https://doi.org/10.1109/ CMV.2007.4.

Andrienko G., Andrienko N., Burch M., Weiskopf D. (2012), Visual analytics methodology for eye movement studies, „IEEE Transactions on Visualization and Computer Graphics", nr 18(12), s. 2889-2898, https://doi.org/10.1109/ TVCG.2012.276.

Andrienko G., Andrienko N., Demsar U., Dransch D., Dykes J., Fabrikant S.I., Jern M., Kraak M.-J., Schumann H., Tominski C. (2010), Space, time and visual analytics, „International Journal of Geographical Information Science”, nr 24(10), s. 1577-1600, https://doi.org/10.1080/13658816.2010.508043.

Andrienko G., Andrienko N., Dykes J., Kraak M.-J., Robinson A., Schumann H. (2016), GeoVisual analytics: Interactivity, dynamics, and scale, „Cartography and Geographic Information Science", nr 43(1), s. 1-2, https://doi.org/10.1 080/15230406.2016.1095006.

Andrienko G., Andrienko N., Jankowski P., Keim D., Kraak M.-J., MacEachren A.M., Wrobel S. (2007), Geovisual analytics for spatial decision support: Setting the research agenda, „International Journal of Geographical Information Science", nr 21(8), s. 839-857, https://doi.org/10.1080/13658810701349011.

Andrienko N., Andrienko G. (2001), Intelligent support for geographic data analysis and decision making in the web, „Journal of Geographic Information and Decision Analysis", nr 5(2), s. 115-128.

Andrienko N., Andrienko G. (2006a), Exploratory analysis of spatial and temporal data. A systematic approach, Springer, Berlin-Heidelberg.

Andrienko N., Andrienko G. (2006b), The complexity challenge to creating useful and usable geovisualization tools, [w:] Geographic Information Science: Fourth International Geoconference, GIScience, red. M. Raubal, Verlag Natur \& Wissenschaft, Münster, s. 23-27. 
Andrienko N., Andrienko G., Voss H., Bernardo F., Hipolito J., Kretchmer U. (2002), Testing the usability of interactive maps in CommonGIS, "Cartography and Geographic Information Science", nr 29(4), s. 325-342, https://doi. org/10.1559/152304002782008369.

Asłanikaszwili A.F. (1974), Metakartografija. Osnownyje problemy, Miecniereba, Tbilisi. Auer E., Russel A., Sloetjes H., Wittenburg P., Schreer O., Masnieri S., Schneider D., Tschöpel S. (2010), ELAN as flexible annotation framework for sound and image processing detectors, [w:] Seventh Conference on International Language Resources and Evaluation (LREC'10), Malta: 17th-23rd May, European Language Resources Association, Valetta, s. 890-893.

Baldonado M.Q.W., Woodruff A., Kuchinsky A. (2000), Guidelines for using multiple views in information visualization, [w:] AVI 'OO Proceedings of the Working Conference on Advanced Visual Interfaces, ACM, New York, s. 110-119.

Behrens J., Elzakker C.P.J.M. van, Schmidt M. (2015), Testing the usability of OpenStreetMap's ID Tool, „The Cartographic Journal”, nr 52(2), s. 177-184, https://doi.org/10.1080/00087041.2015.1119457.

Berlant A.M. (1993a), Geoikonometria, „Polski Przegląd Kartograficzny”, nr 25(4), s. $165-172$.

Berlant A.M. (1993b), Geoprzedstawienia i geoikonika, „Polski Przegląd Kartograficzny", nr 25(3), s. 105-115.

Berlant A.M. (1999), Sieci komputerowe a kartografia, „Polski Przegląd Kartograficzny", nr 31(2), s. 83-91.

Berlant A.M. (2000), Kartowanie geoinformacyjne - koncepcja i podstawy geograficzne, „Polski Przegląd Kartograficzny”, nr 32(1), s. 2-10.

Bertin J. (1967), Semiologie graphique. Les diagrammes, les reseaux, les cartes, Mouton et Gouthier-Villars, La Haye-Paris.

Bertin J. (1983), Semiology of graphics: Diagrams, networks, maps, University of Wisconsin Press, Madison.

Bhowmick T., Robinson A.C., Gruver A., MacEachren A.M., Lengerich E.J. (2008), Distributed usability evaluation of the Pennsy/vania Cancer Atlas, „International Journal of Health Geographics", nr 7(1), https://doi.org/10.1186/1476072X-7-36.

Biecek P. (2016), Odkrywać! Ujawniać! Objaśniać! Zbiór esejów o sztuce prezentowania danych, http://www.biecek.pl/Eseje/indexObraz.html.

Bishop I.D., Pettit C.J., Sheth F., Sharma S. (2013), Evaluation of data visualisation options for land-use policy and decision making in response to climate change, „Environment and Planning B: Planning and Design”, nr 40(2), s. 213-33, https://doi.org/10.1068/b38159.

Blascheck T., Kurzhals K., Raschke M., Burch M., Weiskopf D., Ertl T. (2017), Visualization of eye tracking data: A taxonomy and survey, „Computer Graphics Forum", nr 36(8), s. 260-284, https://doi.org/10.1111/cgf.13079.

Borji A., Sihite D.N., Itti L. (2013), What stands out in a scene? A study of human explicit saliency judgment, „Vision Research”, nr 91 (October), s. 62-77, https://doi.org/10.1016/j.visres.2013.07.016.

Bouissac P. (1991), Ikoniczność i stosowność, [w:] Semiotyka wczoraj i dziś, red. J. Pelc, L. Koj, Ossolineum, Zakład Semiotyki Logicznej Uniwersytetu Warszawskiego, Polskie Towarzystwo Semiotyczne, Wrocław, s. 117-135. 
Brewer C.A. (1997), Spectral schemes: Controversial color use on maps, „Cartography and Geographic Information Science”, nr 24(4), s. 203-20, https:// doi.org/10.1559/152304097782439231.

Buttenfield B. (1999), Usability evaluation of digital libraries, „Science \& Technology Libraries", nr 17(3-4), s. 39-59, https://doi.org/10.1300/J122v17n03_04.

Castner H.W., Eastman R.J. (1984), Eye-movement parameters and perceived map complexity-l, „The American Cartographer”, nr 11(2), s. 107-117, https:// doi.org/10.1559/152304084783914768.

Castner H.W., Eastman R.J. (1985), Eye-movement parameters and perceived map complexity-II, „The American Cartographer”, nr 12(1), s. 29-40, https:// doi.org/10.1559/152304085783914712.

Chang K.T., Antes J., Lenzen T. (1985), The effect of experience on reading topographic relief information: Analyses of performance and eye movements, „The Cartographic Journal”, nr 22(2), s. 88-94, https://doi.org/10.1179/ caj.1985.22.2.88.

Chi M.T.H. (1997), Quantifying qualitative analyses of verbal data: A practical guide, „Journal of the Learning Sciences”, nr 6(3), s. 271-315, https://doi. org/10.1207/s15327809jls0603_1.

Convertino G., Chen J., Yost B., Ryu Y.-S., North C. (2003), Exploring context switching and cognition in dual-view coordinated visualizations, Proceedings International Conference on Coordinated and Multiple Views in Exploratory Visualization CMV 2003, IEEE, s. 55-62, https://doi.org/10.1109/CMV.2003.1215003.

COVID-19 Dashboard by the Center for Systems Science and Engineering (CSSE) (2020) at Johns Hopkins University (JHU), https://coronavirus.jhu.edu/map. html, dostęp 25.07.2021.

Cybulski P., Medyńska-Gulij B. (2018), Cartographic redundancy in reducing change blindness in detecting extreme values in spatio-temporal maps, „ISPRS International Journal of Geo-Information", nr 7(8), https://doi.org/10.3390/ijgi7010008.

Czerny A., Kałamucki K., Ostrowski W., Żyszkowska W. (1999), Dorobek i stan polskiej kartografii geograficznej w ostatnim dziesięcioleciu, „Polski Przegląd Kartograficzny", nr 31(1), s. 3-14.

Çöltekin A. (2019), What contributes to the complexity of visuospatial displays?, Abstraction, Scale and Perception. International Cartographic Association Joint Commission Workshop, s. 1-2.

Çöltekin A., Bleisch S., Andrienko G., Dykes J. (2017), Persistent challenges in geovisualization - a community perspective, „International Journal of Cartography”, nr 3 (supl. 1), s. 115-39, https://doi.org/10.1080/23729333.2017.1302910.

Çöltekin A., Christophe S., Robinson A., Demšar U. (2019), Designing geovisual analytics environments and displays with humans in mind, „ISPRS International Journal of Geo-Information", nr 8(12), https://doi.org/10.3390/ijgi8120572.

Çöltekin A., Griffin A., Robinson A. (2021), Visualizations, [w:] Geography, red. B. Warf, Oxford University Press, Oxford, https://doi.org/10.1093/ obo/9780199874002-0224.

Çöltekin A., Heil B., Garlandini S., Fabrikant S.I. (2009), Evaluating the effectiveness of interactive map interface designs: A case study integrating usability metrics with eye-movement analysis, „Cartography and Geographic Information Science", nr 36(1), s. 5-17, https://doi.org/10.1559/152304009787340197. 
Çöltekin A., Janetzko H., Fabrikant S. (2018), Geovisualization, „Geographic Information Science \& Technology Body of Knowledge", red. J.P. Wilson, https:// doi.org/10.22224/gistbok/2018.2.6.

Çöltekin A., Lochhead I., Madden M., Christophe S., Devaux A., Pettit C., Lock O. (2020), Extended reality in spatial sciences: A review of research challenges and future directions, „ISPRS International Journal of Geo-Information”, nr 9(7), s. 439, https://doi.org/10.3390/ijgi9070439.

Demšar U. (2007), Investigating visual exploration of geospatial data: An exploratory usability experiment for visual data mining, „Computers, Environment and Urban Systems", nr 31(5), s. 551-571, https://doi.org/10.1016/j.compenvurbsys.2007.08.006.

DiBiase D. (1990), Visualization in the Earth Sciences. Earth and Mineral Sciences, „Bulletin of the College of Earth and Mineral Sciences. Pennsylvania State University", nr 59(2), s. 13-18.

DiBiase D., MacEachren A.M., Krygier J.B., Reeves C. (1992), Animation and the role of map design in scientific visualization, "Cartography and Geographic Information Systems", nr 19(4), s. 201-214, https://doi. org/10.1559/152304092783721295.

Dobraja I., Kraak M.-J. (2020), Principles of dashboard adaptability to get insights into origin-destination data, „Journal of Location Based Services”, nr 14(1), s. 28-48, https://doi.org/10.1080/17489725.2020.1738577.

Dobraja I., Kraak M.-J., Engelhardt Y. (2018), Facilitating insights with a user adaptable dashboard. Illustrated by Airport Connectivity Data, Proceedings of the ICA 1 (May), s. 1-6, https://doi.org/10.5194/ica-proc-1-30-2018.

Dobson M.W. (1977), Eye movement parameters and map reading, „The American Cartographer", nr 4(1), s. 39-58, https://doi.org/10.1559/1523040777840 80022.

Dobson M.W. (1979), The influence of map information on fixation localization, „The American Cartographer”, nr 6(1), s. 51-65, https://doi. org/10.1559/152304079784022772.

Dobson M.W. (1983), Visual information processing and cartographic communication: The utility of redundant stimulus dimensions, [w:] Graphic communication and design in contemporary cartography, red. D.R.F. Taylor, John Wiley and Sons, Chichester.

Dolezalova J., Popelka S. (2016), ScanGraph: A nove/ scanpath comparison method using visualisation of graph cliques, „Journal of Eye Movement Research”, nr 9(4), https://doi.org/10.16910/jemr.9.4.5.

Dong E., Du H., Gardner L. (2020), An interactive web-based dashboard to track COVID-19 in real time, „The Lancet Infectious Diseases”, nr 20(5), s. 533-534, https://doi.org/10.1016/S1473-3099(20)30120-1.

Dong W., Yang T., Liao H., Meng L. (2020a), How does map use differ in virtual reality and desktop-based environments?, „International Journal of Digital Earth", February, s. 1-20, https://doi.org/10.1080/17538947.2020.1731617.

Dong W., Zhan Z., Liao H., Meng L., Liu J. (2020b), Assessing similarities and differences between males and females in visual behaviors in spatial orientation tasks, „ISPRS International Journal of Geo-Information”, nr 9(2), s. 115, https://doi.org/10.3390/ijgi9020115. 
Duchowski A.T. (2007), Eye tracking methodology - theory and practice, Springer, London.

Dukaczewski D. (2019), Encyjna metodyka projektowania czasowo-przestrzennych animacji kartograficznych, Instytut Geodezji i Kartografii, Warszawa.

Dupont L., Ooms K., Antrop M., Eetvelde V. Van (2017), Testing the validity of a saliency-based method for visual assessment of constructions in the landscape, „Landscape and Urban Planning”, nr 167 (November), s. 325-338, https://doi.org/10.1016/j.landurbplan.2017.07.005.

Dykes J. (1997), Exploring spatial data representation with dynamic graphics, „Computers \& Geosciences”, nr 23(4), s. 345-370, https://doi.org/10.1016/ S0098-3004(97)00009-5.

Dykes J., MacEachren A.M., Kraak M.-J. (2005), Exploring geovisualization, Elsevier Ltd., Amsterdam.

Edler D., Keil J., Tuller M.C., Bestgen A.K., Dickmann F. (2020), Searching for the 'Right' legend: The impact of legend position on legend decoding in a cartographic memory task, „The Cartographic Journal”, nr 57(1), s. 6-17, https://doi.org/10.1080/00087041.2018.1533293.

Edsall R.M. (2003), Design and usability of an enhanced geographic information system for exploration of multivariate health statistics, "The Professional Geographer", nr 55(2), s. 146-160.

Edsall R.M., Deitrick S. (2009), Case studies demonstrating the utility of unconventional designs for geographic problem solving, 24th International Cartographic Conference Santiago de Chile, Chile: 15-21 November.

Ericsson K.A., Simon H.A. (1980), Verbal reports as data, „Psychological Review”, nr 87(3), s. 215-251, https://doi.org/10.1037/0033-295X.87.3.215.

Ericsson K.A., Simon H.A. (1993), Protocol analysis: Verbal reports as data, MIT Press, Cambridge, Massachusetts.

Fabrikant S.I., Hespanha S.R., Andrienko N., Andrienko G., Montello D.R. (2008), Novel method to measure inference affordance in static small-multiple map displays representing dynamic processes, „The Cartographic Journal”, nr 45(3), s. 201-215, https://doi.org/10.1179/000870408X311396.

Fabrikant S.I., Hespanha S.R., Hegarty M. (2010), Cognitively inspired and perceptually salient graphic displays for efficient spatial inference making, „Annals of the Association of American Geographers", nr 100(1), s. 13-29, https://doi.org/10.1080/00045600903362378.

Fairbairn D., Andrienko G., Andrienko N., Buziek G., Dykes J. (2001), Representation and its relationship with cartographic visualization: A research agenda, „Cartography and Geographic Information Science”, nr 28(1), s. 13-28, https:// doi.org/10.1559/152304001782174005.

Ferrara J. (2012), Playful design, O'Reilly Media, Sebastopol, California.

Freitag U. (1971), Semiotik und Kartographie. Über die Anwendung kybernetischer Disziplinen in der theoretischen Kartographie, „Kartographische Nachrichten”, nr 21(5), s. 171-182.

Freitag U. (1987), Die Kartenlegende - nur eine Randangabe?, „Kartographische Nachrichten", nr 37(2), s. 42-49.

Freitag U. (2005), Function and design of map legends in various cartographic environments, [w:] Projektowanie i redakcja map. Główne problemy 
współczesnej kartografii, red. W. Pawlak, W. Spallek, Uniwersytet Wrocławski, Pracownia Atlasu Dolnego Śląska i Zakład Kartografii Instytutu Geografii i Rozwoju Regionalnego, Wrocław, s. 48-64.

Gabbard J.L., Hix D., Swan J.E. (1999), User-centered design and evaluation of virtual environments, „IEEE Computer Graphics and Applications”, nr 19(6), s. 51-59, https://doi.org/10.1109/38.799740.

Gahegan M., Takatsuka M., Wheeler M., Hardisty F. (2002), Introducing GeoVISTA studio: An integrated suite of visualization and computational methods for exploration and knowledge construction in geography, „Computers, Environment and Urban Systems", nr 26(4), s. 267-292, https://doi.org/10.1016/ S0198-9715(01)00046-1.

Gartner G., Huang H. (2016), Recent research developments in modern cartography in Europe, „International Journal of Cartography”, nr 2(1), s. 1-5, https://doi.org/10.1080/23729333.2016.1187908.

Gog T. van, Paas F., Merriënboer J.J.G. van, Witte P. (2005), Uncovering the problem-solving process: Cued retrospective reporting versus concurrent and retrospective reporting, „Journal of Experimental Psychology: Applied”, nr 11(4), s. 237-244, https://doi.org/10.1037/1076-898X.11.4.237.

Gołębiowska I. (2010), The role of map legends in the process of map use: Conclusions from an exploratory study, „Miscellanea Geographica”, nr 14(1), s. 341-348, https://doi.org/10.2478/mgrsd-2010-0033.

Gołębiowska I. (2011), Wpływ konstrukcji legendy na proces użytkowania mapy, praca doktorska opracowana pod opieką dr. hab. J. Pasławskiego na Wydziale Geografii i Studiów Regionalnych Uniwersytetu Warszawskiego.

Gołębiowska I. (2015), Legend layouts for thematic maps: A case study integrating usability metrics with the thinking aloud method, „The Cartographic Journal”, nr 52(1), s. 28-40, https://doi.org/10.1179/1743277413Y.0000000045.

Gołębiowska I., Çöltekin A. (2020), Rainbow Dash: Intuitiveness, interpretability and memorability of the rainbow color scheme in visualization, „IEEE Transactions on Visualization and Computer Graphics", https://doi.org/10.1109/ TVCG.2020.3035823.

Gołębiowska I., Opach T., Rød J.K. (2017), For your eyes only? Evaluating a coordinated and multiple views tool with a map, a parallel coordinated plot and a table using an eye-tracking approach, „International Journal of Geographical Information Science", nr 31(2), s. 237-252, https://doi.org/10. 1080/13658816.2016.1191636.

Gołębiowska I., Opach T., Rød J.K. (2020), Breaking the eyes: How do users get started with a coordinated and multiple view geovisualization tool?, „The Cartographic Journal", nr 57(3), s. 1-14, https://doi.org/10.1080/00087041.2019. 1660513.

Goodchild M.F. (1992), Geographical Information Science, „International Journal of Geographical Information Systems", nr 6(1), s. 31-45, https://doi. org/10.1080/02693799208901893.

Gotlib D. (2008a), Nowe oblicza kartografii - aspekty metodyczne $i$ technologiczne, „Polski Przegląd Kartograficzny”, nr 40(1), s. 21-27.

Gotlib D. (2008b), Nowe oblicza kartografii - Internet a kartografia, „Polski Przegląd Kartograficzny", nr 3, s. 237-246. 
Gotlib D., Kukułka M. (2011), Metodyczne wspomaganie opracowywania geokompozycji w internetowych serwisach map i geoportalach, „Polski Przegląd Kartograficzny", nr 43(2), s. 145-154.

Göbel F., Kiefer P., Giannopoulos I., Duchowski A.T., Raubal M. (2018), Improving map reading with gaze-adaptive legends, Proceedings of the 2018 ACM Symposium on Eye Tracking Research \& Applications, s. 1-9, ACM, New York, New York, https://doi.org/10.1145/3204493.3204544.

Griffin A.L., Fabrikant S.I. (2012), More maps, more users, more devices means more cartographic challenges, „The Cartographic Journal”, nr 49(4), s. 298301, https://doi.org/10.1179/ 0008704112Z.00000000049.

Griffin A.L., Robinson A.C. (2015), Comparing color and leader line highlighting strategies in coordinated view geovisualizations, „IEEE Transactions on Visualization and Computer Graphics", nr 21(3), s. 339-349, https://doi. org/10.1109/TVCG.2014.2371858.

Griffin A.L., Robinson A.C., Roth R.E. (2017), Envisioning the future of cartographic research, „International Journal of Cartography”, nr 3 (supl. 1), s. 1-8, https://doi.org/10.1080/23729333.2017.1316466.

Harrower M., MacEachren A., Griffin A.L. (2000), Developing a geographic visualization tool to support Earth Science learning, „Cartography and Geographic Information Science", nr 27(4), s. 279-293, https://doi. org/10.1559/152304000783547759.

Havelková L., Gołębiowska I.M. (2019), What went wrong for bad solvers during thematic map analysis? Lessons learned from an eye-tracking study, "ISPRS International Journal of Geo-Information", nr 9(1), https://doi.org/10.3390/ ijgi9010009.

Hegarty M., Smallman H.S., Stull A.T., Canham M.S. (2009), Naïve cartography: How intuitions about display configuration can hurt performance, „Cartographica: The International Journal for Geographic Information and Geovisualization”, nr 44(3), s. 171-186, https://doi.org/10.3138/carto.44.3.171.

Heinrich J., Weiskopf D. (2013), State of the art of parallel coordinates, [w:] Eurographics 2013 - State of the Art Reports, red. M. Sbert, L. Szirmay-Kalos, The Eurographics Association, s. 95-116, https://doi.org/10.2312/conf/ EG2013/stars/095-116.

Holmqvist K.N., Nyström M., Andersson R., Dewhurst R., Jarodzka H., Weijer J. van de (2011), Eye tracking: A comprehensive guide to methods and measures, Oxford University Press, Oxford.

Horodyski B. (1979), Funkcjonalna analiza atlasów geograficznych, „Prace i Studia Geograficzne", nr 1, s. 87-153.

Horodyski B. (2006), Atlasy geograficzne, [w:] Wprowadzenie do kartografii i topografii, red. J. Pasławski, Wydawnictwo Nowa Era, Warszawa.

Howard D., MacEachren A.M. (1996), Interface design for geographic visualization: Tools for representing reliability, „Cartography and Geographic Information Systems", nr 23(2), s. 59-77, https://doi.org/10.1559/152304096782 562109.

Humphrey K., Underwood G. (2009), Domain knowledge moderates the influence of visual saliency in scene recognition, "British Journal of Psychology”, nr 100(2), s. 377-398, https://doi.org/10.1348/000712608X344780. 
ISO 9241-11:2018 Ergonomics of Human-System Interaction - Part 11: Usability: Definitions and Concepts.

Jacob R.J.K., Karn K.S. (2003), Eye tracking in human-computer interaction and usability research: Ready to deliver the promises, [w:] The mind's eye: Cognitive and applied aspects of eye movement research, red. J. Hyona, R. Radach, H. Deubel, Elsevier Science, Amsterdam, s. 573-605.

Jenks G.F. (1973), Visual integration in thematic mapping: Fact or fiction?, „International Yearbook of Cartography”, nr 13, s. 27-35.

Jern M., Johansson S., Johansson J., Franzen J. (2007), The GAV toolkit for multiple linked views, Fifth International Conference on Coordinated and Multiple Views in Exploratory Visualization (CMV 2007), IEEE, s. 85-97, https://doi. org/10.1109/CMV.2007.21.

Just M.A., Carpenter P.A. (1980), A theory of reading: From eye fixations to comprehension, „Psychological Review”, nr 87(4), s. 329-354, https://doi. org/10.1037/0033-295X.87.4.329.

Kaiser J. (2020), 'Every day is a new surprise': Inside the effort to produce the world's most popular coronavirus tracker, „Science”, nr 6 (April), https://doi. org/10.1126/science.abc1085.

Kałamucki K. (2005), Legenda mapy - ogniwo scalające wizję kartografa, mapę i jej użytkownika, [w:] Projektowanie i redakcja map. Główne problemy wspótczesnej kartografii, red. W. Pawlak, W. Spallek, Uniwersytet Wrocławski. Pracownia Atlasu Dolnego Śląska i Zakład Kartografii Instytutu Geografii i Rozwoju Regionalnego, Wrocław, s. 147-156.

Kang H., Plaisant C., Shneiderman B. (2003a), Helping users get started with visual interfaces: Multi-layered interfaces, integrated initial guidance and video demonstrations, Annual National Conference on Digital Government Research, Digital Government Society of North America, Boston, s. 790-794.

Kang H., Plaisant C., Shneiderman B. (2003b), New approaches to help users get started with visual interfaces: Multilayered interfaces and integrated initial guidance, Annual National Conference on Digital Government Research, Digital Government Society of North America, Boston, s. 1-6.

Keskin M., Ooms K., Dogru A.O., Maeyer P. De (2019), EEG \& eye tracking user experiments for spatial memory task on maps, „ISPRS International Journal of Geo-Information", nr 8(12), https://doi.org/10.3390/ijgi8120546.

Keskin M., Ooms K., Dogru A.O., Maeyer P. De (2020), Exploring the cognitive load of expert and novice map users using EEG and eye tracking, „ISPRS International Journal of Geo-Information", nr 9(7), https://doi.org/10.3390/ijgi9070429.

Kiefer P., Giannopoulos I., Raubal M. (2013), Using eye movements to recognize activities on cartographic maps, Proceedings of the 21st ACM SIGSPATIAL International Conference on Advances in Geographic Information Systems SIGSPATIAL'13, ACM Press, New York, New York, s. 488-491, https://doi. org/10.1145/2525314.2525467.

Kiefer P., Giannopoulos I., Raubal M., Duchowski A. (2017), Eye tracking for spatial research: Cognition, computation, challenges, „Spatial Cognition \& Computation”, nr 17(1-2), s. 1-19, https://doi.org/10.1080/13875868.2016.1254634.

Knapp L. (1995), A task analysis approach to the visualization of geographic data, [w:] Cognitive aspects of human-computer interaction for geographic 
information systems, red. T.L. Nyerges, D.M. Mark, R. Laurini, M.J. Egenhofer, Springer Netherlands, Dordrecht, s. 355-371, https://doi.org/10.1007/97894-011-0103-5_25.

Komendziński T. (1996), Znak i jego ciągłość. Semiotyka C.S. Pierce’a między precepcją a recepcją, Wydawnictwo Uniwersytetu Mikołaja Kopernika, Toruń.

Kondracki J. (red.) (1947), Mały atlas Polski, Główny Urząd Pomiarów Kraju, Warszawa.

Konopska B. (2012), Skuteczność metody zogniskowanego wywiadu grupowego w jakościowych badaniach rynku kartograficznego, „Polski Przegląd Kartograficzny", nr 44(4), s. 315-323.

Konopska B., Kamiński M. (2020), City guide as a multi-sensory mobile phone application, „Polish Cartographical Review”, nr 52(1), s. 16-26, https://doi. org/10.2478/pcr-2020-0003.

Korycka-Skorupa J., Gołębiowska I.M. (2020), Numbers on thematic maps: Helpful simplicity or too raw to be useful for map reading?, „ISPRS International Journal of Geo-Information", nr 9(7), https://doi.org/10.3390/ijgi9070415.

Koua E.L., Kraak M.-J. (2004), A usability framework for the design and evaluation of an exploratory geovisualization environment, Proceedings of the Eight International Conference on Information Visualization, IEEE, Los Alamitos, s. 153-158.

Koua E.L., Kraak M.-J. (2008), An integrated exploratory geovisualization environment based on self-organizing maps, [w:] Self-organising maps: Applications in Geographic Information Science, red. P. Agarwal, A. Skupin, John Wiley \& Sons, Ltd., Chichester, s. 45-66, https://doi.org/10.1002/9780470021699.ch3.

Koua E.L., MacEachren A., Kraak M.-J. (2006), Evaluating the usability of visualization methods in an exploratory geovisualization environment, „International Journal of Geographical Information Science", nr 20(4), s. 425-448, https:// doi.org/10.1080/13658810600607550.

Kowalski P.J. (2008), Techniczne aspekty redagowania i użytkownia serwisów geoinformacyjnych, „Polski Przegląd Kartograficzny”, nr 40(4), s. 337-348.

Kozieł Z. (2001), Geokompozycje jako ujęcia wideograficzne, „Polski Przegląd Kartograficzny", nr 33(4), s. 315-27.

Kozieł Z. (2003), Geokompozycyjno-wizualizacyjne aspekty modelowania rzeźby terenu wobec współczesnych procedur pozyskiwania i przetwarzania danych, Uniwersytet Mikołaja Kopernika, Toruń.

Kozieł Z. (2014a), Funkcjonalno-indukcyjna rola geokompozycji we współczesnym świecie multimediów, [w:] Kartografia w multimediach. Multimedia w kartografii, red. Z. Kozieł, Oddział Kartograficzny Polskiego Towarzystwa Kartograficznego, Oddział Toruński Polskiego Towarzystwa Kartograficznego, Katedra Geomatyki i Kartografii Wydziału Nauk o Ziemi UMK w Toruniu, Toruń, s. 7-16.

Kozieł Z. (red.) (2014b), Kartografia w multimediach. Multimedia w kartografii, XXXVII Ogólnopolska Konferencja Kartograficzna, Toruń, 23-24.10.2014, Oddział Kartograficzny Polskiego Towarzystwa Kartograficznego, Oddział Toruński Polskiego Towarzystwa Kartograficznego, Katedra Geomatyki i Kartografii Wydziału Nauk o Ziemi UMK w Toruniu, Toruń.

Kraak M.-J., Roth R.E., Ricker B., Kagawa A., Sourd G. Le (2020), Mapping for a sustainable world, United Nations, International Cartographic Association, New York, New York. 
Krassanakis V., Cybulski P. (2019), A review on eye movement analysis in map reading process: The status of the last decade, "Geodesy and Cartography”, nr 68(1), s. 191-209, https://doi.org/10.24425/gac.2019.126088.

Krassanakis V., Filippakopoulou V., Nakos B. (2014), EyeMMV toolbox: An eye movement post-analysis tool based on a two-step spatial dispersion threshold for fixation identification, „Journal of Eye Movement Research”, nr 7(1), https://doi.org/10.16910/jemr.7.1.1.

Krygier J. (1994), Sound and geographic visualization, [w:] Visualization in Modern Cartography, red. A.M. MacEachren, D.R.F. Taylor, Elsevier, Oxford, s. $149-166$.

Kukułka M., Gotlib D. (2014), Wpływ zjawiska neokartografii na rozwój serwisów internetowych udostępniających informacje przestrzenne, „Polski Przegląd Kartograficzny", nr 46(1), s. 34-46.

Kveladze I., Kraak M.-J., Elzakker C.P.J.M. van (2017), The usability of a GeoVisual analytics environment for the exploration and analysis of different datasets, [w:] Advances in Cartography and GIScience. Selections from the International Cartographic Conference 2017, red. M.P. Peterson, s. 207-221, https://doi.org/10.1007/978-3-319-57336-6_15.

Laramee R.S., Kosara R. (2006), Challenges and unsolved problems, [w:] Human-centered visualization environments LNCS, red. A. Kerren, A. Ebert, J. Meyer, Springer, Berlin, s. 213-254.

Li J., Chen S., Zhang K., Andrienko G., Andrienko N. (2019), COPE: Interactive exploration of co-occurrence patterns in spatial time series, „IEEE Transactions on Visualization and Computer Graphics", nr 25(8), s. 2554-2567, https:// doi.org/10.1109/TVCG.2018.2851227.

Li Z., Qin Z. (2014), Spacing and alignment rules for effective legend design, "Cartography and Geographic Information Science", nr 41(4), s. 348-362, https://doi.org/10.1080/15230406.2014.933085.

Lutyj A.A. (1981), Jazyk Karty, Znanije, Moskwa.

MacEachren A.M. (1982), The role of complexity and symbolization method in thematic map effectiveness, „Annals of the Association of American Geographers", nr 72(4), s. 495-513, https://doi.org/10.1111/j.1467-8306.1982. tb01841.x.

MacEachren A.M. (1995a), How maps work: Representation, visualization, and design, Guilford, New York.

MacEachren A.M. (1995b), Visualization in modern cartography: Setting the agenda, [w:] Visualization in Modern Cartography, red. A.M. MacEachren, D.R.F. Taylor, Elsviere Science, Oxford, s. 1-12.

MacEachren A.M., Kraak M.-J. (1997), Exploratory cartographic visualization: Advancing the agenda, „Computers \& Geosciences”, nr 23(4), s. 335-343, https://doi.org/10.1016/S0098-3004(97)00018-6.

MacEachren A.M., Kraak M.-J. (2001), Research challenges in geovisualization, „Cartography and Geographic Information Science”, nr 28(1), s. 3-12.

Majkowski J. (1989), Elektroencefalografia kliniczna, Państwowy Zakład Wydawnictw Lekarskich, Warszawa.

Makowski A. (2005), System informacji topograficznej kraju, Oficyna Wydawnicza Politechniki Warszawskiej, Warszawa. 
Manson S.M., Kne L., Dyke K.R., Shannon J., Eria S. (2012), Using eye-tracking and mouse metrics to test usability of web mapping navigation, "Cartography and Geographic Information Science”, nr 39(1), s. 48-60, https://doi. org/10.1559/1523040639148.

Marsh S.L., Dykes J., Attilakou F. (2006), Evaluating a geovisualization prototype with two approaches: Remote instructional vs. face-to-face exploratory, Tenth International Conference on Information Visualisation (IV'06), IEEE, s. 310-315, https://doi.org/10.1109/IV.2006.51.

McArdle G., Kitchin R. (2016), The Dublin dashboard: Design and development of a real-time analytical urban dashboards, „ISPRS Annals of the Photogrammetry, Remote Sensing and Spatial Information Sciences", nr IV-4/W1 (September), s. 19-25, https://doi.org/10.5194/isprs-annals-IV-4-W1-19-2016.

McGuinness C. (1994), Expert/Novice use of visualization tools, [w:] Visualization in Modern Cartography, red. A.M. MacEachren, D.R.F. Taylor, Elsevier Science Ltd., Oxford, s. 185-199.

Mead R. (2014), Expert perspectives on the design and use of learning materials for neocartographic interfaces, University of Wisconsin-Madison, Madison.

Medyńska-Gulij B. (2007a), Legenda i zasady gestaltyzmu w graficznym projektowaniu treści mapy, „Polski Przegląd Kartograficzny”, nr 37(4), s. 274-281.

Medyńska-Gulij B. (2007b), Pragmatyczne podstawy kompilowania kartograficznego, Wydawnictwo Naukowe UAM, Poznań.

Medyńska-Gulij B. (2010), Map compiling, map reading, and cartographic design in 'Pragmatic Pyramid of Thematic Mapping', "Quaestiones Geographicae”, nr 29(1), s. 57-63, https://doi.org/10.2478/v10117-010-0006-5.

Medyńska-Gulij B. (2021), Kartografia i Geomedia, Wydawnictwo Naukowe PWN, Warszawa.

Medyńska-Gulij B., Forrest D., Cybulski P. (red.) (2021), Multimedia cartography, "ISPRS International Journal of Geo-Information" (special issue).

Medyńska-Gulij B., Myszczuk M. (2012), The geovisualisation window of the temporal and spatial variability for volunteered geographic information activities, "Geodesy and Cartography", nr 61(1), s. 31-45, https://doi.org/10.2478/ v10277-012-0020-y.

Mendonça A.L. Alencar de, Delazari L.S. (2012), Remote evaluation of the execution of spatial analysis tasks with interactive web maps: A functional and quantitative approach, „The Cartographic Journal”, nr 49(1), s. 7-20, https:// doi.org/10.1179/1743277411Y.0000000020.

Moles A.A. (1971), Teoria informacji a przekaz kartograficzny, „Przegląd Zagranicznej Literatury Geograficznej", nr 1-2, s. 64-83.

Montello D.R. (2002), Cognitive map-design research in the twentieth century: Theoretical and empirical approaches, „Cartography and Geographic Information Science”, nr 29(3), s. 283-304, https://doi.org/10.1559/152304002782008503.

Montello D.R. (2009), Cognitive research in GIScience: Recent achievements and future prospects, „Geography Compass”, nr 3(5), s. 1824-1840, https://doi. org/10.1111/j.1749-8198.2009.00273.x.

Nazemi K., Burkhardt D. (2019), Visual analytical dashboards for comparative analytical tasks - a case study on mobility and transportation, „Procedia Computer Science", nr 149, s. 138-150, https://doi.org/10.1016/j.procs.2019.01.117. 
Nelson J. (2020), Multivariate mapping, [w:] The Geographic Information Science \& Technology Body of Knowlegde, red. J.P. Wilson, https://doi.org/10.22224/ gistbok/2020.1.5.

Nielsen J. (1993), Usability engineering, Academic Press, Inc., Boston.

Norman D. (1988), The design of everyday things, Doubleday, New York.

Norman D.A., Draper S.W. (1986), User-centered system design: New perspectives on human-computer interaction, Lawrence Earlbaum Associates, Hillsdale.

Ogrissek R. (1970), Kartengestaltung, Wissenspeicherung und Redundanz. Untersuchen über aktuelle Probleme im Konvergenzbereich von Kartenwissenschaft und Informatik, „Petermanns Geographischen Mitteilungen”, nr 114(1), s. 70-74.

Ogrissek R. (1983), Abc Kartenkunde, F.A. Brockhaus Verlag, Leipzig.

Ogrissek R. (1998), Redagowanie map, gromadzenie wiedzy i redundancja. Rozważania nad aktualnymi problemami w zakresie zbieżności naukowej oraz informatyki, [w:] Koncepcja mapy... Wybór tekstów, red. Z. Kozieł, Uniwersytet Mikołaja Kopernika, Toruń, s. 51-58.

Okonek M. (2000), Funkcje interaktywne w atlasach elektronicznych, „Polski Przegląd Kartograficzny", nr 32(2), s. 107-117.

Ooms K., Maeyer P. De, Fack V., Assche E. Van, Witlox F. (2012a), Interpreting maps through the eyes of expert and novice users, "International Journal of Geographical Information Science", nr 26(10), s. 1773-1788, https://doi.or g/10.1080/13658816.2011.642801.

Ooms K., Maeyer P. De, Fack V., Assche E. Van, Witlox F. (2012b), Investigating the effectiveness of an efficient label placement method using eye movement data, „The Cartographic Journal”, nr 49(3), s. 234-246, https://doi.org/10.1 179/1743277412Y.0000000010.

Opach T. (2011), Zastosowanie okulografii (techniki eye-tracking) w kartografii, „Polski Przegląd Kartograficzny”, nr 43(2), s. 155-169.

Opach T., Gołębiowska I., Fabrikant S.I. (2014), How do people view multi-component animated maps?, „The Cartographic Journal”, nr 51(4), s. 330-342, https://doi.org/10.1179/1743277413Y.0000000049.

Opach T., Rød J.K. (2013), Cartographic visualization of vulnerability to natural hazards, „Cartographica: The International Journal for Geographic Information and Geovisualization", nr 48(2), s. 113-125, https://doi.org/10.3138/ carto.48.2.1840.

Opach T., Rød J.K. (2014), Do choropleth maps linked with parallel coordinates facilitate an understanding of multivariate spatial characteristics?, "Cartography and Geographic Information Science", nr 41(5), s. 413-429, https:// doi.org/doi: 10.1080/15230406.2014.953585.

Opach T., Rød J.K. (2018), Developing a dashboard visualizing compensation data on damages caused by extreme events, "Kart og Plan”, nr 78(3), s. $207-220$.

Ostrowski W. (1970), Metakartografia - nowe spojrzenie na kartograficzną formę prezentacji, „Polski Przegląd Kartograficzny”, nr 2(2), s. 49-62.

Ostrowski W. (1974a), Sprawność kartograficznej formy przekazu, „Polski Przegląd Kartograficzny", nr 6(1), s. 14-23.

Ostrowski W. (1974b), Semantyczny aspekt sprawności mapy, „Prace i Studia Geograficzne", nr 1, s. 153-224. 
Ostrowski W. (1998), Sprawność kartograficznej formy przekazu, [w:] Koncepcja mapy... Wybór tekstów, red. Z. Kozieł, Uniwersytet Mikołaja Kopernika, Toruń, s. 64-72.

Ostrowski W. (2008), Semiotyczne podstawy projektowania map topograficznych na przykładzie prezentacji zabudowy, Uniwersytet Warszawski, Wydział Geografii i Studiów Regionalnych, Warszawa.

Ostrowski W. (2013), Relacje semiotyczne w odniesieniu do kartografii, „Polski Przegląd Kartograficzny", nr 45(1), s. 5-14.

Ostrowski W., Ostrowski J. (2014), Porównanie formy i struktury tematycznej wybranych europejskich atlasów narodowych, „Polski Przegląd Kartograficzny” nr 46(1), s. 15-33.

Ostrowski W., Pasławski J. (2006), Przedmiot kartografii i jej powiązania z innymi naukami, [w:] Wprowadzenie do kartografii i topografii, red. J. Pasławski, Wydawnictwo Nowa Era, Warszawa, s. 11-28.

Pasławski J. (red.) (2010), Wprowadzenie do kartografii i topografii, Wydawnictwo Nowa Era, Warszawa.

Pelc J. (1984), Wprowadzenie do semiotyki, Wiedza Powszechna, Warszawa.

Perkel J.M. (2020), Behind the Johns Hopkins University Coronavirus Dashboard, "Nature Index", https://www.natureindex.com/news-blog/behind-johns-hopkinsuniversity-coronavirus-dashboard, dostęp 30.07.2020.

Pernice K., Nielsen J. (2009), How to conduct eyetracking studies, Fremont, USA.

Pezanowski S., MacEachren A.M., Savelyev A., Robinson A.C. (2018), SensePlace3: A geovisual framework to analyze place-time-attribute information in social media, „Cartography and Geographic Information Science”, nr 45(5), s. 420-437, https://doi.org/10.1080/15230406.2017.1370391.

Pieniążek M., Zych M. (2017), Mapy statystyczne: opracowanie i prezentacja danych, Główny Urząd Statystyczny, Warszawa.

Plaisant C. (2005), Information visualization and the challenge of universal usability, [w:] Exploring geovisualization, red. J. Dykes, A.M. MacEachren, M.-J. Kraak, Elsevier Ltd., Amsterdam, s. 53-82.

Qin Z., Li. Z. (2017), Grouping rules for effective legend design, „The Cartographic Journal", nr 54(1), s. 36-47, https://doi.org/10.1080/00087041.2016.1148105.

Ratajski L. (1978), Główne cechy przekazu kartograficznego jako część kartografii teoretycznej, „Polski Przegląd Kartograficzny”, nr 10(3), s. 113-125.

Ratajski L. (1989), Metodyka kartografii społeczno-ekonomicznej, Państwowe Przedsiębiorstwo Wydawnictw Kartograficznych, Warszawa.

Regions and Cities Illustrated (RCl), https://ec.europa.eu/eurostat/cache/RCl/\#?vis=nuts1.population\&lang=en, dostęp 30.07.2020.

Ricker B., Kraak M.-J., Engelhardt Y. (2020), The power of visualization choices: Different images of patterns in space, [w:] Data Visualization in Society, Amsterdam University Press, Amsterdam, https://doi.org/10.5117/9789463722902_ch24.

Roberts J.C. (2007), State of the art: Coordinated \& multiple views in exploratory visualization, Proceedings of the Fifth International Conference on Coordinated and Multiple Views in Exploratory Visualization, CPS, Los Alamitos, s. 61-71.

Roberts J.C. (2008), Coordinated multiple views for exploratory geovisualization, [w:] Geographic Visualization, red. M. Dodge, M. McDerby, M. Turner, John Wiley \& Sons, Chichester, s. 25-48. 
Robinson A.C. (2011), Highlighting in geovisualization, „Cartography and Geographic Information Science", nr 38(4), s. 373-383, https://doi.org/ $10.1559 / 15230406384373$.

Robinson A. (2017), Geovisual analytics, Geographic Information Science \& Technology Body of Knowledge, red. J.P. Wilson, https://doi.org/10.22224/ gistbok/2017.3.6.

Robinson A.C., Chen J., Lengerich E.J., Meyer H.G., MacEachren A.M. (2005), Combining usability techniques to design geovisualization tools for epidemiology, "Cartography and Geographic Information Sciences”, nr 32(4), s. 243-255, https://doi.org/10.1559/152304005775194700.

Robinson A.C., Peuquet D.J., Pezanowski S., Hardisty F.A., Swedberg B. (2017a), Design and evaluation of a geovisual analytics system for uncovering patterns in spatio-temporal event data, „Cartography and Geographic Information Science”, nr 44(3), s. 216-228, https://doi.org/10.1080/15230406.2016.1139467.

Robinson A.C., Demšar U., Moore A.B., Buckley A., Jiang B., Field K., Kraak M.-J., Camboim S.P., Sluter C.R. (2017b), Geospatial big data and cartography: Research challenges and opportunities for making maps that matter, „International Journal of Cartography", nr 3 (supl. 1), s. 32-60, https://doi. org/10.1080/23729333.2016.1278151.

Roth R. (2019), How do user-centered design studies contribute to cartography?, „Geografie”, nr 124(2), s. 133-161, https://doi.org/10.37040/ geografie2019124020133.

Roth R.E. (2012), Cartographic interaction primitives: Framework and synthesis, „The Cartographic Journal”, nr 49(4), s. 376-395, https://doi.org/10.1179/ 1743277412 Y.0000000019.

Roth R.E. (2013a), Interactive maps: What we know and what we need to know, „Journal of Spatial Information Science”, nr 6 (June), s. 59-115, https://doi. org/10.5311/JOSIS.2013.6.105.

Roth R.E. (2013b), An empirically-derived taxonomy of interaction primitives for interactive cartography and geovisualization, „IEEE Transactions on Visualization and Computer Graphics", nr 19(12), s. 2356-2365, https://doi. org/10.1109/TVCG.2013.130.

Roth R.E., Çöltekin A., Delazari L., Filho H.F., Griffin A., Hall A., Korpi J. (2017), User studies in cartography: Opportunities for empirical research on interactive maps and visualizations, „International Journal of Cartography”, nr 3 (supl. 1), s. 61-89, https://doi.org/10.1080/23729333.2017.1288534.

Rød J.K., Opach T., Neset T.-S. (2015), Three core activities toward a relevant integrated vulnerability assessment: Validate, visualize, and negotiate, „Journal of Risk Research", nr 18(7), s. 877-895, https://doi.org/10.1080/13669877.2014.923027.

Saket B., Endert A., Demiralp C. (2019), Task-based effectiveness of basic visualizations, „IEEE Transactions on Visualization and Computer Graphics”, nr 25(7), s. 2505-2512, https://doi.org/10.1109/TVCG.2018.2829750.

Saliszczew K.A. (1973), Wykorzystanie map geograficznych jako narzędzia badań, „Przegląd Zagranicznej Literatury Geograficznej”, nr 3/4, s. 10-38.

Shneiderman B. (1996), The eye have it: A task by data type taxonomy for information visualization, IEEE Symposium on Visual Languages Boulder, Pictaway: IEEE Computer Society Press, s. 336-343. 
Schnürer R., Sieber R., Çöltekin A. (2015), The next generation of atlas user interfaces: A user study with 'digital natives', [w:] Modern Trends in Cartography, red. J. Brus, A. Vondrakova, V. Vozenilek, s. 23-36, https://doi.org/10.1007/978-3-319-07926-4_3. Shortridge B.G., Welch R.B. (1982), The effect of stimulus redundancy on the discrimination of town size on maps, „The American Cartographer”, nr 9(1), s. 69-78, https://doi.org/10.1559/152304082783948277.

Shoval N., Isaacson M. (2007), Sequence alignment as a method for human activity analysis in space and time, „Annals of the Association of American Geographers”, nr 97(2), s. 282-297, https://doi.org/10.1111/j.1467-8306.2007.00536.x.

Sieber R., Schmid Ch., Wiesmann S. (2005), Smart legend - smart atlas!, Proceedings of 22nd International Cartographic Conference, A Coruña.

Slingsby A., Dykes J., Wood J., Radburn R. (2014), Designing an exploratory visual interface to the results of citizen surveys, „International Journal of Geographical Information Science", nr 28(10), s. 2090-2125, https://doi.org/10. 1080/13658816.2014.920845.

Slocum T.A., Blok C., Jiang B., Koussoulakou A., Montello D.R., Fuhrmann S., Hedley N.R. (2001), Cognitive and usability issues in geovisualization, "Cartography and Geographic Information Science”, nr 28(1), s. 61-75, https:// doi.org/10.1559/152304001782173998.

Slocum T.A., Cliburn D.C., Feddema J.J., Miller J.R. (2003), Evaluating the usability of a tool for visualizing the uncertainty of the future global water balance, "Cartography and Geographic Information Science", nr 30(4), s. 299-317, https://doi.org/10.1559/152304003322606210.

Slocum T.A., McMaster R.B., Kessler F.C., Howard H.H. (2005), Thematic cartography and geographic visualization, Pearson Prentice Hall, Upper Saddle River.

Słomska K. (2021), Wpływ medium publikacji na użyteczność map, praca doktorska opracowana pod kierunkiem dr. hab. W. Ostrowskiego i I. Gołębiowskiej na Wydziale Geografii i Studiów Regionalnych Uniwersytetu Warszawskiego.

Słomska-Przech K., Gołębiowska I.M. (2020), Falling into a digital world: How are paper and interactive maps used by digital natives and immigrants?, "Geografie”, nr 125(4), s. 447-472, https://doi.org/10.37040/geografie2020125040447.

Słomska-Przech K., Gołębiowska I.M. (2021), Do different map types support map reading equally? Comparing choropleth, graduated symbols, and isoline maps for map use tasks, „ISPRS International Journal of Geo-Information”, nr 10(2), https://doi.org/10.3390/ijgi10020069.

Słownik Języka Polskiego (2020), „Redundancja”, https://sjp.pl/redundancja, dostęp 25.07.2020.

Słownik Języka Polskiego (2020), „Wiral”, https://sjp.pl/wiral, dostęp 25.07.2020.

Smallman H.S., John M.St. (2005), Naive realism: Misplaced faith in realistic displays, „Ergonomics in Design: The Quarterly of Human Factors Applications", nr 13(3), s. 6-13, https://doi.org/10.1177/106480460501300303.

Soluch P., Tarnowski A. (2013), O metodologii badań eyetrackingowych, „Lingwistyka Stosowana", nr 7, s. 115-134.

Stehle S., Kitchin R. (2020), Real-time and archival data visualisation techniques in city dashboards, „International Journal of Geographical Information Science”, nr 34(2), s. 344-366, https://doi.org/10.1080/13658816.2019.1594823. 
Steinke T.R. (1987), Eye movement studies in cartography and related fields, „Cartographica: The International Journal for Geographic Information and Geovisualization", nr 24(2), s. 40-73, https://doi.org/10.3138/J166-635U-7R56-X2L1.

Takatsuka M., Gahegan M. (2002), GeoVISTA Studio: A codeless visual programming environment for geoscientific data analysis and visualization, "Computers \& Geosciences", nr 28(10), s. 1131-1144, https://doi.org/10.1016/ S0098-3004(02)00031-6.

Tobler W.R. (1976), Analytical cartography, „The American Cartographer”, nr 3(1), s. $21-31$.

Tobón C. (2005), Evaluating geographic visualization tools and methods: An approach and experiment based upon user tasks, [w:] Exploring geovisualization, red. J. Dykes, A.M. MacEachren, M.-J. Kraak, Elsevier Ltd., Amsterdam, s. 645-666.

Tyner J.A. (2010), Principles of map design, The Guilford Press, New York.

Vasconcellos R. (1992), Knowing the Amazon through tactual maps, Proceedings of the 15th Conference of the International Cartographic Conference, International Cartographic Association, Bournemouth, s. 206-210.

Virrantaus K., Fairbairn D., Kraak M.-J. (2009), ICA research agenda on cartography and GIScience, "Cartography and Geographic Information Science”, nr 36(2), s. 209-222.

Voßkühler A., Nordmeier V., Kuchinke L., Jacobs A.M. (2008), OGAMA (Open Gaze and Mouse Analyzer): Open-source software designed to analyze eye and mouse movements in slideshow study designs, „Behavior Research Methods", nr 40(4), s. 1150-1162, https://doi.org/10.3758/BRM.40.4.1150.

Ware C. (2004), Information visualization: Perception for design, Morgan Kaufmann Publishers, San Fransisco.

Wehrend S., Lewis C. (1990), A problem-oriented classification of visualization techniques, Proceedings of the First IEEE Conference on Visualization: Visualization `90, IEEE Comput. Soc. Press, s. 139-143, https://doi.org/10.1109/ VISUAL.1990.146375.

Wikipedia, https://pl.wikipedia.org/wiki/Okulografia\#/media/Plik:Yarbus_eye_tracker. jpg, dostęp 3.09.2020.

Wilson C., Harvey A., Thompson J. (1999), ClustalG: Software for analysis of activities and sequential events, Workshop on Longitudinal Research in Social Science: A Canadian Focus, Windermere Manor, London, Ontario, Canada.

Wilson C. (2008), Activity patterns in space and time: Calculating representative Hagerstrand trajectories, „Transportation”, nr 35(4), s. 485-499, https://doi. org/10.1007/s11116-008-9162-z.

Wu X., Poorthuis A., Zurita-Milla R., Kraak M.-J. (2017), A web-based interactive platform for co-clustering spatio-temporal data, The International Archives of the Photogrammetry, Remote Sensing and Spatial Information Sciences XLII-2/W7 (September), s. 175-179, https://doi.org/10.5194/isprs-archives-XLII-2-W7-175-2017.

Wu X., Poorthuis A., Zurita-Milla R., Kraak M.-J. (2020), An interactive web-based geovisual analytics platform for co-clustering spatio-temporal data, „Computers \& Geosciences”, nr 137 (April), 104420, https://doi.org/10.1016/j. cageo.2020.104420. 
Yalcin M.A., Elmqvist N., Bederson B.B. (2018), Keshif: Rapid and expressive tabular data exploration for novices, „IEEE Transactions on Visualization and Computer Graphics", nr 24(8), s. 2339-2352, https://doi.org/10.1109/ TVCG.2017.2723393.

Yarbus A.L. (1967), Eye movements and vision, Plenum Press, New York.

Yusof N., Zurita-Milla R., Kraak M.-J., Retsios B., (2016), Interactive discovery of sequential patterns in time series of wind data, „International Journal of Geographical Information Science", nr 30(8), s. 1486-1506, https://doi.org/ 10.1080/13658816.2015.1135928.

Zabrodin W.J., Onoprienko W.I., Sołowiew W.A. (1985), Osnowy geologiczieskoj kartografii, Izdatielstwo Nauka, Nowosybirsk.

Zarycki T. (2000), Mapa w perspektywie pragmatycznej - propozycje teoretyczne, „Polski Przegląd Kartograficzny”, nr 32(2), s. 97-106.

Zarycki T. (20020, Redundancja i relewancja w komunikacji kartograficznej z perspektywy pragmatycznej, „Polski Przegląd Kartograficzny”, nr 34(1), s. 3-10.

Zastrow M. (2020), Open science takes on the coronavirus pandemic, "Nature", nr 581(7806), s. 109-110, https://doi.org/10.1038/d41586-020-01246-3.

Zhou M.X., Feiner S.K. (1998), Visual task characterization for automated visual discourse synthesis, Proceedings of the SIGCHI Conference on Human Factors in Computing Systems - CHI '98, ACM Press, New York, New York, s. 392-399, https://doi.org/10.1145/274644.274698.

Zoest W. van, Donk M., Theeuwes J. (2004), The role of stimulus-driven and goal-driven control in saccadic visual selection, „Journal of Experimental Psychology: Human Perception and Performance", nr 30(4), s. 746-759, https://doi.org/10.1037/0096-1523.30.4.749.

Zuo C., Ding L., Meng L. (2020), A feasibility study of map-based dashboard for spatiotemporal knowledge acquisition and analysis, „ISPRS International Journal of Geo-Information", nr 9(11), https://doi.org/10.3390/ijgi9110636.

Żyszkowska W. (1993), Złożoność jako właściwość obrazu kartograficznego i jej wpływ na odbiór mapy, „Polski Przegląd Kartograficzny”, nr 25(3), s. 116-125.

Żyszkowska W. (2000), Semiotyczne aspekty wizualizacji kartograficznej, Wydawnictwo Uniwersytetu Wrocławskiego, Wrocław.

Żyszkowska W. (2015), Map perception: Theories and research in the second half of the twentieth century, "Polish Cartographical Review”, nr 47(4), s. 179-190, https://doi.org/10.1515/pcr-2015-0017. 


\section{Spis rycin}

Rycina 1. Przykład zastosowania różnych form prezentacji danych na jednym arkuszu atlasowym z roku 1947 (zmniejszenie do 80\% oryginału). Źródło:

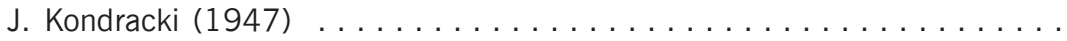

Rycina 1.1. Sześcian użytkowania mapy na podstawie A.M. MacEachrena (1995b) . . . . . . . . . . . . . . . . . . . . . . . . . . .

Rycina 1.2. Częstość użycia terminów związanych z kartografią. Źródło: A. Çöltekin i współautorzy (2017); CC BY-NC-SA $4.0 \ldots \ldots \ldots \ldots \ldots$. . . . 18

Rycina 1.3. Schemat pomiaru użyteczności według ISO 9241-11:2018 Ergonomics of Human-System Interaction - Part 11: Usability: Definitions and Concepts ............................

Rycina 1.4. Koncepcja znaku według Ch. Peirce’a, na podstawie J. Pelca (1984)

Rycina 1.5. Aspekty semiotyki kartograficznej, na podstawie W. Ostrowskiego (2008) . . . . . . . . . . . . . . . . . . . . . . . . . . .

Rycina 1.6. Zmienne graficzne wyróżnione przez J. Bertina (1967) . . . . 27

Rycina 2.1. Przykład wieloelementowego narzędzia geowizualizacji: Regions and Cities Illustrated (RCl) opracowanego dla Eurostat "Regions and Cities Illustrated (RCl)"; (C) European Union, 1995-2021; CC BY 4.0 https://

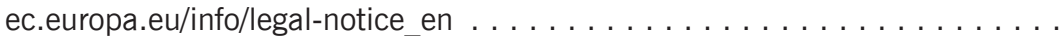

Rycina 2.2. Przykład narzędzia typu dashboard o charakterze strategicznym służącego do monitorowania postępu w zakresie realizacji celów zrównoważonego rozwoju według ONZ. Wysokość słupków prezentuje liczbę wskaźników zrównoważonego rozwoju w podziale na trzy poziomy: obrazujących cele główne (Tier I), cele operacyjne (Tier II) oraz działania (Tiering Pending) w ramach poszczególnych celów zrównoważonego rozwoju. Żródło: M.-J. Kraak i współautorzy (2020); CC BY-NC $3.0 \ldots \ldots \ldots \ldots \ldots \ldots \ldots$

Rycina 2.3. Przykład geowizualizacji wieloelementowej prezentującej te same dane (emisji dwutlenku węgla) w każdym module: kartodiagramu, wykresu oraz mapy anamorficznej. Źródło: M.-J. Kraak i współautorzy (2020); CC BY-NC 3.0 
Rycina 2.4. Umiejscowienie geowizualizacji wieloelementowych w obrębie sześcianu użytkowania mapy; opracowanie własne . . . . . . . . . .

Rycina 2.5. Różne elementy interfejsu tego samego narzędzia wieloelementowego w zależności od rodzaju operacji realizowanej przez użytkownika. Źródło: I. Dobraja i M.-J. Kraak (2020); CC BY 4.0 . . . . . . . . . . . .

Rycina 2.6. Graficzny interfejs użytkownika popularnego w 2020 roku wieloelementowego narzędzia geowizualizacji. Źródło: COVID-19 Dashboard by the Center for Systems Science and Engineering (CSSE) at Johns Hopkins University; (c) Johns Hopkins University 2020 . . . . . . . . . . . . . . .

Rycina 2.7. Aspekty (A-H) wskazane przez R.E. Rotha (2019), które mogą wzbogacić kartografię dzięki zastosowaniu badań zorientowanych na użytkownika; opracowanie własne na podstawie R.E. Roth (2019) . . . . . . .

Rycina 2.8. Narzędzie testowane przez C. Zuo, L. Ding i L. Meng (2020) prezentujące wskaźniki ekonomiczne w prowincji Jiangsu, Chiny. Kolejnymi literami oznaczono: tytuł narzędzia $(A)$, dodatkowe funkcje (B), moduł prezentujący wskaźniki w postaci map (C), moduł prezentujący zmiany wskaźników w czasie (D) oraz moduł z wartościami wskaźników prezentowanymi za pomocą wykresów słupkowych (E); CC BY $4.0 \ldots \ldots \ldots \ldots \ldots$

Rycina 2.9. Sposoby różnicowania danych źródłowych między modułami; opracowanie własne $\ldots \ldots \ldots \ldots \ldots \ldots \ldots \ldots \ldots \ldots \ldots \ldots \ldots \ldots \ldots$

Rycina 2.10. Przykłady redundancji na mapach według L. Ratajskiego (1989); opracowanie własne na podstawie L. Ratajskiego (1989) . . . . . . . . .

Rycina 2.11. Mapy animowane wykorzystane w badaniach przez P. Cybulskiego i B. Medyńską-Gulij (2018): bez redundancji (po lewej) oraz z redundancją (po prawej: mapa opracowana z wykorzystaniem prezentacji tej samej informacji za pomocą wielkości i barwy diagramów kołowych); CC BY $4.0 \ldots$. .

Rycina 2.12. Redundancja na mapach statystycznych (w dolnym rzędzie) skutkowała wyższą poprawnością i krótszym czasem odpowiedzi w porównaniu do map bez redundancji (w górnym rzędzie). Źródło: J. Korycka-Skorupa i I. Gołębiowska (2020); CC BY 4.0 . . . . . . . . . . . . . . . . . .

Rycina 2.13. Schemat budowy wykresu osi równoległych; opracowanie

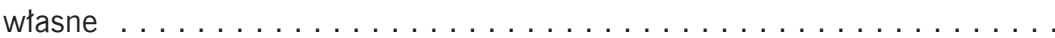

Rycina 3.1. Obszar widzenia obuocznego; opracowanie własne na podstawie P. Biecek (2016) . . . . . . . . . . . . . . . . . . . . . . . . . . . . .

Rycina 3.2. Okulograf używany $w$ połowie XX wieku. Źródło: Wikipedia: https://pl.wikipedia.org/wiki/Okulografia; CC BY-SA $3.0 \ldots \ldots \ldots \ldots \ldots$. . . .

Rycina 3.3. Przykład eye trackera stacjonarnego do testowania obrazów wyświetlanych na ekranie monitora: obecnie stosowane urządzenia są niewielkich rozmiarów (A) i umieszczane są bezpośrednio przy monitorze, np. pod ekranem (B); fotografia: J. Korycka-Skorupa, P. Kowalski . . . . . . . . .

Rycina 3.4. Wizualizacja fiksacji i sakkad w trakcie oglądania mapy opracowanej metodą kartogramu: okręgi pokazują fiksacje (im dłuższy promień koła, 
tym dłuższy czas koncentrowania wzroku w danym miejscu), linie pomiędzy fiksacjami prezentują sakkady; opracowanie własne . . . . . . . . . . . .

Rycina 3.5. Różne sposoby wizualizacji danych eye tracking; opracowanie

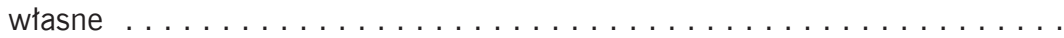

Rycina 4.1. Interfejs wieloelementowego narzędzia geowizualizacji wykorzystanego w badaniu; opracowanie własne (Gołębiowska, Opach, Rød 2017)

Rycina 4.2. Wygląd testowanego narzędzia po jego otwarciu; Źródło: T. Opach i J.K. Rød (2013), I. Gołębiowska, T. Opach, J.K. Rød (2017) . . . . . . .

Rycina 4.3. Wygląd narzędzia po zaznaczeniu linii na wykresie osi równoległych; opracowanie własne na podstawie T. Opach i J.K. Rød (2013); I. Gołębiowska, T. Opach, J.K. Rød (2017) . . . . . . . . . . . . . . . .

Rycina 4.4. Sposób wyróżnienia odpowiednich elementów po wybraniu obszaru na mapie; opracowanie własne na podstawie: T. Opach i J.K. Rød (2013); I. Gołębiowska, T. Opach, J.K. Rød (2017)

Rycina 4.5. Oznaczenie odpowiadających obiektów po wybraniu wiersza w tabeli; opracowanie własne na podstawie: T. Opach i J.K. Rød (2013); I. Gołębiowska, T. Opach, J.K. Rød (2017) . . . . . . . . . . . . . . . .

Rycina 4.6. Wybrane funkcje interaktywne testowanego narzędzia; opracowanie własne na podstawie T. Opach i J.K. Rød (2013); I. Gołębiowska, T. Opach, J.K. Rød (2017)

Rycina 4.7. Etapy badania oraz wykorzystane metody zbierania danych; opracowanie własne $\ldots \ldots \ldots \ldots \ldots \ldots \ldots \ldots \ldots \ldots \ldots \ldots \ldots \ldots \ldots$

Rycina 4.8. Ekran w części testowej badania, w którym na dole ekranu była prezentowana treść pytania, a w prawym dolnym narożniku znajdował się przycisk „Dalej” umożliwiający przejście do kolejnego polecenia; opracowanie własne (Gołębiowska, Opach, Rød 2017) . . . . . . . . . . . . . .

Rycina 5.1. Czas fiksacji w obrębie interfejsu podczas dowolnej eksploracji; opracowanie własne (Gołębiowska, Opach i Rød 2020) . . . . . . . . . . .

Rycina 5.2. Zmiana długości fiksacji i liczby sakkad w kolejnych przedziałach czasowych; opracowanie własne (Gołębiowska, Opach i Rød 2020) . . . . .

Rycina 5.3. Zakres wykorzystania funkcji interaktywnych w trakcie swobodnej eksploracji narzędzia. Czerwonym konturem słupków oznaczono funkcje realizowane poprzez odpowiednie klawisze w obrębie interfejsu; opracowanie własne (Gołębiowska, Opach i Rød 2020) . . . . . . . . . . . . . . . .

Rycina 5.4. Sposób, w jaki badani rozpoznali połączenie między modułami; opracowanie własne $\ldots \ldots \ldots \ldots \ldots \ldots \ldots \ldots \ldots \ldots \ldots \ldots \ldots \ldots \ldots$

Rycina 5.5. Różne miejsca koncentracji wzroku przez wszystkich badanych w zależności od rodzaju rozwiązywanego zadania; opracowanie własne . . .

Rycina 5.6. Różnice w długości fiksacji na poszczególne moduły w kolejnych zadaniach. Liczba gwiazdek oznacza różnice istotne statystycznie na poziomie: 
${ }^{*} p \leq 0,05, * *$ oznacza $p \leq 0,01, * * *$ oznacza $p \leq 0,001$; opracowanie

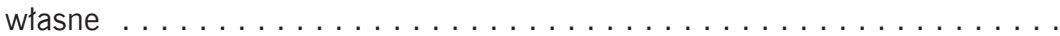

Rycina 5.7. Etapy analizy zgodności: (A) tabela porównania wyrazów „geografia” oraz „kartografia”; (B) wynik analizy dopasowania z wprowadzonymi przerwami między literami. Opracowanie własne na podstawie C. Wilson, A. Harvey i J. Thompson (1999) . . . . . . . . . . . . . . . .

Rycina 5.8. Wyniki analizy dopasowania sekwencji fiksacji z grupami użytkowników wyróżnionymi na podstawie podobieństwa. Jeden wiersz to ciąg fiksacji jednej osoby badanej; opracowanie własne (Gołębiowska, Opach

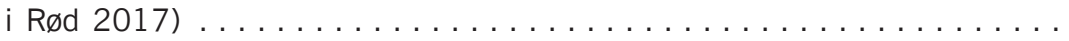

Rycina 5.9. Fiksacje na poszczególne moduły w trakcie rozwiązywania zadań różnych grup użytkowników wyróżnionych na podstawie analizy zgodności sekwencji. Im grubsza barwna linia, tym więcej badanych na danym etapie rozwiązywania zadania patrzyło na wskazany moduł; opracowanie własne (Gołębiowska, Opach i Rød 2017) . . . . . . . . . . . . . . . . . . . 100

Rycina 5.10. Moduły wykorzystane do realizacji kluczowych etapów rozwiązywania zadania; opracowanie własne (Gołębiowska, Opach i Rød 2017) . . 102

Rycina 5.11. Odsetek poprawnych odpowiedzi na poszczególne pytania; opracowanie własne (Gołębiowska, Opach i Rød 2017) . . . . . . . . . . 103

Rycina 5.12. Liczba błędów i ich przyczyny w poszczególnych zadaniach; opracowanie własne (Gołębiowska, Opach i Rød 2017) . . . . . . . . . . . 104

Rycina 5.13. Moduły wykorzystane do kluczowych etapów rozwiązywania zadań poprawnych (zaznaczonych na szaro) oraz błędnych (zaznaczonych na czerwono); opracowanie własne . . . . . . . . . . . . . . . . . . . 104

Rycina 7.1. Sposoby analizy danych eye tracking (uzupełnione innymi metodami badawczymi) z uwzględnieniem dwóch wymiarów: czasu oraz interaktywności; opracowanie własne . . . . . . . . . . . . . . 116

Rycina 7.2. Dwa wymiary geowizualizacji wieloelementowych, które użytkownik powinien poznać w celu efektywnego korzystania z nich; opracowanie

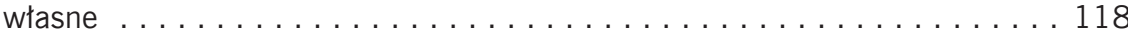

Rycina 7.3. Sześcian poznawania geowizualizacji wieloelementowej; opracowanie własne . . . . . . . . . . . . . . . . . . . . . . . . . . . . 119

Rycina 7.4. Narzędzie ClimRes przed zmianą legendy symbolizacji i legendy interaktywności (Opach i Rød 2018) . . . . . . . . . . . . . . . . . . 124

Rycina 7.5. Interfejs wieloelementowego narzędzia geowizualizacji po przeprojektowaniu: z jedną legendą odnoszącą się do wszystkich modułów . . . 124 


\section{Spis tabel}

Tabela 4.1. Zadania realizowane w części testowej (przetłumaczone na język polski) (klasyfikacja zadań za: Amar, Eagan, Stasko, 2005; treść zadań za: Gołębiowska, Opach i Rød, 2017) . . . . . . . . . . . . 78

Tabela 5.1. Czas do pierwszej fiksacji oraz długość fiksacji na poszczególnych modułach testowanego narzędzia (* oznacza różnice statystyczne na poziomie $p<0,05)$; opracowanie własne (Gołębiowska, Opach i Rød 2020) . . . . .

Tabela 5.2. Rozkład uwagi wizualnej przed zorientowaniem się przez badanych o połączeniu między modułami i po zorientowaniu się o tym; opracowanie własne (Gołębiowska, Opach i Rød 2020) . . . . . . . . . . . . . . 93

Tabela 5.3. Średni czas fiksacji na modułach w poszczególnych zadaniach; opracowanie własne (Gołębiowska, Opach i Rød 2017) . . . . . . . . . . . 94

Tabela 6.1. Wskazówki dotyczące treści materiałów szkoleniowych przeznaczonych dla początkujących użytkowników geowizualizacji wieloelementowych; opracowanie własne (Gołębiowska, Opach i Rød 2020) . . . . . . . . . . 110 


\section{Summary}

Cartography, as a scientific and practical domain, has been undergoing intensive changes for several decades because of dynamic technological developments. Due to new means of expression and available solutions, opportunities have been created but problems and challenges have also arisen. An example of a solution that has resulted from technological developments is and a new approach to working with spatial information is coordinated and multiple views (CMV) tool. This consist of several views, presented simultaneously and connected interactively. Each view presents (spatial) data in a different way, and this includes maps, graphs, diagrams and spreadsheets. Such tools are considered by some authors to be one of the most promising geovisual solutions, although there are also opinions on their low usefulness.

CMV represents a huge potential for the effective exploration of large and complex data sets, but like any new tool, it needs to be appropriately assessed. Among other things, its critics have pointed to the problem of its limited use, so understanding how new users learn to use this type of tool, and how they can be helped, seems to be of high importance for its popularization.

This study aims to relate the investigation of CMV with cartographic semiotics, for which important design issues include: selecting input data; explaining the meaning of signs in the legend - which is particularly relevant to semantics; and getting users to understand the presented data via CMV - the subject of pragmatics. The cognitive aim of this research is to assess the usefulness of redundancy (presenting the same input data in various views) in CMV. The methodological aim of the study is to develop the methodology of eye tracking data analysis in the empirical study of CMV tools; in particular, to identify new areas of application of the eye tracking method, thus expanding its potential. The practical aim is to investigate the process of inexperienced users learning 
an unknown CMV tool. On this basis, guidelines have been formulated for designers of this type of tool, and its training and tutorial materials.

To achieve the goals, theoretical considerations in the field of cartography and related disciplines were taken into account; then empirical research was conducted. This allowed for the formulation of conclusions of both a practical and theoretical nature. As the context of cartographic semiotics was considered, general conclusions were formulated, allowing for dimensions to be distinguished to help design CMV tool interfaces. The set of methods of data collection applied - eye tracking, interaction logs, thinking aloud, and response accuracy - allowed for the collection of diverse data and an analysis of the process of working with CMV geovisualization tools from many angles and, therefore, for the formulation of conclusions.

Consequently, the effects and goals achieved include not only organizing the existing knowledge, but - thanks to its theoretical basis - formulating new synthetic approaches. The result of the work is a model of learning a CMV tool, which is the basis of an extended approach to legends in such tools. Apart from traditionally understood symbols, the legend of a CMV tool can cover interactive elements of the layout. Another result of the study that was achieved through conducting empirical research, among other things, is the proposal of a new approach to the analysis of data obtained using the eye tracking method. In the applied approach, two dimensions of applied analysis are distinguished: including interactivity (or not); and applying temporal information with regard to eye tracking data. Moreover, the conducted empirical studies allow for the assessment of the usefulness of a CMV tool for inexperienced users and the formulation of recommendations for designers of this type of tool. Such empirically proven clues are valuable because during their design work, the authors of CMV geovisualizations can choose from many solutions that only seemingly can be of similar utility.

The work consists of eight chapters. In the opening chapter, I outline the current place of cartography in the context of several related scientific disciplines. I also emphasize the role of semiotics in cartography; in particular, I draw attention to the possibility of using cartographic semiotics in the design and analysis of CMV geovisualization research. In the next chapter, I introduce the concept of CMV geovisualizations, and point to problems related to their design. In chapter three, I deal with the need for usability research in cartography and geovisualization, with particular emphasis on those that apply the eye tracking method. Another three chapters contain a description and analysis of the empirical research I conducted, and aim to verify theoretical considerations and 
answer the research questions posed. At their center, I put the process of learning an unknown CMV and the usefulness of redundancy in such tools. In the course of the conducted analyses, emphasis has been put on cartographic semantics. Due to the research being conducted with users of CMV, the pragmatic aspect of these analyses is of particular importance. In turn, in chapter seven, I presented conclusions formulated in a new context based on the obtained results and analyses. This made it possible to formulate an extended approach to the legend of the CMV geovisualizations and to propose a model of learning this kind of tools. The work ends with a summary in which I assess the importance of cartography as a discipline in the study of CMV geovisualization tools, and point to the need for further research.

Keywords: coordinated and multiple views; CMV; cartographic semiotic; user study; eye tracking; cartography; geovisualization

Słowa kluczowe: geowizualizacje wieloelementowe; semiotyka kartograficzna; badania użyteczności; eye tracking; kartografia; geowizualizacja 


\section{Indeks nazwisk}

Indeksem objęto tekst główny wraz z przedmową, posłowiem i przypisami. Gwiazdkami oznaczono numery stron, na których osoby występują wyłącznie w podpisach do ilustracji, kursywą oznaczono numery stron, na których osoby występują wyłącznie w przypisach.

Amar Robert 77, 78, 90

Andrienko Gennady 7, 10, 16, 22, 23, $34,37,40,52-54,65,74,101$, 107, 115, 117

Andrienko Natalia 7, 10, 16, 22, 23, $34,37,40,52-54,65,74,101$, $107,115,117$

Antes James 65

Asłanikaszwili Aleksander Fiodorowicz 24

Attilakou Fenia 40

Auer Eric 92

Baldonado Michelle Q. Wang 29, 37, 38, 50, 53, 107, 111

Bederson Benjamin B. 41

Behrens Jan 79

Berlant Aleksander M. 9, 20

Bertin Jacques 8, 25, 26, 27*, 28, 47, 120

Bhowmick Tanuka 40, 41

Biecek Przemysław 57

Bishop Ian D. 33, 40

Blascheck Tanja 61, 62, 65, 117

Borji Ali 60, 76

Bouissac Paul 25

Brewer Cynthia A. 11
Burkhardt Dirk 10, 41

Buttenfield Barbara 79

Carpenter Patricia A. 59

Castner Henry W. 65

Chang Kang-Tsung 65

Chi Michelene T.H. 79

Çöltekin Arzu 12, 13, 16, 17, 18*, $22,23,30,33,34,39,60,64$, 65, 75, 118, 122

Convertino Gregorio 43, 51

Cybulski Paweł 48, 65

Czerny Andrzej 9

Deitrick Stephanie 108

Delazari Luciene 49

Demiralp Çağatay 68

Demšar Urška 40, 76

DiBiase David 16, 27

Ding Linfang 30, 40, 41, 42*, 107

Dobraja leva 34, 35*

Dobson Michael W. 48, 65, 76

Dolezalova Jitka 63

Dong Ensheng 36, 81, 127

Dong Weihua 59, 65, 81

Donk Mieke 60

Draper Stephen W. 38 
Du Hongru 36, 127

Duchowski Andrew T. 58, 59

Dukaczewski Dariusz 27

Dupont Lien 76, 79

Dykes Jason A. 16, 32, 40

Eagan James 77, 78, 90

Eastman Ronald J. 65

Edler Dennis 121

Edsall Robert M. 33, 43, 51, 53, 68, 77, 108, 112, 113

Elmqvist Niklas 41

Elzakker Corné P. J. M. van 43, 79

Endert Alex 68

Engelhardt Yuri 32, 34

Ericsson K. Anders 79

Fabrikant Sara Irina 12, 16, 17, 34, 38, 64, 65, 76, 97, 114, 115

Fairbairn David 22

Feiner Steven K. 39

Ferrara John 54

Filippakopoulou Vassiliki 60

Freitag Ulrich 25, 120, 121

Gabbard Joseph L. 38

Gahegan Mark 33

Gardner Lauren 36, 127

Gartner Georg 15, 22

Giannopoulos Ioannis 60

Göbel Fabian 121

Gog Tamara van 81

Gołębiowska Izabela 12, 13, 19, 23, 26, 28, 49, 65, 67, 76, 79, 97, $114,115,120,121$

Goodchild Michael F. 17

Gotlib Dariusz 20, 22

Griffin Amy L. 15, 16, 22, 30, 32, 38, 53, 55, 56

Harrower Mark 53

Harvey Andrew S. 97, 98*

Havelková Lenka 12, 65, 114

Hegarty Mary 51, 65

Heinrich Julian 90, 108

Hix Deborah 38

Holmqvist Kenneth N. 60
Horodyski Bogdan 121

Howard David 79

Huang Haosheng 15, 22

Humphrey Katherine 76

Isaacson Michal 97

Itti Laurent 60, 76

Jacob Robert J. K. 102

Janetzko Halldór 16, 17, 34

Jenks George F. 65

Jern Mikael 34

John Mark St. 51

Just Marcel A. 59

Kaiser Jocelyn 36

Kałamucki Krzysztof 28, 120

Kamiński Mateusz 9

Kang Hyunmo 54

Karn Keith S. 102

Keskin Merve 66

Kiefer Peter 56, 58, 60, 65

Kitchin Rob 30

Knapp Loey 36

Komendziński Tomasz 25

Kondracki Jerzy 8*

Konopska Beata 9, 64

Korycka-Skorupa Jolanta 12, 49

Kosara Robert 22

Koua Etien L. 7, 29, 39, 43, 68, 75, 77, 112

Kowalski Paweł J. 20

Kozieł Zenon 9

Kraak Menno-Jan 7, 16, 22, 29, 30, $31^{*}, 32,34,35^{*}, 39,43,68,75$, 77, 112, 117

Krassanakis Vassilios 63, 65

Krygier John B. 27

Kuchinsky Allan 29, 37, 38, 50, 53, 107, 111

Kukułka Michał 20, 22

Kveladze Irma 43

Laramee Robert S. 22

Lenzen Thomas 65

Lewis Clayton 41

Li Jie 40, 41 
Li Zhilin 121, 122

Lutyj Aleksander Aleksiejewicz 120

MacEachren Alan M. 7, 16, 17, 22, 26, 27, 29, 39, 43, 49, 53, 68, 75, 77, 79, 112, 117, 120

Majkowski Jerzy 66

Makowski Andrzej 15

Manson Steven M. 89

Marsh Stephanie Larissa 40

McArdle Gavin 30

McGuinness Carol 52

Mead Rashauna 53, 54

Medyńska-Gulij Beata 15, 28, 34, 48, 64, 122

Mendonça André Luiz Alencar de 49

Meng Liqiu 30, 40-42, 107

Moles Abraham A. 45

Montello Daniel R. 22, 56, 65

Morris Charles W. 25

Myszczuk Miłosz 34

Nakos Byron 63

Nazemi Kawa 10, 41

Nelson John 47

Neset Tina-Simone 70

Nielsen Jakob 23, 53, 54, 64, 75

Norman Donald A. 38

Ogrissek Rudi 45, 46

Okonek Michał 19

Onoprienko Valentin Iwanowich 25

Ooms Kristien 59, 65

Opach Tomasz 12, 43, 51, 53, 64, $65,67,70,76,83,97,114$, 115,123

Ostrowski Jerzy 8

Ostrowski Wiesław 8-10, 15, 21 , 24-26, 28

Pasławski Jacek 15, 121

Peirce Charles Sanders 24, 25

Pelc Jerzy 24, 25*

Perkel Jeffrey M. 36

Pernice Kara 64, 75

Pezanowski Scott 10, 40, 41

Pieniążek Marek 121
Plaisant Catherine 54, 107

Popelka Stanislav 63

Qin Zhe 121, 122

Ratajski Lech 24, 45-47

Raubal Martin M. 60

Rebich-Hespanha Stacy 65

Ricker Britta 32

Roberts Jonathan C. 7, 29, 32, 33, 44, 45, 52, 107, 111

Robinson Anthony C. 10, 15, 16, 18, 22, 30, 32, 39-41, 51, 53, 55, 56,79

Rød Jan Ketil 12, 43, 51, 53, 67, 70, 123

Roth Robert E. 15, 19, 20, 22, 32 , $39,40 *, 55,56,77$

Saket Bahador 68

Saliszczew Konstantin Aleksiejewicz 18

Schmid Christoph 120

Schmidt Manuela 79

Schnürer Raimund 122

Shneiderman Ben 54, 107

Shortridge Barbara G. 49

Shoval Noam 97

Sieber René 120, 122

Sihite Dicky N. 60, 76

Simon Herbert A. 79

Slingsby Aidan 45, 54

Slocum Terry A. 38, 47, 56, 121

Słomska Katarzyna zob. Słomska-Przech Katarzyna

Słomska-Przech Katarzyna 12, 13, 19, 81

Smallman Harvey S. 51

Soluch Paweł 57, 59

Sołowiew Władimir 25

Stasko John 77, 78, 90

Stehle Samuel 30

Steinke Theodore R. 65

Swan J. Edward 38

Takatsuka Masahiro 33

Tarnowski Adam 57, 59

Theeuwes Jan 60 
Thompson Julie 97, 98* Tobler Waldo R. 18

Tobón Carolina 77

Tyner Judith A. 46, 47

Underwood Geoffrey 76

Vasconcellos Regina 27

Virrantaus Kirsi 22

Voßkühler Adrian 63

Ware Colin 47

Wehrend Stephen 41

Weiskopf Daniel 90, 108

Welch Robert B. 49

Wiesmann Samuel 120

Wilson Clarke 83, 97, 98*
Woodruff Allison 29, 37, 38, 50, 53, 107, 111

Wu Xiaojing 34

Yalçın Mehmet Adil 41

Yarbus Alfred L. 76

Yusof Norhakim 34

Zabrodin Władimir Jurievich 25

Zarycki Tomasz 47, 115

Zastrow Mark 36

Zhou Michelle X. 39

Zoest Wieske van 60

Zuo Chenyu 30, 40, 41, 42*, 107

Zych Maciej 121

Żyszkowska Wiesława 28, 37, 56 
Publikacja poświęcona jest geowizualizacjom wieloelementowym, czyli interaktywnym opracowaniom składającym się z kilku modułów prezentujących dane przestrzenne za pomocą różnych form, w tym map. Praca obejmuje zarówno rozważania teoretyczne, jak i badania empiryczne z wykorzystaniem metody eye tracking. Celem Autorki było m.in. określenie sposobu wykorzystania geowizualizacji wieloelementowych przez niedoświadczonych użytkowników i sformułowanie na tej podstawie wskazówek dla osób projektujących takie opracowania oraz przygotowujących materiały szkoleniowe do pracy z podobnymi rozwiązaniami.

Publikacja polecana jest badaczom z zakresu kartografii i geowizualizacji oraz studentom kierunków geograficznych, w szczególności specjalizacji kartograficznej i geoinformatycznej, a także adeptom nauk społecznych i humanistycznych zainteresowanym klarowną prezentacją bogatych danych przestrzennych. Może również znaleźć odbiorców wśród praktyków - specjalistów różnych dziedzin, poszukujących najlepszych rozwiązań umożliwiających jednoczesną prezentację kilku powiązanych ze sobą informacji.

Zastosowane przez Autorkę metody i narzędzia sytuują tę pracę w czołówce badań kartograficznych prowadzonych w Polsce i pokazują, w jak różny sposób możemy badać mapy główny przedmiot zainteresowania kartografów.

z recenzji dr hab. Beaty Konopskiej, prof. UMCS

W polskiej literaturze kartograficznej jest to praca zdecydowanie nowatorska [...]. Należy podkreślić szerokie omówienie podstaw teoretycznych, łączących kartografię, geowizualizację i GIScience, oraz wyczerpującą charakterystykę geowizualizacji wieloelementowych, które są podstawowym przedmiotem badań eksperymentalnych [...], a także zastosowań metody eye tracking, rejestru interakcji oraz protokotów głośnego myślenia.

z recenzji dr hab. Wiesławy Żyszkowskiej, prof. emeryt. UWr

Izabela Gołębiowska - doktor nauk o Ziemi w zakresie geografii, kartograf, pracownik naukowy Wydziału Geografii i Studiów Regionalnych Uniwersytetu Warszawskiego. Zastępca redaktora naczelnego czasopisma „Miscellanea Geographica - Regional Studies on Development”, laureatka stypendium Ministerstwa Nauki i Szkolnictwa Wyższego, nagrody Rektora Uniwersytetu Warszawskiego i innych nagród. Kierownik projektów badawczych finansowanych przez Narodowe Centrum Nauki oraz Research Council of Norway. Jej zainteresowania naukowe obejmują poznawcze aspekty czytania i analizy informacji przestrzennych z map. Zagadnienia te eksploruje, między innymi prowadząc badania z użytkownikami map i opracowań kartograficznych. Badania te służą optymalizacji redakcji map i różnego typu geowizualizacji poprzez dostosowanie do potrzeb oraz możliwości ich użytkowników. 